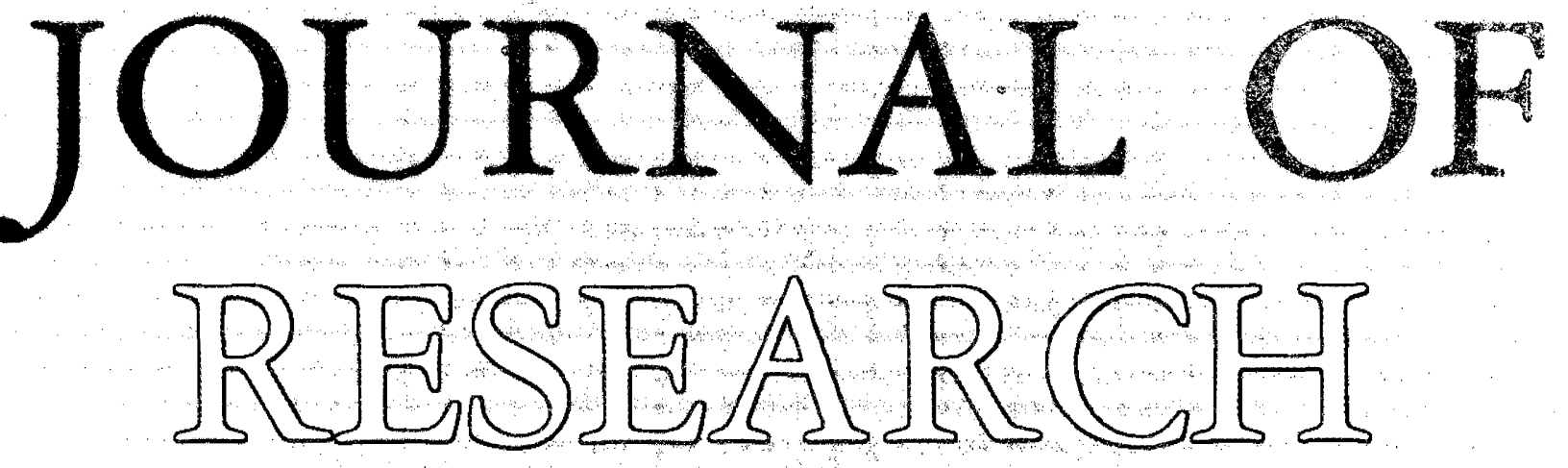

\title{
OF THE U.S. GEOLOGICAL SURVEY
}

JANUARY-FEBRUARY 1976 .

VOLUME 4, NUMBER 1

\author{
Teohnical Information office automatig \\ distriburion
}

Scientific notes and summaries of investigations in geology, bydrology, and related fields

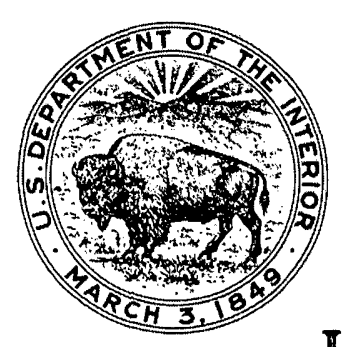

U.S. DEPARTMENT OF THE INTERIOR 


\title{
UNITED STATES DEPARTMENT OF THE INTERIOR
}

\section{THOMAS S. KLEPPE, Secretary}

GEOLOGICAL SURVEY

\author{
V. E. McKelvey, Director
}

For sale by the Superintendent of Documents, U.S. Government Printing Office, Washington, DC 20402. Annual subscription rate $\$ 18.90$ (plus $\$ 4.75$ for foreign mailing). Single copy $\$ 3.15$. Make checks or money orders payable to the Superintendent of Documents.

Send all subscription inquiries and address changes to the Superintendent of Documents at the above address.

Purchase orders should not be sent to the U.S. Geological Survey library.

Library of Congress Catalogcard No. 72-600241.
The Journal of Research is published every 2 months by the U.S. Geological Survey. It contains papers by members of the Geological Survey and their professional colleagues on geologic, hydrologic, topographic, and other scientific and technical subjects.
Correspondence and inquiries concerning the Journal (other than subscription inquiries and address changes) should be directed to Anna $\mathbf{M}$. Orellana, Managing Editor, Journal of Research, Publications Division, U.S. Geological Survey, National Center 321, Reston, VA 22092.

Papers for the Journal should be submitted through regular Division publication channels.

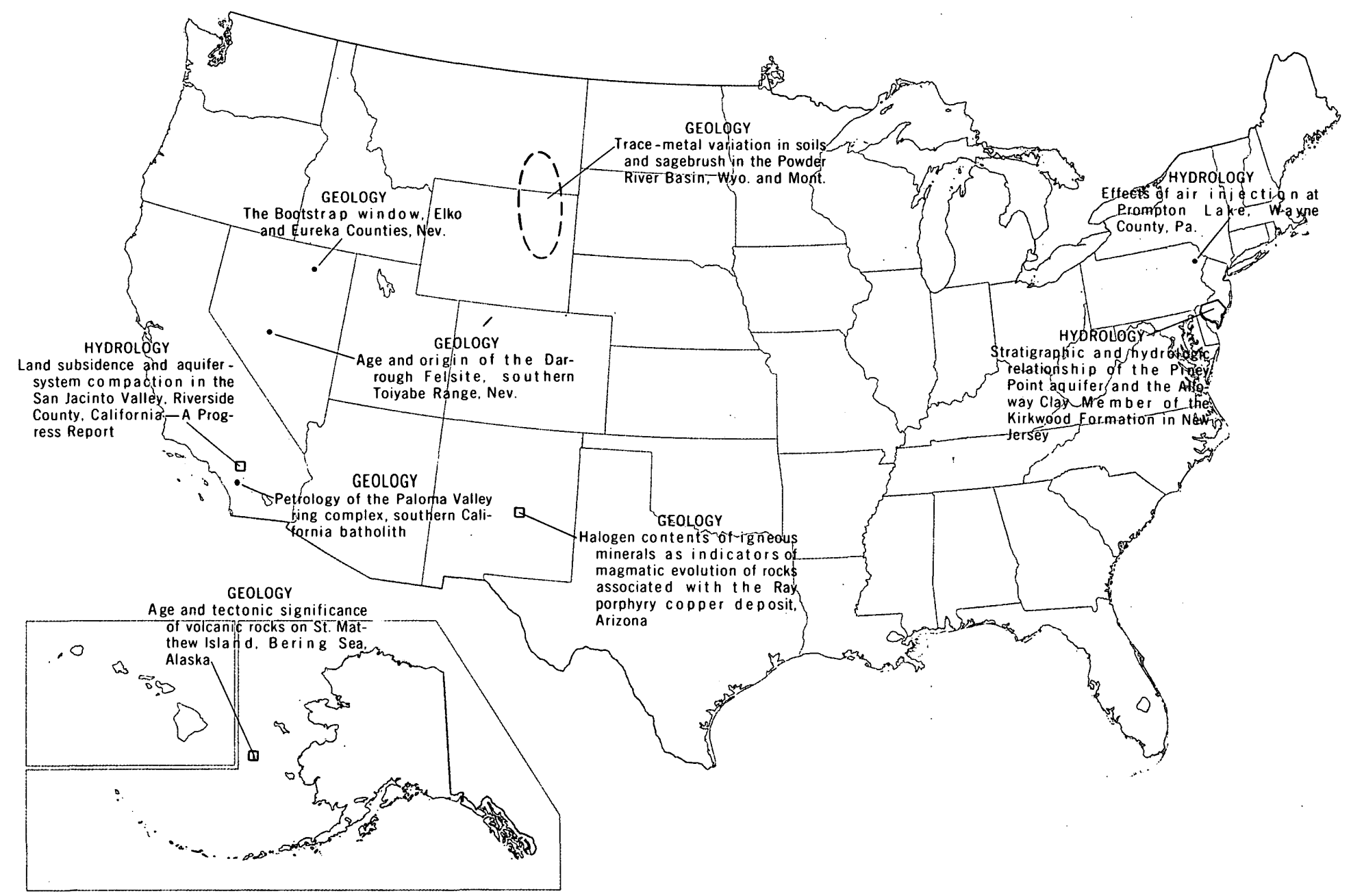

The Secretary of the Interior has determined that the publication of this periodical is necessary in the transaction of the public business required by law of this Department. Use of funds for printing this periodical has been approved by the Director of the Office of Management and Budget through June 30, 1980.

\section{GEOGRAPHIC INDEX TO ARTICLES}

See "Contents" for articles concerning areas outside the United States and articles without geographic orientation. 


\title{
JOURNAL OF RESEARCH
}

\author{
of the
}

U.S. Geological Survey

Vol. 4 No. 1

Jan.-Feb. 1976

\section{CONTENTS}

Abbreviations.

II

Metric-English equivalents

\section{HYDROLOGIC STUDIES}

Stratigraphic and hydrologic relationship of the Piney Point aquifer and the Alloway Clay Member of the Kirkwood Formation in New Jersey________Bronius Nemickas and L. D. Carswell Land subsidence and aquifer-system compaction in the San Jacinto Valley, Riverside County, California-A progress report._._. Effects of air injection at Prompton Lake, Wayne County, Pa_._-

\section{GEOLOGIC STUDIES}

Exploration for porphyry copper deposits in Pakistan using digital processing of Landsat-1 data A A portable helium sniffer._._._._. Denton Method and importance of obtaining humic and fulvic acids of high purity_-_._. $R$. L. Malcolm Behavior of trace elements during magmatic processes-A summary of theoretical models and their application._._.

Trace-metal variation in soils and sagebrush in the Powder River Basin, Wyo. and Mont source of hydrothermal solutions at Puerto Maunabo and its hearing on the base-metal-potassium feldspar association in Puerto Rico.. Pease, Jr.

Age and tectonic significance of volcanic rocks on St. Matthew Island, Bering Sea, Alaska...-W. W. Patton, Jr., M. A. Lanphere, T. P. Miller, and R. A. Scott

Age and origin of the Darrough Felsite, southern Toiyabe Range, Nev

R. C. Specd and E. H. McKee

Petrology of the Paloma Valley ring complex, southern California batholith D. M. Morton and A. K. Baird

Halogen contents of igneous minerals as indicators of magmatic evolution of rocks associated with the Ray porphyry copper deposits, Arizona__ The Bootstrap window, Elko and Eureka Counties, Nev______J. G. Evans and T. E. Mullens 


\section{ABBREVIATIONS}
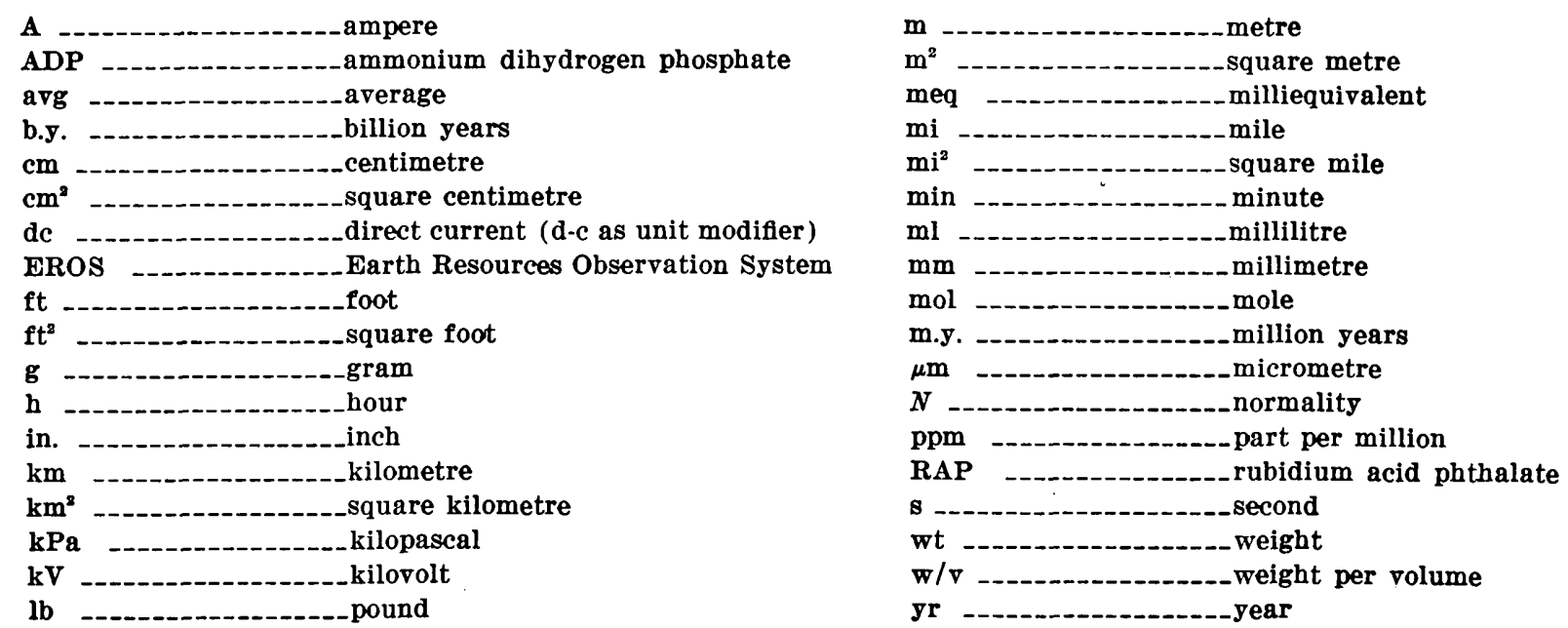

METRIC-ENGLISH EQUIVALENTS

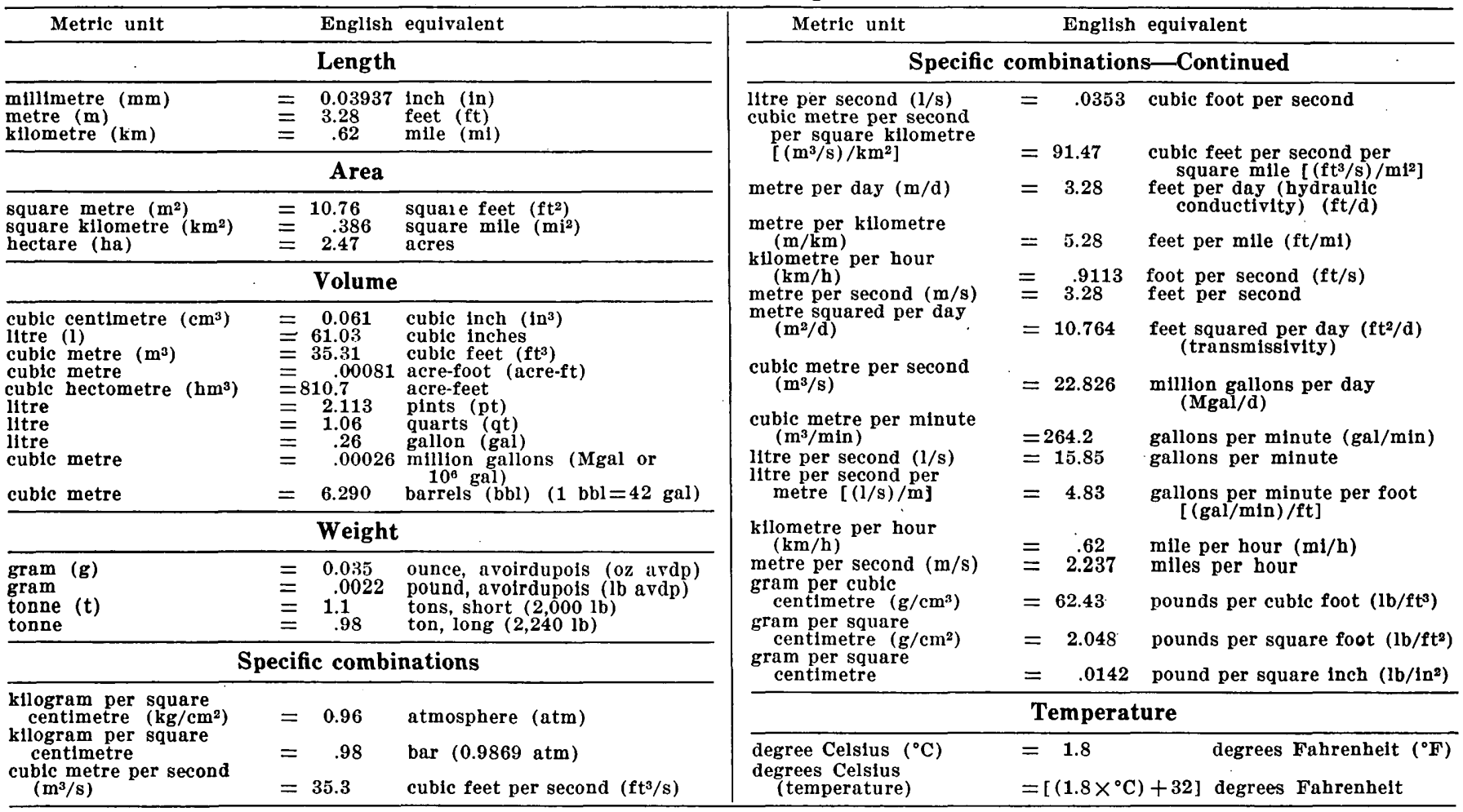

Any use of trade names and trademarks in this publication is for descriptive purposes - only and does not constitute endorsement by the U.S. Geological Survey.

II 
Jour. Research U.S. Geol. Survey
Vol. 4, No. 1, Jan.-Feb. 1976, p. 1-7

\title{
STRATIGRAPHIC AND HYDROLOGIC RELATIONSHIP OF THE PINEY POINT AQUIFER AND THE ALLOWAY CLAY MEMBER OF THE KIRKWOOD FORMATION IN NEW JERSEY
}

\author{
BY BRONIUS NEMICKAS and LOUIS D. CARSWELL, \\ Trenton, N.J., Harrisburg, Pa.
}

\begin{abstract}
Coarse quartzose (clastic) sediments of middle and late Eocene age in the subsurface of southern New Jersey are identified in this report as the Piney Point aquifer. The sediments are as thick as 220 feet $(67$ metres) and form a freshwater aquifer which is laterally continuous with the Piney Point aquifer of the Delmarva Peninsula. The Piney Point aquifer, in the area of Newport in Cumberland County, consists of fine to coarse glauconitic sand that is suggestive of deposition in a marginal marine beach environment. The aquifer tends to become finer grained with depth; coarse sand is dominant near the top of the aquifer, whereas, silt and clay are dominant near the base. The top of the aquifer-is marked by an angular unconformity. The hiatus between the upper Eocene sediments and the overlying Kirkwood Formation of middle Miocene age represents erosion during oligocene and early Miocene time. The Alloway Clay Member, the basal unit of the Kirkwood Formation, rests unconformably on the Piney Point aquifer. It is a silty clay, dark brown to light tan, and contains abundant shell fragments and reworked greensand from the underlying Piney Point aquifer. The Alloway Clay Member, where present, acts as a confining unit for the Piney Point aquifer in southern New Jersey. Chemical analyses of water samples from the Piney Point aquifer in Cumberland County indicate a potential chloride problem in the aquifer near Delaware Bay. A water sample taken in 1973 at the Gandys Beach well contained 516 milligrams per litre of chloride, and a water sample taken in 1973 at the Money Island Marina well contained 73 miligrams per litre of chloride. Scant water-level data indicate the possibility of declining water levels in Cumberland County near Delaware Bay due to pumping from the Piney Point aquifer in Delaware. The altitude of the water level at well 16 is -3 feet $(-1$ metre), and the water-level altitude at well 11 is +23 feet ( +7 metres).
\end{abstract}

Marine sediments of late Eocene age, which are correlated with the Jackson Group of the Gulf Coast, have been recognized in the subsurface in Delaware and southern New Jersey (Richards, 1956, p. 84). The glauconitic sand and interspersed shell beds of southern Maryland were named the Piney Point Formation (Otton, 1955, p. 85) from a well at Piney Point, St.
Mary's County. Brown, Miller, and Swain (1972) reexamined the sediments from the Piney Point type section and found the formation to be of Claiborne age rather than Jackson age. Rasmussen, Slaughter, Hulme, and Murphy (1957, p. 61-67), on the basis of microfossils, lithology, and well logs, extended the name Piney Point to a unit on the eastern shore of Maryland. Rasmussen, Groot, and Depman (1958) extended the name to a fossiliferous, glauconitic sand and clay unit penetrated in a test well at Dover Air Force Base, Del.

Test drilling by the U.S. Geological Survey, in cooperation with the Cumberland County Planning Board, in the fall of 1971 and spring and summer of 1972 helped to establish an observation-well network in Cumberland County (fig. 1). The data collected during this drilling aided in defining the stratigraphic and hydrologic relationship between the Piney Point aquifer and the overlying Alloway Clay Member of the Kirkwood Formation. The Piney Point aquifer is defined in this paper as the upper sandy part of the Eocene sediments that is laterally continuous with the Piney Point aquifer in Delaware.

\section{PINEY POINT AQUIFER}

The Piney Point aquifer consists of fine to coarse glauconitic sand. It occurs in the upper part of the Piney Point (?) Formation in Gloucester and Atlantic Counties but constitutes the entire Piney Point (?) Formation in Cumberland County (Nemickas, 1974). The thickness of the aquifer ranges from $26 \mathrm{ft}(7.9 \mathrm{~m})$ to more than $220 \mathrm{ft}(66.8 \mathrm{~m})$ in Cumberland County (fig. 2). Structure contours on top of the aquifer in figure 3 indicate a fairly consistent dip of 20 to 25 $\mathrm{ft} / \mathrm{mi}(9.8-12.2 \mathrm{~m} / \mathrm{km})$ to the southeast.

The Piney Point aquifer in the Delmarva Peninsula overlies the Nanjemoy Formation and is overlain by 


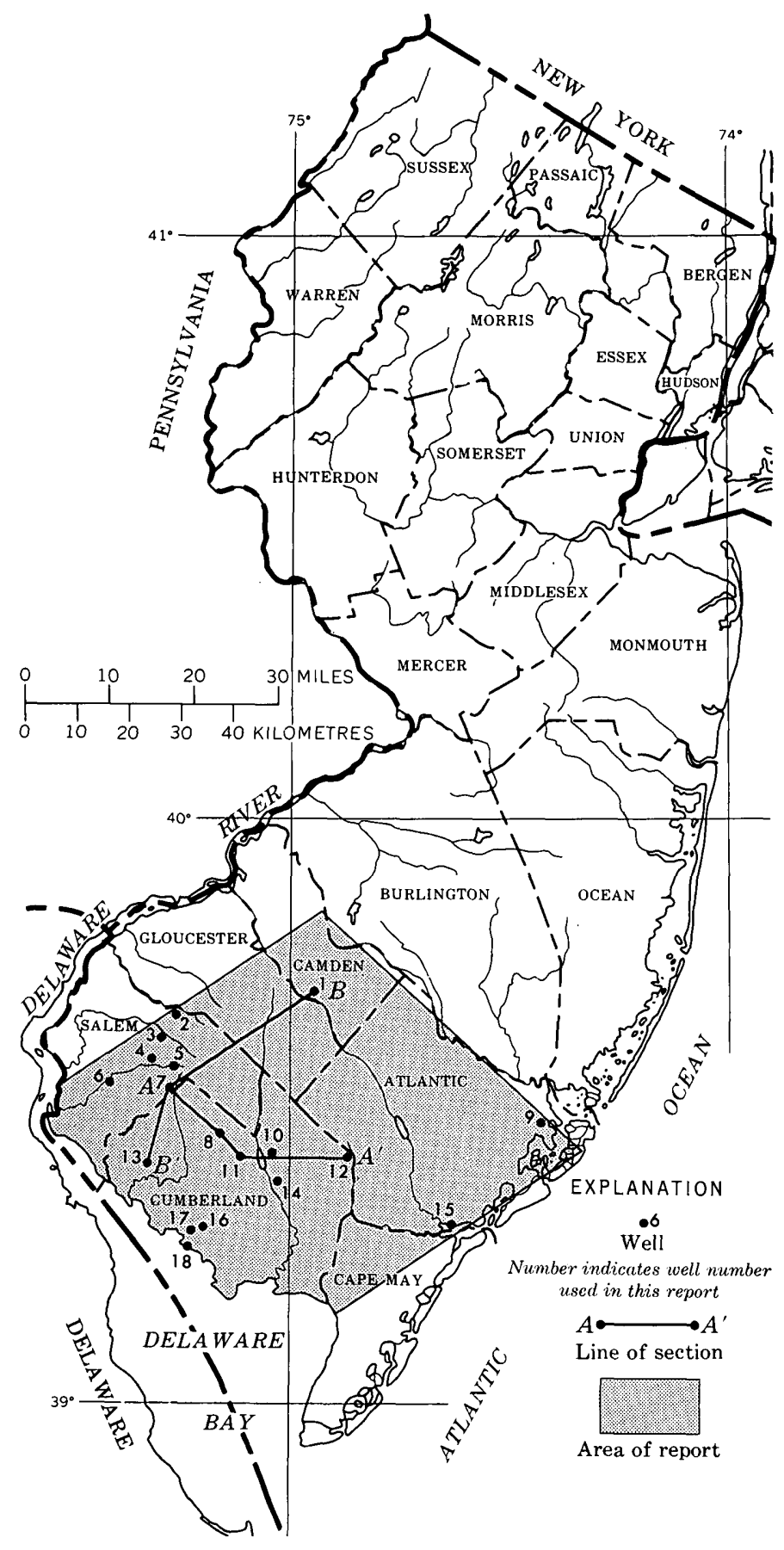

Figure 1.-Map of New Jersey showing location of study area.

the Calvert Formation (Cushing and others, 1973). Its thickness in the Delmarva Peninsula ranges from 20 to $270 \mathrm{ft}(6.1-82.3 \mathrm{~m})$. "The upper part seems to be the most productive, as geophysical logs indicate that the aquifer becomes progressively more silty or clayey in the lower part" (Cushing and others, 1973, p. 42). The same relationship can be seen on geophysical logs and samples collected at drilling sites in southern New Jersey.

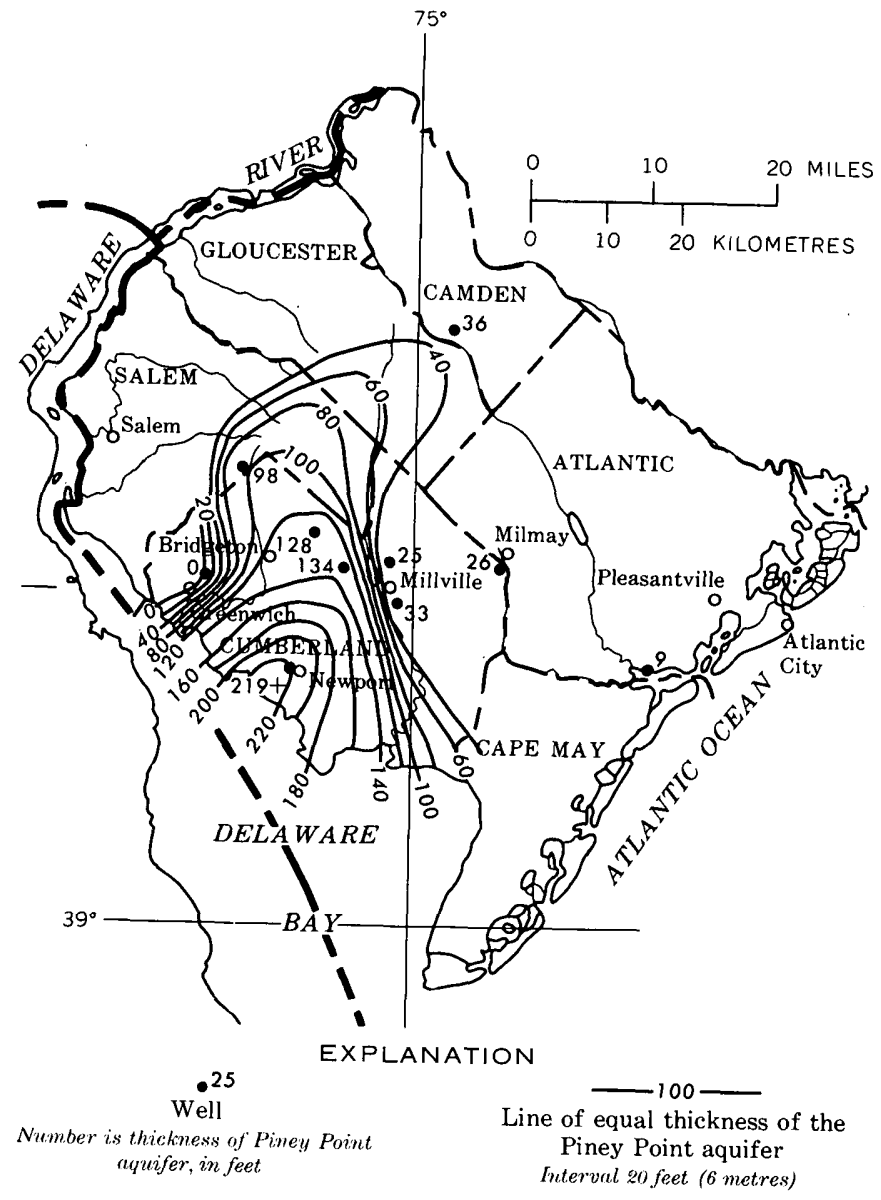

Figure 2.-Thickness of the Piney Point aquifer.

The Piney Point aquifer lies entirely within the subsurface in New Jersey and Delaware. In Delaware the Piney Point aquifer is an elongate lens of sand striking northeast and generally dipping toward the southeast. Well clata in Delaware suggest that the Piney Point is located in a northeast-trending trough, the centerline of which is near Dover and Frederica, Del. (Sundstrom and Pickett, 1968, p. 17). This centerline and the thickest section of sandy sediments extend into Cumberland County, N.J., according to interpretations of geophysical and lithologic logs. Sundstrom and Pickett (1968) indicate that this thick sand accumulation in Delaware may be the result of deposition in a structural trough or on a beach. Data collected in New Jersey indicate a marginal marine beach environment. The aquifer material grades gradually into sandy silt to the northeast. Northwestward, toward the Delaware River, the aquifer terminates fairly abruptly, probably due to erosion. Sections in figures 4 and 5 show the stratigraphic correlation and position of the Piney Point aquifer in Cumberland, Salem, and Gloucester Counties, N.J. Geophysical logs indicate that the aqui- 


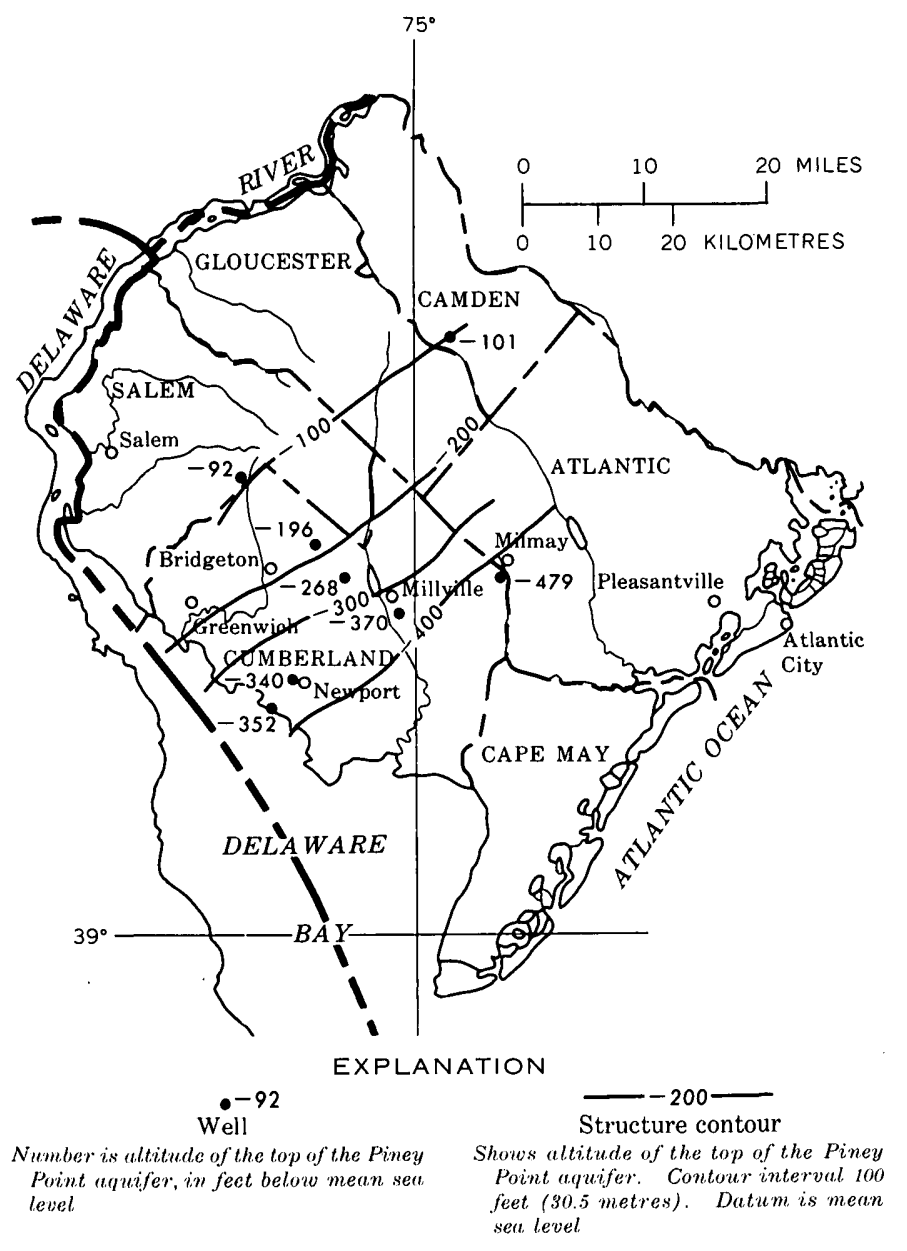

Figure 3.-Structure contours on top of the Piney Point aquifer: fer material grades into silt and clay northeastward in Camden County (Farlekas, Nemickas, and Gill, 1973). 'The authors' interpretation is that the aquifer was deposited in a beach environment and that the thickest part of the sand unit may represent an offshore bar.

\section{ALLOWAY CLAY MEMBER OF THE KIRKWOOD FORMATION}

The Alloway Clay Member of Kümmel and Knapp (1904, p. 142), as redefined by Isphording (1970), is herein adopted and is defined as the basal marine clay member of the Kirkwood Formation in Salem, Cumberland, Gloucester, and Atlantic Counties in southern New Jersey. The contact between the Alloway Clay Member and Piney Point aquifer is marked by the abrupt and widespread occurrence of large amounts of reworked greensand from the Piney Point aquifer in the Alloway Clay Member. The Alloway Clay Member consists of dark-brown or grayish-brown to light-tan silty clay and contains abundant shell fragments. Mineralogic work by Isphording and Lodding (1969) on the Alloway Clay Member indicates that the clay is remarkably homogeneous both laterally and vertically. The high percentage of montmorillonite and the fine texture of the sediments reflect marine depositional conditions (Isphording and Lodding, 1969, p. 8). In the present paper, the Alloway Clay Member is extended from Cumberland County into Gloucester, Atlantic, and Camden Counties on the basis of geophysical logs and lithologic samples.

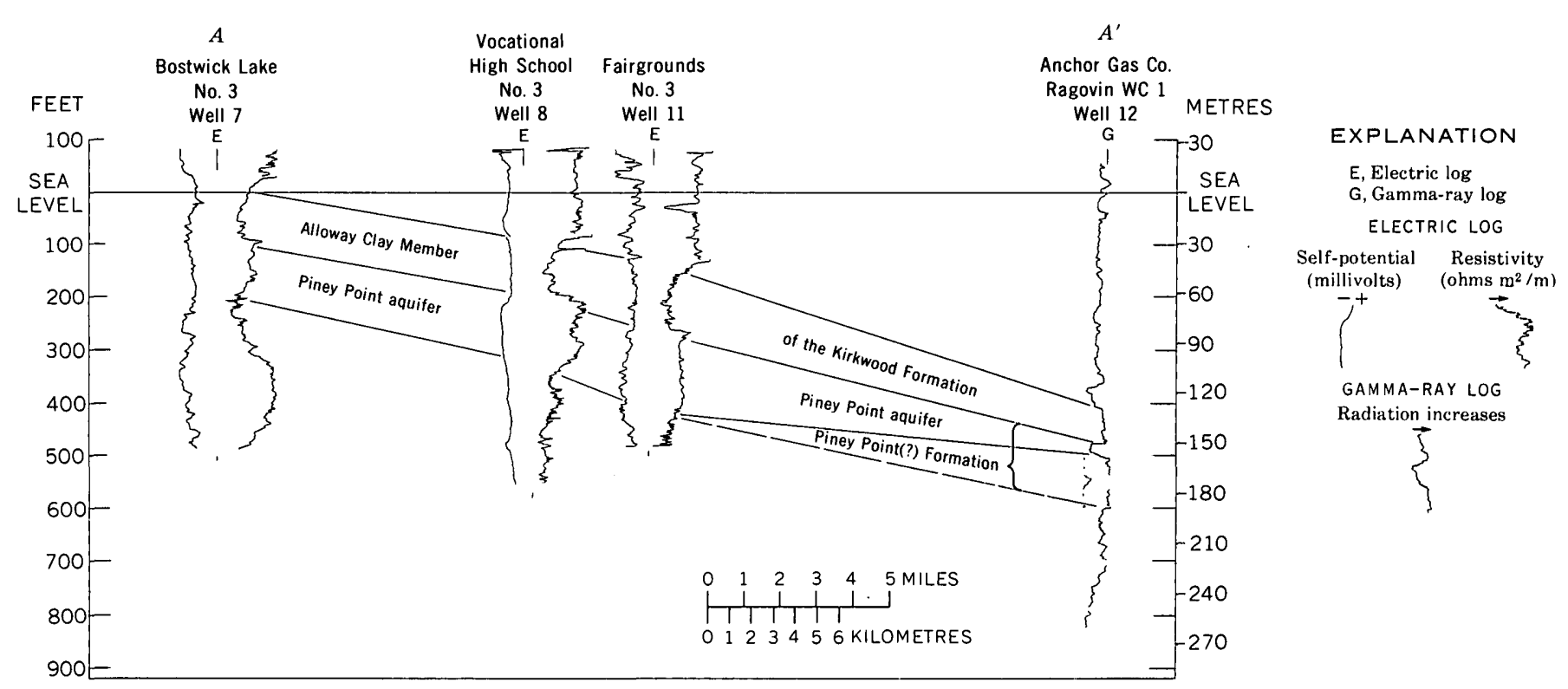

Figure 4.- Section $A-A^{\prime}$ showing correlation of the Alloway Clay Member of the Kirkwood Formation and the Piney Point aquifer in the study area. See figure 1 for locations of wells. 


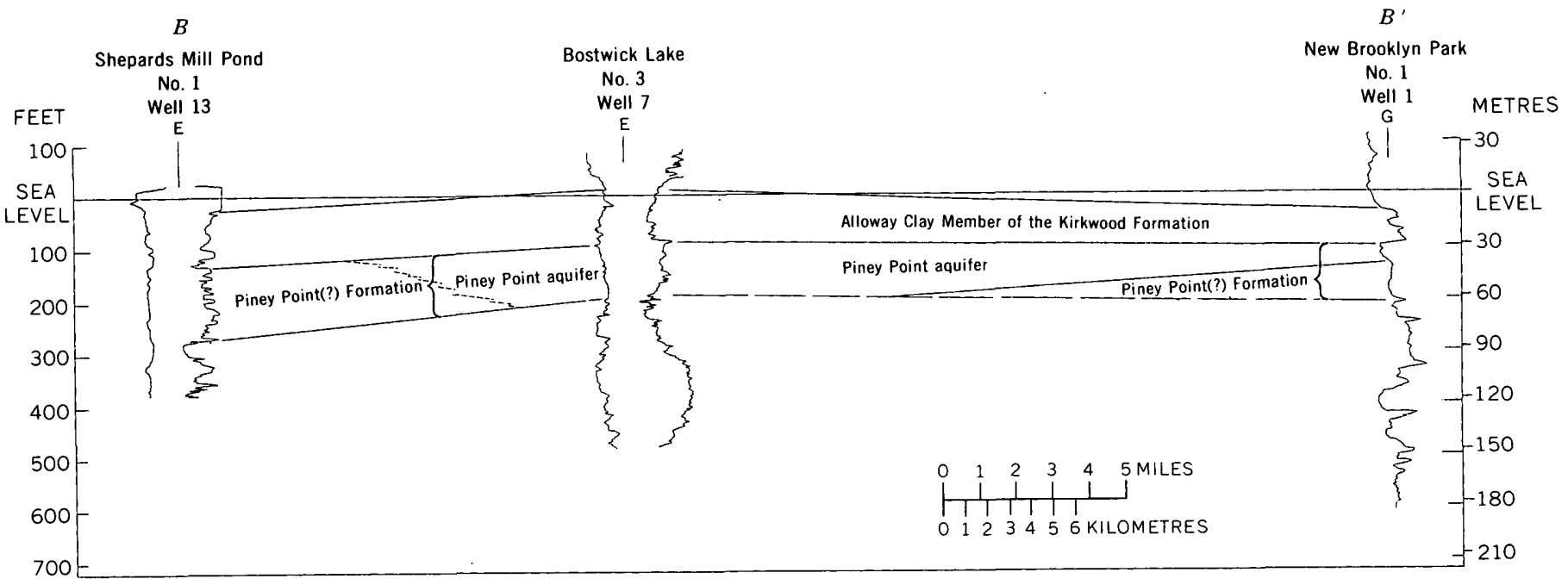

Figure 5.-Section $B-B^{\prime}$ showing correlation of the Alloway Clay Member of the Kirkwood Formation and the Piney Point aquifer in the study area. See figure 1 for locations of wells. Explanation same as for figure 4 .

The Alloway Clay Member is hydrologically significant in the report area because it acts as a highly confining unit overlying the Piney Point aquifer (figs. 4 and 5). Lithologic and hydraulic properties determined from core samples are given in table 1 . Its vertical hydraulic conductivity, determined from four core samples in Cumberland County, ranges from $2.0 \times 10^{-5}$ to $5.2 \times 10^{-5} \mathrm{ft} / \mathrm{d}\left(6.0 \times 10^{-6}\right.$ to $\left.1.6 \times 10^{-5} \mathrm{~m} / \mathrm{d}\right)$. Its thickness ranges from $152 \mathrm{ft}(46.3 \mathrm{~m})$ near Greenwich to $64 \mathrm{ft}(19.5 \mathrm{~m})$ near Milmay, both in Cumberland County (fig. 6). The top of the Alloway Clay Member (fig. 7) has a regional dip of 20 to $25 \mathrm{ft} / \mathrm{mi}(9.8-12.2$ $\mathrm{m} / \mathrm{km})$. In the New Jersey Coastal Plain the Alloway Clay Member grades laterally into the Grenlock Sand Member of Isphording (1970), which is a fine silty sand that makes up the bulk of the Kirkwood Formation.

\section{HYDROLOGY}

The Piney Point aquifer is tapped in Cumberland County by only a few wells. Yields of these wells are generally $100 \mathrm{gal} / \mathrm{min}(6.3 \mathrm{l} / \mathrm{s})$ or less. Additional wells of moderate yield ( $50-150 \mathrm{gal} / \mathrm{min}$ or $3.2-9.5 \mathrm{l} / \mathrm{s}$ ) can be developed, especially in southwestern Cumberland County.

Results of aquifer tests of the Piney Point aquifer on the Delmarva Peninsula indicate that transmissivity ranges from 1,200 to $6,000 \mathrm{ft}^{2} / \mathrm{d}\left(112-557 \mathrm{~m}^{2} / \mathrm{d}\right)$ and that coefficient of storage ranges from 0.002 to 0.004 (Cushing, Kantrowitz, and Taylor, 1973). Similar data are lacking in New Jersey, but the authors believe that comparable values can be expected in the southwestern part of New Jersey, where the Piney

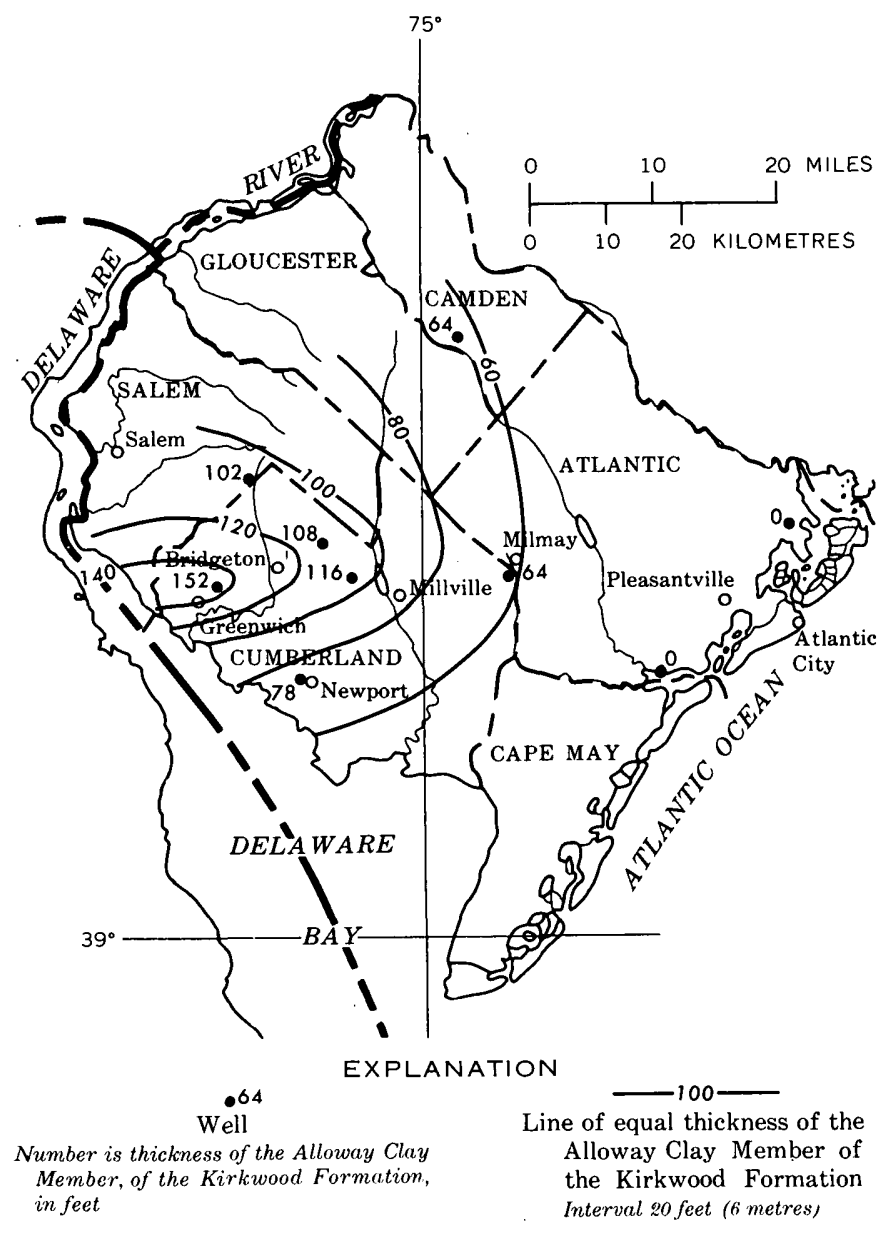

Figure 6.-Thickness of the Alloway Clay Member of the Kirkwood Formation.

Point aquifer consists of a thick sequence of fine to coarse sand. 


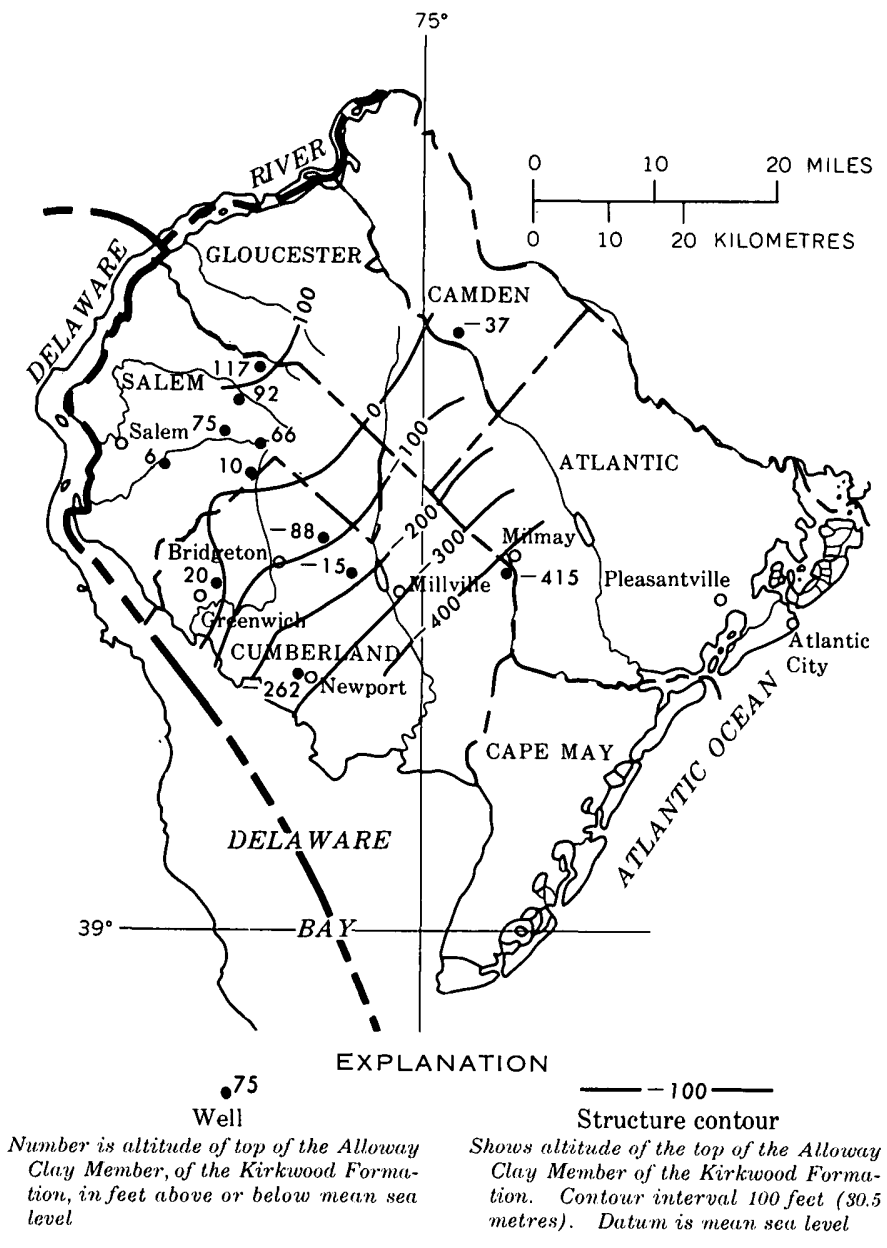

Fraure 7.-Structure contours on top of the Alloway Clay Member of the Kirkwood Formation.

About $9 \mathrm{Mgal} / \mathrm{d}\left(0.4 \mathrm{~m}^{3} / \mathrm{s}\right)$ of water is pumped from the Piney Point aquifer in Delaware, about 75 percent of which is used for municipal and industrial supplies in and near Dover, Del., and Cambridge, Md., (Cushing, Kantrowitz, and Taylor, 1973). A comparison of the water-level altitudes in two wells in Cum- berland County, $+23 \mathrm{ft}(+7 \mathrm{~m})$ in well 11 (fig. 1) and $-3 \mathrm{ft}(-1 \mathrm{~m})$ in well 16 (fig. 1), indicates a possible decline of water levels in the Piney Point aquifer in New Jersey caused by pumping in Delaware.

\section{WATER QUALITY}

Three water samples for chemical analysis were obtained from the Piney Point aquifer when the Cumberland County observation-well network was established in 1972. The chemical analyses in table 2 (well locations are shown in fig. 1) show that the aquifer contains freshwater in this area. Chloride concentration is low, ranging from 1 to $32 \mathrm{mg} / \mathrm{l}$. However, other waterquality data collected from the Piney Point aquifer near Delaware Bay indicate a higher chloride concentration. A water sample taken in 1973 at the Gandys Beach well (No. 18 in fig. 1) contained $516 \mathrm{mg} / 1$ of chloride, and a sample taken in 1973 at the Money Island Marina well (No. 17 in fig. 1) contained 73 $\mathrm{mg} / \mathrm{l}$ of chloride. A water sample taken in November 1972 at the Jones Island well (No. 16 in fig. 1), which is farther from the bay, contained only $4 \mathrm{mg} / \mathrm{l}$ of chloride. This sample was taken from the screened interval in the upper part of the aquifer. An electric $\log$ of the Jones Island well before the well was completed shows an increase in electrical conductivity toward the lower part of the aquifer, which may be caused by a higher concentration of chloride near the base of the aquifer (Nemickas, 1974). A generalized section (fig. 8) shows an interpretation of the freshwater-saltwater interface in the Piney Point aquifer that explains the chloride concentrations in wells 16 , 17 , and 18 in figure 1 . In Delaware the chloride concentration in the aquifer increases downdip, and this relationship may exist in New Jersey, but no data are available for substantiation. Another posibility is that the thalweg of Delaware Bay has partly or completely

TABLE 1.-Lithologic and hydrologic properties of the Alloway Clay Member of the Kirkwood Formation [Analysis by U.S. Geological Survey, Denver, Colo. Well locations shown in fig. 1]

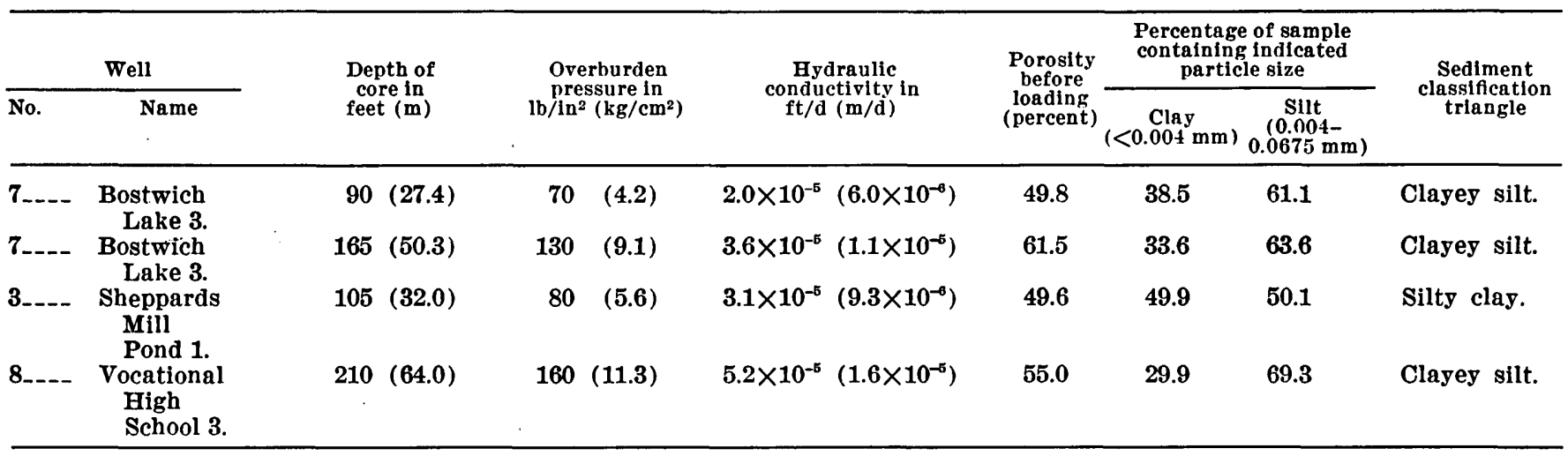



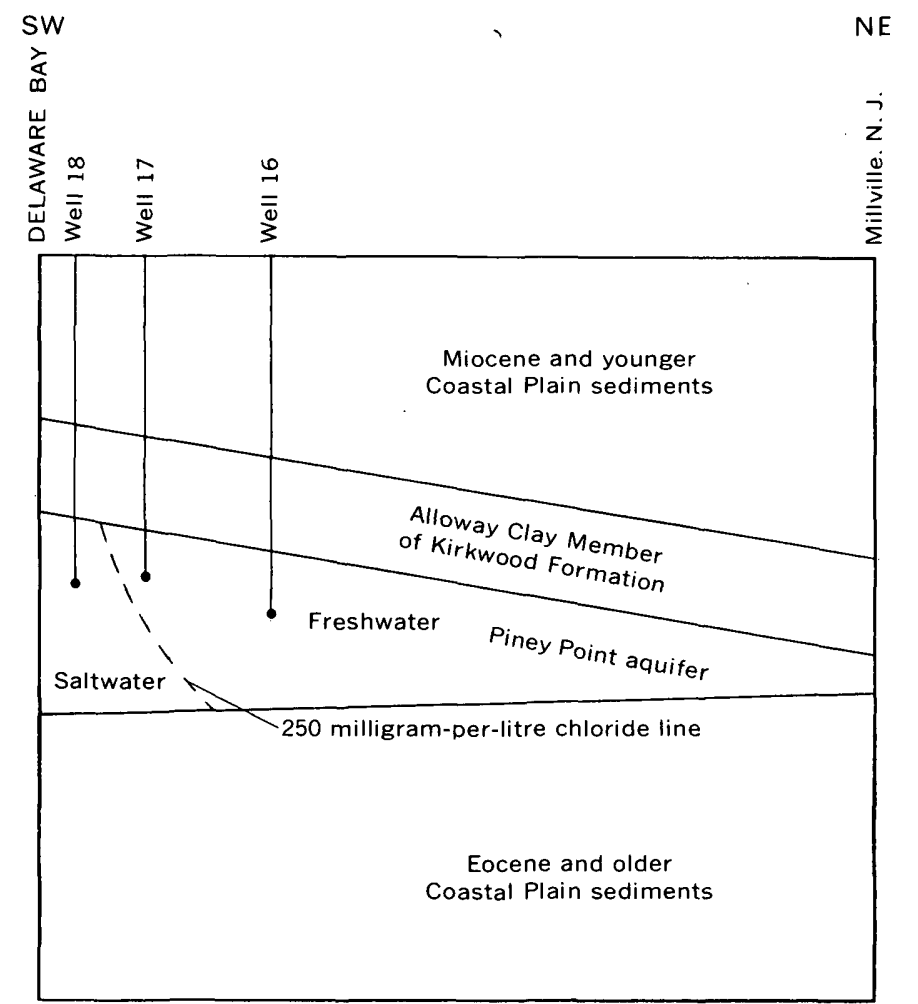

Figure 8.-Generalized section from Delaware Bay to Millville, N.J., showing the inferred saltwater interface in the Piney Point aquifer in Cumberland County. Not to scale.

TABLE 2.-Chemical analyses of water from the Piney Point aquifer

[Analyses by U.S. Geological Survey; results in milligrams per litre except for temperature, specific conductance, $\mathrm{pH}$, and color. Well locations are shown in fig. 1]

\begin{tabular}{|c|c|c|c|}
\hline & Well 7 & Well 8 & Well 16 \\
\hline Date of collection & $10-3-72$ & $10-4-72$ & $10-5-72$ \\
\hline Temperature & 13.2 & 15 & 14.5 \\
\hline Silica $\left(\mathrm{SiO}_{2}\right)$ & 38 & 10 & 53 \\
\hline Total iron (Fe) & .67 & .2 & .52 \\
\hline Total manganese $(\mathrm{Mn})$ & .01 & .0 & .0 \\
\hline Calcium ( $\mathbf{C a})$ & 25 & 10 & 29 \\
\hline Magnesium ( $\mathbf{M g}$ ) & 10 & 3.5 & 3.2 \\
\hline Sodium (Na) & 66 & 94 & 10 \\
\hline Potassium (K) & 11 & 8.8 & 3.5 \\
\hline Sulfate $\left(\mathrm{SO}_{4}\right)$ & .5 & 7.0 & 11 \\
\hline Chloride (Cl) & 1.0 & 32 & 4.0 \\
\hline Fluoride (F) & .5 & .9 & .1 \\
\hline Nitrate $\left(\mathrm{NO}_{3}\right)$ & 1.8 & .9 & .4 \\
\hline Orthophosphorus (P) & .03 & .038 & .18 \\
\hline Orthophosphate $\left(\mathrm{PO}_{4}\right)$ & --- & --- & .55 \\
\hline Bicarbonate $\left(\mathrm{HCO}_{3}\right)$ & 293 & 237 & 116 \\
\hline Carbonate $\left(\mathrm{CO}_{3}\right)$ & 0 & 7.0 & 0 \\
\hline Carbon Dioxide $\left(\mathrm{CO}_{2}\right)$ & 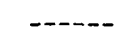 & & 1.5 \\
\hline Alkalinity as $\mathrm{CaCO}_{3}$ & --- & & 95 \\
\hline Noncarbonate hardness & $\mathbf{0}$ & $\mathbf{0}$ & 0 \\
\hline Hardness-Ca, Mg & 104 & 39 & 86 \\
\hline Dissolved solids (residue & & & \\
\hline at $\left.180^{\circ} \mathrm{C}\right)$ & 291 & 288 & 174 \\
\hline Dissolved solids _- & 302 & 286 & 171 \\
\hline Specific conductance $--\mathrm{mho}_{--}$ & 447 & 484 & 210 \\
\hline pH (units) & 8.1 & 8.5 & 8.1 \\
\hline Color (plutonium-cobalt scale) - & 4.0 & 5.0 & 2.0 \\
\hline
\end{tabular}

incised the Alloway Clay Member of the Kirkwood Formation. This would cause vertical leakage of water with high chloride concentration into the aquifer from Delaware Bay. Also, a lithologic change of the Alloway Clay Member to a more permeable unit can explain the high chloride concentration of the water in the aquifer at the Gandys Beach site. The more permeable lithology may also induce vertical leakage into the aquifer from Delaware Bay.

Iron concentration in the three samples in table 2 ranges from 0.2 to $0.67 \mathrm{mg} / \mathrm{l}$, and the "Potable Water Standards" (New Jersey State Department of Environmental Protection, 1970) allows a maximum of $0.5 \mathrm{mg} / \mathrm{l}$ of iron in potable water. A potential iron problem exists if the water from the Piney Point aquifer is used for public supply.

\section{CONCLUSIONS}

The Piney Point aquifer in New Jersey is as thick as $220 \mathrm{ft}(67 \mathrm{~ms})$ and for the most part is a freshwater aquifer that is laterally continuous with the Piney Point aquifer of the Delmarva Peninsula. The aquifer, of Eocene age, consists of fine to coarse glauconitic sand in the area of Newport in Cumberland County, N.J. The aquifer grades into greenish clay and silt to the cast, and near Atlantic City the dominant lithology is marine silt and clay. 'To the northeast, toward Burlington and Ocean Counties, the glauconitic sand grades laterally into a marine silty clay. To the northwest, toward the Delaware River, the coarse sand terminates abruptly, possibly truncated by erosion; and is not found in outcrop. The lithologic character indicates deposition in a marginal marine beach environment with the coarse sands possibly representing the axis of a former offshore bar.

Water-quality analyses indicate a possible freshwater-saltwater interface in the Piney Point aquifer near Delaware Bay. Furthermore, the negative altitude of water level in the Piney Point aquifer in Cumberland County near Delaware Bay suggests that pumping in Delaware is lowering the water level in New Jersey. Continued collection of water-level and waterquality data would serve to indicate changes in the Piney Point aquifer.

The Alloway Clay Member of the Kirkwood Formation overlies the Piney Point aquifer and ranges in thickness from $152 \mathrm{ft}(46.3 \mathrm{~m})$ near Greenwich to 64 ft $(19.5 \mathrm{~m})$ near Milmay. Its vertical hydraulic conductivity determined from four core samples in Cumberland County ranges from $2.0 \times 10^{-5}$ to $5.2 \times 10^{-5}$ $\mathrm{ft} / \mathrm{d}\left(6.0 \times 10^{-6}\right.$ to $\left.1.6 \times 10^{-5} \mathrm{~m} / \mathrm{d}\right)$. The Alloway Clay Member acts as a confining unit, separating the Piney 
Point aquifer from the Kirkwood aquifer in Cumberland County.

\section{REFERENCES CITED}

Brown, P. M., Miller, J. A., and Swain, F. M., 1972, Structural and stratigraphic framework and special distribution of permeability of the Atlantic Coastal Plain, North Carolina to New York: U.S. Geol. Survey Prof. Paper 796, 79 p.

Cushing, E. M., Kantrowitz, I. H., and Taylor, K. R., 1973 Water resources of the Delmarva Peninsula: U.S. Geol. Survey Prof. Paper 822, $58 \mathrm{p}$.

Farlekas, G. M., Nemickas, Bronius, and Gill, H. E., 1973 Geology and ground-water resources of Camden County, New .Jersey : U.S. Geol. Survey open-file rept, $162 \mathrm{p}$.

Isphording, W. C., 1970, Petrology, stratigraphy and re-definition of the Kirkwood Formation (Miocene) of New Jersey : Jour. Sed. Petrology, v. 40, no. 4, p. 986-997.

Isphording, W. C., and Lodding, William, 1969, Facies changes in sediments of Miocene age in New Jersey, in Subitzky, Seymour, ed., Geology of selected areas in New Jersey and eastern Pennsylvania : New Brunswick, N.J., Rutgers Univ. Press, p. 7-13.
Kuimmel, H. B., and Knapp, G. N., 1904, The stratigraphy of the New .Jersey clays, Pt. 2 of Ries, Heinrich, and Kümmel, H. B., The clays and clay industry of New Jersey : New Jersey Geol. Survey, Final Rept., v. 6, p. 117-209.

Nemickas, Bronius, 1974, Test drilling program to establish observation wells in Cumberland County, New Jersey: U.S. Geol. Survey open-file rept.

New Jersey State Department of Environmental Protection, 1970, Potable water standards : New Jersey Dept. Environmental Protection, 6 p.

Otton, E. G., 1955, Ground-water resources of the southern Maryland Coastal Plain: Maryland Dept. Geology, Mines and Water Resources Bull. 15, 347 p.

Rasmussen, W. C., Groot, J. J., and Depman, A. G., 1958, High. capacity test well developed at the Air Force Base, Dover, Deleware: Delaware Geol. Survey Rept. Inv., no. 2, 36 p.

Rasmussen, W. C., Slaughter, J. H., Hulme, A. E., and Murphy, J. J., 1957, The water resources of Carolina, Dorchester, and Talbot Counties: Maryland Dept. Geology, Mines and Water Resources Bull. 18, $465 \mathrm{p}$.

Richards, H. G., 1956, Geology of the Delaware Valley: Philadelphia, Mineralogic Soc. Pennsylvania, $106 \mathrm{p}$.

Sundstrom, R. W., and Pickett, T. E., 1968, The availability of ground water in Kent County, Delaware: Newark, Delaware Univ. Water Resources Center, 123 p. 


\title{
LAND SUBSIDENCE AND AQUIFER-SYSTEM COMPACTION IN THE SAN JACINTO VALLEY, RIVERSIDE COUNTY, CALIFORNIA-A PROGRESS REPORT
}

\author{
By BEN E. LOFGREN, Sacramento, Calif.
}

\begin{abstract}
Widespread subsidence continues in the San Jacinto structural trough as water levels continue to decline. Subsidence is due principally to the compaction of water-bearing deposits as effective stresses are increased by artesianhead decline. Other possible contributory causes of subsidence are (1) local or regional tectonic adjustments and graben downfaulting, (2) natural compaction of deep water-bearing deposits below the bottom of well casings, and (3) continuing compaction of surficial deposits due to causes other than artesian-head decline.

A careful analysis of $4 \mathrm{yr}$ of correlative records of waterlevel, extensometer, and land-surface changes suggests three types of vertical ground movement occurring at the $4 \mathrm{~S} / 1 \mathrm{~W}-$ 21N2 recorder site near the San Jacinto reservoir site. The reservoir was drained in October 1973. Listed in descending order of magnitude these are (1) an elastic undulation of the land surface of about $0.06 \mathrm{ft}(0.02 \mathrm{~m})$ per year in close response to the roughly $50 \mathrm{ft}(15 \mathrm{~m})$ of seasonal water-level fluctuations, (2) a long-term permanent compaction of the deposits in the 0-1,237-ft $(0-377-\mathrm{m})$ zone of about $0.04 \mathrm{ft}$ $(0.01 \mathrm{~m})$ per year, and (3) a deep settlement, of deposits below the 1,237-ft $(377-\mathrm{m})$ extensometer anchor of $0.01-0.02 \mathrm{ft}$ $(0.003-0.006 \mathrm{~m})$ per year, probably caused by continuing downfaulting in the graben trough. The specific compaction of the aquifer system at this site from 1970 to 1974 was about $1.3 \times 10^{-2}$ (units of compaction per unit of increase in applied stress). The specific. expansion during this period decreased progressively from $1.29 \times 10^{-3}$ (units of expansion per unit of stress decrease) in 1970-71 to $0.95 \times 10^{-3}$ in $1973-74$, suggesting that excess pore pressures in the slow-draining aquitards were not completely dissipated each year.
\end{abstract}

In this report values are given in both U.S. customary and metric (International System) units of measurement. Following is a list of the factors used for conversion of the U.S. units to the metric units:

$\begin{array}{lll}\text { Inch } & \times & 2.540 \text { =centimetres } \\ \text { Foot } & \times & 0.3048 \text { =metre } \\ & \times & 30.48 \text { =centimetres } \\ & \times & 304.8 \text { =millimetres } \\ \text { Foot of water }\left(39.2^{\circ} \mathrm{F}\right) & \times & 0.433 \text { =pounds per square inch } \\ & \times 2,990 \quad \text { =pascals } \\ \text { Mile } & \times & 1.609 \text { =kilometres } \\ \text { Square mile } & \times & 2.590=\text { square kilometres }\end{array}$

San Jacinto Valley is an alluviated structural valley situated within the San Jacinto fault zone, $80 \mathrm{mi}$ (130 $\mathrm{km}$ ) east of Los Angeles. It comprises about $300 \mathrm{mi}^{2}$ $\left(780 \mathrm{~km}^{2}\right)$ of relatively flat-lying flood plain, surrounded by hills and mountains. In the vicinity of the city of San Jacinto (fig. 1), the valley consists of a northwest-trending sediment-filled graben of large displacement, bounded by the Claremont fault and the San Jacinto Mountains on the east and by the Casa Loma fault and a broad alluvial "mesa" on the west. The San Jacinto River, which flows northwesterly through the valley, is the source not only of most of the detritus that has filled the sinking graben trough, but also of most of the recharge to the extensive ground-water reservoir of the valley.

Extensive ground-water development has produced significant hydrologic changes in San Jacinto Valley, especially since the middle 1940's. Ground-water levels have declined throughout much of the valley, largely as a result of pumping overdraft. Artesian heads which generally were as much as $25 \mathrm{ft}(7 \mathrm{~m})$ above the land surface during the 1920's and early 1930's were more than $200 \mathrm{ft}(60 \mathrm{~m})$ below the land surface during the early 1970's. Concurrently, widespread land subsidence has been observed in many areas where leveling control is available. Also, areas of differential settlement and earth fissures have developed in numerous localities in the valley.

Many of these surface phenomena undoubtedly are directly related to declining water levels in the artesian basin. Some, however, may be due to bedrock adjustments in the tectonically active structural trough or possibly to continuing compaction of surficial deposits.

To differentiate tectonic adjustments from the compaction of water-bearing deposits and also to approximate the stress-strain characteristics of the aquifer system at one location, a recording extensometer was installed in a specially drilled observation well in 


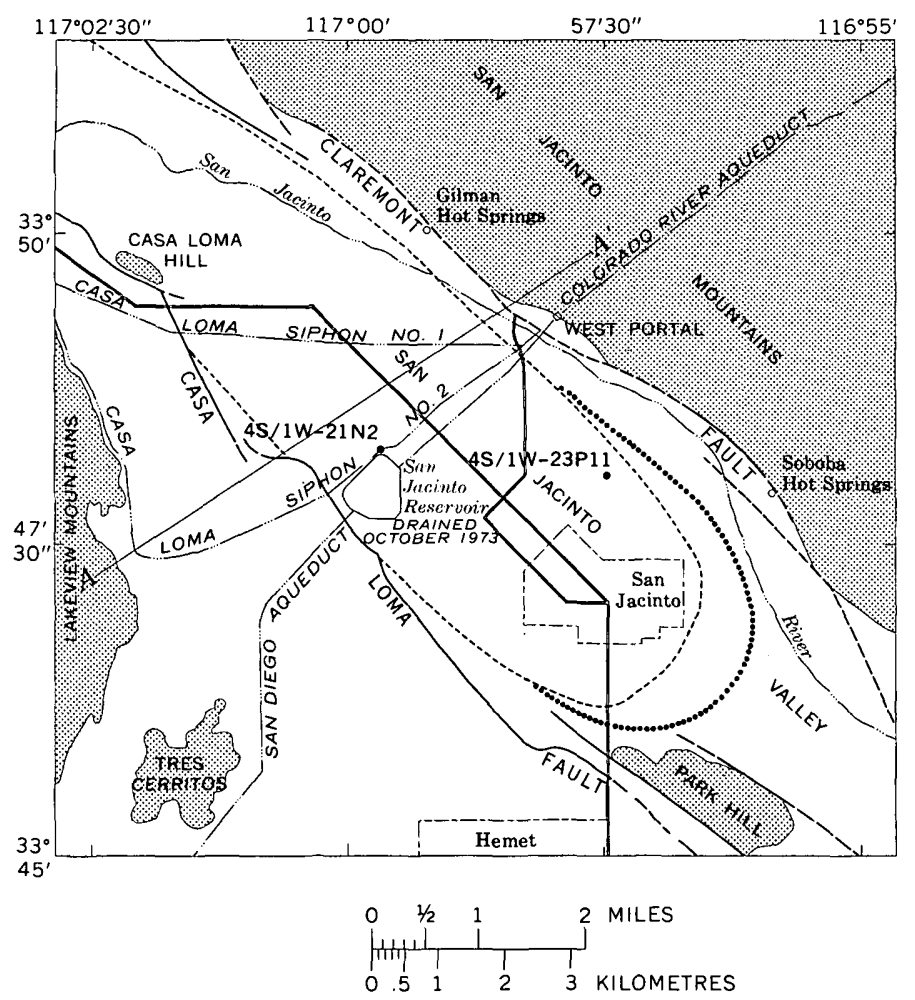

1 Consolidated and semiconsolidated rocks (From Calif. Dept. Water Resources, 1959, pl. B-1B)

Major fault-Dashed where inferred; queried where doubtful
(From Calif. Dept. Water Resources, 1959, pl. B-1B)
Boundary of area of flowing wells in 1915 (From Waring,
1919, pl. 3)

Figure 1.-Map showing pertinent hydrogeologic features in the vicinity of the San Jacinto reservoir site, Riverside County, Calif.

August 1970. This extensometer installation is at well $4 \mathrm{~S} / 1 \mathrm{~W}-21 \mathrm{~N} 2$ near the north edge of the San Jacinto reservoir site (drained in Ootober 1973) (fig. 1), in an area where long-term water-level decline and subsidence are known to have occurred and where local and regional leveling control are most extensive.

The purposes of this report are to describe briefly the extensometer installation and the records obtained, to interpret the first $4 \mathrm{yr}$ of these extensometer records and correlate the recorded changes of aquifer-system thickness with measured water-level fluctuations, to approximate the elastic and inelastic stress-strain parameters of the aquifer system, and to attempt to differentiate surficial ground-water effects from deep tectonic movement. To the extent the various components and causes of the land-surface change can be deter- mined and the stress-strain parameters of the aquifer system established at this recorder site, these relationships can probably be extrapolated to other parts of the graben valley.

Acknowledgments.-This subsidence investigation by the U.S. Geological Survey is in cooperation with the Southern District of the California Department of Water Resources. Most of the basic data in this interpretive report are from other agencies or published reports. The single large expenditure in this project, the drilling of the test well, was a joint undertaking by the California Department of Water Resources, the Metropolitan Water District of Southern California, Eastern Municipal Water District, and the Geological Survey. All the leveling control and several of the graphs of this report, as well as the site and access for the observation well, have been provided by the Metropolitan Water District of Southern California. Eastern Municipal Water District services the field recorders monthly. Radiocarbon dates reported herein were made by the Geological Survey on wood samples collected in June 1971 by personnel of the Eastern Municipal Water District and Metropolitan Water District.

\section{HYDROGEOLOGIC SETTING}

For purposes of this preliminary report, the schematic section of figure 2 serves as a simplified model of the San Jacinto graben valley (fig. 1) and aids in describing the nature and extent of this investigation.

The graben trough is bounded on the southwest by the Casa Loma fault (Proctor, 1962) and on the northeast by the Claremont fault (Henderson, 1939). Unconsolidated alluvial deposits, which comprise the productive ground-water reservoir in San Jacinto Valley, are nonexistent northeast of the Claremont fault. 'These deposits range in depth from zero to about $2,000 \mathrm{ft}(610 \mathrm{~m})$ (fig. 2) in the graben and thin from $600 \mathrm{ft}(183 \mathrm{~m})$ to zero west of the Casa Loma fault. Within the graben, the heavily pumped water-bearing alluvial deposits are underlain by a thick sequence of unconsolidated continental deposits of low permeability, accumulated during a long history of graben downfaulting.

Seismic studies (Fett and others, 1967) suggest that the bedrock surface, which rises abruptly several thousand feet above the valley east of the graben, lies $7,000-8,000 \mathrm{ft}(2,100-2,400 \mathrm{~m})$ beneath the alluvial surface in the graben and is less than $600 \mathrm{ft}(183 \mathrm{~m})$ deep west of the graben. The bedrock geology of the area is varied and complex, and tectonism has played a dominant role in shaping the present landscape (Sharp, 1972). In addition to large vertical offsets, 

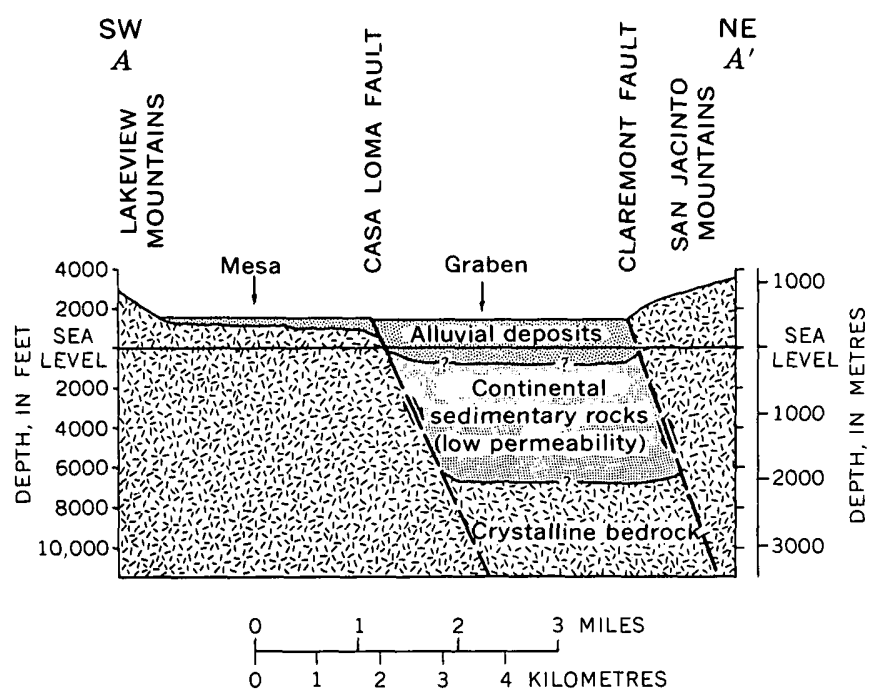

Frgure 2.-Schematic geologic section across San Jacinto Valley, one-half mile northwest of the San Jacinto reservoir site. (Modified from J. D. Fett and Associates written conmun., 1967; also modified from Jofgren and Rubin, 1975, fig. 2.)

apparently many miles of right-lateral horizontal movement have occurred within the San Jacinto fault zone. For a regional background of the geology of the area, see Woodford and others (1971).

The Casa Loma fault (fig. 1) has left a distinct scarp along the valley, and recent mapping (Sharp, 1967, p. 711; Sharp, 1972) suggests that, although right-lateral offsets have dominated within the San Jacinto fault zone in Holocene time, recent movement along the Casa Loma fault has been largely dip slip. Surveys by the Metropolitan Water District of Southern California (Proctor, 1974) indicate $0.12 \mathrm{ft}(0.037$ $\mathrm{m}$ ) of right-lateral movement (creep) at one location on the Casa Loma fault since 1958; however, neither the rate nor extent of displacement in historic time is well known. In the vicinity of San Jacinto reservoir site, the Casa Loma fault is an effective ground-water barrier (Proctor; 1962, p. 1295), separating a relatively unconfined ground-water reservoir under the mesa to the west (fig. 2) from a complex confined reservoir system in the graben (California Department Water Resources, 1959, app. B and F). Marked differences across the fault are noted not only in the head in observation wells, but also in the pattern of seasonal waterlevel fluctuations and subsidence rates. These differences are due largely to the marked contrast in both the nature of the water-bearing deposits and also the pumping draft within the graben as compared to the mesa west of the Casa Loma fault.

\section{EXTENSOMETER INSTALLATION}

In areas of intensive ground-water overdraft, stress changes in the formation frequently cause measurable changes in thickness of the water-bearing deposits (Lofgren, 1968). To differentiate these relatively shallow effects, usually extending to depths of the deepest pumping wells, from possible deep tectonic downfaulting, a highly sensitive extensometer was installed in specially drilled observation well $4 \mathrm{~S} / 1 \mathrm{~W}-21 \mathrm{~N} 2$. With this equipment, the cyclical elastic changes in thickness and the long-term permanent compaction of the water-bearing deposits in the interval from the land surface to the depth of the extensometer anchor are measured. When correlated with concurrent waterlevel fluctuations, these extensometer data enable the calculation of the stress-strain parameters of the aquifer system at that location. Also, when compared with surface subsidence, as determined by periodic surveys from a distant stable reference, the amount of settlement occurring below the extensometer depth anchor can be calculated.

Observation well $4 \mathrm{~S} / 1 \mathrm{~W}-21 \mathrm{~N} 2$ is situated about $200 \mathrm{ft}(60 \mathrm{~m})$ north of San .Jacinto reservoir site and half that distance north of Casa Loma siphon No. 2 which has been periodically resurveyed since 1959 (figs. 1 and 6). The well was completed in August 1970 to a final depth of $1,237 \mathrm{ft}(377 \mathrm{~m})$. Figure 3 shows the casing log of the completed well and also the electric logs of the drill hole by Go International, Inc., before the casing was installed. Two types of recording equipment have been maintained in this well since August 1970-a highly sensitive down-hole extensometer that measures the change in thickness of the water-bearing deposits to a depth of $1,237 \mathrm{ft}(377 \mathrm{~m})$, and a conventional air-line water-level recorder. The down-hole extensometer assembly consists of a string of $11 / 2$-in $(3.8-\mathrm{cm})$ galvanized pipe of nominal $21-\mathrm{ft}$ (6.t-m) lengths coupled with extra heavy couplings, lowered inside the $51 / 2$-in $(14-\mathrm{cm})$ pipe to well bottom and cemented to the formation with a $10-\mathrm{ft}(3-\mathrm{m})$ plug of concrete bottomed at $1,237 \mathrm{ft}(377 \mathrm{~m})$. A modified Stevens type F, 32-day recorder, mounted on a steel frame over the well, measures the varying height of the land surface with respect to the top of the $11 / 2$-in $(3.8-\mathrm{cm})$ pipe. This recording extensometer has proved relatively insensitive to surface temperature changes, principally because down-hole temperatures change only slightly below a depth of a few feet, and also, the thermal characteristics of the pipe above the land surface are about the same as the legs of the steel frame holding the recorders. The water-level recorder, a 30-day Bristol pressure type, is connected 


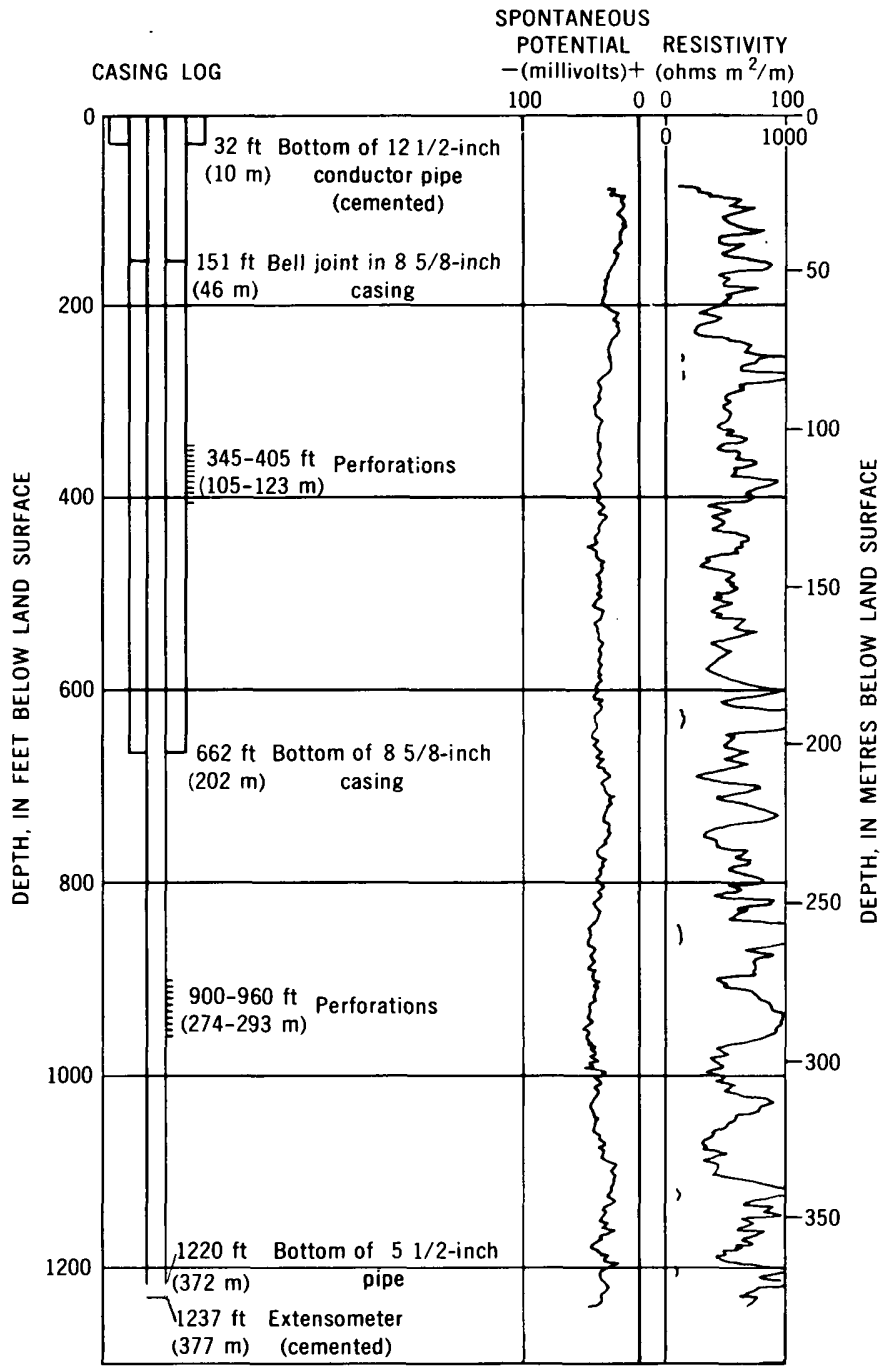

Figure 3.-Casing and electric $\operatorname{logs}$ of well $4 \mathrm{~S} / 1 \mathrm{~W}-21 \mathrm{~N} 2$.

to a $1 / 4$-in $(0.64-\mathrm{cm})$ air line extending below the water surface in the $51 / 2$-in $(14-\mathrm{cm})$ pipe and monitors the composite head of sands in the 900 to $960-\mathrm{ft}$ (275 to $290-\mathrm{m}$ ) and 1,220 to $1,227-\mathrm{ft}$ (372 to $374-\mathrm{m})$ depth zones (fig. 3).

\section{RADIOCARBON DATES INDICATE RATES OF DOWNFAULTING}

Natural compaction of the unconsolidated deposits in the San Jacinto graben has continued through Quaternary time as the graben floor has sunk and new overburden has been added at the surface. The rate of natural compaction has been extremely slow, however, as compared with the historic compaction caused by the excessive pumping of ground water.

Radiocarbon dates by the Geological Survey on wood samples (Tofgren and Rubin, 1975) from three depths in the fluvial fill of the valley give an average rate of deposition and an approximation of the implied average rate of graben downfaulting in the past 42,000 yr. The samples were collected in June 1971 from : rotary drilled water well $4 \mathrm{~S} / 1 \mathrm{~W}-23 \mathrm{P} 11,1 \mathrm{mi}(1.6 \mathrm{~km})$ due north of the city of San Jacinto. Specific details on the three samples are as follows:

\begin{tabular}{llll}
\hline \multicolumn{2}{c}{ Laboratory No. } & \multicolumn{1}{c}{$\begin{array}{c}\text { Depth of } \\
\text { sample in } \\
\text { feet (metres) }\end{array}$} & $\begin{array}{c}\text { Age } \\
\text { determination } \\
\text { (years B.P.) }\end{array}$ \\
\hline W-2729 & & $292(89)$ & $15,270 \pm 450$ \\
W-2827 & - & $322(98)$ & $21,260 \pm 650$ \\
W-2828 & - & $480(146)$ & $42,000 \pm 1500$ \\
\hline
\end{tabular}

The San Jacinto River, entering the valley from the southeast and leaving toward the west (fig. 1), apparently has maintained a uniform graded flood plain through much of Quatemary time. This flood plain serves as a reference datum for measuring rates of implied graben downfaulting. Apparent average rates of tectonic downfaulting were estimated at about 0.007 ft $(2.1 \mathrm{~mm})$ per year from $42,000 \mathrm{yr}$ to $15,270 \mathrm{yr}$ B.P. and about $0.019 \mathrm{ft}(5.8 \mathrm{~mm})$ per year since $15,270 \mathrm{yr}$ B.P. Since no data younger than $15,270 \mathrm{yr}$ B.P. are available, tectonic downfaulting during Holocene time may have proceeded at a uniform rate or may have had one or more episodes of abrupt subsidence.

\section{STRESS-STRAIN DATA AVAILABLE}

Under natural conditions, unconsolidated deposits are generally in equilibrium with their overburden load. An increase in grain-to-grain stress, however, due to either surficial loading or to hydraulic stresses produced by changes in ground-water levels, causes a corresponding strain or compaction of the deposits.

In the following analysis of the stress-strain characteristics of the water-bearing deposits in the San Jacinto Valley, three types of basic data are available for interpretation. These are (1) measured changes in land-surface elevation, as determined by periodic leveling to surface bench marks from stable reference ties outside the graben, (2) water-level fluctuations in selected observation wells, which are a rough measure of changes in effective stress in the aquifer system; and (3) at one location in the valley, extensometer records of changes in formation thickness in the zero to $1,237-\mathrm{ft}(377-\mathrm{m})$ depth zone.

\section{Subsidence data}

The only leveling control adequate for estimating long-term subsidence is repeated leveling tied to stable bench marks ontside of the subsiding area. Most of the leveling in the valley by city and comty agencies con- 
sists of short runs tied to "floating" bench marks, and thus is not usable for calculating subsidence trends.

Except for early leveling to a few bench marks of the National Geodetic Survey (formerly the Coast and Geodetic Survey) referred to by Proctor (1962) and Fett, Hamilton, and Fleming (1967), the leveling control available for calculating subsidence in the study area is restricted to bench marks along two cross-valley aqueducts (figs. 1 and 6 ) and more detailed control in the vicinity of the San Jacinto reservoir site. These bench marks have been releveled periodically since 1959 by the Metropolitan Water District.

In this interpretive study, no attempt is made to determine absolute elevation changes with respect to sea-level datum. Only relative movement of bench marks within and near the graben, with respect to a bedrock reference bench mark, are considered. Bench marks at West Portal in bedrock east of the graben (fig. 1) and also near San Jacinto reservoir site west. of the graben (fig. 6) have remained relatively consistent with respect to each other throughout the period of record and probably are as stable as any ties in this tectonically active region. Bench marks at West Portal serve as the reference datum for this study, even though recent evidence (written commun., 1974, Metropolitan Water District) indicates slight relative tectonic movement occurring in this area.

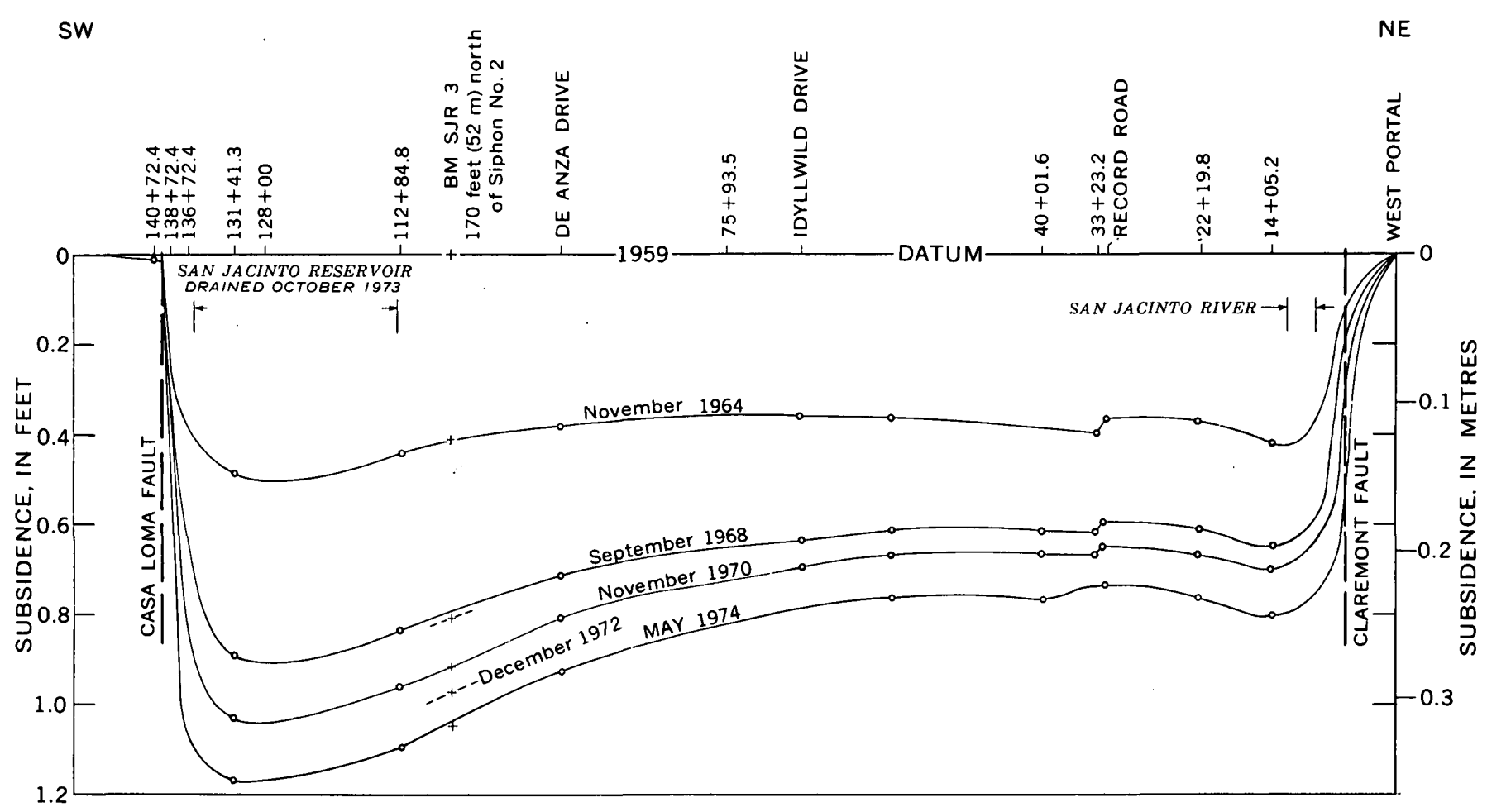

Figure 4.-Land-subsidence profles across the San Jacinto Valley along Casa Loma siphon No. 2, 1959-74. (Modified from pro-
files of the Metropolitan Water District of Southern California.)

Froure 4.-Land-subsidence profles across the San Jacinto Valley along Casa Loma siphon No.
files of the Metropolitan Water District of Southern California.)
Figure 4, modified from profiles prepared by the Metropolitan Water District, shows the measured subsidence along Casa Loma siphon No. 2 (fig. 1) and also reference bench mark SJR 3, $170 \mathrm{ft}(52 \mathrm{~m})$ north of siphon No. 2, from 1959 to 1974. Figure 5 shows the subsidence trend of selected individual bench marks, and figure 6 shows the subsidence measured during $9 \mathrm{yr}$ of record at 10 bench marks in the vicinity of the San Jacinto reservoir site. The subsidence record of one of these bench marks, SJR 3, located near the extensometer installation, is the basis of many of the interpretive results of this study and is shown for an extended period of record in figure 8 and in amplified form from late August 1970 to early July 1974 in figure 9 .

\section{Water-level fluctuations}

Many water-level measurements by various agencies have been made in San Jacinto Valley. Few of the hydrographs, however, are of long duration or are definitive of head changes in specific depth zones.

Figure 7 shows the long-term trend of three observation wells near the San Jacinto reservoir site. These give a rough measure of the more than $100 \mathrm{ft}(30 \mathrm{~m})$ of head change in aquifers $300-600 \mathrm{ft}$ (90-180 m) deep in this part of the valley since 1946 and probably more than $125 \mathrm{ft}(38 \mathrm{~m})$ of decline since the early 1900's. The close correlation that exists between not only the 
long-term declining trend but also the seasonal fluctuations of water levels with the subsidence trend of bench mark SJR 3 and also with the extensometer records is apparent in figure 8.

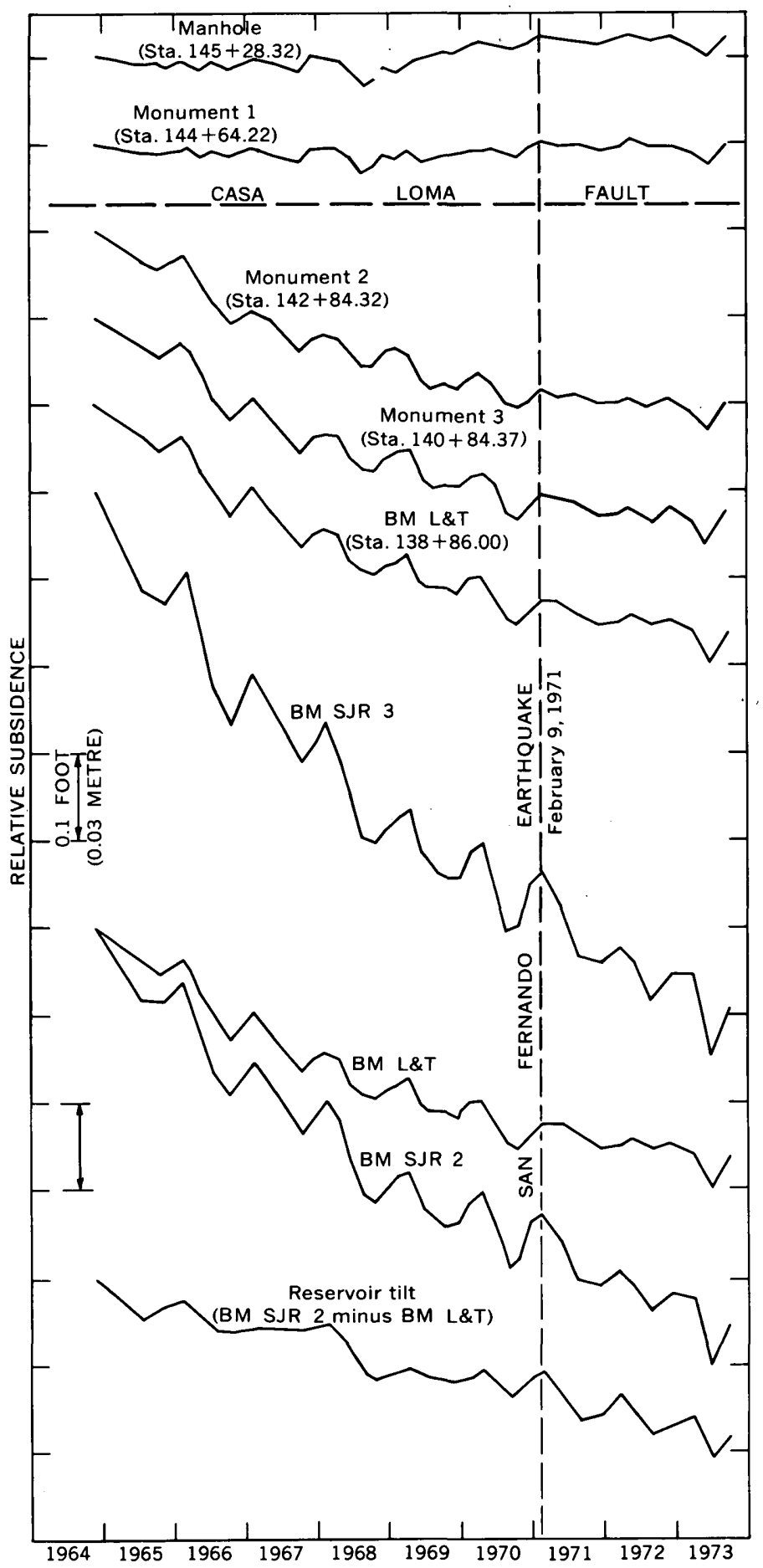

Figure 5.-Graphs showing relative subsidence of selected bench marks in the vicinity of the San Jacinto reservoir site, 1964-73. (Modified from graphs of the Metropolitan Water District of Southern California.)

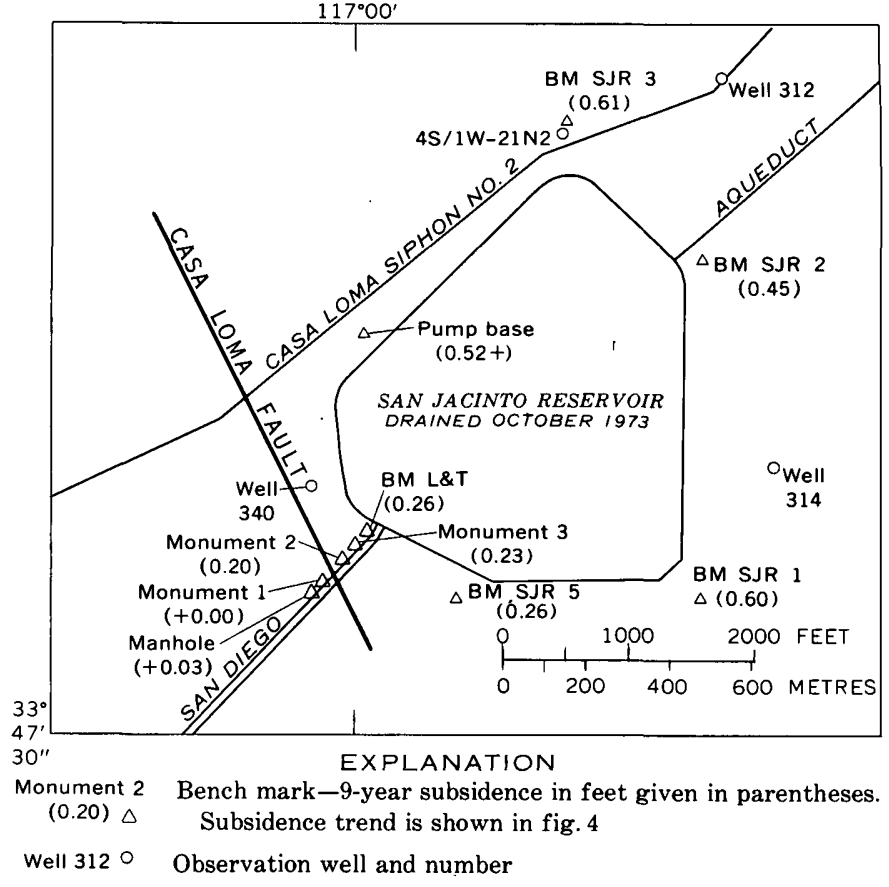

Figure 6.-Map showing location of selected observation wells and bench marks in the vicinity of the San Jacinto reservoir site, and the amount of measured subsidence, in feet, November 24, 1964, to October $1,1973$.

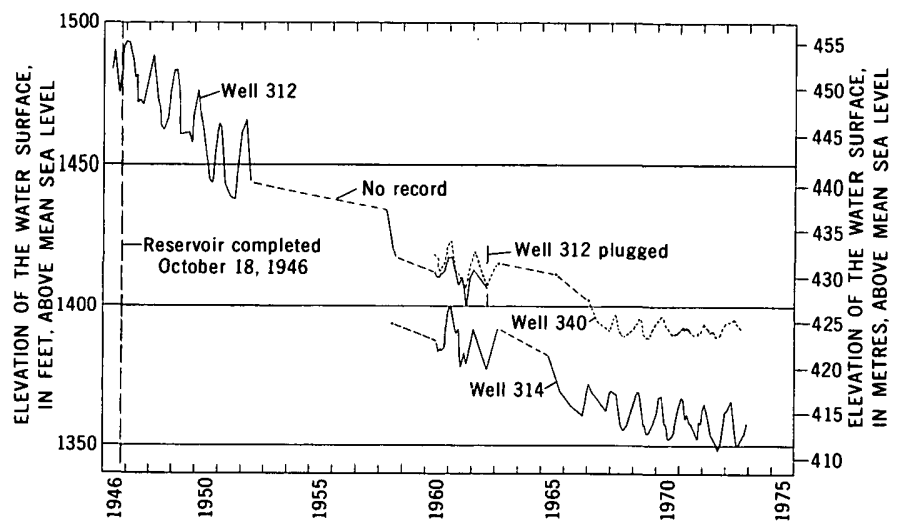

Figure 7.-Long-term hydrographs of observation wells near the San Jacinto reservoir site, 1946-73. (Modified from graphs of the Metropolitan Water District of Southem California.) 


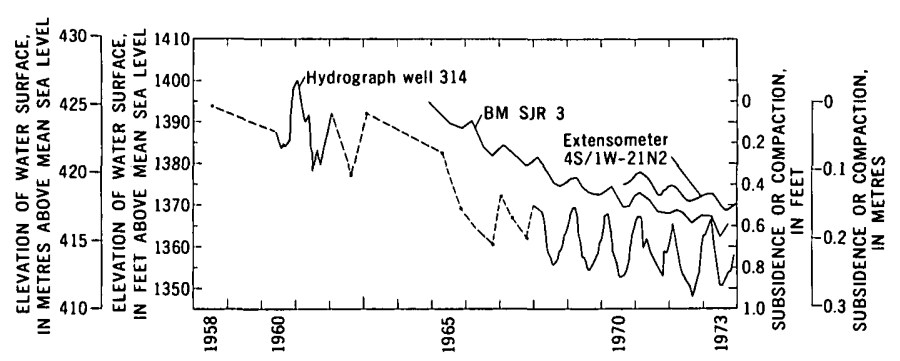

Figure 8.-Correlation of subsidence and compaction with water-level fluctuations near the San Jacinto reservoir site. (Lower two graphs modified from graphs of the Metropolitan Water District of Southern Califormia.)

Figure 9 shows at larger scale the record of waterlevel fluctuations from late August 1970 through June 1974 as measured in well $4 \mathrm{~S} / 1 \mathrm{~W}-21 \mathrm{~N} 2$, which monitors head changes in the 900 to $960-\mathrm{ft}(275-290-\mathrm{m})$ and 1,220 to 1,227-ft (372-374-m) depth zones (fig. 3). This hydrograph exhibits two features characteristic of a heavily pumped ground-water basin-an annual cyclic fluctuation with a seasonal amplitude of about $50 \mathrm{ft}(15 \mathrm{~m})$ and a general long-term downward trend of about $3 \mathrm{ft}(1 \mathrm{~m})$ per year. As shown by Lofgren $(1968)$, these confined head changes are a rough measure of changes in effective stress in the aquifer system-1 $\mathrm{ft}(0.3 \mathrm{~m})$ decline causing about $1 \mathrm{ft}(0.3 \mathrm{~m})$ of increase in effective stress ( $1 \mathrm{ft}$ of head equals 0.43 $\mathrm{lb} / \mathrm{in}^{2}$ or $\left.2,990 \mathrm{~Pa}\right)$ and a $1-\mathrm{ft}(0.3 \mathrm{~m})$ rise causing about $1 \mathrm{ft}(0.3 \mathrm{~m})$ of effective-stress decrease.

\section{Extensometer record of changes in formation thickness}

As demonstrated in numerous areas (Lofgren, 1968, 1975; Poland and Davis, 1969; Poland and others, $1975)$, fluctuations in the confined head of an artesian aquifer system produce changes in effective stress on the granular structure of the system which in turn cause changes in formation thickness. The magnitude of the thickness change is dependent on the effective- stress increase, the compressibility of the deposits, the thickness of the compressible beds, the time the increased stress has been applied, and possibly the rate and type of stress applied. It is also dependent on the past stress history-whether the increased stress is being applied for the first time or has been attained or exceeded previously.

Depending on the nature of the deposits, thickness changes may be (1) largely elastic, where stress and strain are proportional, independent of time, and reversible, or (2) principally inelastic, resulting from a rearrangement of the granular structure in such a way that the volume of the deposits is permanently decreased. In general, if the deposits are coarse sand and gravel, the change will be small and chiefly elastic and reversible, whereas if they contain fine-grained clayey beds, the change will be much greater and chiefly inelastic and permanent. Permanent compaction of the individual compressible beds results in a permanent subsidence of the land surface.

At well $4 \mathrm{~S} / 1 \mathrm{~W}-21 \mathrm{~N} 2$, the one location in San Jacinto Valley where companion water-level and extensometer records have been obtained, not only can the stress-strain parameters of the aquifer system be calculated but also the amount of settlement of the deposits below the 1,237-ft ( $377-\mathrm{m})$ extensometer anchor can be approximated. The upper graph of figure 9 shows the change in: thickness of the deposits to a depth of 1,237. ft $(377 \mathrm{~m})$ at well $4 \mathrm{~S} / 1 \mathrm{~W}-21 \mathrm{~N} 2$, from late August 1970 through June 1974 , as measured by the extensometer described earlier. The close correlation of this record with fluctuations of water level in the same well and also with changes in elevation of nearby bench mark SJR 3 is readily apparent. From these nearly $4 \mathrm{yr}$ of correlative records, several preliminary aquifer-system parameters have been calculated and tentative conclusions obtained. More definitive results await a longer period of records.

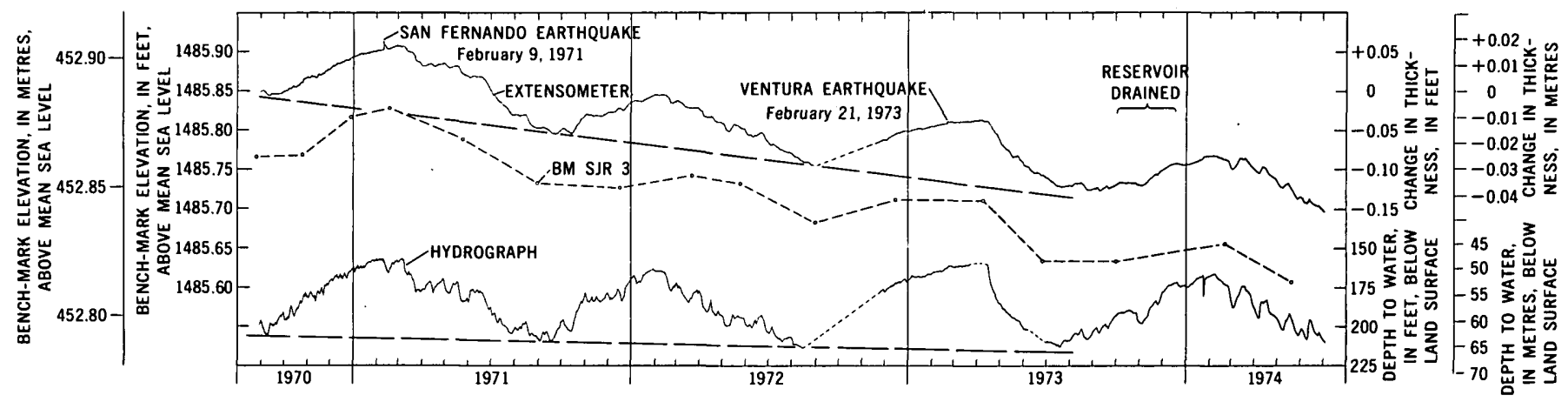

Fraure 9.-Change in aquifer-system thickness to a depth of $1,237 \mathrm{ft}(377 \mathrm{~m})$ and water-level fluctuations, as measured in well $4 \mathrm{~S} / 1 \mathrm{~W}-21 \mathrm{~N} 2$, and change in elevation of a nearby bench mark. 


\section{INTERPRETATION OF DATA}

Before extensive exploitation of the ground-water basin, wells flowed throughout much of the San Jacinto Valley (Mendenhall, 1905; Waring, 1919, fig. 1). Artesian heads in the producing aquifers in the vicinity of the San Jacinto reservoir site probably were more than $10 \mathrm{ft}(3 \mathrm{~m})$ above the land surface. As groundwater development continued, water levels were drawn down significantly. By 1960, heads in the confined aquifers had declined about $90 \mathrm{ft}(27 \mathrm{~m})$ (fig. 7 ), more in some of the aquifers than in others. By summer 1971 , the head in well $340(4 \mathrm{~S} / 1 \mathrm{~V}-29 \mathrm{H} 1)$ was about $130 \mathrm{ft}(40 \mathrm{~m})$, and in well $314(4 \mathrm{~S} / 1 \mathrm{~W}-28 \mathrm{~F} 1)$ was about $160 \mathrm{ft}(49 \mathrm{~m})$ below the initial flowing head. Most of the decline in these wells occurred after 1947 ; since that time the head decline has averaged 5 to $6 \mathrm{ft}(1.5-1.8 \mathrm{~m})$ per year in these wells. Since 1970 , the head in well $4 \mathrm{~S} / 1 \mathrm{~W}-21 \mathrm{~N} 2$ has fluctuated with a much greater seasonal amplitude, and in a depth range $50-100 \mathrm{ft}(15-30 \mathrm{~m})$ below the head in wells 314 and 340 , respectively, suggesting that the newer, deeper observation well is in more intimate contact with the heavy pumping of the area.

Leveling data indicate that historic subsidence has been much greater in the graben trough than on either side. Fett, Hamilton, and Fleming (1967, p. 30) noted 0.134 to $0.201 \mathrm{ft}(4.1$ to $6.1 \mathrm{~cm})$ of subsidence southwest of the Casa Loma fault (outside the graben) in the Hemet area between 1932-33 and 1963-64, whereas bench marks in the graben near San Jacinto subsided 1.024 and $1.125 \mathrm{ft}(31.2$ and $34.3 \mathrm{~cm})$ during this same period. Proctor (1962, p. 1294) reported as much as $2.34 \mathrm{ft}(71.3 \mathrm{~cm})$ of subsidence in the graben along the Casa Loma siphon No. 1 about 1,000 ft $(305 \mathrm{~m})$ east of the Casa Loma fault between 1939 and 1959 and little or no change for bench marks east and west of the graben. Assuming that downfaulting of the graben averaged $0.019 \mathrm{ft}(0.58 \mathrm{~cm})$ per year between 1933 and 1963 near San Jacinto, the $1.125 \mathrm{ft}(34.3 \mathrm{~cm})$ of measured subsidence would be roughly half due to tectonism and half due to compaction caused by declining water levels. Also, of the $2.34 \mathrm{ft}(71.3 \mathrm{~cm})$ of subsidence on the Casa Loma siphon No. 1 between 1939. and 1959 , about $0.38 \mathrm{ft}(12 \mathrm{~cm})$ or 16 percent would be due to tectonic downfaulting and $1.96 \mathrm{ft}$ $(60 \mathrm{~cm})$ due to water-level decline.

As shown in figure 4, the subsidence rate along Casa Loma siphon No. 2 is greatest in the vicinity of San Jacinto reservoir site and decreases abruptly toward the Casa Loma fault on the southwest and more gradually across the graben in the northeast direction. At the point of maximum subsidence along the siphon (fig. 4), the subsidence rate averaged about $0.09 \mathrm{ft}$ $(2.7 \mathrm{~cm})$ per year from 1959 to 1970 , whereas at bench mark SJR 3, near the extensometer site, the rate averaged $0.07 \mathrm{ft}(2.1 \mathrm{~cm})$ per year from 1959 to 1974 .

Observation well $314 \quad(4 \mathrm{~S} / 1 \mathrm{~W}-28 \mathrm{~F} 1)$ and bench mark SJR 3 are about the same distance northeast of the Casa Loma fault, and being roughly a half mile apart, probably together give an approximation of the stress-strain characteristics of the aquifer system in this part of the graben. Figure 8 shows the close correlation between both long-term and seasonal changes occurring at these sites. From fall 1964 to fall 1973 the water level in well $314(4 \mathrm{~S} / 1 \mathrm{~W}-28 \mathrm{~F} 1)$ declined $26 \mathrm{ft}$ $(8 \mathrm{~m})$ while bench mark SJR 3 subsided $0.57 \mathrm{ft}(0.17$ $\mathrm{m})$. Subtracting $0.17 \mathrm{ft}(0.052 \mathrm{~m})$ (representing 0.019 $\mathrm{ft}$, or $0.0058 \mathrm{~m}$, per year times $9 \mathrm{yr}$ ) of subsidence for tectonism, the residual $0.40 \mathrm{ft}(0.12 \mathrm{~m})$ of subsidence would be due to compaction of the water-bearing deposits. If entirely caused by $26 \mathrm{ft}(8 \mathrm{~m})$ of head decline, this would indicate a specific subsidence of $1.5 \times 10^{-2}$ (units of subsidence per unit of head decline).

Figure 9 shows the hydrograph of well $4 \mathrm{~S} / 1 \mathrm{~W}-$ $21 \mathrm{~N} 2$, the extensometer record of change in thickness of water-bearing deposits to a depth of $1,237 \mathrm{ft}$ ( 377 $m$ ) in the same well, and changes in elevation of nearby bench mark SJR 3 (fig. 6 ) during $4 \mathrm{yr}$ of comparable record. The extensometer and bench-mark graphs are the same data as that shown at a reduced scale in figure 8. Throughout this period, the extensometer record shows a most sensitive correlation with water-level changes. Even the minor water-level fluctuations are faithfully reflected in the extensometer record, in both the expansion limb and the compression limb of the record. Also, changes in elevation of mark SJR 3 closely parallel the extensometer graph even though the quarterly measurements of elevation sometimes miss the highs and lows of the seasonal cycles.

In general, the three graphs (fig. 9) evidence two characteristic types of changes-(1) a seasonal cyclic fluctuation that seems to correspond to the groundwater pumping pattern of the area, and (2) a longterm declining trend in which both the troughs and the crests are progressively lower each year (except for the 1973 water-level crest) apparently caused by pumping overdraft and permanent subsidence at this location. After careful study of these graphs, there is little question that (1) ground-water changes are responsible for most of the changes in thickness of the water-bearing deposits measured by the extensometer, and also (2) changes in thickness of these water-bearing deposits to a depth of $1,237 \mathrm{ft}(377 \mathrm{~m})$ are respon- 
sible for most of the land-surface changes during this period.

Comparison of the slopes of the straight lines drawn through the 1970, 1971, and 1972 troughs of the extensometer and water-level graphs (fig. 9), shows that a water-level decline of roughly $3.5 \mathrm{ft}(1.1 \mathrm{~m})$ per year caused about $0.044 \mathrm{ft}(1.34 \mathrm{~cm})$ of compaction per year. 'Thus, the specific compaction (Poland and others, 1972, p. 3) of the aquifer system at this site during these $3 \mathrm{yr}$ was $1.3 \times 10^{-2}$ (units of compaction per unit of increase in applied stress). During the subsequent water-level recovery each year, the aquifer system expanded in elastic response to a decrease in effective stress (Lofgren, 1968). The specific expansion during these recoveries decreased from $1.29 \times 10^{-3}$ (unit of expansion per unit of stress decrease) in 197071 , to $1.11 \times 10^{-3}$ in $1971-72,1.07 \times 10^{-3}$ in $1972-73$, and $0.95 \times 10^{-3}$ in $1973-74$. These parameters indicate that excess pore pressures in the slow-draining finegrained aquitards of the aquifer system are not completely dissipated each year and that there is measurable compaction of these beds during subsequent pumping seasons. Otherwise, the specific-expansion parameter would remain constant or tend to increase with time and probably would be only $2-5$ percent of the value of the specific compaction during virgin loading.

By subtracting the change in thickness of the upper $1,237 \mathrm{ft}(377 \mathrm{~m})$ of water-bearing deposits (upper graph, fig. 9) from the change in elevation of a surface bench mark (center graph, fig. 9), the change in elevation of the depth bench mark (extensometer anchor) can be calculated. Because both the thickness and the surface elevation are continually changing with time, this calculation can be made only at those times when the surface elevation is known and is only as accurate as is the surface elevation as determined by leveling. Because of the "floating" nature of bench marks in the graben trough and the several days normally required to complete a leveling survey from a stable reference bench mark, the measured elevations for bench mark SJR 3 (fig. 9) probably are no more accurate than $\pm 0.00 \mathrm{~s} \mathrm{ft}(0.15 \mathrm{~cm})$, even though the surveys by the Metropolitan Water District have been carefully read to thousandths of a foot.

The center graph of figure 10 shows with amplified scale the calculated change in elevation of the depth bench mark in well $4 \mathrm{~S} / 1 \mathrm{~W}-21 \mathrm{~N} 2$, as described above, and its relation to the ground-water and compaction trends. In the graph, zero change is taken as the first day the extensometer was recording. Because of inaccuracies in the measured values used in the calculations, the accuracy of the calculated elevations of the depth bench mark probably is less than $\pm 0.005 \mathrm{ft}$ $(0.15 \mathrm{~cm})$. Nevertheless, the indication of settlement occurring at depths below the 1,237-ft (377-m) anchor, exceeding the depth of most of the pumping in the valley, is significant. As shown, the calculated elevations of the depth bench mark are erratic; more erratic than can be reasonably explained. During the first $2 \mathrm{yr}$ of record, no definite trend is suggested in the depth bench-mark data. Since 1972, however, and possibly extending back to mid-1971, a definite downward trend is indicated. Depending on the straight line selected to best represent this downward trend, a settlement of from 0.010 to $0.019 \mathrm{ft}(0.30-0.58 \mathrm{~cm})$ per year is suggested by these data for the depth bench mark. Interestingly, the higher value is the same average settlement rate for the last $15,000 \mathrm{yr}$ as obtained from radiocarbon age determinations from buried

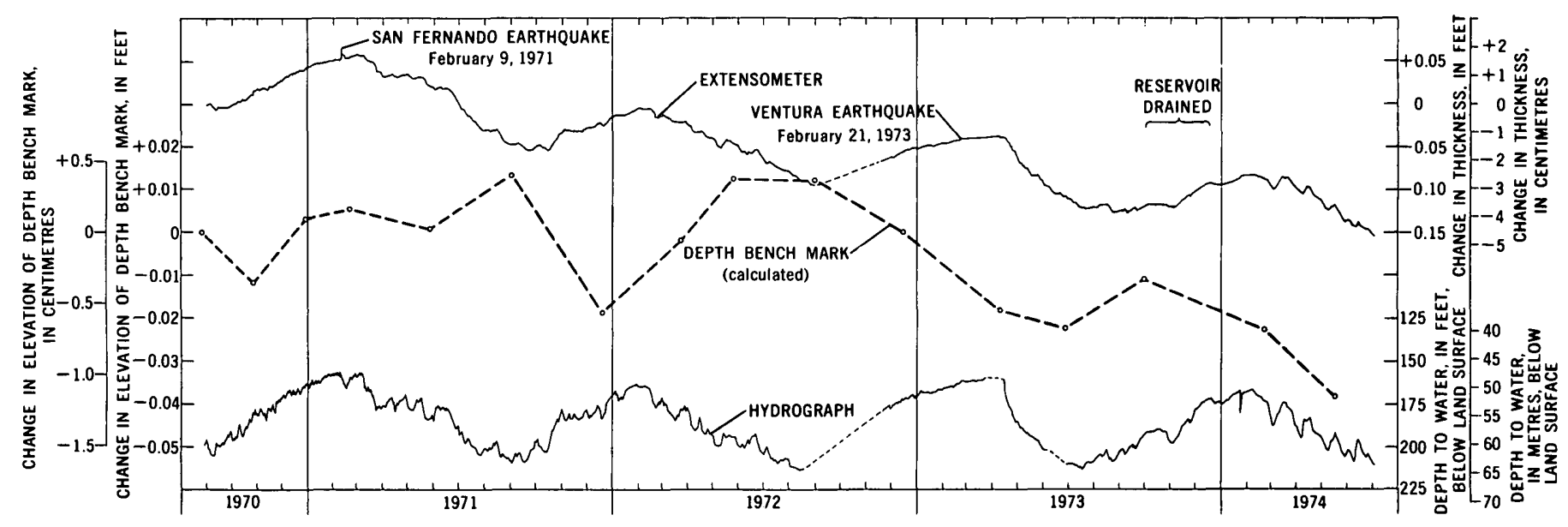

FIGURE 10.-Calculated change in elevation of the depth bench mark in well $4 \mathrm{~S} / 1 \mathrm{~W}-21 \mathrm{~N} 2$, and its relation to ground-water and extensometer trends, late August 1970-June 1974. 
wood samples collected from a nearby well. (Lofgren and Rubin, 1975).

Beoause neither the short-term variation nor the long-term downward trend in the elevation of the depth bench mark seem to correlate with either the water-level or the extensometer graphs, the cause of the suggested settlement is probably unrelated to changes in the aquifer system. Whether the ground movement of the February 9, 1971, San Fernando Valley earthquake or the February 21, 1973, Ventura earthquake, both of which were felt in the area and recorded by the extensometer, in any way relates to the suggested tectonic settlement of the depth bench mark is indeterminate. It is clear, however, that the draining of the San Jacinto reservoir site in October-December 1973 was not responsible for this subsidence at depth; (1) the downward trend began a year before, and has continued for more than 6 months since the draining of the reservoir, and also, (2) the unloading of the reservoir would tend to cause rebound rather than subsidence of the depth bench mark.

\section{REFERENCES CITED}

California Department Water Resources, 1959, Santa Ana River investigations: California Dept. Water Resources, Div. Resources Planning Bull. 15, 207 p., app.

Fet.t. J. I., Hamilton. D. H., and Fleming, F. A., 1967, Continuing surface displacements along the Casa Loma and San Jacinto faults in San Jacinto Valley, Riverside County, California: Eng. Geology [Sacramento, Calif.], v. 4, no. 1, p. 22-32.

Henderson, L. H., 1939, Detailed geological mapping and fault studies of the San Jacinto tunnel line and vicinity: Jour. Geology, v. 47, p. 314-324.

Lofgren, B. E., 1968, Analysis of stresses causing land subsidence, in Geological Survey research 1968: U.S. Geol. Survey Prof. Paper 600-B, p. B219-B225.
1975, Land subsidence due to ground-water withdrawal, Arvin-Maricopa area, California: U.S. Geol. Survey Prof. Paper 437-D.

Lofgren, B. E., and Rubin, Meyer, 1975, Radiocarbon dates indicate rates of graben downfaulting, San Jacinto Valley, California : U.S. Geol. Survey Jour. Research, v. 3, no. 1, p. $45-46$.

Mendenhall, W. C., 1905, Hydrology of San Bernardino Valley, California: U.S. Geol. Survey Water-Supply Paper 142, $124 \mathrm{p}$.

Poland, J. F., and Davis, G. H., 1969, Land subsidence due to withdrawal of fluids, in Varnes, D. J., and Kiersch, George, eds., Reviews in Engineering Geology, volume 2: Boulder, Colo., Geol. Soc. America, p. 187-269.

Poland, .J. F., Lofgren, B. E., Ireland, R. L., and Pugh, R. G., 1975, Land subsidence in the San Joaquin Valley as of 1972 : U.S. Geol. Survey Prof. Paper 437-H, 78 p.

Poland, J. F., Lofgren, B. E., and Riley, F. S., 1972, Glossary of selected terms useful in the studies of the mechanics of aquifer systems and land subsidence due to fluid withdrawal: U.S. Geol. Survey Water-Supply Paper 2025, 9 p.

Proctor, R. J., 1962, Geologic features of a section across the Casa Loma fault, exposed in an aqueduct trench near San Jacinto, Calif.: Geol. Soc. America Bull., v. 73, p. 12931296.

1974, New localities for fault creep in southern California-Raymond and Casa Loma faults [abs.] Geol. Soc. America Abs. with Programs, p. 238.

Sharp, R. V., 1967, San Jacinto fault zone in the Peninsular Ranges of Southern California: Geol. Soc. America Bull. v. 78 , no. 6 , p. $705-730$.

1972, Map showing recently active breaks along the San Jacinto fault zone between San Bernardino area and Borrego Valley, California: U.S. Geol. Survey Misc. Geologic Inv. Map I-675, sheet 2 of 3, scale 1:24,000.

Waring, G. A., 1919, Ground water in the San Jacinto and Temecula basins, California: U.S. Geol. Survey WaterSupply Paper 429, 113 p.

Woodford, A. O., Shelton, J. S., Doehring, D. O., and Morton, D. K., 1971, Pliocene-Pleistocene history of the Perris Block, southern California : Geol. Soc. America Bull., v. 82, no. 12, p. 3421-3448. 
Jour. Research U.S. Geol. Survey

Vol, 4, No. 1, Jan.-Feb. 1976, D. 19-25

\title{
EFFECTS OF AIR INJECTION AT PROMPTON LAKE, WAYNE COUNTY, PENNSYLVANIA
}

\author{
By JAMES L. BARKER, Harrisburg, Pa.
}

Prepared in cooperation with the U.S. Army Corps of Engineers Philadelphia District

\begin{abstract}
Air injected into the hypolimnion of Prompton Lake at a maximum rate of 210 cubic feet per minute ( 6 cubic metres per minute) during a 65-day period (July 27 to September 30,1973 ) produced the following results: (1) With cooler air temperatures prevailing, the mean subsurface temperature increased by $4.0^{\circ} \mathrm{C}$ compared with the same period in 1972 , (2) although chemical and thermal destratification was incomplete, 6 weeks of air injection increased the dissolved-oxygen concentration of the entire tropholytic zone to more than 4 milligrams per litre, (3) concentrations of nitrogen increased in the trophogenic zone during air injection, and (4) Anabaena flos-aquae attained cell concentrations. in excess of 4,500 per millilitre during air injection.
\end{abstract}

A 20-month investigation to determine the effects of compressed air injected into the hypolimnion of Prompton Lake, Wayne County, Pa., was conducted during 1972 and 1973 in cooperation with the U.S. Army Corps of Engineers, Philadelphia District. A systematic sampling program included data collection prior to, during, and after air injection.

Artificial aeration by compressed-air injection to destratify reservoirs and lakes is highly desirable according to many water users. Stratification often causes deteriorated potable water quality, corrosive and anaerobic conditions, increased evaporation rates, and, in eutrophic or mesotrophic waters, an oxygen deficit that leads to the re-solution of nutrients that maintain high populations of nuisance organisms.

The reduotion of nuisance populations of organisms, particularly blue-green algae, as a benefit of artificial destratification of lakes and reservoirs was measured by Lackey (1971) and Robinson and others (1969). Destratification favors algal species that do not have unique distributions in stratified lakes and those species that normally sink rapidly. Therefore, depending upon the species present in the lake, increases or decreases in algal biomass may result from destratification. Hooper and others (1952) and Fast and others (1973), for example, found increases in the standing crop of blue-green algae, and Malueg and others (1971) reported a decrease in the biomass.

In this study, compressed air was injected into the the hypolimnion in an effort to cause upwelling of cold water until the lake was isothermal, or nearly so, and to eliminate the oxygen deficit. The effects of destratification and aeration on the algae, physiochemical properties, and nutrients were measured.

\section{LAKE DESCRIPTION}

Prompton Lake is located in the west-central part of Wayne County adjacent to the town of Prompton in the glaciated section of northeastern Pennsylvania. The lake was formed in 1960 by the construction of a dam on the West Branch Lackawaxen River.

Prompton is a 280-acre (113.4-ha) impoundment that has a maximum depth of $39 \mathrm{ft}(11.9 \mathrm{~m})$, a normal pool capacity of 3,400 acre-ft $\left(4.19 \mathrm{hm}^{3}\right)$, and a mean depth of $12.1 \mathrm{ft}(3.7 \mathrm{~m})$. The lake receives the drainage from a $60 \mathrm{mi}^{2}\left(155.4 \mathrm{~km}^{2}\right)$ basin and, at a summer base-flow discharge of $20 \mathrm{ft}^{3} / \mathrm{s}\left(0.57 \mathrm{~m}^{3} / \mathrm{s}\right)$, has a theoretical maximum retention time of 85 days.

The basin is rural, with agriculture as the leading industry. The topography of the basin is characteristic of a glaciated terrain with rounded hills, U-shaped valleys, and numerous small lakes and marshes. The soils of the basin are formed upon shales and sandstones of the Catskill Formation, of Devonian age.

Water quality in Prompton Lake is good. The water is slightly alkaline and is classified as a calcium bicarbonate type with bicarbonate alkalinity of $27 \mathrm{mg} / \mathrm{l}$, carbonate hardness of $28 \mathrm{mg} / \mathrm{l}$, and dissolved solids of $45 \mathrm{mg} / \mathrm{l}$.

Thermal and chemical stratifications depend upon residence time and generally exist in relatively weak states in Prompton Lake during the June-September 
period. Dissolved oxygen is subject to depletion below a depth of $13 \mathrm{ft}(4.0 \mathrm{~m})$. Specific conductance and $\mathrm{pH}$ values in the bottom water indicate mineralization under anaerobic conditions.

Plankton samples suggest a biologically healthy lake, dominated by Chrysophyta or diatoms. Bluegreen algae occasionally reach nuisance concentrations in the late summer under favorable climatic conditions. Aquatic weeds have been prevalent but presented no problems in 1974.

\section{METHODS}

A systematic sampling program was conducted at Prompton Lake during a pre-aeration period (May 1972-July 1973), an aeration period (July 1973October 1973), and a post-aeration period (October 1973-December 1973). Six sampling stations were established, four within the lake and one each at the inflow and outflow stations (fig. 1). The four lake sites were marked with buoys. The outflow station is a surface-water gaging station equipped with a continuousstage recorder.

Temperature and dissolved oxygen were measured in place with a thermistor thermometer and polarographic oxygen probe. Transparency was determined with a standard 7.9-in $(20-\mathrm{cm})$ black-and-white Secchi disk and a calibrated metal sounding line.

Phytoplankton sampling consisted of filtering 1,100 $\mathrm{ml}$ of water (collected from $1.5 \mathrm{ft}$ or $0.5 \mathrm{~m}$ below the surface, mid-depth, and $3 \mathrm{ft}$ or $1 \mathrm{~m}$ above the bottom) through a Wisconsin-style plankton net of No. 20 nylon bolting cloth at each of the four lake-sampling stations (stations $2,3,4$, and 5 in fig. 1 ). The concentrate was then preserved in a merthiolate solution (Weber, 1966) and counted in a Sedwick-Rafter counting cell.

One-litre samples of raw water were collected from $1.5 \mathrm{ft}(0.5 \mathrm{~m})$ below the surface at the same four stations and from $3 \mathrm{ft}(1 \mathrm{~m})$ above the bottom at stations 3,4 , and 5 . These samples were analyzed for constituents in the nitrogen cycle and for dissolved and total phosphorus. Additional samples were collected from station 5 for chlorophyll $a$ and total organic carbon analyses. Samples were collected once a month and more frequently during much of the growing season (June-October). Daily temperature profiles were collected at the four lake stations from July 26 to August 15, 1973.

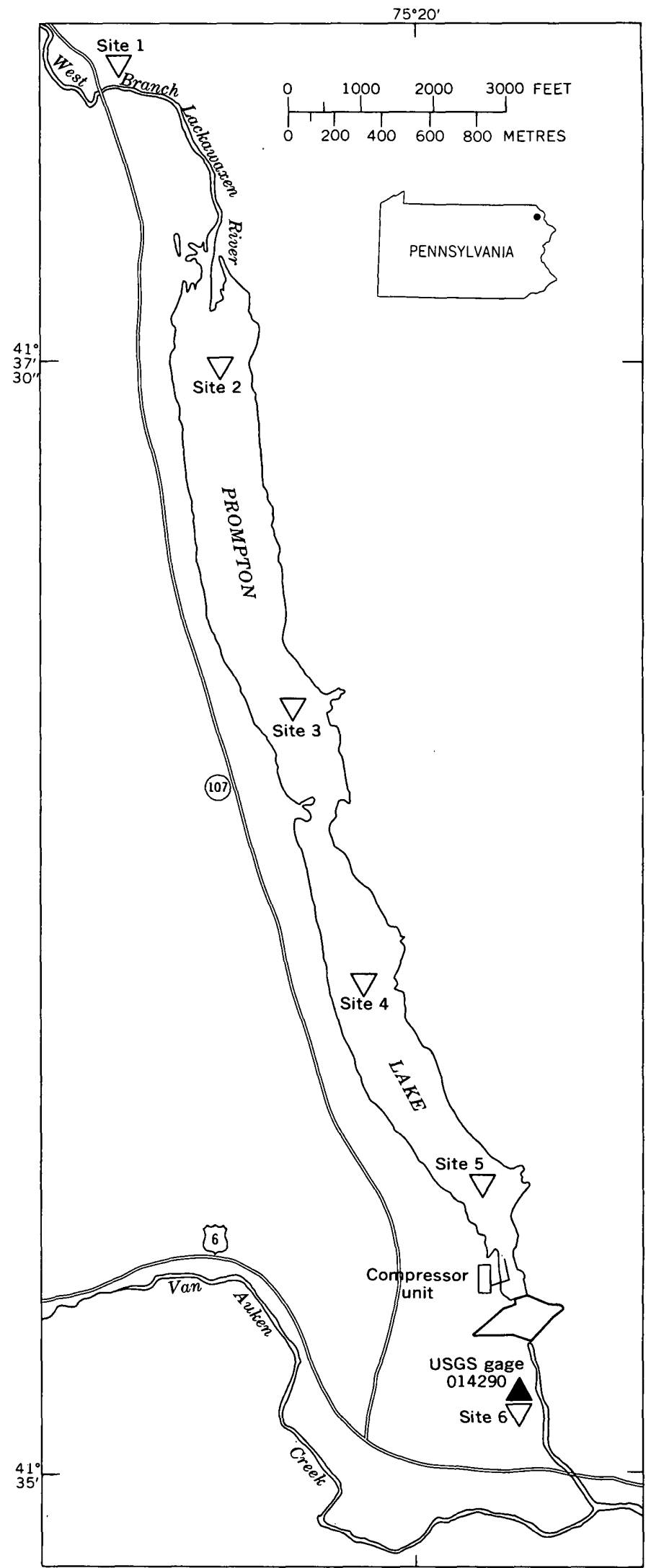

Figure 1.-Data-collection stations in Prompton Lake drainage basin. 
Chemical analyses were completed according to methods presented in Rainwater and Thatcher (1960), Slack and others (1973), or Brown and others (1970).

\section{DESCRIPTION AND OPERATION OF AERATION SYSTEM}

Compressed air was delivered to the primary manifold system at a pressure of 70 to 100 pound-force per square inch gage $\left(4.92\right.$ to $\left.7.03 \mathrm{kgf} / \mathrm{cm}^{2}\right)$ by a gasolinedriven compressor with an operating displacement of $210 \mathrm{ft}^{3} / \mathrm{min}\left(6 \mathrm{~m}^{3} / \mathrm{min}\right)$. The five-place manifold system, anchored in the deepest part of the lake, released air to a low-pressure diffusion tube in sufficient volume and pressure (about $30 \mathrm{lbf} / \mathrm{in}^{2} \mathrm{~g}$ or $2.11 \mathrm{kgf} / \mathrm{cm}^{2}$ ) to overcome the hydrostatic head. A sketch of the dualpressure air-diffusion system is shown in figure 2.

Air injection began on July 27, 1973, and ran almost continuously until August 16, 1973. From August 17 until August 30, 1973, the compressor ran on a 16-h schedule, starting at about 1000 hours and continuing until about 0200 hours. A 24-h schedule was resumed from August 31 until September 13, 1973. A 16-h schedule was resumed again on September 14, until the compressor was shut down on October 1, 1973.

\section{RESULTS \\ Temperature}

Temperature profiles taken on July 27,1972 (fig. 3), indicated Prompton Lake was becoming stratified de-
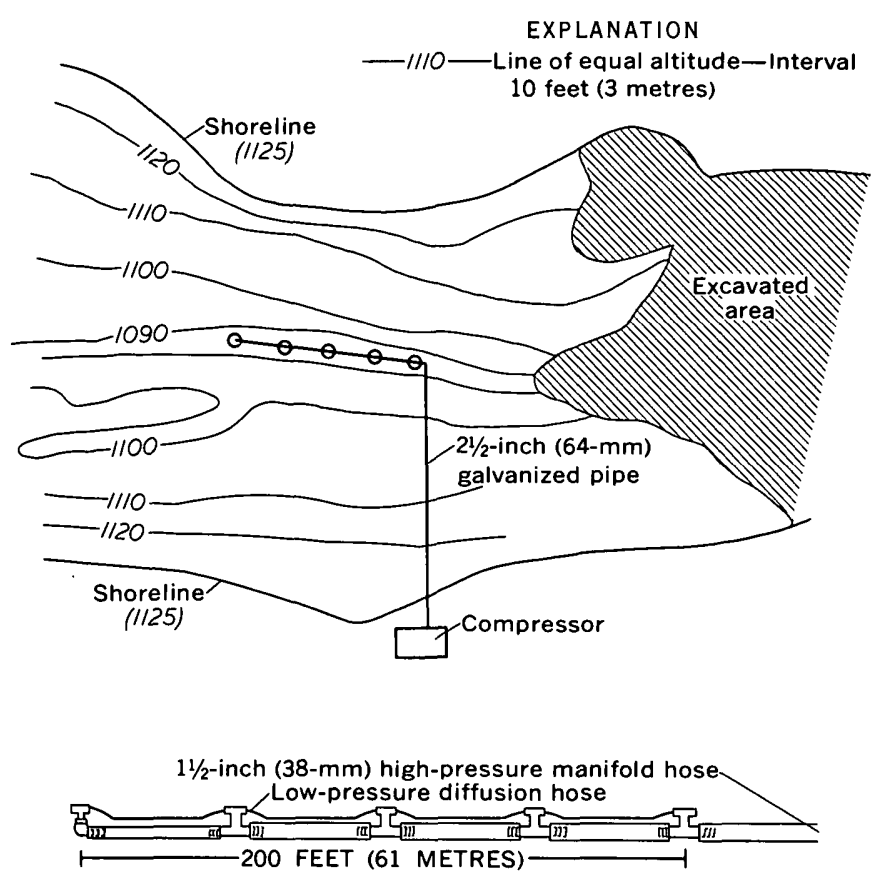

Fratra 2.-Dual-pressure air-diffusion system and detail of system (below). spite tropical storm Agnes and other heavy rains and runoff in May, June, and early July. Figure 3 shows the thermal stratification that began at a depth of 10 ft $(3 \mathrm{~m})$; however, the stratification was dissipated by several rainstorms in August, and significant thermal stability did not return for the remainder of the summer season. Observed maximum water temperatures during the summer of 1972 were $24.5^{\circ} \mathrm{C}$ at the surface and $14.0^{\circ} \mathrm{C}$ at the bottom.

Prior to beginning air injection on July 27, 1973, thermal characteristics were similar to those for the same period in 1972. A major runoff on June 23, 1973, had the effect of destroying thermal stability by displacing and mixing the lake water; however, by the end of July, thermal stability was fairly well established.

Some effects of air injection evident from figure 3 were a warming of subsurface waters and the reduction of thermal stability. Minimum temperatures in the bottom waters increased by $1.0^{\circ} \mathrm{C}$ compared with the same date in 1972 (table 1), while temperatures at mid-depth of 16 to $26 \mathrm{ft}(5.0-8.0 \mathrm{~m})$ averaged $4.5^{\circ} \mathrm{C}$

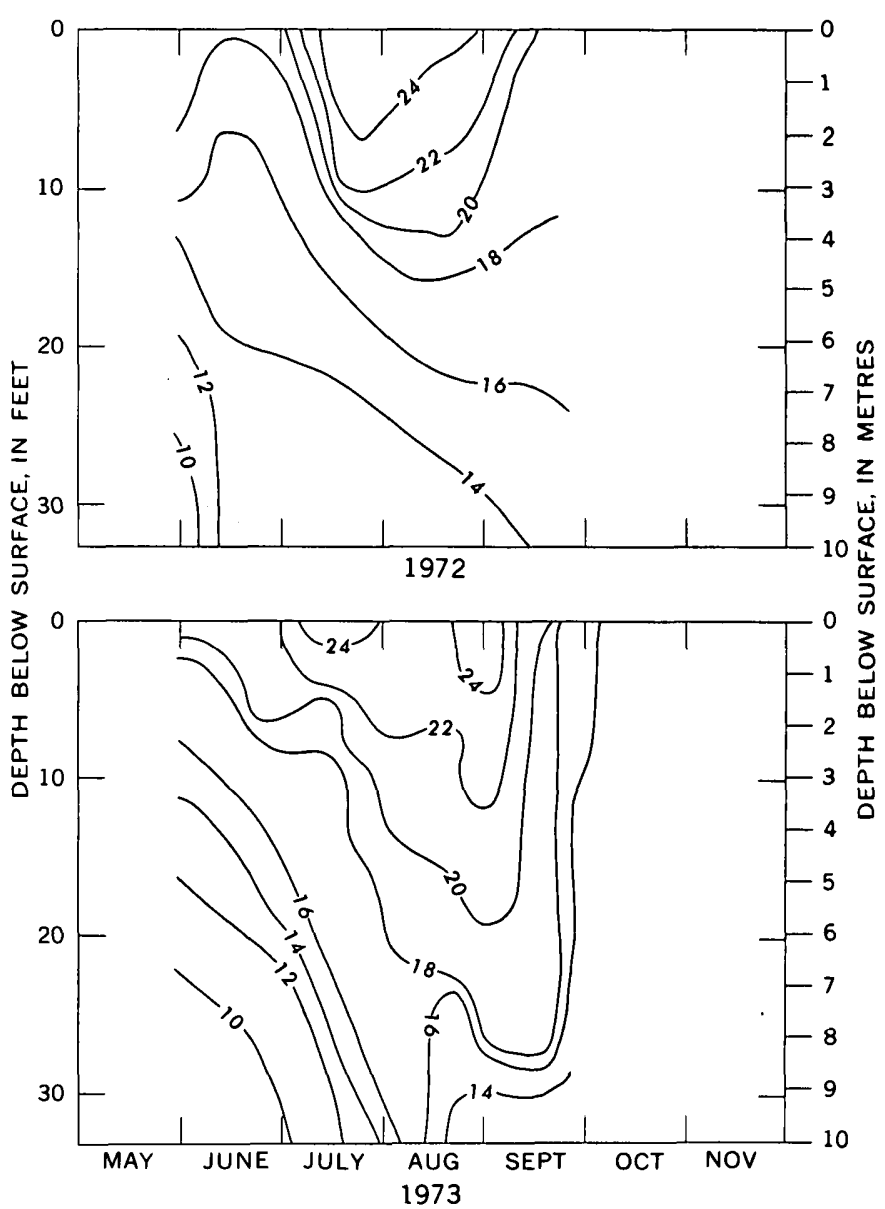

Fraure 3.-Isotherms, in degrees Celsius, at station 4 in Prompton Lake. 
warmer than those observed during 1972. The increased temperature of the subsurface strata was probably the result of a net increase in absorption of solar radiation due to the induced circulation.

TABLE 1.-Comparison of temperature versus depth for station 4, August 23, 1972 and 1973

\begin{tabular}{ccc}
\hline \multirow{2}{*}{$\begin{array}{c}\text { Depth } \\
\text { (feet) }\end{array}$} & \multicolumn{2}{c}{ Temperature $\left({ }^{\circ} \mathbf{C}\right)$} \\
\cline { 2 - 3 } & August 23, 1972 & August 23, 1973 \\
\hline 0 & 23.0 & 23.0 \\
3.3 & 22.0 & 22.5 \\
6.6 & 22.0 & 22.0 \\
9.8 & 20.5 & 22.0 \\
13.1 & 19.5 & 22.0 \\
16.4 & 18.0 & 22.0 \\
19.7 & 17.5 & 22.0 \\
23.0 & 15.5 & 20.5 \\
26.3 & 14.5 & 18.5 \\
29.0 & 13.5 & 14.0 \\
32.8 & 12.5 & 13.5 \\
\hline
\end{tabular}

Air injection failed to produce isothermal conditions anywhere in the lake despite 65 days of pumping at Prompton Lake. Apparently, isothermy can only be approached and not completely achieved under conditions of a high rate of heating and a low rate of mixing. Since efficiency decreases as isothermy is approached, it would require an unrealistically large input of work to achieve and maintain isothermy.

\section{Chemical Quality}

\section{Nutrients}

Analyses for total nitrogen and phosphorus and specific conductance of the surface and bottom waters prior to air injection indicate that, as with the thermal properties, the lake displayed a moderate degree of stratification both summer and winter.

The period of air injection resulted in the general destratification of nutrients. The sample data (fig. 4) indicate that surface and bottom specific-conductance values tended toward uniformity about 2 weeks after air injection began, whereas, nitrogen and phosphorus took about 3 and 5 weeks, respectively, to destratify. The lake did not chemically restratify after termination of air injection on September 30, 1973.

The net result of destratification was somewhat higher concentrations of nitrogen in the trophogenic zone during the growing season (June-October). Total nitrogen increased during the air-injection period from a mean of 0.43 in 1972 to $0.56 \mathrm{mg} / 1$ in 1973 . The largest increases were in the concentrations of ammonia nitrogen and organic nitrogen; the increases were probably the result of the upwelling of nutrientrich hypolimnetic water.
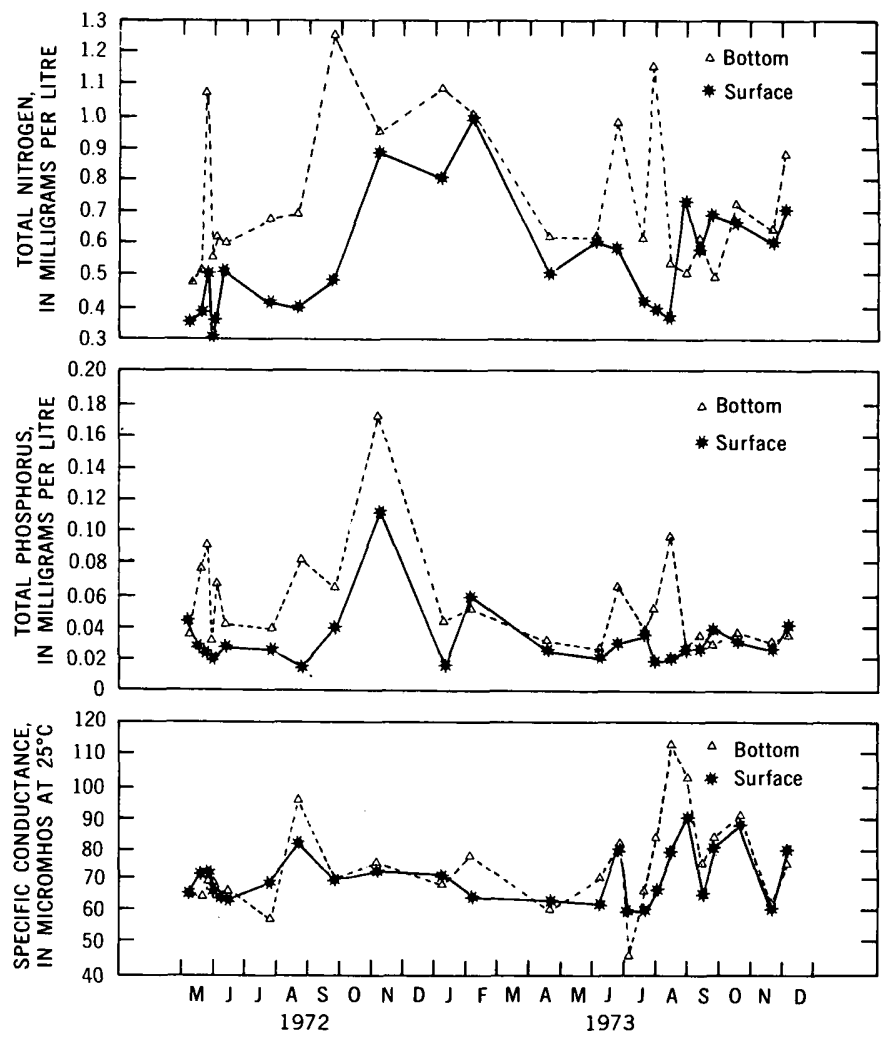

Figure 4.-Average total nitrogen, total phosphorus, and specific conductance in Prompton Lake during a pre-aeration period (May 1972-July 1973), an aeration period (July 1973October 1973), and a post-aeration period (October 1973December 1973 ).

In overall decrease in total phosphorus at the bottom was measured during and after air injection. Although the phosphorus cycle is complex, the decrease may be explained by the oxidized microzone above the sediment that would inhibit the release of phosphorus. As pointed out by Fitzgerald (1970) and others, sediment can strip phosphorus from lake water under aerobic conditions. Phosphorus concentrations at the surface remained at about the same level but supported an increase in biomass.

\section{Dissolved oxygen}

Prior to air injection in late July 1973, the dissolvedoxygen regimes during 1973 were quite similar (fig. 5) to those of 1972. Oxygen deficits began at a depth of $6.6 \mathrm{ft}(2.0 \mathrm{~m})$ and reached depletion at a depth of 16.4 $\mathrm{ft}(5.0 \mathrm{~m})$. Maximum concentrations occurred near the surface. After 1 week of air injection the hypolimnion was increasing in oxygen concentration. After 6 weeks of aeration the entire hypolimnion contained more than $4 \mathrm{mg} / \mathrm{l}$ of oxygen. Air injection had no perceptible effect upon epilimnetic dissolved-oxygen concentrations. The irregularity of the dissolved- 

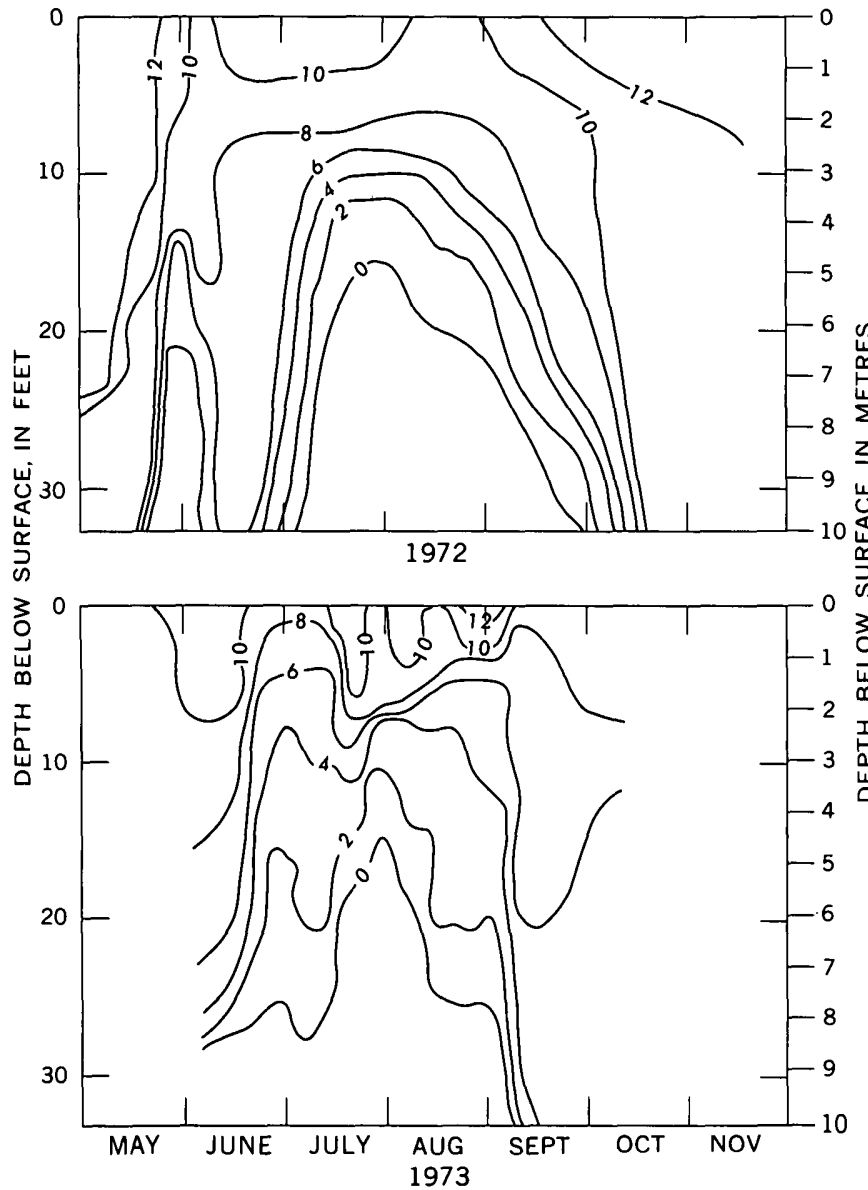

Figure 5.-Dissolved oxygen at station 4 in Prompton Lake. Lines indicate equal dissolved-oxygen concentration in milligrams per litre.

oxygen lines in 1973 is probably due to the greater frequency of sampling.

\section{Phytoplankton}

Chrysophyta, principally Asterionella and Tabellaria, were dominant during the 14-month sampling period prior to air injection. During November 1972, the blue-green alga, Aphanizomenon, became dominant for a short period and during July 1973 another bluegreen alga, Anabaena, was dominant (table 2). Mean cell counts ranged from 3 to $300 / \mathrm{ml}$ in 1972 (fig. 6). The types of algae and their abundance followed the general model for a mesotrophic lake, where diatoms are dominant most of the year but green algae increase in abundance in the summer and blue-green algae are dominant in late summer and early autumn.

Interpretation of the phytoplankton data was complicated by several events during the summer of 1972 . A series of rainstorms from May to early July physically disrupted the lake ecosystem and, no doubt, reduced the number of plankton. Further, an application

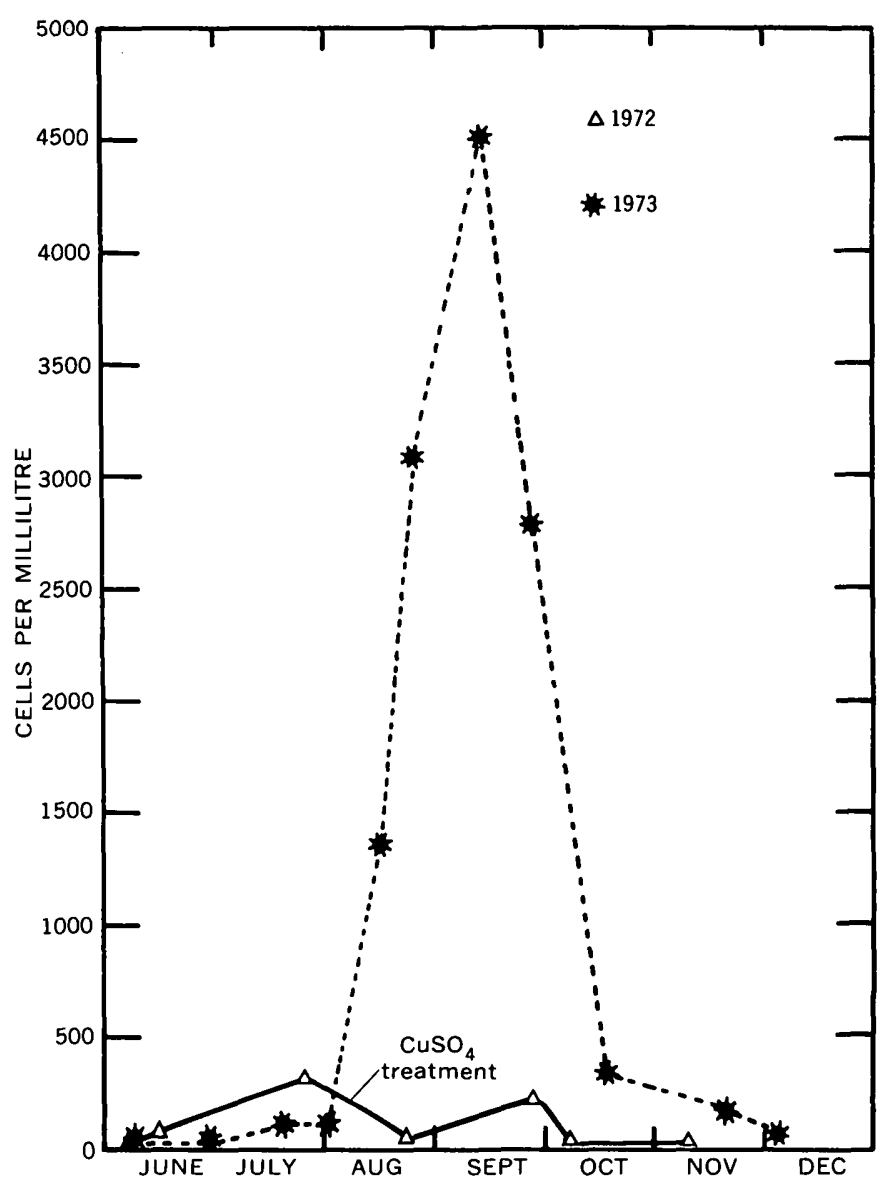

Figure 6.-Mean phytoplankton density in Prompton Lake.

of $700 \mathrm{lb}$ of copper sulfate to the lake on August 16, 1972, had a catastrophic effect upon the phytoplankton and may have been the prime reason the lake had a low plankton density for the remainder of the growing season.

After the beginning of air injection on July 27, 1973, the phytoplankton population became dominated by Anabaena flos-aquae, to the near exclusion of all other types (table 2). Average cell counts ranged from $113 / \mathrm{ml}$ on August 1 to more than 4,500/ml on September 13. The high density of Anabaena persisted until air injection ended on September 30.

Vertical distribution of phytoplankton (table 3 ) did not appear to be greatly affected by the air-injection program. Total cell counts during the control and treatment period indicate a high proportion of cells in the bottom water due to mixing and (or) settling. Longitudinal distribution of phytoplankton (table 4) also appears to have been unaffected by the treatment.

The post-injection period is best characterized as a period of die-off of Anabaena and a return to lower densities of indigenous genera of diatoms. One diatom, Fragilaria, sp., had not been observed prior to air injection. 
TABLE 2.-Dominant phytoplankton genera inhabiting Prompton Lake

[Total cell-count values represent mean concentrations of cells per millilitre. A genera was considered a dominant if it comprised $>15$ percent of the standing crop; parenthetic values are percent of standing crop ]

\begin{tabular}{|c|c|c|}
\hline Date & $\begin{array}{l}\text { Total } \\
\text { cell } \\
\text { count }\end{array}$ & Dominant phytoplankton genera \\
\hline \multicolumn{3}{|l|}{1972} \\
\hline May $10 \ldots$ & 12 & Synura (33.3), Asterionella (25). \\
\hline May 18 & 10 & Mallomonas (20), Cryptomonas (20). \\
\hline May 24 & 8 & Synedra (18). \\
\hline May 31 & $\mathbf{3}$ & $\begin{array}{l}\text { Navicula (33.3), Syncdra (33.3), Tabel- } \\
\quad \text { laria (33.3). }\end{array}$ \\
\hline June 7 & 15 & Synechococcus (66.6). \\
\hline June 14 & 73 & Asterionella (55), synechococcus (41). \\
\hline July 27 & $\mathbf{3 0 0}$ & Asterionella (73), Anabaena (15). \\
\hline Aug. 23 ...- & 57 & Tabellaria (59.6). \\
\hline Sept. 27 & 217 & Tabellaria (69.5), Anabaena (23.0). \\
\hline Nov. 9 & 19 & Aphanizomenon (94.7). \\
\hline \multicolumn{3}{|l|}{$197 \mathrm{~s}$} \\
\hline Apr. 18 & 12 & $\begin{array}{l}\text { Asterionella }(39), \text { Dinobryon } \\
\text { Navicula }(16) .\end{array}$ \\
\hline June 6 & $\mathbf{5}$ & Asterionella (45), Tabellaria (37). \\
\hline June $27 \ldots$ & $\mathbf{3 4}$ & Tabellaria (68). \\
\hline July 19 & 115 & Anabaena (86). \\
\hline Aug. 1 & 113 & Anabacna (93). \\
\hline Aug. 15 -.-- & 1,344 & Anabaena (85). \\
\hline Aug. 30 & 3,071 & Anabaena (99). \\
\hline Sept. 13 & 4,504 & Anabaena (99). \\
\hline Sept. 27 & 2,803 & Anabacna (99). \\
\hline Oct. $18 \ldots$ & 422 & Anabaena (93). \\
\hline Nov. 20 & 170 & $\begin{array}{l}\text { Fragilaria (17), Tabellaria (25), Melo- } \\
\quad \text { sira }(26), \text { Anabaena }(28) .\end{array}$ \\
\hline Dec. 4 -..- & 68 & Fragilaria (34), Tabellaria (47). \\
\hline
\end{tabular}

TABLE 3.-Vertical distribution of phytoplankton, in cells per millilitre, in Prompton Lake

\begin{tabular}{|c|c|c|c|}
\hline Date & Surface & Mid-depth & Bottom \\
\hline \multicolumn{4}{|l|}{1972} \\
\hline May 10 & 12 & 10 & 7 \\
\hline May $18 \ldots$ & 10 & 51 & 11 \\
\hline May $24 \ldots$ & 8 & 14 & 54 \\
\hline May 31 & 3 & 109 & 9 \\
\hline June 7 & 15 & $\mathbf{5}$ & 32 \\
\hline June 14 & 73 & 12 & 9 \\
\hline July 27 & 300 & 243 & 245 \\
\hline Aug. $23 \ldots$ & 57 & 97 & 49 \\
\hline Sept. 27 & 217 & 217 & 44 \\
\hline 1975 & & & \\
\hline Apr. 18 & 12 & 11 & 9 \\
\hline June 6 & $\mathbf{5}$ & 8 & 6 \\
\hline June 27 & 34 & 17 & 8 \\
\hline July 19 & 115 & 57 & 19 \\
\hline \multicolumn{4}{|l|}{ Air-injected period : } \\
\hline Aug. 1 & 113 & 34 & 9 \\
\hline Aug. 15 & 1,344 & 463 & 222 \\
\hline Aug. 30 & 3,071 & 990 & 117 \\
\hline Sept. 13 & 4,504 & 4,439 & 2,257 \\
\hline Sept. 27 & 2,803 & 78 & 64 \\
\hline Oct. 18 & 442 & 380 & 301 \\
\hline
\end{tabular}

TABLE 4.-Longitudinal distribution of phytoplankton, in cells per millilitre in Prompton Lake in 1979

\begin{tabular}{|c|c|c|c|c|}
\hline \multirow{2}{*}{ Date } & \multicolumn{4}{|c|}{ Station } \\
\hline & 2 & 3 & 4 & 5 \\
\hline Aug. 15 & 590 & 430 & 1,100 & 1,900 \\
\hline Aug. 30 & 2,900 & 4,000 & ---- & 2,100 \\
\hline Sept. 13 & 4,800 & 5,700 & 3,600 & 4,200 \\
\hline Sept. 27 & 4,600 & --- & 4,300 & 1,300 \\
\hline
\end{tabular}

It is difficult to say for certain what, if any, effect air injection had upon the abundance of phytoplankton. During the pre-aeration period the lake was subjected to an application of algicide; had the algicide not been applied, the lake would have experienced a growth of algae that might well have been similar in proportion to that of August-September 1973. Although it is not known whether air injection stimulated or retarded blue-green algal growth, it definitely did not prevent its growth.

Anabaena flos-aquae, a common nuisance bluegreen alga, has been observed by some earlier researchers (Knoppert and others, 1970; Lackey, 1973) to increase during destratification. If Anabaena and other blue-green algae are insensitive to forced summer circulation, then the benefits of this type of lake management program would be seriously lessened where bluegreen algae characteristically reach bloom proportions.

\section{Transparency}

Transparency during the pre-injection period ranged from 174 in (442 cm) on August 23, 1972, to 12 in (30 $\mathrm{cm})$ on November 12, 1972. The data indicate that the background transparency results in Secchi disk values of from 50 to 70 in $(127 \mathrm{~cm}-178 \mathrm{~cm})$. An abrupt increase in transparency during the middle of August 1972 corresponded to the copper sulfate treatment on August 16, 1972, that effectively killed the phytoplankton. Within 5 weeks after the copper treatment the transparency decreased at all stations to less than 40 in $(102 \mathrm{~cm})$ and by November 9 (autumn overturn) to less than 30 in $(76 \mathrm{~cm})$.

Air injection did not appear to have any significant effect upon transparency. The low transparency at the end of August 1973 corresponded well with the period of the blue-green algal bloom. A region of low transparency containing suspended detritus from the depths of the lake was observed in the vicinity of the "boils" surrounding the air.

\section{CONCLUSIONS}

The results of the present study suggest that injection of compressed air into the hypolimnion of a $35-\mathrm{ft}$ (10.6-m) deep lake will significantly increase subsurface water temperatures with little effect upon the surface water outside the area of the "boil." Thermal destratification was approached after 6 weeks of pumping compressed air into the hypolimnion, but isothermy was never completely achieved and perhaps was not possible under the limitations of the system.

Chemical destratification was achieved to a great degree within 2 to 5 weeks after air injection began. 
The net results was higher concentrations of nitrogen in the trophogenic zone. Phosphorus concentrations were more difficult to evaluate. Perhaps the greatest positive effect was that dissolved-oxygen concentrations were increased within the hypolimnion. Within 6 weeks the entire deep-water area contained more than $4 \mathrm{mg} / \mathrm{l}$ of oxygen, and thereby the volume of the lake suitable for aerobic life was increased by 12 percent. The epilimnetic dissolved-oxygen cencentrations were not appreciably influenced by air injection.

It was difficult to evaluate the effects of air injection upon the phytoplankton owing to the environmental disruptions during the pre-injection period. However, there was no evidence that phytoplankton populations were reduced as a result of air-induced circulation as suggested by studies at other lakes. Hypolimnetic aeration did not appear to have any significant effect upon transparency.

The objective of controlling the growth of bluegreen algae by cooling the waters of the trophogenic zone was not met. The reasons for the lack of algal control are not clear but are probably associated with lake configuration, insufficient depth (that is, cold water), and insufficient circulation to overcome solar heating and thermal stability of the epilimnion.

\section{REFERENCES CITED}

Brown, Eugene, Skougstad, M. W., and Fishman, M. J., 1970, Methods for collection and analysis of water samples for dissolved minerals and gases: U.S. Geol. Survey Techniques Water-Resources Inv., book 5, chap. A1, $160 \mathrm{p}$.

Fast, A. W., Moss, Brian, and Wetzel, R. G., 1973, Effects of artificial aeration on the chemistry and algae of two Michigan lakes: Water Resources Research, v. 9, no. 3, p. 624-647.
Fitzgerald, George, 1970, Aerobic lake muds for the removal of phosphorus from lake waters: Limnology and Oceanography, v. 15, no. 4, p. 550-555.

Hooper, F. F.. Ball, R. C., and Tanner. H. A., 1952, An experiment in the artificial circulation of a small Michigan lake : Ail. Fish. Soc. Trans., v. 82, 20 p.

Knoppert, P. L.. Rook. J. J., Hofker, 'Tj., and Oskam, G., 1970. Destratification experiments at Rotterdam: $\Lambda \mathrm{m}$. Water Works Assoc. Jour., v. 62. p. 448-454.

Lackey, R. T.. 19ז1, Effects of artificial destratification of a lake ecosystem: Colorado Div. Game, Fish, and Parks, Jingell-Johnson Job Completion Rept., Colorado Proj. F-46-R. job no. 2., 71 p.

1973. Artificial reservoir destratificution effects on phytoplankton: Water Pollution Control Federation Jour., v. 45. 110. $4.6 \mathrm{p}$.

Malueg. K. W., Tilstra. J. R., Schults, D. W., and Powers, C. F'. 1971. The effects of induced aeration upon stratification and eutrophication processes in an Oregon farm pond [abs.]: Internat. Symposium on Man-made lakes: Knoxville, Tenn., May 3-7, 1971.

Rainwater. F. H.. and Thatcher. L. L., 1960, Methols for collection and analysis of water samples: U.S. Geol. Survey Water-supply Paper 1454, $301 \mathrm{p}$.

Robinson, E. I.. Irwin. W. H., and Symons, J. M.. 1969, Influence of artificial destratification on plankton populations in impoundments: Kentucky Acad. Sci. Trans.. v. 30, nos. 1 and 2 , p. 1-18.

slack, K. V.. Averett, R. C., Greeson, F. E., and Lipscomb, R. G.. 1973, Methods for collection and analysis of aquatic biological and microbiological samples: U.S. Geol. Survey

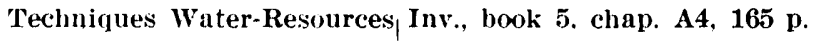

Weber, C. K., 1966, Methols of collection and analysis of plankton and periphyton samples in the water pollution surveillance system: Federal Water Pollution Control Adm. Water Pollution Surveillance System Applications and Devel. Rept. 19, 26 p. 



\title{
EXPLORATION FOR PORPHYRY COPPER DEPOSITS IN PAKISTAN USING DIGITAL PROCESSING OF LANDSAT-1 DATA
}

\author{
By ROBERT G. SCHMIDT, Reston, Va.
}

\begin{abstract}
Rock-type classification by digital-computer processing of Landsat-1 (formerly ERTS-1) multispectral scanner data has been used to select 23 prospecting targets in the Chagai District, Pakistan, 5 of which have proved to be large areas of hydrothermally altered porphyry containing pyrite. The known porphyry copper deposit at Saindak was used as a control area. Empirical maximum and minimum apparent reflectance limits were selected for each multispectral scanner band in each rock type classified, and a relatively unrefined classification table was prepared. Where the values for all four bands fitted within the limits designated for a particular class, a symbol for the presumed rock type was printed by the computer at the appropriate location; these symbols formed a classification map. Drainage channels, areas of mineralized quartz diorite, areas of pyrite-rich rock, and the approximate limit of propylitic alteration were very well delineated on the computer-generated map of the test area. The classification method was then used to evaluate $2,100 \mathrm{~km}^{2}$ in the Mashki Chah region, east of the test area, and a partial check of the results was made in the field. The results of the experiment show that outcrops of hydrothermally altered and mineralized rock can be identified from Landsat-1 data under favorable conditions. The empirical method of digital computer classification of the multispectral scanner data was relativels unrefined and rapid. The five mineralized prospecting sites identified are in locations that I would not have selected as favorable on the basis of geologic knowledge or photogeologic interpretation at the time of the investigation.
\end{abstract}

Mapping and mineral prospecting were undertaken at Saindak (fig. 1), in Pakistani Baluchistan, in 1962 because the locality was considered one of the more favorable areas in the Chagai District; the results of the study were reported by Ahmed, Khan, and Schmidt (1972). Detailed geologic and geophysical mapping and exploration at Saindak were later resumed by the Geological Survey of Pakistan (Khan, 1972; and Farah and Nazir Ullah, 1973), and the Resource Development Corporation of the Pakistan Government.

In 1962, after discovery of the disseminated copper sulfide ore body at Saindak, we noted that tonal changes and topographic expression related to hydrothermal alteration might be detected by optical remote sensing. When geological applications of data from the Earth Resources Technology Satellite, now Land- sat, were still in a planning stage, the area of the Saindak deposit was discussed by U.S. Geological Survey personnel as an ideal test site for a remote-sensing experiment (fig. 2).

Two investigations concerned with direct detection of sulfide mineralization and hydrothermal alteration using Landsat-1 multispectral scanner data have used the porphyry copper deposit at Saindak as a test site because the deposit is large, has well-developed alteration zones and little vegetation, is well mapped, well exposed, and undisturbed. In addition, I was familiar with the deposit and region.

In the first investigation (Schmidt, 1974), false-color composite images made from Landsat-1 data were used to select light-toned areas that might be related to hydrothermal alteration. This rapid inexpensive method was handicapped by the general resemblance

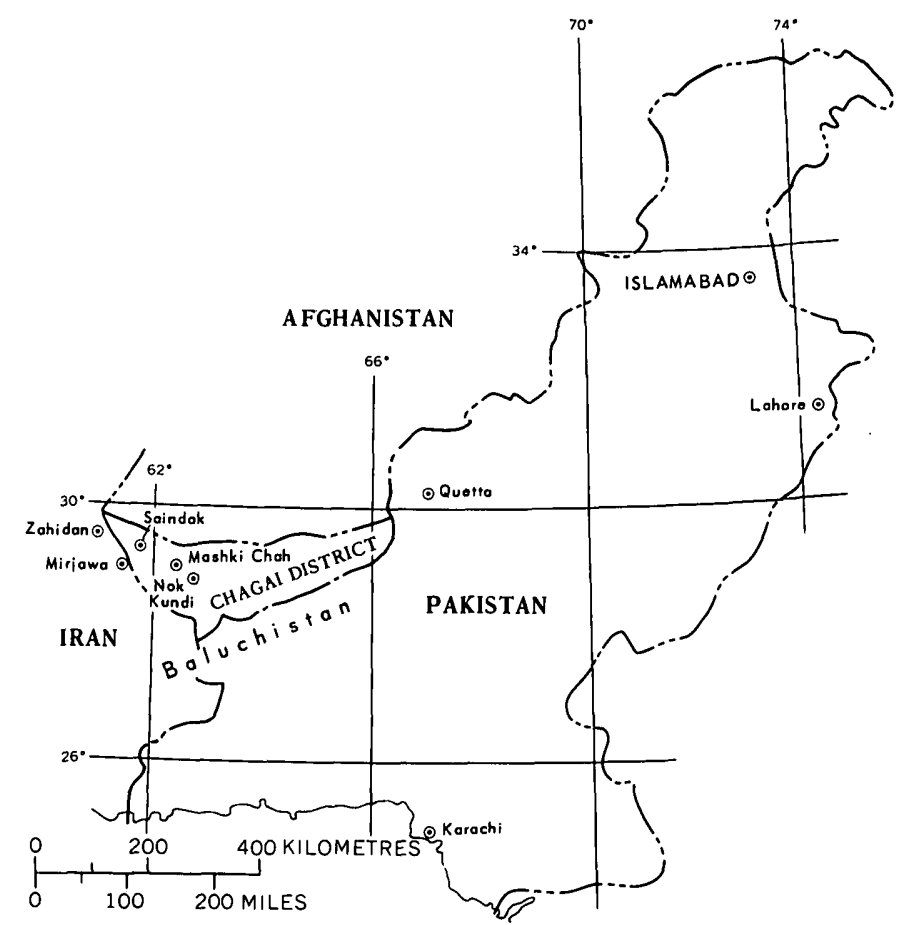

Figure 1.-The Chagai District and Saindak, Pakistan. 


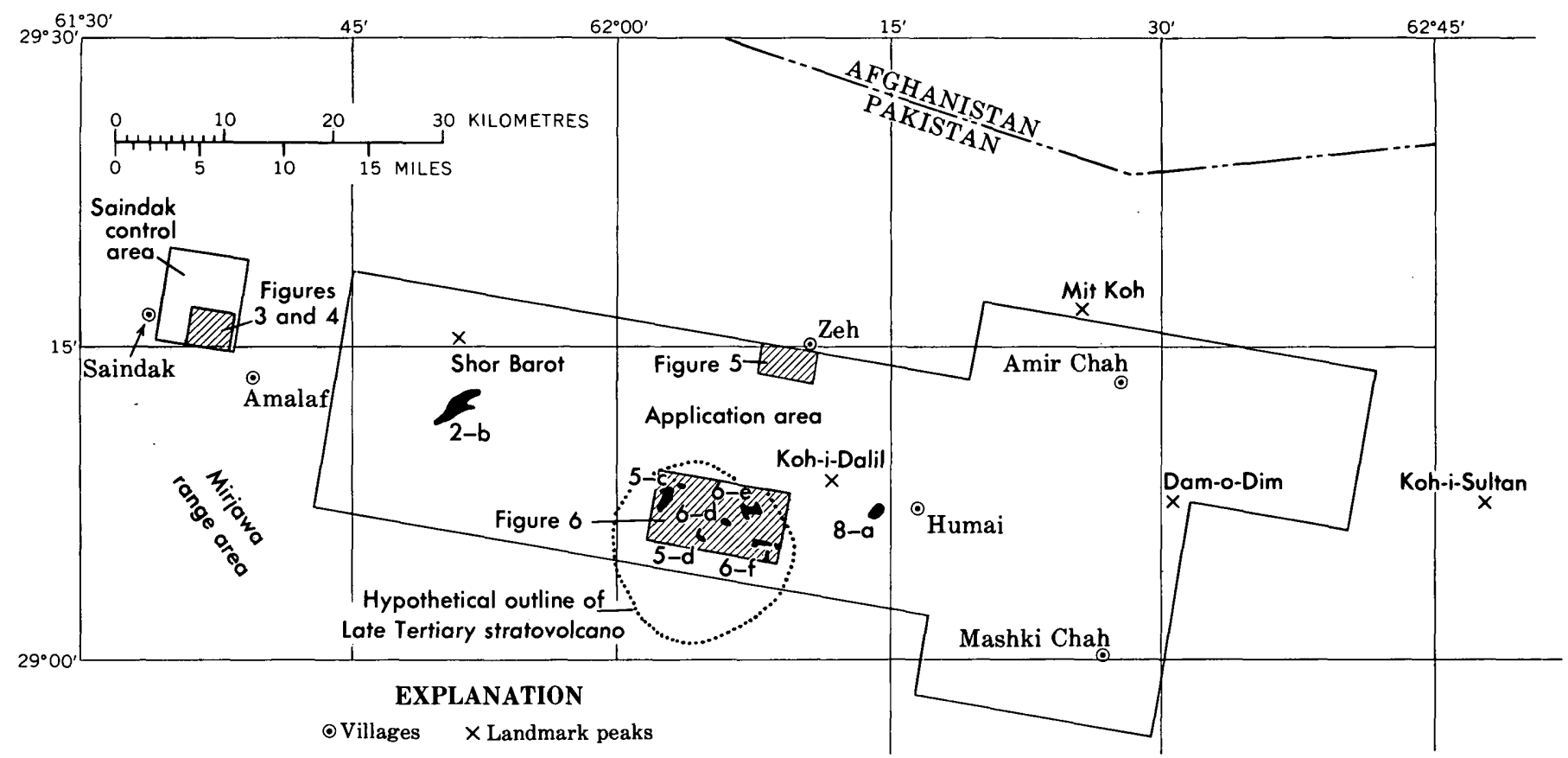

Figure 2.-The Saindak-Mashki Chah area of the western Chagai District showing the control area near Saindak and the area where the digital classification method was applied. The numbered locations near Koh-i-Dalil are mineralized prospect sites described in the text. Line pattern indicates areas detailed in other figures.

of hydrothermally altered areas to light-toned patches in dry washes and also to many areas mantled by eolian sand. Colors and densities for the four wave bands were selected to enhance the contrast between eolian sand and other light-toned features as much as possible. Many light-toned anomalies were eliminated as probable dry-wash material, and some others were rejected for other geologic reasons. The coincidence of anomalous light tones with areas shown as felsic intrusive rocks on published photogeologic maps (Hunting Survey Corp., Ltd., 1960) was considered favorable. Field checking showed that this initial assumption was probably false, as weathering and erosion of the hydrothermally altered porphyries of the region have resulted in topographic forms so low and rounded that they would probably not be classed as felsic intrusive rocks by photogeologic methods.

After the composite images were evaluated, even though several targets for field prospecting had been selected, it seemed desirable to seek a method that could discriminate more definitely between several surface materials that yielded similar tones.

In the second investigation, digital computer processing was used to classify data from the four multispectral scanner bands (MSS bands 4, 5, 6, and 7) and to attempt to identify the surficial material, particularly those types of material known to be related to hydrothermal alteration and mineralization, but also those light-toned surface types most likely to be confused with the hydrothermal alteration and mineralizationrelated surfaces.

In 1973, experimental work was undertaken by Ralph Bernstein and Bruce Clark of the Federal Systems Center, IBM Corp., on digital processing of Landsat-1 data as a method of locating mineral deposits. Clark extracted numeric data for the four MSS bands for each pixel from small test areas at Saindak chosen to represent single rock types and single rockalteration types. Two experimental classification tables were then prepared, both of which delineated the Saindak mineralized area remarkably well (fig. 3), and which suggested that the method might be refined and used as an exploration tool. Computer services were purchased from the IBM Corp. by the U.S. Geological Survey to refine the classification tables for the area of the known deposit at Saindak, and then to use the refined method for the mineral evaluation of the 2,100 $\mathrm{km}^{2}\left(810 \mathrm{mi}^{2}\right)$ of the Chagai District where the potential for finding porphyry copper deposits is good and where widely distributed eolian sand has made visual analysis of colored composites particularly troublesome (fig. 2). Mineral evaluation undertaken in this experiment resulted in the selection of 23 targets for field prospecting. After completion of the digital computer classification experiment, a field check was made, October 13-31, 1974, of some of the prospecting sites selected in the two studies. 

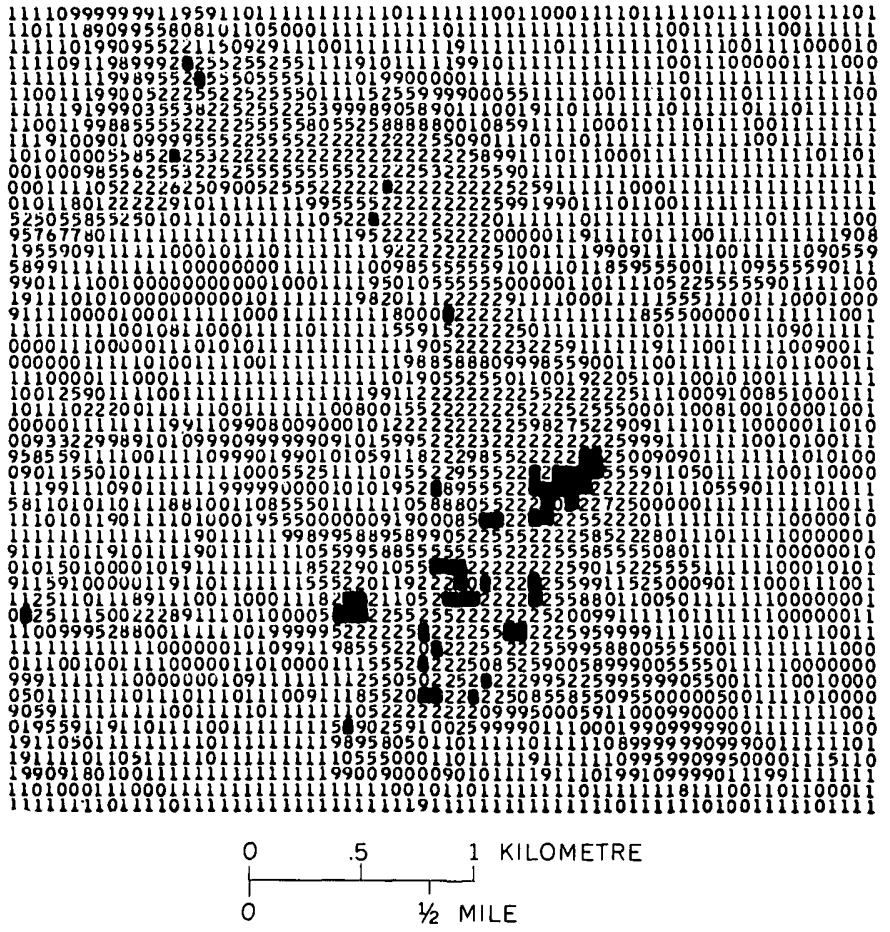

Frgure 3.-Part of a 9-class map of Saindak control area. Class 4 , one class used to identify mineralized quartz diorite, has been blackened to aid recognition and correlates clasely with outcrops of mineralized quartz diorite (the class numbers are not the same as those in table 1). Classes 5, 8, and 9 together delineate dry wash areas. Class 2 outlines the area of known pyritic rock fairly well, but also appears in dry wash areas too frequently. Other classes do not fit known geology.

Acknowledgments.-The original color composite experiment was partly supported by the National Aeronautics and Space Administration. Financial support for the digital processing experiment and for part of the travel expenses of the field checking was provided by the EROS Office. Logistical support in the field in Pakistan was furnished by the Resource Development Corp., and the enthusiastic help given by their personnel made it possible to finish much more fieldwork in a short time than I had expected. Special thanks are due Dr. S. Durrani of Resource Development Corp. who accompanied me throughout the field checking.

\section{REGIONAL GEOLOGY}

The Mirjawa ranges, which include the Saindak deposit, and the Mashki Chah region where the classification method was applied, have somewhat different regional geology. The rocks of both areas are Cretaceous to Quaternary in age. The Mirjawa range area has mostly northwest-trending folded and much faulted sedimentary and volcanic-sedimentary strata containing small amounts of intrusive and extrusive igneous rock. The detailed geology of the Saindak area (Ahmed and others, 1972) is fairly representative of the geology of this border region. Cretaceous sedimentary rocks represent a wide variety of marine and continental depositional environments; lower Tertiary rocks are mostly shallow marine, and upper TertiaryQuaternary strata are largely continental.

Saindak is a few kilometres east of the eastern edge of a wide area of regional metamorphism centered around a granitic intrusive body $40 \mathrm{~km} \mathrm{(25} \mathrm{mi)} \mathrm{west}$ of Saindak in Iran.

Rocks of the Mashki Chah region, a western extension of the Chagai Hills, are also folded and faulted, but the folding lacks the strong linear pattern characteristic of the Mirjawa ranges. Volcanic rocks with low dips, probably initial, are common and widespread. Intrusive rocks are more abundant; several volcanic necks are known, and volcanic cones and probably plug domes are present. Recently dried or still weakly flowing sinter-depositing saline springs, plus a few fumaroles on the volcano Koh-i-Sultan suggest that hydrothermal activity is continuing.

All the western part of Pakistan is covered by $1: 253,440$-scale photogeologic reconnaissance maps (Hunting Survey Corp., Ltd., 1960), but probably less than 1 percent of the Chagai District has been mapped in detail.

\section{ECONOMIC GEOLOGY}

Mineral reconnaissance in the Chagai District has been spotty and mostly in search of high-grade deposits; if a porphyry copper deposit had been noticed during early investigations, it might have been passed over as too low grade for consideration at that time. Several large areas of the Chagai District containing abundant intermediate and felsic volcanic rocks and small hypabyssal intrusive bodies of Cretaceous through Pleistocene age may be considered to have a good potential for large sulfide deposits of the porphyry copper type.

At Saindak, several small copper-bearing porphyritic quartz diorite stocks cut northward across the folded lower Tertiary stratigraphic section. The stocks may be cupolas on a single barely exposed granitic body $8 \mathrm{~km}(5 \mathrm{mi})$ long and as much as $1.5 \mathrm{~km}$ (1 mi) wide, or may be separate but related intrusive bodies. The group of stocks is surrounded by zones of contact metamorphism and hydrothermal alteration. The stocks are enclosed in a sulfide-rich envelope that contains as much as 15 percent pyrite by volume; the envelope in turn is surrounded by a zone of propylitic alteration in which pyroclastic rocks in particular are altered to a hard dark epidote-rich hornfels. The most highly 
altered central part of the deposit is not fully defined, but there is pervasive quartz-sericitic alteration, and recent studies by Shahid Noor Khan are outlining a potassic alteration zone containing much hydrothermal biotite. Fluid inclusions are abundant in quartz grains. Many of the fluid inclusions contain halite crystals, and some gas-rich inclusions suggest formation of the quartz under near-boiling conditions (J. T. Nash, written commun., 1973).

The well-developed pattern of hydrothermal alteration zones and the general characteristics of the copper sulfide mineralization are similar to the simple ideal model of porphyry deposits described by Lowell and Guilbert (1970), but only detailed geological mapping plus extensive exploration drilling, such as the program now being carried out by the Government of Pakistan, can determine whether the deposit is of economic significance.

Hematite and iron sulfide skarns are common replacements of limestone beds in the propylitic zone of the deposit. Quartz-diorite dikes are common and locally abundant within the alteration zones and are easily identified on aerial photographs. Veins containing sparse argentiferous galena and copper minerals are also common within the propylitic zone. The occurrence together of skarns, dike swarms, and base-metal veins in other locations in the region is considered a favorable factor in prospecting for porphyry copper deposits.

The sulfide-rich zone, including both the intrusive porphyry stocks and the adjacent pyrite-rich country rock, has been eroded to form a light-toned valley. Desert soils associated with many porphyry copper deposits the world over have distinct red and orange color anomalies; this is true at part of the Saindak deposit as well, where the mineral natrojarosite has been identified in the pigmented material. In the central valley at Saindak, however, windblown and alluvial grains considerably dilute or cover much of the colored soil.

In plan view, this valley is encircled by a symmetrical rim of hills more rugged and darker in tone than the surrounding region (Ahmed and others, 1972, fig. 2 ). These hills, generally corresponding to the erosionresistant zone of hornfels and propylitic alteration. form the outer boundary of the whole exploration target.

\section{CLASSIFICATION EXPERIMENTS}

Classification experiments were conducted in an area immediately surrounding the Saindak deposit. In Clark's experimentation, a shade print of MSS band 5 was prepared and used as a map to identify the loca- tion of individual data rectangles, or pixels, within areas of known rock type. Numeric data for the four MSS bands were extracted for each pixel in the known areas, the obviously unconforming pixels were rejected, and maximum and minimum apparent-reflectance limits were chosen for each rock type. The computer searched the data for the four bands for each pixel, and where the values fit the apparent-reflectance limits chosen for a class, the symbol for that class was printed at that location. When the observed values fit more than one class (where classes were set up with overlapping limiting values), a pixel was placed in the class that was considered earliest in the search sequence, resulting in some bias. Clark tested one table using nine classes (fig. 3) and one using five. Areas of mineralized quartz diorite were delineated very well, but the three classes of pyritic rock also included far too many pixels within light-toned dry-wash material. The drainage pattern was well defined.

In the EROS-funded experiment, three revisions were made and tested, and one alternate table was tried. In the early tables, there was no class for eolian sand because there were no areas of sand in the Saindak vicinity that we could use as control; the area where the method was to be applied, however, contained much sand and "discrimination between mineralized felsic rock:and eolian sand was expected to be a major problem. An area of known dune sand outside the known area was used to establish the sand classes.

The final classification table is shown as table 1 . We have dealt with only three general types of materials: (1) mineralized rock, including intensely hydrothermally altered (quartz-sericite zone) quartz diorite, and pyritic rock, (2) alluvial and eolian materials, recently moved dry-wash alluvium and eolian sand being the materials most likely to be confused with the first group, and (3) a loose category of dark surfaces that includes both hornfels-type bedrock and many areas of desert-varnished lag-gravels (especially in class 10). The computer-generated classification map of the Saindak deposit that was made using the final classification table is shown in figure 4 .

Four of the main surface types are each represented by two classes-a main, more restrictive class with reflectance limits in at least one band that make it exclusive from all other main classes, and a secondary class that overlaps the limits of at least one other class. Individual pixels classified in one of the main categories are intended to have a higher probability of correctly matching the surface material. Points classified in the secondary categories must be evaluated in the context of the classes of adjacent points. For example, if class 4 points (pyritic rock, secondary category) 


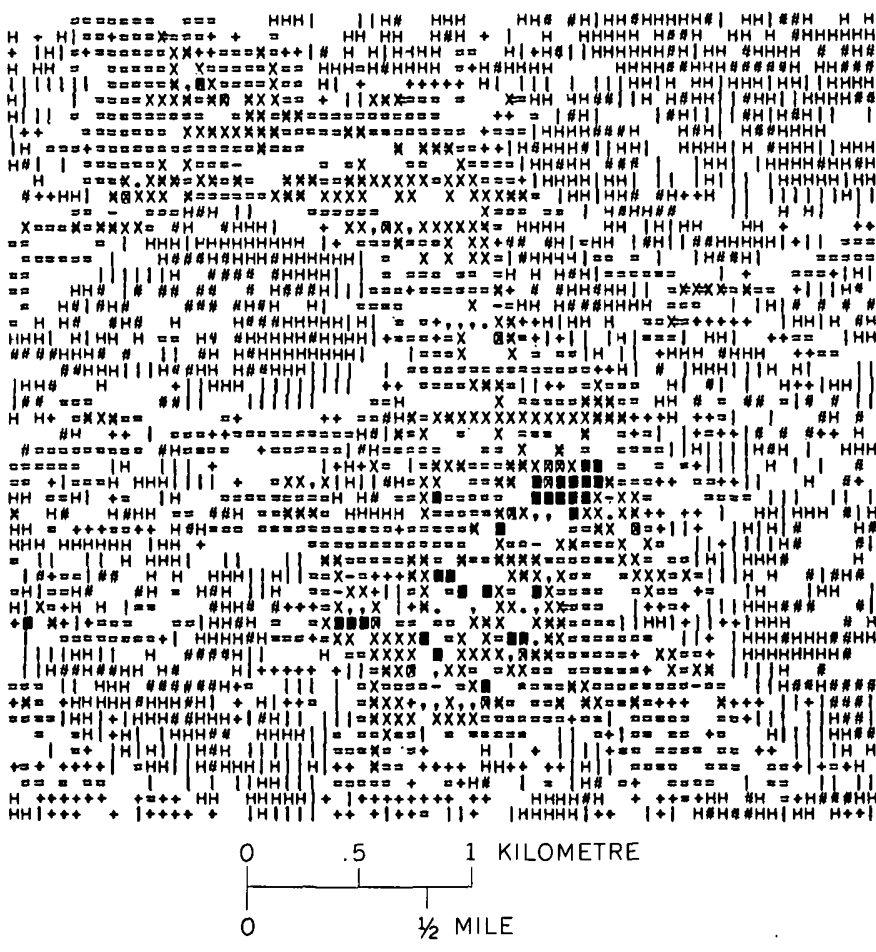

Figure 4.-Part of final classification map of test area.

TABLE 1.-Final table used in digital classification of MSS data in the Chagai District, Pakistan

\begin{tabular}{|c|c|c|c|c|c|c|}
\hline \multirow{2}{*}{ Rock type } & \multirow{2}{*}{$\begin{array}{l}\text { Class } \\
\text { No. }\end{array}$} & \multirow{2}{*}{ Symbol } & \multicolumn{4}{|c|}{ Band. } \\
\hline & & & 4 & 5 & 6 & 7 \\
\hline \multirow[t]{2}{*}{$\begin{array}{l}\text { Mineralized quartz } \\
\text { diorite. }\end{array}$} & 1 & - & $46-50$ & $52-60$ & $50-60$ & $18-22$ \\
\hline & 2 & $\nabla$ & $44-45$ & $52-60$ & $45-49$ & $18-19$ \\
\hline \multirow{2}{*}{ Pyritic rock } & 3 & * & $41-45$ & $47-54$ & $39-44$ & $16-17$ \\
\hline & $\begin{array}{l}4 \\
5\end{array}$ & $\begin{array}{l}x \\
=\end{array}$ & $\begin{array}{l}41-45 \\
39-46\end{array}$ & $\begin{array}{l}47-54 \\
39-46\end{array}$ & $\begin{array}{l}39-44 \\
35-44\end{array}$ & $\begin{array}{l}16-19 \\
14-17\end{array}$ \\
\hline Dry wash --- & & 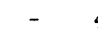 & $41-45$ & $46-51$ & $42-49$ & $18-19$ \\
\hline $\begin{array}{l}\text { Boulder fan - } \\
\text { Eolian sand - }\end{array}$ & $\begin{array}{l}-7 \\
-8 \\
-8\end{array}$ & & $\begin{array}{l}33-40 \\
38-44 \\
45-45\end{array}$ & $\begin{array}{l}39-46 \\
46-54 \\
46-127\end{array}$ & $\begin{array}{l}30-35 \\
42-51 \\
42-127\end{array}$ & $\begin{array}{r}9-16 \\
18-22 \\
18-63\end{array}$ \\
\hline \multirow{2}{*}{$\begin{array}{l}\text { Miscellaneous dark } \\
\text { surfaces. }\end{array}$} & 10 & 1 & $33-36$ & $28-38$ & 29-35 & $11-15$ \\
\hline & $\begin{array}{l}11 \\
12\end{array}$ & H & $\begin{array}{l}24-35 \\
29-36\end{array}$ & $\begin{array}{l}19-27 \\
28-38\end{array}$ & $\begin{array}{l}20-32 \\
20-28\end{array}$ & $\begin{array}{l}8-12 \\
9-14\end{array}$ \\
\hline
\end{tabular}

occur interspersed with class 3 points (pyritic rock, primary category), the secondary class points probably represent the same material; however, if class 4 points are interspersed with points of one of the sand classes, the level of confidence in the classification drops, and the whole assemblage is regarded as sand.

In building the tables, as the acceptable reflectance limits of a class are narrowed, fewer matches are found. In classes 1 and 2 , for example, if we choose limits that include most pixels in the training areas and also many pixels in all the areas of known mineralization, we also get false classifications in dry-wash material. The limits are subjectively adjusted wider or narrower so that enough points are classified correctly in the areas of known mineralization to call attention to those areas, and the false classifications are reduced to a minimum. The final tables used in this experiment have been revised a minimum number of times because revisions to the tables are costly and successive revisions generally achieve diminishing results. The use of few revisions, no ground checks during revisions, and the lack of incorporation of any ground-collected quantitative reflectance data into the experiment tend to place the whole study in the "quick and dirty" category.

\section{APPLICATION OF METHOD TO EVALUATION OF 2,100 SQUARE KILOMETRES}

The final classification table was used to evaluate an area in the Mashki Chah region adjacent to the Saindak test area, and considered to have good potential for porphyry copper deposits (fig. 2). The results were printed out in 13 computer-generated vertical strip maps. These maps were examined for groups of pixels classified as mineralized quartz diorite and pyritic rock, and about 50 groups or concentrations were identified. Each was then evaluated for probability of correct classification, relationship to concentrations of other classes, and comparison with known geologic data-both rock types and occurrences of hydrothermal mineralization. From this examination, localities most deserving reconnaissance checking in the field were chosen, and these prospecting targets were graded into priority categories. The grading process was of neces: sity very arbitrary. Thirty target areas were selected, four of first priority and the rest of lesser interest. The locations of these targets were transferred visually to an enlarged digitally enhanced image of MSS band 5 in order to simplify location in the field:

As part of the field check, all anomalous areas were first examined on stereoscopic pairs of $1: 40,000$-scale aerial photographs. At this point it was possible to reject seven areas as related to windblown sand (fig. 5 ), leaving 23 sites. Nineteen sites were examined in the field, and four desirable sites were bypassed in the field checks. Of the four "high-priority" prospecting sites, none were found to be significantly mineralized or hydrothermally altered, except for a little alteration in part of area $2-b$ (fig. 2 ). Of the five sites found to be outcrops of hydrothermally altered sulfide-rich rock, two had been rated as "medium priority" prospects, and three as "low priority." Two additional sites have altered rock containing some sulfide but seem less attractive for prospecting at this time.

Two areas recommended in the false-color composite study were also examined in the classification experiment, but neither was classed as mineralized by thu digital-processing method. 


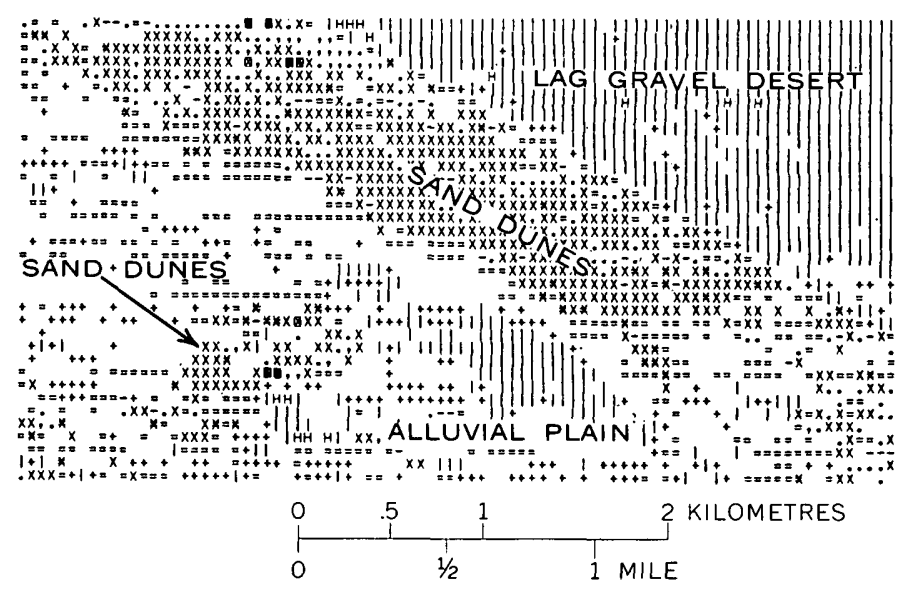

Figure 5.-Area of dunes near Zeh (see fig. 2) falsely classified as mineralized quartz diorite (classes 1 and 2) and prritic rock (classes 3 and 4 )

\section{THE NEWLY IDENTIFIED AREAS OF MINERALIZATION}

The areas of mineralization found in this investigation are in two general locations. At the first location, four of the mineralized sites ( $5-\mathrm{c}, 5-\mathrm{d}, 6-\mathrm{d}, 6-\mathrm{e})$ occur in what is probably the central core of the eroded remnant of a large stratovoloano (figs. 2 and 6). Of the four, site $5-\mathrm{c}$ seems to be a separate mineralized area, but sites 5-d, 6-d, and 6-e may be parts of a single large mineralized body as the areas between the sites are covered by Holocene alluvium. The second location (site $8-a$, fig. 2) is $15 \mathrm{~km}(9 \mathrm{mi}$ ) east of site $6-\mathrm{e}$ and well outside the core of the stratovolcano, although it may be within the flank of the old volcano edifice.

Site 5-c (estimated area mineralized, $2.3 \mathrm{~km}^{2}$ ).-The large area of site 5-c seems underlain by light-toned rock with silicic, argillic, and probably some sericitic alteration. Some of this rock is porphyry and probably tuff and sandstone or tuffaceous sandstone. Most sulfide was present formerly as veinlets forming stockworks, and disseminated sulfide was probably minor. No copper minerals were noted in the field.

Site 5-d (estimated area mineralized, $0.5 \mathrm{~km}^{2}$ ).-The northern part of site $5-d$ consists of scattered small exposures surrounded by dry-wash alluvium. The outcrops are quartz-sericite altered porphyry having resistant ribs of silicic rock and vein quartz. The rock contains limonite stains and sulfide casts, but not as abundantly as at sites $6-\mathrm{d}$ and 6 -e.

The southern part of site $5-\mathrm{d}$ consists of siliceous and argillic altered porphyry and tuffaceous rock. Pseudomorphs after sulfide are less abundant than in other sites described; some sulfide seems to have been disseminated and some was in veinlets. Where un-

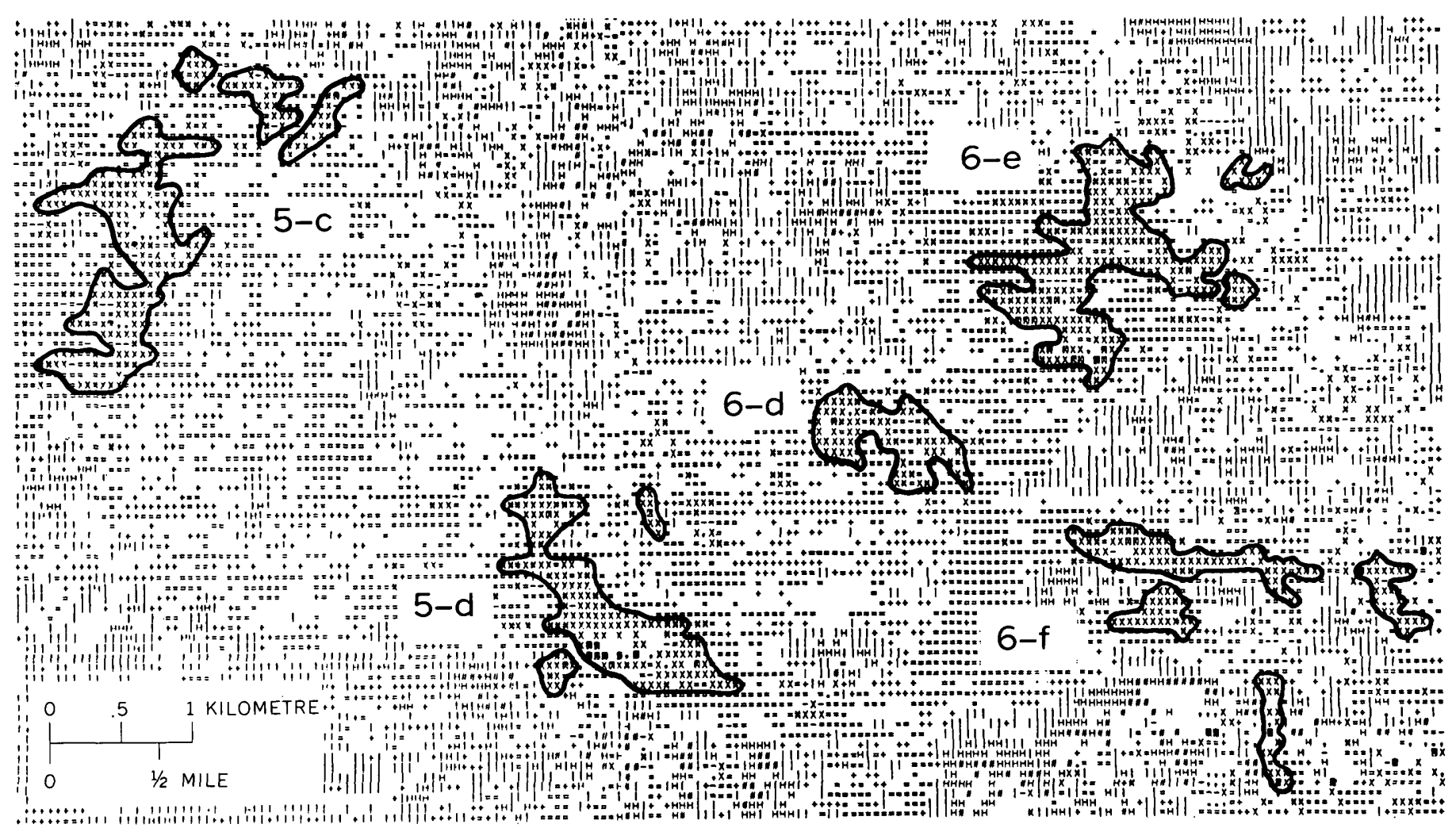

FIgURE 6.-Classification map of an area west of Koh-i-Dalil showing five areas classed as "mineralized." 
leached sulfide was seen, it appears to be only pyrite. Black tourmaline is common locally.

The outcrops in site 5-d tend to be mantled by hard siliceous material that may represent only narrow altered zones and may not be truly representative of the main mass of rock.

Site 6-d (estimated area mineralized, $0.8 \mathrm{~km}^{2}$ ).--The bedrock at site $6-d$ is all felsic porphyry having intense quartz-sericite and argillic alteration. The pyrite mineralization, part disseminated and part in veinlets, is pervasive and is estimated at 5-10 percent of the rock volume. The sulfide is now mostly leached, but residual masses of unleached rock are not as rare here as at the other sites. Several places have traces of oxidized copper minerals in rocks or soils; at one place, weathered pyrite has rather common copper carbonate stains, and the analysis was 0.3 percent copper. Jarositic and gypsum-rich soils are common. This is the most intensively altered area found in the field investigation.

Site 6-e (estimated area mineralized, $0.3 \mathrm{~km}^{2}$ ).- Site 6 -e is an area of highly altered quartz-rich porphyry. In the northwest end are many residual blocks containing 5-10 percent pyrite, but only minor traces of copper minerals. In a brief stop at the southeast end of the area, we saw what may be argillic alteration in rock from which all sulfides have been leached.

Site 8-a (estimated area mineralized, $0.8 \mathrm{~km}^{2}$ ).-Site $8-a$, an area of extensive sulfide mineralization associated with what is probably intrusive feldspar porphyry and well-formed propylitic and quartz-sericitic(?) alteration zones, has many of the characteristics of a porphyry copper deposit. The site forms a low topographic basin bounded by major dry washes on the east and west, by an andesite flow-capped mesa on the north, and a low range of dark andesitic(?) hills on the south. The area is partly rimmed on the east side by hills of propylitically altered gray feldspar quartz porphyry. Westward, this grades into a zone containing local pockets and lenses of argillic alteration, then into the most highly altered central core. Hydrothermal alteration of the central part of the deposit is intense, resulting in a very quartz-rich rock containing abundant (5-10 volume percent) pyrite and perhaps other sulfides. Most of the sulfides have been completely leached out, leaving voids and limonite-filled cavities; only a few cores of unleached rock remain. .Jarositic soils and gypsum are common throughout the valley. We saw only a few traces of copper minerals.

The intrusive porphyry is enclosed in shale and fine sandstone; in the northerm part of the valley, the intense alteration extends to the edge of the porphyry and beyond to include a sizable area of sandstone as well. Abundance of limonite suggests that the altered sandstone was as pyritic as the altered porphyry.

A massive rock near the center of the valley is perhaps a fine uniform-textured phase of the porphyry, a separate intrusive body, or a well-indurated tuff. It is thoroughly altered (the alteration tentatively classified as argillic) and locally contains traces of copper.

A white porphyry found at several places in the mineralized zone may be an altered form of the main porphyry or perhaps a separate intrusive body which may have been the activating agent in the mineralization.

Leaching of the outcrops at all of the sites has been intense; if any copper was formerly present, the possibility of a secondary enriched zone seems very good. The leaching is so intense that the lack of visible copper minerals is not too negative a factor. The lack of sparsely mineralized quartz veins in the propylitic zone at site $8-a$ is not consistent with many other porphyries, however.

Two of the sites examined have lesser amounts of hydrothermal alteration and sulfide. The east end of area 2-b (fig. 2) is underlain by a very light-toned quartz feldspar porphyry. I believe that some quartz and argillic alteration has taken place, but the rock may be originally silicic and relatively fresh. Iron oxide staining is abundant in a few restricted places. Neither sulfides nor copper carbonate stains were noted in the field. The middle and western parts of area $2-b$ are propylitically altered sedimentary and volcanic rocks that have probably very little economic mineral potential. Site 6-f (figs. 2 and 6), has been examined only near the east end where some hydrothermal rock alteration and probably pyrite mineralization is present, but most of the tonal anomaly is due to dune sand. The western part of the site has not been inspected.

The mineralized areas, 5-c, 5-d, 6-d, 6-e., and 8-a, which I believe to be of the porphyry type, may be important deposits. If the sulfide near the surface contains no copper, we are possibly seeing only the top of a porphyry and the copper zone may be deeper. If even a little copper has been present in the now leached sulfide, the chance for a supergene ore body is excellent.

\section{SUMMARY}

A method of simple digital classification that uses areas of known hydrothermal alteration and mineralized and altered intrusive stock as control areas has been developed. The classification table was then used to evaluate $2,100 \mathrm{~km}^{2}$ of area regarded as having a high potential for deposits of the porphyry sopper type. Office evaluation of the resulting survey yielded 23 prospecting targets, 4 of which were considered high- 
priority. Field checks of 19 sites revealed that five sites were sizable areas of hydrothermally altered rock containing abundant sulfide, which is disseminated or in stockwork veins. Although the classification method used was relatively simple and unrefined, the number of sulfide-bearing areas identified was outstanding, and the falsely classified areas were not so many as to require an unreasonable amount of field checking.

The sulfide-bearing rocks are mostly porphyritic, and although copper minerals have been seen in only a few places, all the pyritic rocks are potentially the pyrite zones of porphyry-copper-type deposits. Thorough leaching of the surface rocks has removed whatever copper may have been present. Secondary copper enriched zones may exist at depth.

\section{REFERENCES CITED}

Ahmed, Waheeduddin, Khan, S. N. and Schmidt, R. G., 1972, Geology and copper mineralization of the Saindak quad- rangle, Chagai District, West Pakistan: U.S. Geol. Survey Prof. Paper 716-A, $21 \mathrm{p}$.

Farah, Abul, and Nazir Ullah, $R, 1973$, A note on magnetic measurements in copper-sulfide prospect area of Saindak, Chagai District, Baluchistan, Pakistan: Pakistan Geol. Survey Inf. Release 63, 9 p.

Hunting Survey Corporation, Itd., 1960, Reconnaissance geology of part of West Pakistan ; a Colombo Plan Cooperative Project: Toronto, 550 p. (Report published by Government of Canada for the Government of Pakistan).

Khan, S. N., 1972. Interim report on copper deposit of Saindak, Chagai District (Baluchistan), Pakistan: Pakistan Geol. Survey, Saindak copper report no. 1.

Jowell, J. D., and Guilbert, .J. M., 1970, Lateral and vertical alteration-mineralization zoning in porphyry ore deposits : Econ. Geology, v. 65, no. 4, p. 373-408.

Sclımidt, R. G., 1974, The use of ERTS-1 images in the search for large sulfide deposits in the Chagai District, Pakistan : U.S. Dept. Commerce Natl. Tech. Inf. Service, E74-10726, $38 \mathrm{p}$. 


\title{
A PORTABLE HELIUM SNIFFER
}

\author{
By IRVING FRIEDMAN and E. H. DENTON, Denver, Colo.
}

\begin{abstract}
A portable helium sniffer has been developed for fleld use. The instrument is mounted in a four-wheel-drive pickup truck and can detect 50 parts per billion of helium in soil gas. The usefulness of helium sniffing in soil is being investigated as a prospecting tool in gas, oil, uranium, and geothermal prospecting as well as in earthquake prediction.
\end{abstract}

The abundance of helium in soil gas has been used as a prospecting tool for gas and oil as well as for uranium and geothermal resources. In all previous applications, the relative helium abundance in soil gas has been determined in the laboratory. The recent increase in interest in techniques for prospecting for energy resources prompted us to attempt the adaptation of a commercial helium leak detector to field use as an onsite, instantaneous helium analyzer. Fortunately, onthe-shelf instruments needed only slight modifications. After a few months of development a truck-mounted unit was assembled that was able to traverse rough terrain with no operational problems and still maintain a capability of measuring 50 parts per billion helium ( $\approx 1$ percent of the normal helium abundance in air) in gas pumped from the soil through a small hollow probe pushed or pounded about $60 \mathrm{~cm}(2 \mathrm{ft})$ into the soil.

The basic instrument was a model 24-120B helium leak detector manufactured by the Instrument Products Division of E. I. DuPont and Co. This instrument consists of a 1 -cm-radius $180^{\circ}$-deflection mass spectrometer pumped by an oil diffusion and mechanical pump through a liquid nitrogen-cooled trap. The instrument maintains a constant ionization current as well as stabilized accelerating and focusing voltages.

The collected ion beam of $\frac{\mathrm{M} \text { (mass) }}{\mathrm{e} \text { (charge) }}=4$ is amplified

by an electrometer d-c amplifier and appears as a meter readout. The gas to be analyzed is admitted to the mass spectrometer through a variable leak valve. The source pressure is normally adjusted to be below $2 \times 10^{-4}$ torr $(1$ torr $=133.3$ pascals $)$.
To increase sensitivity, we increased the source pressure somewhat to $5 \times 10^{-4}$ torr and also increased the electron-ionizing current by a factor of 1.5 by increasing filament temperature. Although these changes decrease filament life, we find that the filaments last for more than $50 \mathrm{~h}$, even with the rough handling that the instrument receives. Inasmuch as changing a filament in the field requires only $10-15 \mathrm{~min}$, we believe that the increased sensitivity is worth the shorter filament life.

Zero drift and sensitivity changes in the amplifier are compensated for by comparing the helium response in the sample gas with that in two standard gases, one containing about $5 \mathrm{ppm}$ helium and the other about $10 \mathrm{ppm}$. These reference gases have been analyzed by the U.S. Bureau of Mines Laboratory in Amarillo, Tex., and are in steel cylinders containing enough gas to last for many thousands of determinations. In normal operation we measure the helium abundance of the two reference gases for approximately $1 \mathrm{~min}$ each and then measure our sample (unknown) gas for about 1-2 min. The amplified mass-4 beam is displayed on a strip-chart recorder. Gas switching is usually carried out using solenoid-operated valves and can be operated automatically if desired.

The sample probes that we originally used were made of $1 / 2$-in. water pipe with a $60^{\circ}$ cone point and were driven into the ground with the help of a manual piledriver. Later William Long designed smaller diameter probes that we were able to either push or drive into the ground with the help of a 3 -lb weight that slips over the upper part of the probe. Small holes in the side of the probe near the bottom admit the soil gas into the hollow probe. The gas is then pumped through Tygon tubing past the mass-spectrometer variable leak valve, where some of the gas is admitted to the spectrometer. An alternate method of sample introduction is by the use of a hypodermic syringe to transfer gas from the probe to the mass-spectrometer inlet system. A simple constant-pressure inlet system for use with the hypodermic-syringe sample transfer was devised by Denton. The variable leak valve supplied with the instrument proved to be too difficult to 
adjust and has been supplemented by another variable leak valve (model 203, Granville Phillips Co.) that allows precise adjustment of source pressure.

Inasmuch as the amplifiers used in the mass spectrometer to regulate ionization current were magnetic amplifiers, we found that the power supplied to the electronics must not only be voltage regulated but also be a good sine wave and of constant frequency. Experimentation disclosed that power from a gasoline-driven generator could be used to drive an electric power supply consisting of a stabilized 60-cycle quartz oscillator and solid-state amplifier providing power well stabilized in voltage, frequency, and wave form (model 251, Elgar Corp. power source with model 461-.01 plug-in quartz oscillator).

The first model of the helium sniffer was mounted in a four-wheel-drive panel truck. The generator was towed in a small trailer. All units can be operated while the vehicle is in motion, even over rough ground. The spectrometer, electronic voltage regulator, and recorder were mounted on a board placed on the vehicle rear seat. The board in turn was connected to the vehicle floor through a small automobile hydraulic shock absorber. The first model performed well, except for the difficulty of maneuvering a trailer when backing out of rough country.

The second model has been mounted in the rear section of the four-door "crew" cab of a four-wheel-drive pickup truck. Air-conditioning of the cab helps minimize problems with dust, and mounting the generator in the open bed of the truck effectively isolates it from the instrument and eliminates problems with carbon monoxide. The gas cylinders containing our standards and fuel for the generator are also kept in the rear bed, which is protected by a canopy or cover.

Data obtained with the helium sniffer in an area adjacent to hot springs have been published (Roberts and others, 1975). Further tests of the usefulness of helium sniffing in geothermal and uranium and gas and oil prospecting are in progress. The possibility of monitoring helium in seawater by the use of a gill or membrane permeable to helium is also under consideration. The possibility of heightened helium emission from ground water or from fissures adjacent to active faults prior, to an earthquake also bears investigation. It may be possible to place a helium sniffer astride an active fault and to monitor continuously and serially several probes sunk into ground. Presumably, the helium flux will increase before an earthquake in a manner similar to the observed increase in radon. However, since helium moves more rapidly than radon, owing to its much lower molecular weight, and since helium may. also be transported and released from warm ground water more efficiently than radon, owing to its unusual property of being more soluble in warm water than in cold, helium may give a quicker signal of an imminent, earthquake than radon.

Development of the helium sniffer is continuing. The use of a helium-permeable membrane to separate helium from soil gas is under investigation.

Acknowledgments.-We thank Terry Donovan, who encouraged and supported the development of the sniffer; William Long, who helped in all stages of development and made major contributions to probe development; Joe Jurceka for his help with instrument modification; and Alan Roberts and Mary Dalziel for much of the field testing.

\section{REFERENCE CITED}

Roberts, A. A., Friedman, Irving, Donovan, T. J., and Denton, E. H., 1975, Preliminary investigation of a helium survey technique for geothermal investigation: Geophys. Research Letters, v. 2, no. 6, p. 209-210. 


\title{
METHOD AND IMPORTANCE OF OBTAINING HUMIC AND FULVIC ACIDS OF HIGH PURITY
}

\author{
By R. L. MALCOLM, Denver, Colo.
}

\begin{abstract}
A detailed procedure incorporating centrifugation, pressure filtration, dialysis, resin exchange, and freeze drying is given for the extraction and purification of fulvic and humic acids from soils and sediments. By use of the procedure humic acids have been prepared which have less than 0.22 percent ash. The isolation of relatively ash-free natural organic matter preparations is an essential prerequisite to the characterization of organic reactivity in natural systems. Inorganic impurities of amorphous and crystalline clay minerals and various inorganic metal ions often lead to numerous complications and errors during experimentation with organic matter because the inorganic substances associated with the organic phase cause variable reactivity of the organic substances.
\end{abstract}

Inorganic contaminants in humic and fulvic acid extracts of soils and sediments have plagued organic geochemists and soil chemists for years. These contaminants are intimately associated with the organic phase and may exhibit properties similar to the organic phase with regard to cation exchange, anion exchange, complexation, water-holding capacity, heat capacity, and others. The presence of these contaminants is probably the major limitation on use of humic and fulvic acids ${ }^{1}$ for the study and interpretation of natural geochemical processes involving natural organic substances.

Ash content is the best measure of the quantity of inorganic contamination. Ash contents as high as 10 to 30 percent were commonly reported in the literature previous to 1950 and are sometimes this high in present-day reports. The majority of the humic and fulvic acid separates on which recent investigations have been performed have ash contents greater than 5 percent. Because it is difficult to obtain fulvic and humic acids with ash contents less than 5 percent by conventional techniques of purification, many of the organic matter investigations are in question because materials containing such high-ash contents are used.

${ }^{2}$ Humic acid is that complex mixture of natural organic compounds which are soluble in basic solvents and insoluble in $\mathrm{pH} 1$ acid solution. Fulvic acid is that complex mixture of natural organic compounds
which are soluble in basic solvents and remain soluble in $\mathrm{pH} 1$ acid solution.
There is no established method or fixed procedure for the extraction and purification of humic and fulvic acids from soils and sediments. Various investigators use one or more purification techniques such as centrifugation, dialysis, and resin exchange. The use of all these techniques with the inclusion of pressure filtration has made it possible to obtain fulvic and humic acids with less than 1.5 percent ash. The purposes of this paper are to present a detailed procedure for obtaining relatively ash-free natural organic substances and to emphasize the importance of using relatively ash-free preparations in investigations of organic matter.

\section{IMPORTANCE OF ASH-FREE ORGANIC MATTER PREPARATIONS}

The objective in extraction of organic matter from soils and sediments is to separate it from the inorganic phases such that the properties of the organic matter can be determined without interference from inorganic constituents. Therefore, the usefulness of the organicmatter extract is usually proportional to its purity. The major inorganic impurities are crystalline clay minerals; amorphous clay minerals of silica, aluminum, and iron; and various inorganic metal ions.

The inorganic impurities can lead to numerous complications and errors in analyses of organic matter and may even preclude certain analyses. For example, the intense infrared absorption of clays occurs in the $3,200-3,500 \mathrm{~cm}^{-1}$ wave-number region (bonded and free hydroxyl), in the $980-1,100 \mathrm{~cm}^{-1}$ region Si-O stretching), and in the $880-920 \mathrm{~cm}^{-1}$ region. Other functional groups of natural organic compounds also absorb at these wave numbers; therefore their infrared spectra are difficult to interpret. Also, because many of the clay-mineral impurities are crystalline, X-ray diffraction studies of natural organics are greatly hindered if not precluded.

Organic matter in soils is usually acidic with carboxyl $(\mathrm{COOH})$ and phenolic $(\mathrm{OH}$ attached to an aro- 
matic nucleus) groups accounting for many of the properties of the material. Several of the difficulties encountered and the apparently inconsistent results obtained in organic-matter-characterization studies are the result of heterogeneous ionic saturation of these functional groups and the blocking of a variable portion of these groups by inorganic impurities. The situation is partially analogous to describing the properties of a known organic acid and its metal salts. The properties of the free acid are grossly different from that of an acid salt and vary with the type of metal. salt and degree of salt formation. Thus, fulvic and humic acid functions should be expected to have a spectrum of properties depending upon the type and amount of inorganic impurities. The hydrogen-saturated (free acid form) ash-free preparation is an excellent standard for natural organic matter.

Additional errors due to inorganic impurities can arise in exchange studies. The ${ }^{-C E C ~(c a t i o n ~ e x c h a n g e ~}$ capacity) of organic matter is commonly determined by titration of the hydrogen-saturated form with base. The complete exchange capacity cannot be determined unless the organic matter is completely hydrogen saturated and low in ash content (Martin and Reeve, 1958). Clay and certain metal ions can either block exchange sites or be associated with the organic matter in such a manner that the full cation-exchange capacity cannot be determined. Certain metal ions associated with the organic matter, such as iron and aluminum, may also hydrolyze during titration, thus resulting in excessive base consumption. There is also the possibility that some of the exchange capacity is due to impurities present rather than to organic matter. This is analogous to sesquioxide coatings on clay being more relevant to $\mathrm{Co}^{2+}$ sorption than the clay mineral itself. The greater possibility is that the inorganic impurity will result in an apparently lower organic matter exchange capacity than the real value, because per unit weight, it has a much lower CEC than organic matter $(5-100 \mathrm{meq} / 100 \mathrm{~g}$ for clays versus $300-1,000 \mathrm{meq} / 100 \mathrm{~g}$ for natural organic matter).

Inorganic impurities may also cause errors in elemental analyses. Losses of bound hydroxyl water from sesquioxides, and clay minerals during pyrolysis at $1,000^{\circ} \mathrm{C}$ will result in large positive errors in organically bound oxygen and hydrogen. For example, Mattole River sediment fulvic acid, which has a high-ash content, results in a high elemental $\mathrm{C}$ and $\mathrm{H}$ and an ash-free organic total of 111.95 percent. On the other hand, for the relatively ash-free humic and fulvic acid preparations in table 1 , the summation of $\mathrm{C}, \mathrm{H}$, $\mathrm{O}, \mathrm{N}, \mathrm{S}$, and $\mathrm{P}$ elemental percentages account for 99 to 100 percent on an ash-free basis.

\section{DETAILED PROCEDURE FOR OBTAINING HUMIC AND FULVIC ACIDS RELATIVELY FREE OF INORGANIC CONTAMINATION}

1. Weigh accurately a representative 1 - to 10 -g portion of the bulk soil or sediment sample into a previously weighed drying vessel. Determine the percentage moisture of the sample on an oven-dry basis $\left(105^{\circ} \mathrm{C}\right)$.

2. Weigh a representative $300-\mathrm{g}$ portion (oven-dry basis) and place it into a 4 -litre plastic extraction vessel. The sample should not be dried at $105^{\circ} \mathrm{C}$, but the sample weight should be corrected to an oven-dry basis. Add 3 litres of $0.1 \mathrm{~N} \mathrm{NaOH}$ solution, purge the void space of the extraction vessel with $\mathrm{N}_{2}$ gas, affix a leakproof cap, and extract for $12 \mathrm{~h}$ on an oscillating shaker. Smaller or larger samples may be extracted according to the amount of organic matter desired, but a soil-solution ratio of approximately $1: 10(\mathrm{w} / \mathrm{v})$ should be maintained.

3. Remove the extraction vessel from the shaker and transfer the suspension into $250-\mathrm{ml}$ highspeed centrifuge tubes. Centrifugation of the extract for approximately $45 \mathrm{~min}$ at $10,400 G$ will remove the major part of the inorganic sediment from the extract.

4. The centrifuged extract is then transferred to a pressure-filter assembly (for example, Skougstad and Scarbro, 1968) fitted with a 4-in (100-mm)-diameter 0.45 - $\mu \mathrm{m}$ membrane filter. Previous to filtration of the organic extract the membrane filter should be slowly leached with 2 to 4 litres of demineralized water to remove any detergent from the filter membrane. Apply $\mathrm{N}_{2}$ gas pressure slowly until $40 \mathrm{lbf} / \mathrm{in}^{2}$ (275.8 $\mathrm{kPa})$ is attained. The small amount of clay and particulate organic matter present in the centrifugate will slowly clog the filter until the flow rate becomes less than $1 \mathrm{ml} / \mathrm{min}$. Refilter the portion which passed thru the filter before the flow rate is reduced to $1 \mathrm{ml} / \mathrm{min}$. Because the pressure-filtration process is slow, several 1- to 2-litre filter assemblies can conveniently be used. The filtrate is continually maintained at a $\mathrm{pH}$ of 2.5 to 5.0 immediately after filtration by addition of $5 \mathrm{~N} \mathrm{HCl}$. Acidification prevents organic oxidation by $\mathrm{O}_{2}$ uptake under alkaline conditions.

5. After filtration, combine the residue from the filter membrane and the centrifuge tubes and repeat the extraction procedure using a residue solution ratio of $1: 5(\mathrm{w} / \mathrm{v})$. 
6. Combine the two pressure-filtered extracts and raise the $\mathrm{pH}$ to between 9 and 10 with dropwise addition of $5 \mathrm{~N} \mathrm{NaOH}$ during vigorous mixing. Record the volume of the filtered extract. Collect triplicate $5.0-\mathrm{ml}$ aliquots of the filtered extract for carbon and nitrogen analyses. The amount of the organic matter extracted from the original sample can be calculated assuming the nitrogen and carbon contents of the extracted and unextracted portions are relatively the same.

7. Lower the $\mathrm{pH}$ of the filtered extract to 1.0 with dropwise addition of $5 \mathrm{~N} \mathrm{HCl}$ during vigorous mixing. Centrifuge the suspension at a speed necessary to free the supernatant fulvic acid of any precipitated humic acid. Decant the fulvic acid solution. Redissolve the precipitate in a small amount of $0.1 \mathrm{~N} \mathrm{NaOH}$, then reprecipitate the humic acid with $\mathrm{HCl}$. Repeat the centrifugation and decant the fulvic acid solution.

8. Combine fulvic acid decantates, let stand for 8 to $12 \mathrm{~h}$, then remove the remaining finely precipitated humic acids by pressure filtration through a 0.45 - $\mu \mathrm{m}$-membrane filter.

9. Cut several $700-\mathrm{mm}$ links of $80-\mathrm{mm}$-diameter cellulose acetate dialysis tubing, soak in distilled water for a few hours, pour approximately 1 litre of the fulvic acid decantate into each link, and tie both ends of the link securely excluding all air. Place the links in a horizontal position within a plastic dialysis tank. This will give a maximum ratio of solution to dialyzing surface and minimize leakage or tears at the ends of the dialysis bags. Dialyze against running distilled water for about $36 \mathrm{~h}$ or as much time as necessary to reduce the conductance of the fulvic acid solution to less than $10 \mu \mathrm{mho} / \mathrm{cm}$. During dialysis the $\mathrm{pH}$ of the fulvic acid preparation will rise to approximately $\mathrm{pH} 4$ and some precipitation may occur. Any precipitation is resolubilized according to step 14 of this procedure.

10. Prepare hydroxide-saturated (OH-saturated) exchange resin by filling a large-diameter preparatory column one-half full of water; then add several hundred grams of amberlite IRA400 anion-exchange resin. Saturate the resin with $\mathrm{OH}^{-}$- by leaching with 10 column volumes of 10 percent $\mathrm{NaOH}$ at a flow rate of 5 to 10 $\mathrm{ml} / \mathrm{min}$. After saturation, wash the column with deionized water until the conductivity of the column effluent is the same as the deionized water. Transfer a portion of the anion-exchange resin from the preparative column to a small column of approximately $20 \mathrm{~mm}$ in diameter by $400 \mathrm{~mm}$ in length.

11. Dissolve the precipitated humic acids in a minimum volume of $0.1 \mathrm{~N} \mathrm{NaOH}$ and dilute with deionized water to 5 to $10 \mathrm{mg} / \mathrm{ml}$. $\mathrm{OH}$ saturation of the humic acid is accomplished by passing the solution once through the exchange column of OH-saturated amberlite IRA-400 at a flow rate of $10 \mathrm{ml} / \mathrm{min}$ (Hori and Okuda, 1961). Proportionally smaller amounts of resin should be used for humic acids extracted from less than $300 \mathrm{~g}$ of soil or sediment.

12. Hydrogen-saturated (H-saturated) amberlite IR120 cation-exchange resin is prepared in the same manner as the anion-exchange resin except that 10 percent $\mathrm{HCl}$ is used for $\mathrm{H}$-saturation.

13. Place the $\mathrm{OH}$-saturated humic acid into a bottle containing 100 to $200 \mathrm{~g}$ of $\mathrm{H}$-saturated IR-120 exchange resin. Shake the humic acid-resin mixture on a reciprocating shaker for 15 to $20 \mathrm{~min}$. Pass the humic acid through an exchange column of freshly $\mathrm{H}$-saturated resin at a flow rate of 5 to $10 \mathrm{ml} / \mathrm{min}$. A resin column $20 \mathrm{~mm}$ in diameter by $600 \mathrm{~mm}$ in length is adequate for completion of $\mathrm{H}$-saturation.

14. Combine the dialyzed fulvic acid fractions in a large beaker(s) and solubilize any precipitate by addition of $1 N \mathrm{NaOH}$ until a pH of 9.5 is attained. In like manner, OH-saturate and H-saturate the fulvic acid by the same technique as employed for humic acids. Because most soils and sediments contain less fulvic than humic acid, a smaller amount of anionexchange resin should be used for $\mathrm{OH}$-saturation.

15. Immediately after H-saturation, the humic and fulvic acids should be freeze-dried (Malcolm 1968). The freeze-dried material should be stored in a desiccator for future use.

\section{RESULTS AND DISCUSSION}

The elemental composition and ash contents of some representative humic and fulvic acids extracted by this procedure are given in table 1. Ash contents for humic acids are generally less than 1 percent, whereas those for fulvic acids are less than 2 percent. The ash content of the fulvic acid from the Mattole River sediment is very high (15 percent) and could not be reduced by additional filtration or resin exchange. The elemental values are reported on an ash-free basis, which is computed from the experimentally determined elemental values and the ash content. For example, the experimentally determined carbon percentage for 
TABIE 1.-Ash-free elemental analyses, in percent, of organic matter extracts

[Analyses by Huffman Laboratories, Wheatridge, Colo.]

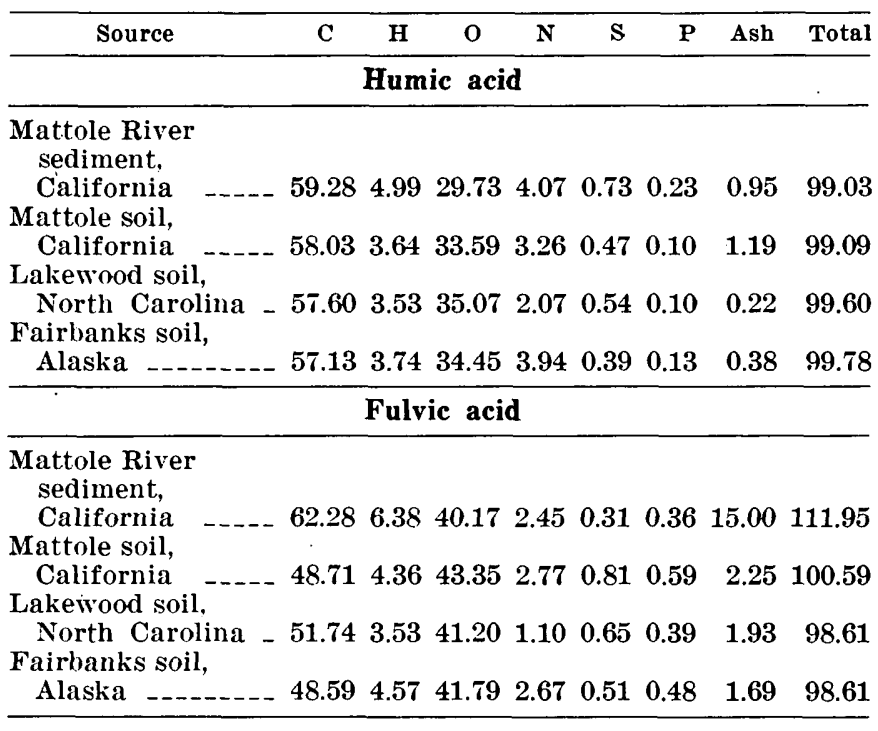

humic acid from the Mattole River sediment was 58.72 percent with an ash content of 0.95 percent. The corrected ash-free carbon value is 59.28 percent as shown in table 1.

Because pressure filtration of the centrifugate is a slow process, as mentioned in the procedure, it is desirable to use 10 to 15 filter units simultaneously. Partial clogging of the membrane filters is rapid and is desirable because it results in a more complete removal of clay minerals. Frequent changing of the partly clogged membrane filters is not recommended because the flow rate will virtually remain at a low, but adequate constant rate for long periods.

After the second precipitation and centrifugation the humic acids may be directly $\mathrm{H}$-saturated by resin cation exchangers or $\mathrm{H}$-saturated subsequent to $\mathrm{OH}$ saturation with resin anion exchangers. Humic and fulvic acids contain sites of both positive and negative charge, but the predominant charge is a $\mathrm{pH}$-dependent negative charge increasing with increasing $\mathrm{pH}$ to a maximum between $\mathrm{pH} 8$ and 9 . Adequate purification may be obtained by $\mathrm{H}$-saturation only if dissolved silica and chlorides are low. Dissolved silica adds considerably to the ash component and chlorides are converted to $\mathrm{HCl}$ during $\mathrm{H}$-saturation.

One limitation of anion exchange is that some of the organic substances are sorbed by the resin (usually less than 15 percent by dissolved organic carbon analysis). There is virtually no retention of organics on the oation-exchange resin. The organic retention by both resins varies with each particular humic or fulvic acid preparation, but the sorption is usually quite low for the H-resin and moderate for the $\mathrm{OH}$-resin. The decision to use or not to use anion $\mathrm{OH}$-saturation is a compromise on the part of the investigator and is relative to the benefits and limitations of anion exchange and the experimental objectives.

The exchange resins must be kept moist at all times for the resins to retain their activity. After standing in the column for several hours or days, the saturated resins will exchange ions into the interstitial water and must be leached with deionized water before use. Also to facilitate a relatively maintenance-free operation, large column extenders or a continuous flow system are recommended for introducing humic or fulvic acid solutions into the exchange columns.

\section{REFERENCES CITED}

Hori, S. and Okuda, A., 1961, Purification of humic acid by use of ion exchange resin: Soil Sci. and Plant Nutrition, ง. 7, p. 4.

Malcolm, R. I., 1968, Freeze-drying of organic matter, clays, and other earth materials, in Geological Survey research 1968: U.S. Geol. Survey Prof. Paper 600-C, p. C211-C216.

Martin. A. F, and Reeve, R., 1958, Chemical studies of podzolic illuvial horizons: Jour. Soil Sci., v. 9, p. 89-100.

Sliougstad, M. V. and Scarbro, G. F., 1968, Water sample filtration unit: Environmental Sci. and Technology, v. 2, p. 298301. 
Jour. Research U.S. Geol. Survey

Vol. 4, No. 1, Jan.-Feb. 1976, p. 41-47

\title{
BEHAVIOR OF TRACE ELEMENTS DURING MAGMATIC PROCESSES- A SUMMARY OF THEORETICAL MODELS AND THEIR APPLICATIONS
}

\author{
By JOSEPH G. ARTH, Reston, Va.
}

\begin{abstract}
Progress in understanding the behavior of trace elements during the processes that produce igneous rocks has been made possible by the parallel development of theoretical models to describe that behavior and analytical techniques that permit precise measurement of trace-element concentrations in igneous rocks and minerals. The result of this progress is that trace-element studies may now be used to place strong limits on both the degree of partial melting or fractional crystallization involved in the production of a given magma and the identity and quantity of the residual phases. A summary of quantitative trace-element theory and partition coefficient data for igneous rocks is presented.
\end{abstract}

Trace-element studies are now widely used by petrologists and geochemists in the study of igneous rocks, yet many geologists wonder about the basis or validity of petrogenetic conclusions drawn from these studies. While many aspects of trace-element behavior remain unknown, significant progress has been made in both the theory and its experimental and geologic verification. In this paper, the quantitative theory of traceelement behavior during the processes of partial melting and fractional crystallization is summarized for the geologist who has not closely followed the development of this powerful new tool. A simple example of the use of the equations is given, as well as a compilation of phenocryst-groundmass partition coefficient data.

The theoretical models that have been proposed assume as a starting point that trace elements form dilute solid solutions and behave in accordance with Henry's law. This assumption cannot be made, however, where an element, although low in abundance, is a stoichiometric constituent of a phase (for example, zirconium in zircon). Application of Henry's law also depends on the assumption of equilibrium or nearequilibrium conditions. At equilibrium the chemical potential, $\mu$, of element $\mathrm{i}$ in phase $\alpha$ equals the chemical potential of $\mathrm{i}$ in phase $\beta$ :

$$
\mu_{\mathrm{i}}^{\alpha}=\mu_{1}^{\beta} \text {. }
$$

This can be restated in terms of the activity, $a$, and the chemical potential for the standard state, $\mu^{\circ}$, as: $\mu^{\circ}{ }^{a}+R T \ln a_{1}^{a}=\mu^{\circ}{ }_{i}^{\beta}+R T \ln a_{1}^{\beta}$.

Algebraic manipulation yields the equation

$$
\exp \left(\frac{\mu_{1}^{\circ}{ }^{a}-\mu^{\circ}{ }_{1}^{\beta}}{R T}\right)=a_{1}^{\beta} / a_{1}^{a}=\mathrm{k} .
$$

The first part of this equation is constant if the temperature, pressure, and bulk composition are constant, so that the ratio of activities will equal a constant, $\mathrm{k}$. The activities can be restated in terms of elemental concentrations, $c$, and activity coefficients, $\gamma$, to produce the following:

$$
\gamma_{\mathrm{i}}^{\beta} c_{1}^{\beta}=\mathrm{k} \gamma_{\mathrm{i}}^{a} c_{1}^{a} .
$$

According to Henry's law the activity coefficients have a constant value which is independent of concentration so long as the solution is dilute, so that

$$
\frac{c_{1}{ }^{\alpha}}{c_{\mathbf{i}^{\beta}}{ }^{\beta}}=\frac{\gamma_{1}{ }^{\beta}}{\mathrm{k}_{\gamma_{1}{ }^{\alpha}}}=K^{\alpha / \beta} .
$$

The quantity $K^{\alpha / \beta}$ is called the distribution coefficient and simply represents the concentration ratio of a trace element between two equilibriated phases. The concentration of a trace element in a magma, therefore, is expected to reflect the value of the distribution coefficient between the magma and the solid phases with which it coexists. The expected effects on the distribution coefficient of temperature, pressure, crystallographic site, and magma composition have been discussed by McIntire (1963) and Banno and Matsui (1973), but are experimentally confirmed for only a few elements in a few minerals and over very limited ranges of temperature, pressure, and composition.

\section{PARTIAL MELTING}

Equations describing the behavior of trace elements during partial melting were formulated by Schilling and Winchester (1967) and Gast (1968). Shaw (1970) later devised less complicated expressions which describe three possible partial-melting mechanisms: (1) continuous removal of melt from the residual solid, (2) continuous removal of melt from the residual solid followed by collection of this melt in a single 
completely mixed chamber, and (3) continuous equilibrium of the liquid phase with the residual solid until removal of the liquid from the solid (sometimes referred to as "batch" melting). When small fractions of material are melted, the equations for each mechanism yield similar results. When large fractions of material are melted ( $>25$ percent) results of the equations vary considerably. As the continuous removal of infinitesimal amounts of liquid (Nos. 1 and 2 ) is often considered physically unlikely, mechanism 3 may be the most geologically realistic for large bodies of magma of uniform composition.

For partial melting in which the liquid phase remains in equilibrium with the residual solid phases until it is removed (No. 3), equation 15 of Shaw (1970) gives.

$$
\frac{c^{L}}{c_{0}}=\frac{1}{D_{0}+F(1-P)}
$$

where $F$ is the fraction of melting, $c_{0}$ the initial traceelement concentration of the solid, and $c^{L}$ the traceelement concentration of the liquid. $D_{0}$ is the bulk distribution coefficient for the starting assemblage and is given by Shaw's equation 6 as

$$
D_{0}=X_{0}{ }^{a} K^{a / L}+X_{0}{ }^{\beta} K^{\beta / L}+\ldots
$$

where $X_{0}{ }^{\alpha}$ is the initial weight fraction of phase $\alpha$, $X_{0}{ }^{\beta}$ the initial weight fraction of phase $\beta$, and $K^{\alpha / L}$ is the solid-liquid distribution coefficient for phase $\alpha, K^{\beta / L}$ the solid-liquid distribution coefficient for phase $\beta$. The term $P$ is given by

$$
P=p^{a} K^{\alpha / L}+p^{\beta} K^{\beta / L}+\ldots
$$

where $p^{a}, p^{\beta}$, and so forth are the fraction of liquid contributed by each phase during melting. For the unusual case when simple modal melting takes place (in other words, when the percentage of each phase in the solid does not change during melting), $P=D_{0}$, and equation 1 reduces to

$$
\frac{c^{L}}{c_{0}}=\frac{1}{D_{0}+F\left(1-D_{0}\right)} \text {. }
$$

In figure $1, c^{L} / c_{0}$ is plotted against the extent of partial melting for residues having $D_{0}$ values of 0 to 10 . When the bulk distribution coefficient approaches zero, equation 1 reduces to

$$
\frac{c^{L}}{c_{0}} \approx \frac{1}{F}
$$

so that the concentration of an element in the liquid depends solely on the extent of partial melting. Where $D_{0}=0$ (fig. 1), an upper limit is provided for the concentration that can result by partial melting of a given solid. When two elements have small distribution coefficients, the ratio of these elements in the liquid will

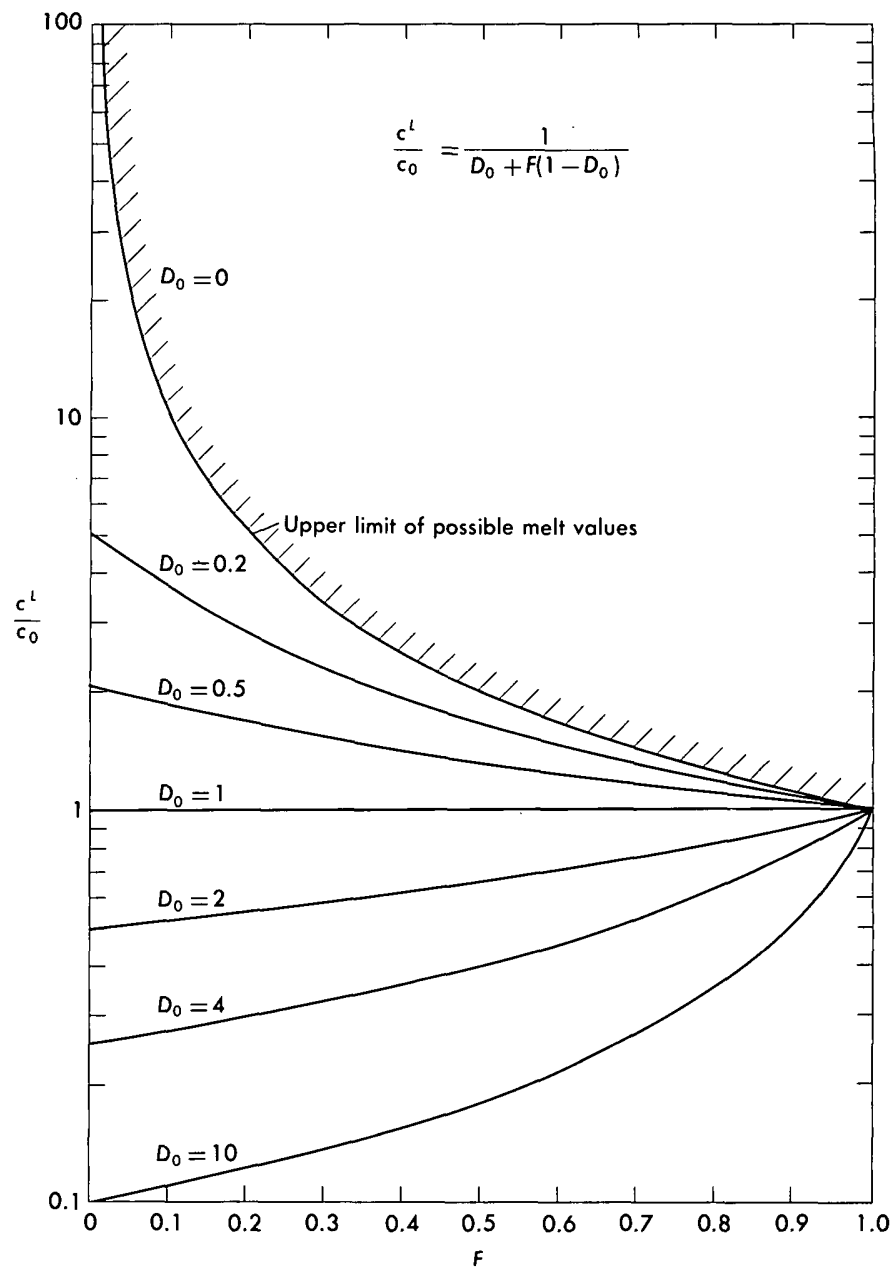

Figure 1.-Illustration of the behavior of a trace element during partial melting predicted by the "modal melting" equation of Shaw (1970) for liquid which is in continuous equilibrium with residual solid until it is removed as a "batch." $F$, fraction of melting; $c_{0}$, initial trace-element concentration of the solid; $c^{L}$, trace-element concentration of liquid; $D_{0}$, bulk distribution coefficient for the starting assemblage.

be the same as that in the parent. Where $F$ approaches 0 or is much smaller than $D_{0}$, equation 1 or 4 reduces to

$$
\frac{c^{L}}{c_{0}} \approx \frac{1}{D_{0}}
$$

The larger the value of $D_{0}$, the greater will be the extent of melting for which this relation holds. For example, when $D_{0}=10$ (fig. 1 ), $c^{L} / c_{0}$ has a value of about 0.1 for nearly 30 percent melting.

Also of importance during partial melting is the influence of minor phases. No phase, major or minor, that is present in an assemblage before melting will exert any control on the trace-element content or ratios of the melt if it is not a residual phase when the melt is separated. A consequence of this is that the modal 
melting model can be used to predict liquid concentrations when the identity of early melting phases is unknown, but when the mineralogical composition of the residue can be exactly specified for the specific degree of melting at which the separation of liquid occurs.

In applying the equations discussed above, the most useful results are obtained when the trace elements studied have a broad range of distribution coefficients for the various rock-forming minerals. If an element has a value of $D_{0}$ that approaches zero for a given residual mineral assemblage, equation 5 provides an estimate of the extent of partial melting. If an element has a value of $K^{a / L}$ that is large for one residual mineral and small for the other residual minerals, then a determination of the percentage of that mineral in the residue can be made for small degrees of melting, because equation 2 can be approximated as $D_{0} \approx$ $X_{0}{ }^{a} K^{a / L}$, and equation 6 can be written as

$$
X_{0}{ }^{a}=\frac{c_{0}}{c^{L} K^{a / L}} .
$$

If the distribution coefficients are significantly different for two trace elements in a single mineral, the presence of that mineral in the residue can be determined. For example, consider the behavior of $\mathrm{K}$ and $\mathrm{Rb}$ during partial melting of an ultramafic assemblage containing olivine, pyroxene, and amphibole, when $K$ is present in trace amounts. Both olivine and pyroxene have solid-liquid distribution coefficients for $\mathrm{K}$ and $\mathrm{Rb}$ that are close to zero (table 1), whereas the amphiboleliquid coefficient for $K$ is close to one and that for $R b$ is about 0.3. Thus, during partial melting, residual olivine and pyroxene will retain almost no $R b$ or $K$, while residual amphibole rejects $R b$ more strongly than $K$. The result is a liquid that is enriched in $R \mathbf{b}$ more than $K$ and that has a lower $K: R b$ ratio than that of the parent assemblage. Thus, a low $K: R b$ ratio in a magma may suggest the presence of residual amphibole. If amphibole does not remain in the residue but is all reacted or melted, the $K: R b$ ratio will be close to that of the parent as neither olivine nor pyroxene retain $K$ or $R b$.

If $K$ and $R b$ were major elements in this example, early melting of amphibole, which usually has a high $\mathrm{K}: \mathrm{Rb}$ ratio, would produce a small fraction of melt of high $K: R b$ ratio. The high ratio for the melt would be lowered to that of the original parent solid as melting continued. It is thus important to determine whether the elements under consideration are major or trace elements for the composition in question. Unfortunately, criteria for this distinction in real magma systems are yet to be adequately defined.

\section{FRACTIONAL CRYSTALLIZATION}

Equations governing trace-element behavior during fractional crystallization assume equilibrium either between the surface of the crystallizing phases and the melt or between the total solid and the melt. The surface equilibrium models are based on the quantitative description of the distillation process developed by Rayleigh (1896) as applied to crystal growth from solution by Doerner and Hoskins (1925). These equations were first applied to magmatic differentation by Neumann (1948), Holland and Kulp (1949), and Neumann, Mead and Vitaliano (1954), and were refined by Greenland (1970) and Albarede and Bottinga (1972).

The equation describing trace-element behavior during fractional crystallization given by Greenland (1970) may be written (for the simplified case of crystallization of phases in constant proportions with constant distribution coefficients) as

$$
\frac{c_{L}}{C_{i}}=F^{\prime\left(D_{s}-1\right)}
$$

$F^{\prime}$ is the fraction of liquid remaining, $c_{1}$ is the concentration of the original melt, $c_{L}$ is the concentration in the differentiated liquid, and $D_{8}$ is the bulk distribution coefficient given by

$$
D_{s}=W^{a} K^{a / L}+W^{\beta} K^{\beta / L}+\ldots,
$$

where $K$ is the solid-liquid partition coefficient and $W^{a}$ represents the weight fraction of $\alpha$ in the precipitating phases (fig. 2) As in the case of partial melting, when $D_{s}$ approaches zero,

$$
\frac{c_{L}}{c_{1}} \approx \frac{1}{F^{\prime}}
$$

so that the concentration of an element depends only on the extent of solidification. Thus, the line marked $D_{s}=0$ (fig. 2) forms an upper limit to the concentration that a fractionated liquid may contain for a given percentage crystallized. If, on the other hand, $D_{\&}$ is very large, then the liquid will be very rapidly depleted. This is illustrated by the line marked $D_{s}=10$ in figure 2.

It is of interest to compare the relative magnitude of depletion and enrichment that occurs during surface-equilibrium fractional crystallization with that which occurs during partial melting. For a large value of $D_{\mathrm{s}}$ or $D_{0}$ (for example, $D_{\mathrm{s}}$ or $D_{0}=10$ ), fractional crystallization (fig. 2) can produce a greater depletion in the melt than partial melting (fig. 1). Similarly, for a value of $D_{\mathrm{s}}$ or $D_{0}$ which is less than 1 (for example, $D_{s}$ or $D_{0}=0.5$ ), fractional crystallization (fig. 2) 


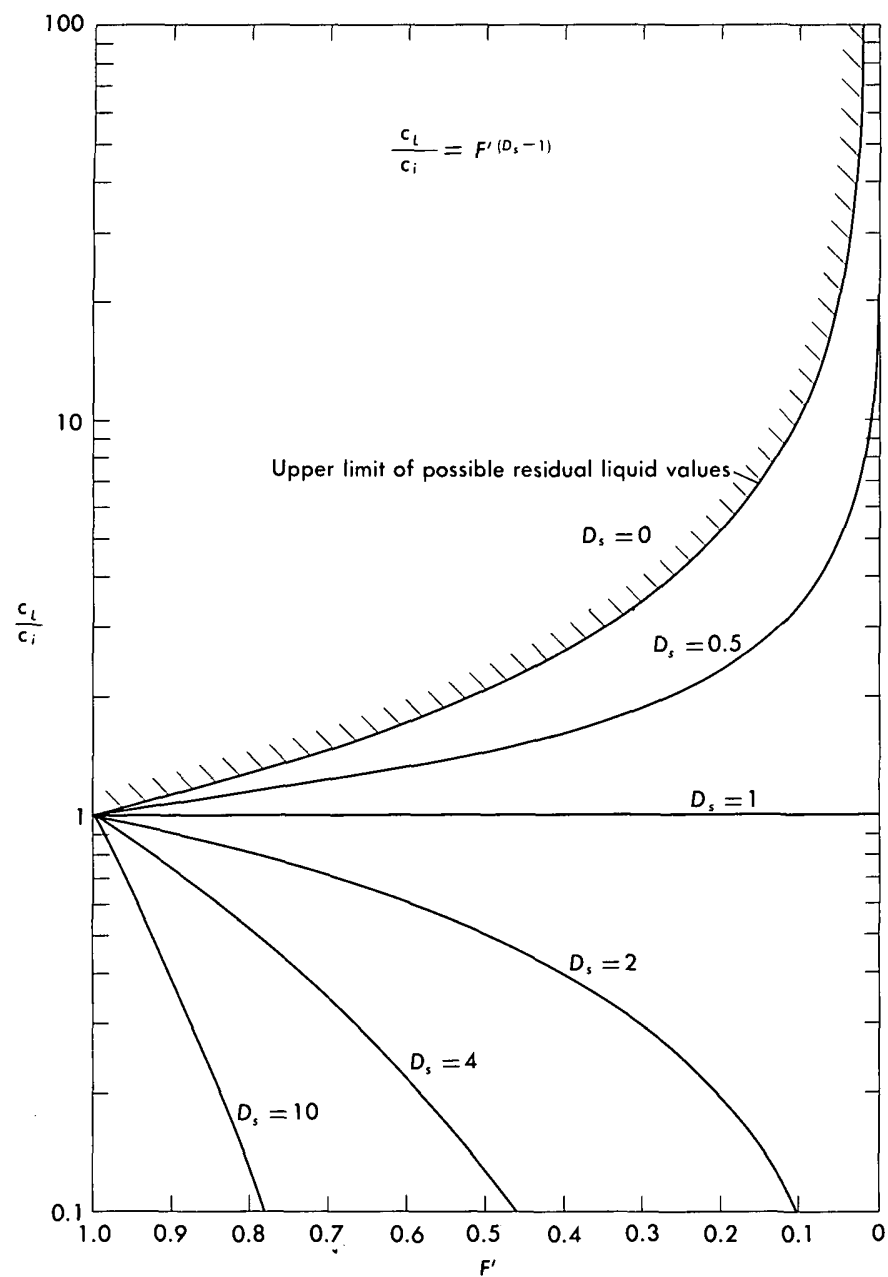

F'IGURE 2.-Illustration of the behavior of a trace element predicted by a Rayleigh fractionation model for fractional crystallization from a liquid of phases in constant proportions and having constant distribution coefficients. $F^{\prime}$, fraction of liquid remaining; $c_{i}$, concentration of the original melt; $c_{L}$, concentration in the differentiated liquid; $D_{s}$, bulk distribution coefficient for the residual solid.

can produce greater enrichment than partial melting (fig. 1).

The second description of fractional crystallization assumes equilibrium between the total crystallizing solid and melt. This is expressed as

$$
\frac{c_{L}}{c_{i}}=\frac{1}{F^{\prime}+D_{s}\left(1-F^{\prime}\right)}
$$

with symbols as previously defined. This equation is analogous to the total equilibrium partial melting models (eq. 1) ; figure 1 can be used to represent this case graphically if the abscissa scale is reversed to read from 1.0 to 0 and $D_{0}$ values are read as $D_{s}$ values. The surface-equilibrium model may be more applicable to rapidly cooling, shallowly emplaced magmas, whereas the total equilibrium model may better de- scribe plutonic conditions where the cooling of an intruded magma is extremely slow, so that the crystallizing phases may be in total equilibrium with the melt (Rittman, 1973, p. 18).

\section{DISTRIBUTION COEFFICIENTS}

Quantitative application of the models above depends strongly on the availability of accurately determined distribution coefficients. Several approaches have been utilized in attempting to determine the absolute value of distribution coefficients, the principal ones including experimental studies in the mineralaqueous vapor system, microprobe studies of strongly doped experimentally grown crystals and quench glass, and measurement of concentrations in separated phenocrysts and groundmass from volcanic rocks. Some of the severe problems incurred in utilizing the mineralaqueous vapor system are illustrated by Zielinski and Frey (1974). Microprobe studies may prove useful, although doping of the experimental materials in sufficient quantity to detect the trace elements by microprobe may remove them from the concentration levels at which Henry's law is thought to apply. Phenocrystmatrix studies such as those of Philpotts and Schnetzler (1970) provide a body of "real world" data. These data are thought to approximate the true values, but they incur problems such as the effects of crystal zonation, as illustrated by Albarede and Bottinga (1972).

$\mathrm{Rb}, \mathrm{Sr}, \mathrm{Ba}$, and rare-earth elements are among the most useful at this time because their phenocrystmatrix coefficients have been precisely measured for a variety of minerals in various rock types. The data for $\mathrm{Rb}, \mathrm{Sr}, \mathrm{Ba}$, and rare earths are summarized in tables $1-3$. The average and range for the determinations are given. Many partition coefficients vary in value by more than an order of magnitude; but refinement should be possible after careful evaluation has been made of the effects of temperature, pressure, crystallographic site, and magma composition. In spite of the large lange of values, rare-earth elements, when considered as a group, show remarkably consistent partition coefficient pattems for a given mineral (see, for example, Schnetzler and Philpotts, 1970). Residues containing these minerals will thus produce characteristic fractionations in the rare-earth patterns of associated magmas.

\section{NEED FOR ANALYTICAL PRECISION}

The usefulness of trace elements is enhanced by their large range of natural abundance, especially when they are measured precisely and accurately, as for example, when the method of isotope-dilution mass-spec- 
TABLE 1.-Partition coefficients for basaltic and andesitic rocks

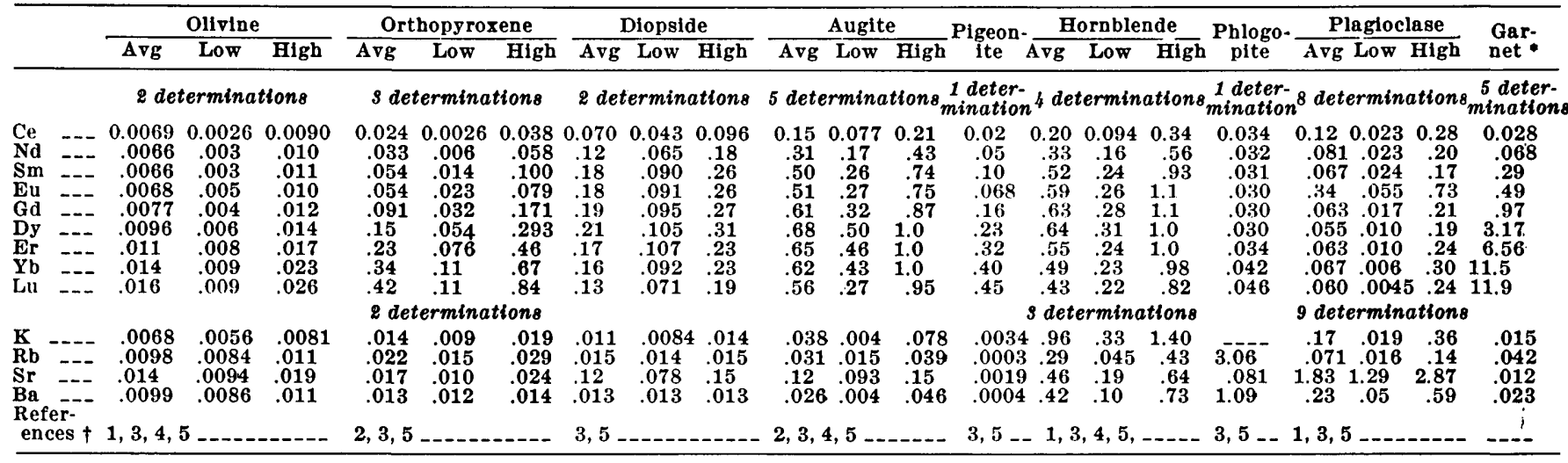

* Garnet values obtained by multiplying average garnet/clinopyroxene of reference 6 by average augite/liquid of this table.

$\dagger$ References are as follows:

1. Higuchi and Nagasawa (1969).

2. Onuma and others (1968)

3. Philpotts and Schnetzler (1970).

5. Schnetzler and Philpotts (1968).

6. Philpotts and other (1972).

TABLE 2.-Partition coefficients for dacitic rocks [Data represent one determination per mineral]

\begin{tabular}{|c|c|c|c|c|}
\hline & Garnet & Biotite & Plagioclase & Hornblende \\
\hline $\mathrm{Ce}$ & 0.35 & 0.037 & 0.24 & 0.899 \\
\hline Nd & .53 & .044 & .17 & 2.80 \\
\hline $\mathrm{Sm}$ & 2.66 & .058 & .13 & 3.99 \\
\hline Eu & 1.50 & .145 & 2.11 & 3.44 \\
\hline Gd & 10.5 & .082 & .090 & 5.48 \\
\hline Dy & 28.6 & .097 & .086 & 6.20 \\
\hline Er & 42.8 & .162 & .084 & 5.94 \\
\hline Yb & 39.9 & .179 & .077 & 4.89 \\
\hline Lu & 29.6 & .185 & .062 & 4.53 \\
\hline K & .020 & & .263 & \\
\hline $\mathbf{R b}$ & .0085 & 3.26 & .048 & \\
\hline $\mathrm{Sr}$ & .015 & .12 & 2.84 & \\
\hline $\mathrm{Ba}$ & .017 & 6.36 & .36 & \\
\hline References* _ & $1,2 \ldots$ & $1,2_{-}$ & $1,2_{-}$ & 3 \\
\hline
\end{tabular}

References are as follows:

1. Philpotts and Schnetzler (1970).

3. Arth, unpub. data, 1975 . trometry is used. 'The need for accurate and precise data is perhaps best illustrated by a simple hypothetical example. 'Two laboratories measure the concentration of $\mathrm{Rb}$ in a sample from a large homogeneous body of basalt. The precise laboratory reports $\mathrm{Rb}$ and $\mathrm{Sr}$ values of $5.0 \pm 0.1 \mathrm{ppm}$ and $150 \pm 3 \mathrm{ppm}$, whereas the second laboratory, using a less precise technique, reports $\mathrm{Rb}$ and $\mathrm{Sr}$ values of $5 \pm 4 \mathrm{ppm}$ and $150 \pm 30 \mathrm{ppm}$. Near the basalt is a large uniform dacite flow, the origin of which is not clear, but two hypotheses have been advanced: (1) partial melting at great depth of a rock of composition similar to that of the basalt at the surface, leaving a residue containing equal amounts of garnet and clinopyroxene or (2) fractional crystallization of equal amounts of plagioclase and clinopyroxene from

TABLE 3.-Partition coefficients for rhyolitic rocks

[Figures in parentheses indicate number of determinations]

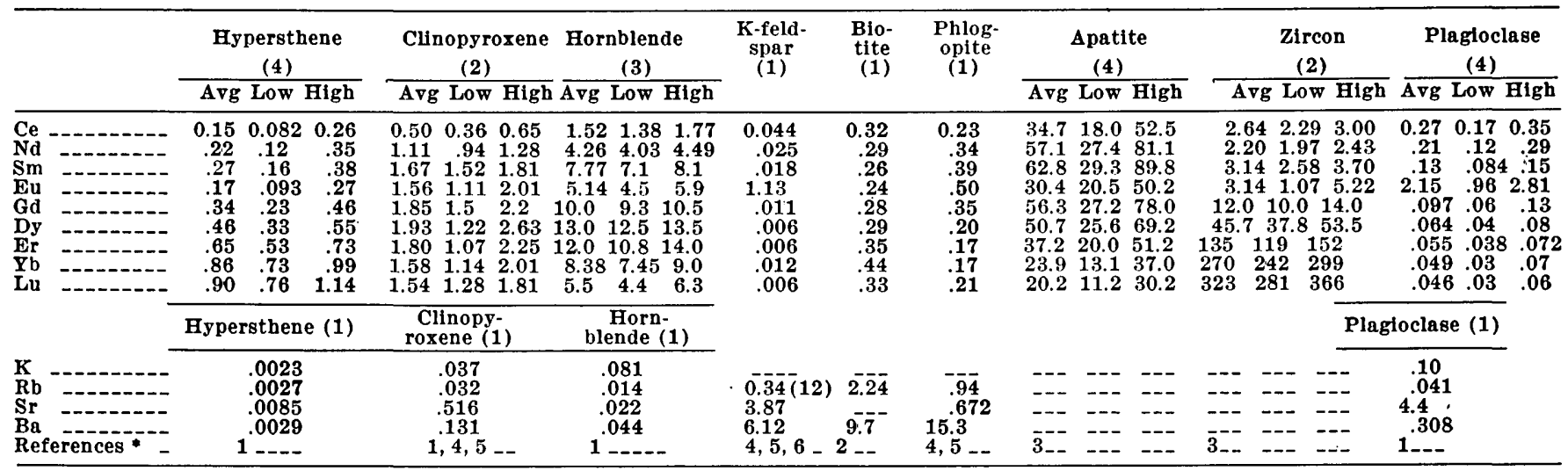

- References are as follows

1. Nagasawa and Schnetzler (1971)
2. Higuchi and Nagasawa (1969).
3. Nagasawa $(1970)$.
4hilpotts and Schnetzler (1970).
5. Schnetzler and Philpotts (1970).

6. Noble and Hedge (1970). 
the basaltic liquid. Each laboratory produces a $\mathrm{Rb}$ and $\mathrm{Sr}$ measurement for the dacite, the first reporting $35 \pm 0.7 \mathrm{ppm} \mathrm{Rb}$ and $500 \pm 10 \mathrm{ppm} \mathrm{Sr}$, the second reporting $35 \pm 4 \mathrm{ppm} \mathrm{Rb}$ and $500 \pm 100 \mathrm{ppm} \mathrm{Sr}$. The result of calculating each of these two models is shown in figure 3. The precise data suggest that neither simple mechanism is correct. whereas the imprecise data allow that the partial melting model is a possibility. Clearly, the validity of conclusions based on imprecise analytical data is subject to question, yet a surprising number of geochemists continue to publish and allow publication of data of poor precision and accuracy. One might argue that we do not yet know partition coefficients sufficiently well to justify rock analyses of great precision. However, we never will know distribution coefficients well without precise and accurate measurement, and when and if we do attain this goal, only the precise data in the literature will be of any value.

\section{REFERENCES CITED}

Albarede, F., and Bottinga, Y., 1972, Kinetic disequilibrium in trace element partitioning between phenocrysts and host lava : Geochim. et Cosmochim. Acta, v. 36, no. 2, p. 141-156.

Banno, Shohei, and Matsui, Yoshito, 1973, On the formulation. of partition coefficients for trace elements distribution between minerals and magma: Chem: Geology, v. 11, no. 1, p. 1-15.

Doerner, H. A., and Hoskins, W. M., 1925, Coprecipitation of radium and barium sulfates: $\Lambda \mathrm{m}$. Chem. Soc. Jour., v. 47, p. $662-675$.

Gast, P. W., 1968, Trace element fractionation and the origin of tholeiitic and alkaline magma types: Geochim. et Cosmochim. Acta, v. 32, no. 10, p. 1057-1086.

Greenland, L. P., 1970, An equation for trace element distribution during magmatic crystallization: Am. Mineralogist, v. $55, \operatorname{nos} .3-4$, p. $455-465$.

Higuchi, Hideo, and Nagasawa, Hiroshi, 1969, Partition of trace elements between rock-forming minerals and the host volcanic rocks: Earth and Planetary Sci. Letters, v. 7 , p. $281-287$.

Holland, H. D., and Kulp, J. L., 1949, The distribution of acces. sory elements in pegmatites-I, Theory : Am. Mineralogist, v. 34, nos. 1-2, p. 35-60.

McIntire, W. L., 1963, Trace element partition coefficientsA review of theory and applications to geology : Geochim. et Cosmochim. Acta, v. 27, no. 12, p. 1209-1264.

Nagasawa, Hiroshi, and Schnetzler, C. C., 1971, Partitioning of rare earth, alkali and alkaline earth elements between phenocrysts and acidic igneous magma: Geochim. et Cosmochim. Acta, v. 35 , no. 9 , p. $953-968$.

Nagasawa, Hiroshi, 1970, Rare earth concentrations in zircons and apatites and their host dacites and granites: Earth and Planetary Sci. Letters, r. 9, no. 4, p. 359-364.

Neumann, Henrich, 1948, On hydrothermal differentiation: Econ. Geology, v. 43, no. 2, p. 77-83.

Neumann, Henrich, Mead, Judson, and Vitaliano, C. J., 1954. Trace element variation during fractional crystallization
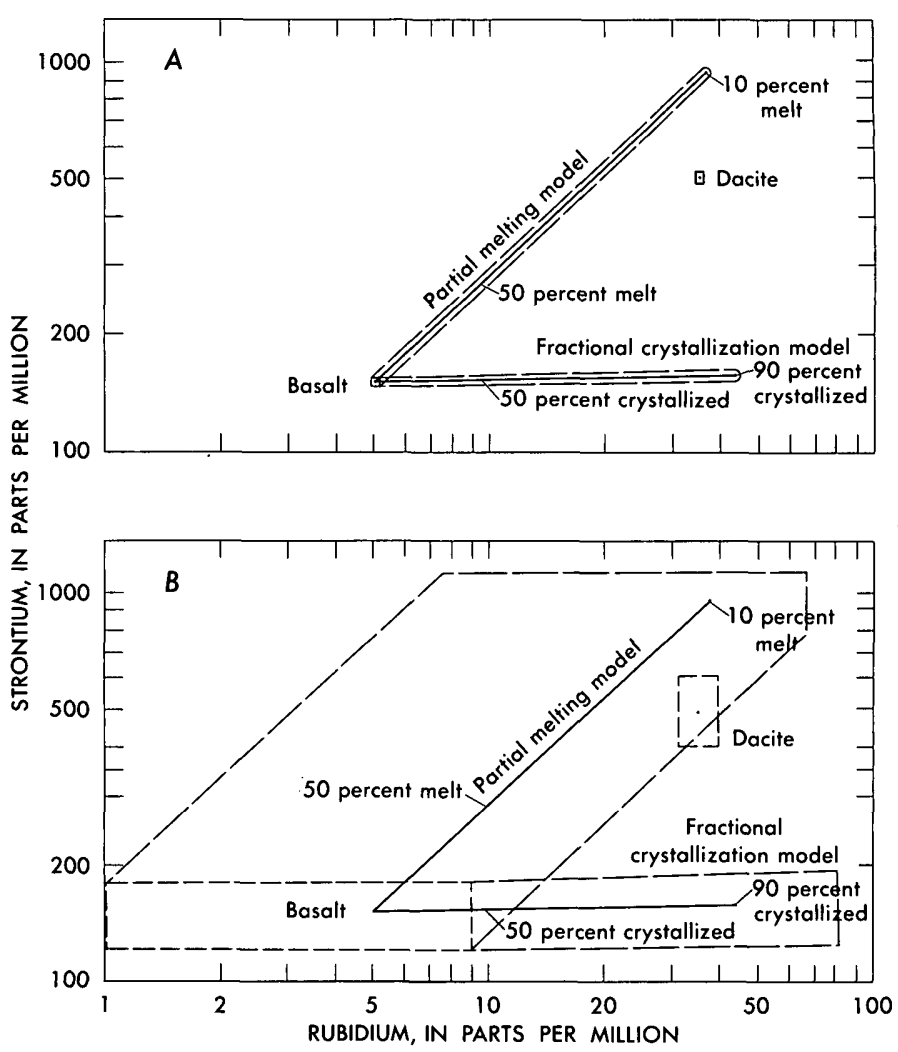

Figure 3.-Illustration, of the need for precise analyses, as explained in the text. 'A, Model constructed from precise data. $B$, Model constructed from imprecise data. Solid lines represent model values dashed lines, the uncertainties based only on the precision of the analyses, but not including uncertainties in the partition coefficients.

as calculated from the distribution law: Geochim. et Coschim. Acta, y. 6 , nos. 2-3, p. 90-99.

Noble, D. C., and Hedge, C. E., 1970. Distribution of rubidium between sodic sanidine and natural silicic liquid: Contr. Mineralogy and Petrology, v. 29, no. 3, p. 234-241.

Onuma, N., Higuchi, H., Wakita, H., and Nagasawa, H., 1968, Trace element partition between two pyroxenes and the host volcanic rocks: Earth and Planetary Sci. Letters, v. 5, 47-51.

Philpotts, J. A., and Schnetzler, C. C., 1970, Phenocryst-matrix partition coefficients for $\mathrm{K}, \mathrm{Rb}, \mathrm{Sr}$ and $\mathrm{Ba}$, with applications to anorthosite and basalt genesis: Geochim. et Cosmochim. Acta, v. 34, p. 307-322.

Philpotts, J. A., Schnetzler, C. C., and Thomas, H. H., 1972, Petrogenetic implications of some new geochemical data on eclogitic and ultrabasic inclusions : Geochim. et Cosmochim. Acta, r. 36, no. 10, p. 1131-1166.

Rayleigh, J. W. S., 1896, Theoretical considerations respecting the separation of gases by diffusion and similar processes: Philos. Mag., v. 42, p. 77-107.

Rittman, Alfred, 1973, Stable mineral assemblages of igneous rocks. Springer-Verlag, p. 16-19.

Schilling. J. G., and Winchester, J. W., 1967, Rare-earth fractionation and magmatic processes, in Runcorn, S. K., ed., Mantles of the Earth and terrestrial planets : London and New York, Interscience Publishers, p. 267-283. 
Schnetzler, C. C., and Philpotts, J. A., 1968, Partition coeffcients of rare-earth elements and barium between igneous matrix material and rock-forming-mineral phenocrystsI, in Ahrens, L. H., ed., Origin and distribution of the elements: Oxford, England, and New York, Pergamon Press, p. 929-938

Schnetzler, C. C., and Philpotts. J. A., 1970, Partition coeffcients of rare-earth elements between igneous matrix material and rock-forming-mineral phenocrysts-II: Geochim. et Cosmochim. Acta, v. 34, no. 3, p. 331-340.

Shaw, D. M., 1970, Trace element fractionation during anatexis: Geochim, et Cosmochim. Acta, v. 34, no. 2, p. $237-243$.

Zielinski, R. A., Frey, F. A., 1974, An experimental study of partitioning of a rare-earth element (Gd) in the system diopside-aqueous vapour: Geochim. et Cosmochim. Acta, v. 38 , p. $545-565$. 


\section{.}




\title{
TRACE-METAL VARIATION IN SOILS AND SAGEBRUSH IN THE POWDER RIVER BASIN, WYOMING AND MONTANA
}

\author{
By JON J. CONNOR, JOHN R. KEITH, and BARBARA M. ANDERSON, \\ Denver, Colo.
}

\begin{abstract}
A reconnaissance study of 28 trace metals in samples of surface soil $(0-2.5 \mathrm{~cm}$ deep), subsurface soil (15$20 \mathrm{~cm}$ deep), and big sagebrush (Artemisia tridentata) that were collected from the Powder River Basin in Wyoming and Montana indicates that little variation occurs in nature at scales greater than about $35 \mathrm{~km}$. This general lack of broadscale variation suggests that simple summary statistics for these materials could provide basinwide geochemical baselines for use in monitoring secular changes in the local geochemical environment. Samples of big sagebrush near the Dave Johnston Power Plant at the southern edge of the basin exhibit statistically significant reductions of strontium, vanadium, uranium, and selenium eastward from the plant.
\end{abstract}

The anticipated development of a large, coal-based electric power industry in the Powder River Basin of Wyoming and Montana has focused a great deal of attention on the potential environmental effects. One of the probable impaots is that of secular changes in the geochemical environment resulting from extensive mining and burning of coal. While it might be anticipated that effects of mining and combustion may dramatically change the geochemical environment in the immediate vicinity of the activities, less dramatic changes which might take place far from the disturbed areas would be much more difficult to identify. Such changes would be best monitored by the establishment of predevelopment geochemical "baselines" for the basin.

A geochemical baseline might be defined in various ways, but a mandatory requirement of any such definition is that it take into account the predominant scales of geochemical variability inherent in nature. This report describes a reconnaissance study of the trace-metal geochemistry of surface soil, subsurface soil and sagebrush in the Powder River Basin. We have attempted to describe the magnitude of geochemical variation in three natural materials of the basin, to estimate in an approximate way the predominant scales of variation, and to suggest the kind and amount of work necessary to establish geochemical baselines of a stated validity.

\section{PHYSIOGRAPHIC SETTING}

The Powder River Basin is bounded by the Black Hills on the east, by the Laramie Mountains on the south, and by the Bighorn Range on the west. On the north it merges with the Great Plains and is physiographically indistinguishable from the plains. The area of the basin is approximately $52,000 \mathrm{~km}^{2}$ and is characterized by rolling low hills with high hills and badlands along the larger drainages. The average altitude of the basin is approximately $1,500 \mathrm{~m}$ and total relief is about $1,400 \mathrm{~m}$.

The Powder River Basin is geologically similar to other large intermountain basins in the northern Rocky Mountain region. As much as $5,000 \mathrm{~m}$ of sediments are preserved in the basin (McGregor, A. A., 1972, p. 269), of which perhaps $1,700-2,300 \mathrm{~m}$ are early Tertiary in age. The Tertiary rocks underlie most of the surface area of the basin; they consist largely of shale and sandstone and contain most of the coal.

'The soils in the Powder River Basin outside of the Powder River valley proper tend to be silty or sandy with small or moderate zonal development. They appear to include large amounts of eolian and colluvial material. The most common soil in the basin is classified as a Haplargid (U.S. Geol. Survey, 1970, p. 86). Typically, such soils have a loamy horizon of clay accumulation, are low in organic matter and are rarely moist for more than three consecutive months. Torriorthents (Lithosols), which lack pedogenic horizons, are common in the northern part of the basin.

The vegetation of the Powder River Basin (Küchler, 1964 ) is principally grass (Agropyron smithii, Bouteloua gracilis, and Stipa comata) with occasional stands of pine (Pinus ponderosa) and juniper (Juniperus sp.), particularly in the central part of the basin. The flood plains of the Powder River and its tributaries are densely vegetated with cottonwood (Populus sargentii) and willow (Salix sp.) where not modified by agricul- 
ture. Growing throughout the basin are a number of species of sagebrush, including Artemisia tridentata which was chosen as a target species for the botanical part of this study.

\section{METHODS OF SAMPLE COLLECTION AND PREPARATION}

All samples of bedrock, soil, and sagebrush were collected in May 1973. All plant material was clipped from the crown of a living sagebrush plant and stored in quart-size refrigerator-freezer boxes for shipment. In the laboratory, the plant tissue was ashed and analyzed for a variety of metals using emission spectrographic and atomic absorption techniques. The element selenium was determined on dry plant material.

Except for the samples taken in the three profiles, which were channeled with the chisel end of a geologic hammer, all soil samples were collected using a chromeplated trowel and were stored in paper soil envelopes. In the laboratory, these samples were dried at $45^{\circ} \mathrm{C}$ for one week, pulverized in a ceramic mill, and sieved to obtain the $<2$-mm fraction. All larger particles were discarded. The soils were analyzed using emission spectrographic and neutron activation techniques.

The rock and soil samples from the three profiles were collected with a geologic hammer and were stored in cloth bags. These samples were subjected to no special handling prior to elemental analysis which was performed using the same methods as described for the soils (above).

In order to circumvent any potential effects of systematic laboratory error, all rock, soil, and plant samples were analyzed in a randomized sequence. The samples were prepared and analyzed in laboratories of the U.S. Geological Survey in Denver.

\section{TRACE-METAL VARIATION IN SOILS AND SAGEBRUSH}

\section{Geographic variation}

This part of the study, referred to as the basinwide study, was an assessment of scale-related components of trace-metal variation in soil and sagebrush of the basin. The area of the basin (fig. 1) was arbitrarily subdivided into 12 rectangular units of about 50 by 80 $\mathrm{km}$ ("supertownships"). Within each supertownship, two townships and three sections within those townships were selected by a randomization procedure. One of the sections in each township was randomly selected for duplicate sampling. In these, two localities up to $300 \mathrm{~m}$ apart were sampled. This design utilizes a special case of the analysis of variance and is described in detail in a later part of this report.

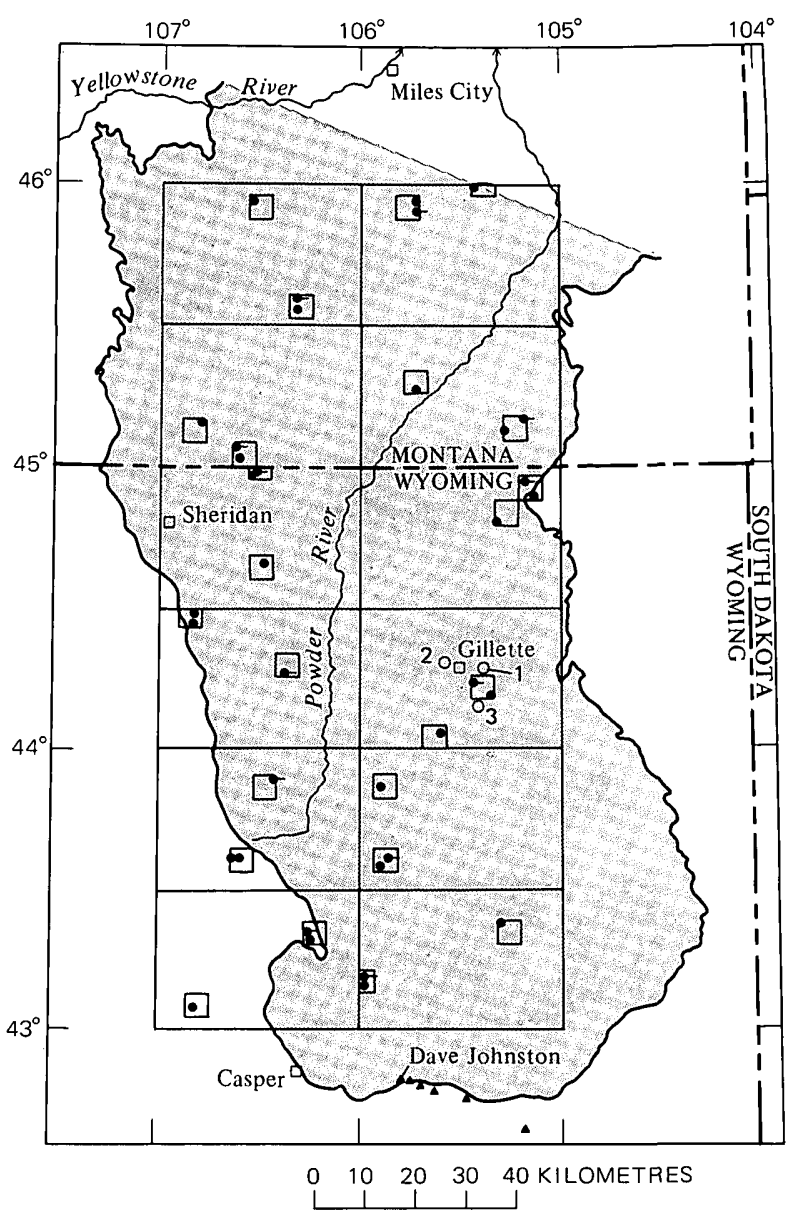

Figure 1.-Index map showing sampling localities in the Powder River Basin (patterned). Solid dots, sampling localities (sections) used in the basinwide study; solid dots with ticks, duplicate sampling localities; numbered open circles, sampling localities used in the profile study; solid triangles, sampling localities used in the powerplant study. Rectangles, "supertownships"; squares, townships.

Three kinds of samples were collected at each of the 48 localities sampled in the basinwide study: (1) a sample of about $50 \mathrm{~g}$ of the terminal stems and leaves from a single sagebrush plant, (2) a sample of about $200 \mathrm{~g}$ of the upper $2.5 \mathrm{~cm}$ of vegetation-free soil as close as practical to the sampled plant, and (3) a sample of soil of about $200 \mathrm{~g}$ from 15 to $20 \mathrm{~cm}$ below the surface at the same point as the sample in 2. The distribution of sagebrush prevented the collection of a single species throughout the basin. However, big sagebrush (Artemisia tridentata) was sampled at 41 of the 48 localities, and the trace-metal chemistry of these 41 samples was used to assess trace-element variability in an indigenous shrub.

Four components of scale-related logarithmic variance in the Powder River Basin are listed in table 1 
under "Basinwide study." $S_{\log x}^{2}$ estimates the total logarithmic variance observed for each metal in each listed material, $S^{2}{ }_{B}$ estimates the logarithmic variance attributable to factors operating over scales greater than $35 \mathrm{~km}$ (the expected distance between two randomly selected townships within a supertownship), $S^{2}{ }_{T}$ and $S^{2}$ s estimate the logarithmic variance attributable to factors operating over scales of $4.5-35$ and $0.3-45 \mathrm{~km}$, respectively, and $S^{2}{ }_{L}$ estimates the logarithmic variance attributable to factors operating over scales less than $0.3 \mathrm{~km}$. The last entry in this part of table $1, S_{E}^{2}$, estimates the logarithmic variance arising in the laboratory

The components of variance, and the percentage of the total variance represented by each, clearly demonstrate the importance of small-scale ("local") tracemetal variation in soils and in Artemisia tridentata in the Powder River Basin. Of 60 entries in the basinwide study only 15 exhibit components at scales larger than $0.3 \mathrm{~km}$ which are significantly different from zero at the 0.05-probability level. In particular, none of the estimates of $S^{2}{ }_{B}$ are significantly different from zero and only seven estimates of $S^{2} r$ are judged to be significantly different from zero-that of barium in surface soil and those of chromium, cobalt, lead, nickel, uranium, and vanadium in sagebrush ash. These estimates indicate that samples of soil and sagebrush collected at opposite ends of the basin will differ, on the average, little more than samples taken about $35 \mathrm{~km}$ apart and, for many metals, will differ little more than samples taken only $4.5 \mathrm{~km}$ apart.

\section{Vertical variation in soils}

A second part of the reconnaissance study in the Powder River Basin consisted of an examination of trace-metal variation in three vertical profiles of surface material near Gillette, Wyo. (profiles 1-3, fig. 1). Each profile consists of about $100 \mathrm{~cm}$ of weakly stratified surficial or soil-like material overlying a sandy substrate. The deepest profile sampled (profile 1, fig. 1) was in the wall of a ditch at the Wyodak mine near Gillette where some $300 \mathrm{~cm}$ of bedded sandstone, shale, and conglomerate were exposed beneath the soil. All three profiles down to about $100 \mathrm{~cm}$ displayed little visual zonation and appeared to be composed largely of silt and sand, presumably of mixed eolian and colluvial origin. Channel samples were collected at each discernible stratum in each profile.

Analytical results for 24 metals are given in table 2 . Trace-metal variation down profiles 1 and 3 is generally lacking in trends, but boron, chromium, cobalt, copper, lithium, mercury, molybdenum, nickel, scandium, vanadium, and ytterbium exhibit slight increases in concentrations downward in profile 2 . These increases reflect compositional differences between parent (bedrock) and overlying soil. Also, the basal stratum sampled in profile 1 is distinctly high in many metals and reflects the compositional contrast between the basal shale layer and the overlying sandier materials.

A comparison of the data in table 2 to the ranges of concentration in soil in table 1 indicates that vertical variation in soils of the Powder River Basin is, in general, distinctly less than that expected from place to place over the surface of the basin. They also indicate that turning over of the near-surface layers by strip mining or other activity, at least in areas with profiles like those sampled here, should not change to a great extent the total trace-metal content at the ground surface.

\section{Variation near a potential point source}

A third part of the reconnaissance study consisted of collecting a small set of sagebrush and soil samples at geometrically increasing distances away from a potential point source of metal pollution, the Dave Johnston coal-fired electric generating plant on the southern edge of the Powder River Basin. For this study, samples were collected at distances (approximate) of 0.8 , $2.6,6.6,13.5,26.4$, and $53.8 \mathrm{~km}$ eastward from the generating plant. The sampling localities are shown in figure 1. At each locality, two sites separated by about $300 \mathrm{~m}$ were sampled in a manner identical to that used in the basinwide study-a sagebrush (Artemisia tridentata); a surface $(0-2.5 \mathrm{~cm})$ soil, and a subsurface $(15-20 \mathrm{~cm})$ soil.

The analytical results of this study are listed in table 3 and an evaluation is given under "Powerplant study" in table 1 . The relation of metal concentration to distance from the powerplant was examined by regression analysis. $S^{2}{ }_{\log } D$ estimates that part of the total logarithmic variance measured along the traverse which can be described in terms of distance from the powerplant. The percent of total variation represented by $S^{2} \log D$ is also given. The regression parameters $a$ and $\hat{b}$ are coefficients of the regression equation:

$$
\log X=a+b(\widehat{\log D})
$$

where $\log X$ is an estimate of the logarithmic concentration of a trace metal and $\log D$ is the logarithm of the distance in kilometres from the plant.

It seems reasonable to require that any effects of trace-metal pollution should show up as a decrease in concentration with increasing distance from the plant; that is, the coefficient $\hat{b}$ in equation 1 should be nega- 
TABLE 1.-Statistical analysis of trace metals in soils and $[*$, component of variance tested to be significantly different from zero

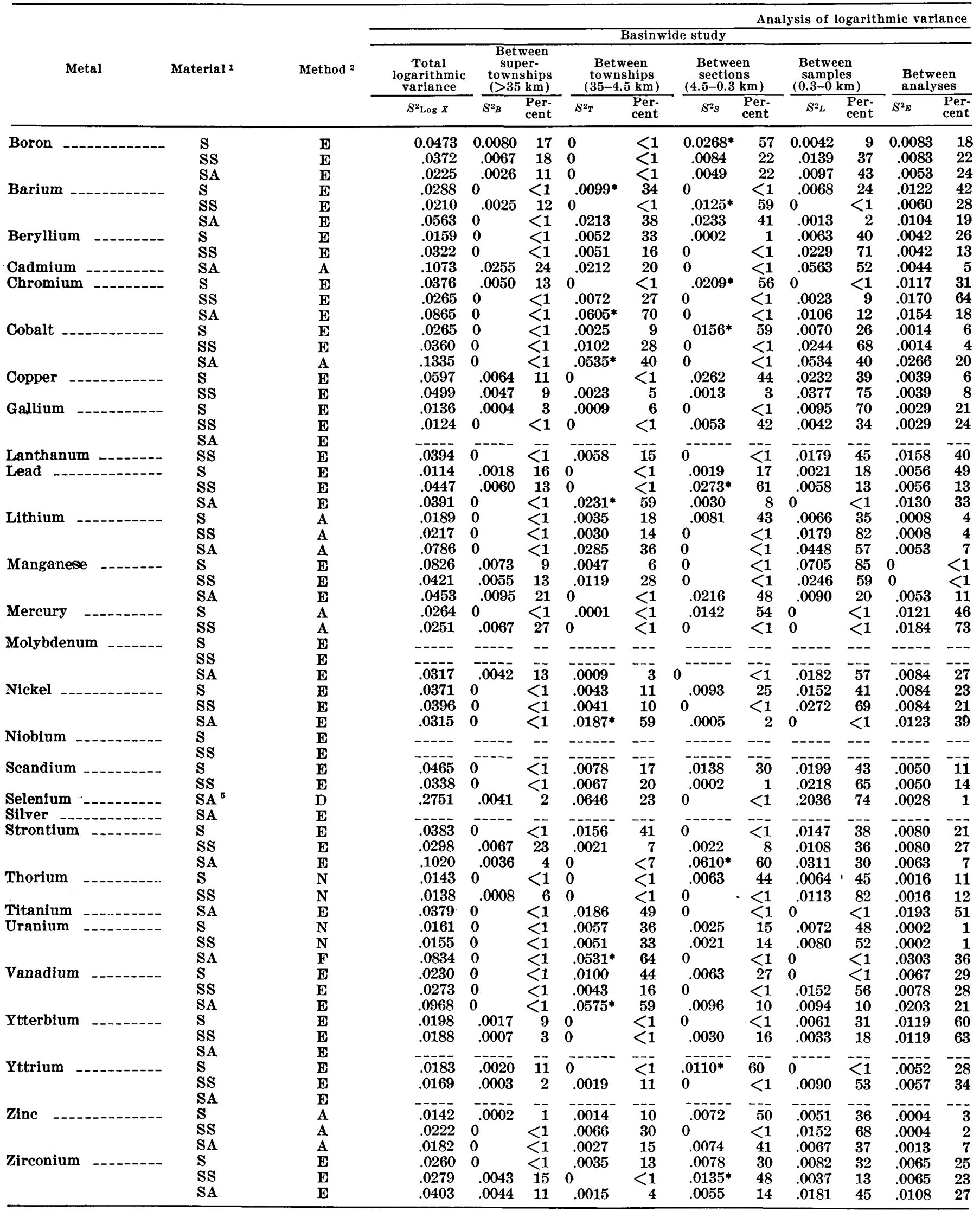

$1 \mathrm{~S}$, surface soil 0- to $2.5-\mathrm{cm}$ depth; SS. subsurface soil $15-$ to $20-\mathrm{cm}$ depth; $\mathrm{SA}$, ash of sagebrush (Artemisia tridentata)

${ }^{2} \mathrm{E}$, semiquantitative emission snectrography; $A$, atomic absorption; $\mathrm{N}$, neutron activation; $\mathrm{D}$, 2,3-diaminonapthalene extraction.

3 Coefficients of prediction equation, $\overline{\log } \bar{X}=a+b$. $\log D$

5 Determined in dry weight. 
sagebrush of the Powder River Basin, Wyoming and Montana

at the 0.05 probability level ; leaders (_.--) indicate no data available]

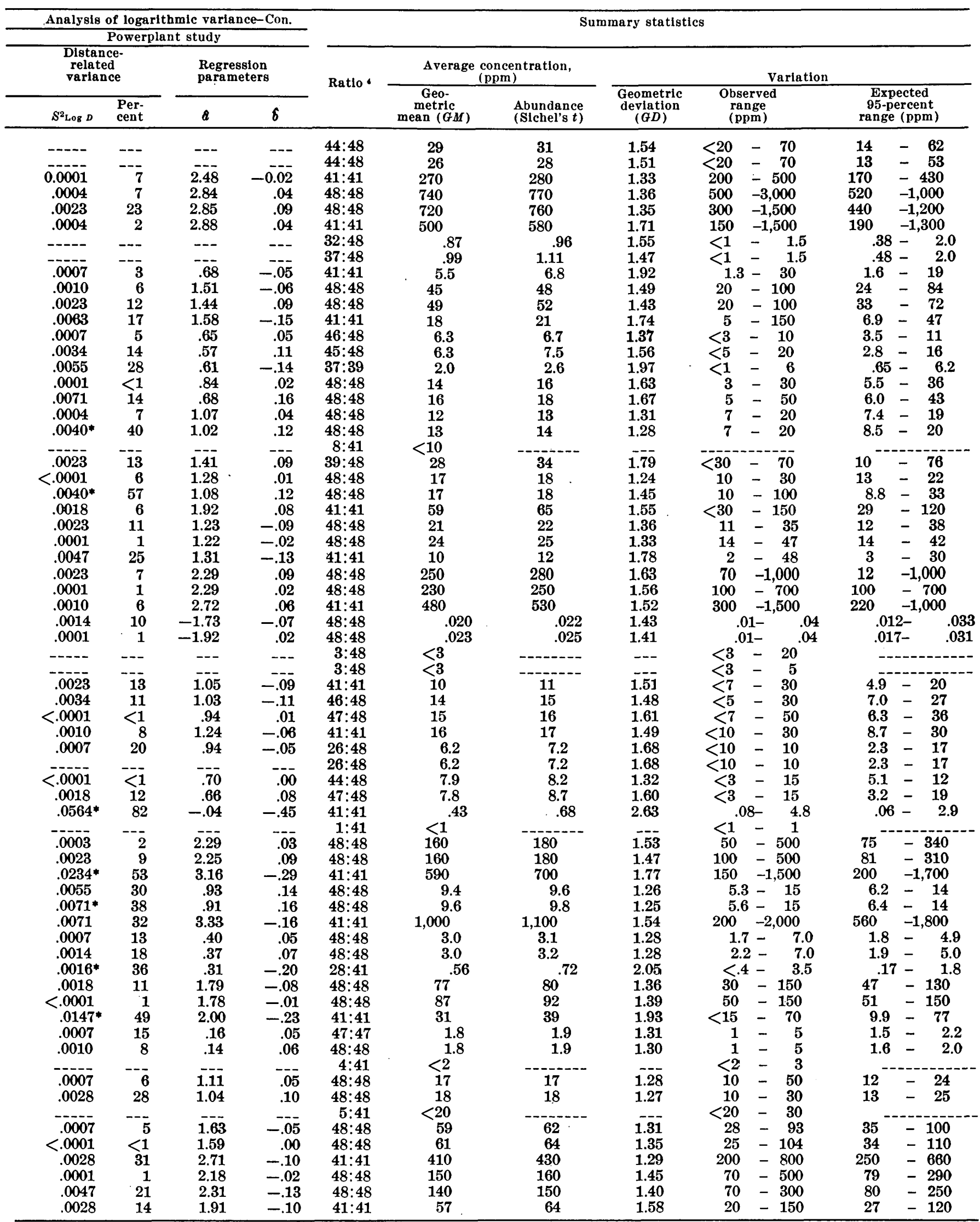




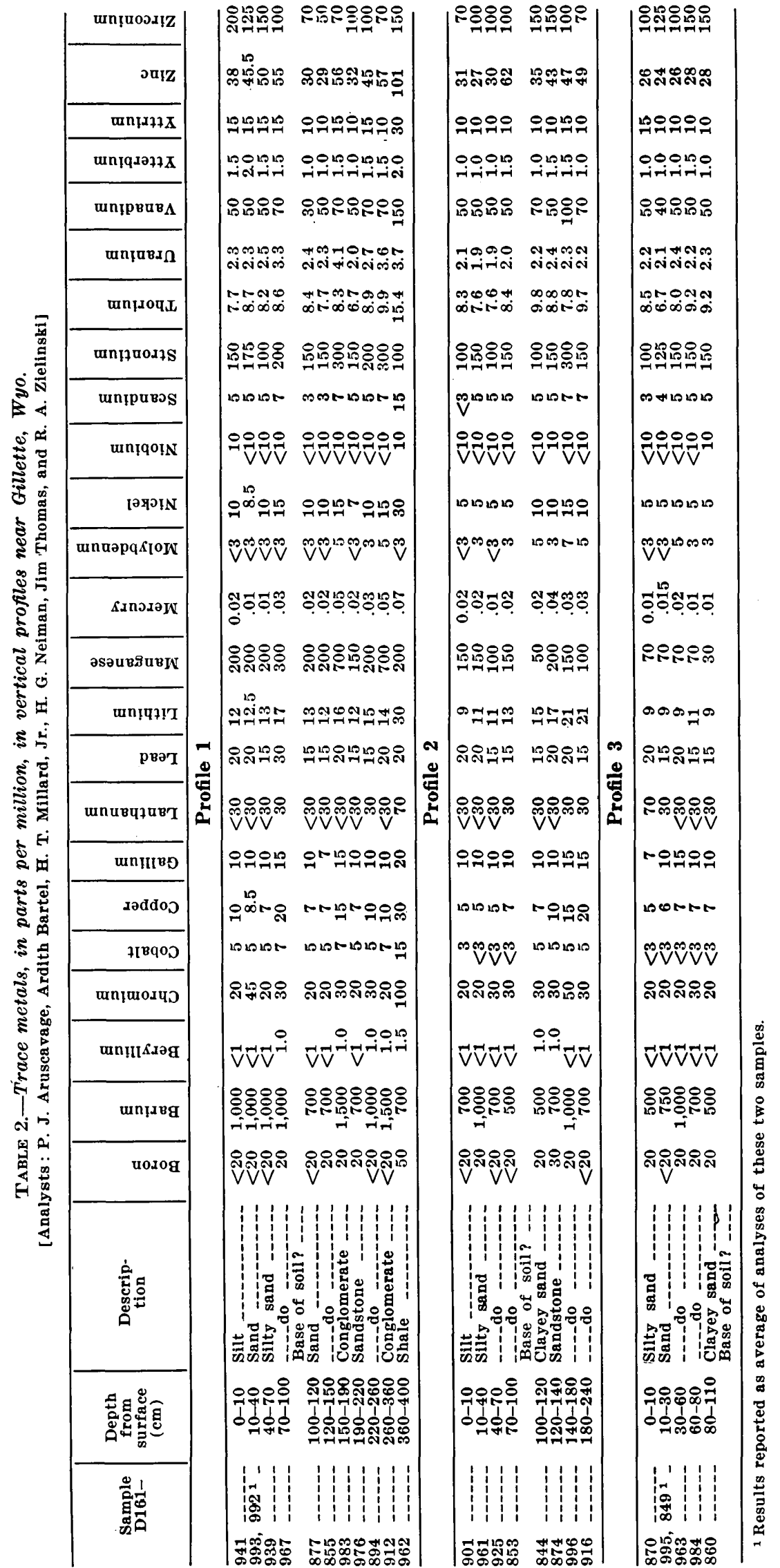



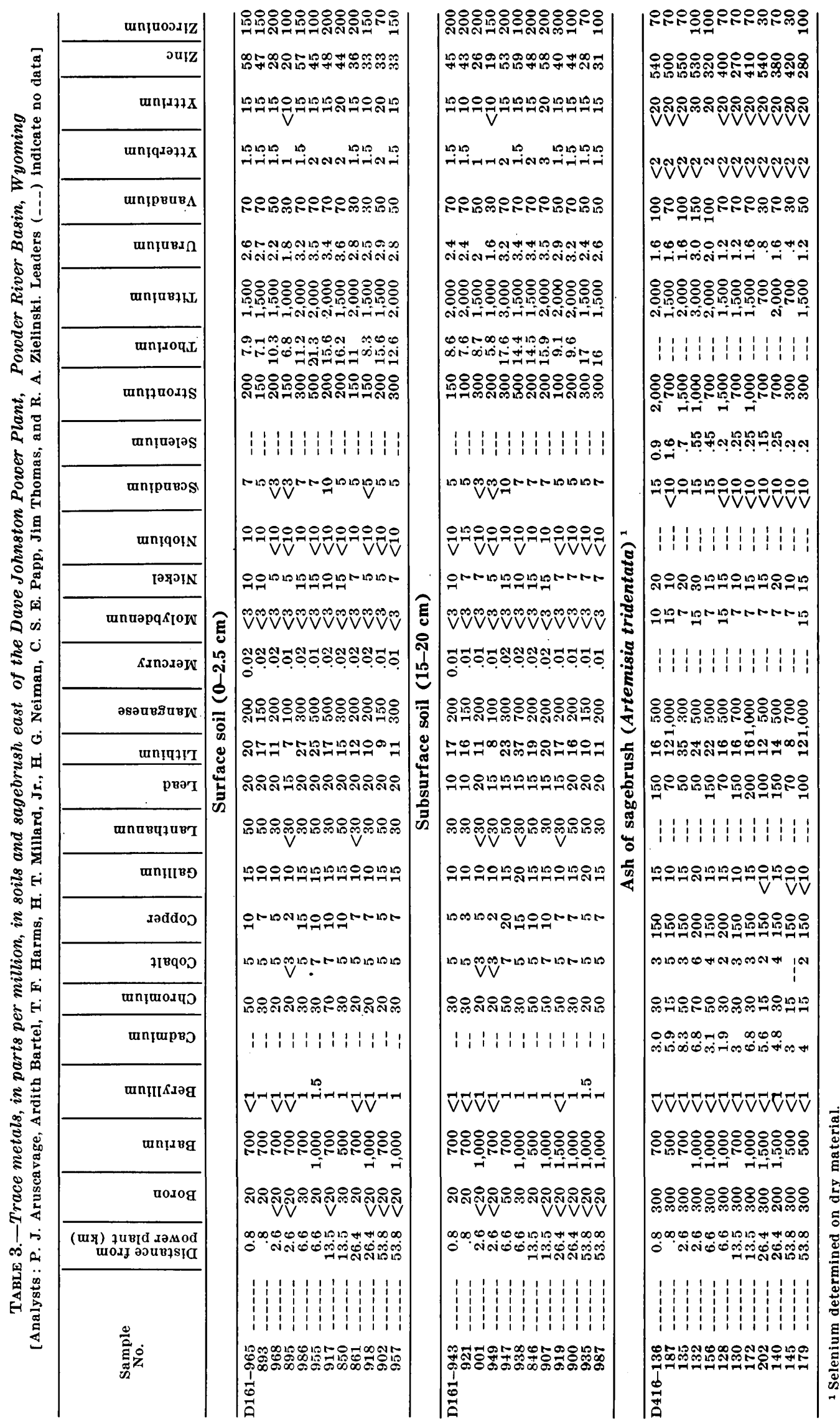
tive. Twenty-five such coefficients in table 1 are negative, indicating a decrease away from the plant, but only four-for selenium, strontium, uranium, and vanadium in sagebrush-are associated with variance components significantly different from zero at the 0.05 or lower probability level.

Thus, these four metals appear to be prime suspects as pollutants around this particular generating plant. Graphs of the decrease with distance for these metals are shown in figure 2. Additional suspect metals include cobalt, lithium, titanium, and zinc, all in sagebrush ash, because each exhibits a reduction in concentration with distance which is significant at the 0.05 - to 0.10 -probability level and which accounts for 25 percent or more of the total variation along the traverse. Graphs of the decrease with distance for these metals are also shown in figure 2.

\section{TRACE-METAL SUMMARIES}

The data collected in the basinwide study, because of the objective manner of collection, permit unbiased estimates of average geochemical properties for the sampled materials in the Powder River Basin. Summary statistics are given in table 1 under that heading. For each entry, the method of elemental analysis, the detection ratio, and five summary parameters are listed. Two average values are given-the geometric mean, $G M$, an estimate of the most probable metal concentration; and the abundance, Sichel's $t$, the estimated proportion of the material which is composed of that metal. Three expressions of variation are given-the geometric deviation, $G D$, a factor expressing the degree of total variability measured; the observed range that gives the lowest and highest concentrations measured; and the expected 95 -percent range that estimates the range that 95 percent of a suite of randomly collected samples from over the basin should exhibit.

There appears to be little compositional difference between soils collected at the surface and those taken from the subsurface (down to a $20-\mathrm{cm}$ depth). In addition, the soil averages listed in table 1 are similar to averages given for soils in the Western United States (Shacklette and others, 1971, table 3). For the most part, the upper value of the expected 95-percent range in metal variation in all materials seems to be about two to five times that of the lower value. Only rarely are these limits separated by a factor of 10 or more.

Some of the metal detected in sagebrush ash may be reflecting in part the presence of soil dust attached to the surface of the plant rather than metal actually incorporated into plant tissue. For purposes of monitoring the local environment, the source of the metal de- tected in plant ash is not critical. Nevertheless, the fact remains that many metals in plant ash are certainly being actively accumulated by the plant because concentrations detected in the ash are much too high to be accounted for in adhering soil dust. For example, there is far too much boron, lead, manganese, molybdenum, and strontium in the average ash to be attributed to adhering soil even if the assumption is made that all the ash consists of adhering soil.

\section{GEOCHEMICAL BASELINES}

This exploratory work in the near-surface geochemical environment in the Powder River Basin suggests three tentative conclusions:

1. Statistically significant geographic variation in trace-metal content of soil and sagebrush occurs almost wholly at scales less than about $35 \mathrm{~km}$, and most occurs at scales less than about $4.5 \mathrm{~km}$.

2. Vertical variation through the near-surface horizons appears to be distinctly smaller than the geographic variation, at least in the sandy interfluves of the basin.

3. Coal-fired electric generating plants may introduce detectable amounts of some trace metals into the local environment.

The last conclusion underscores the need to establish geochemical baselines in localized areas subject to energy development, but in terms of establishing baselines for the Powder River Basin as a whole, the first conclusion is paramount. A common form of a metal baseline is that of a geochemical map. But because so much of the expecterl variation in the materials studied here occurs at small geographic intervals, any map purporting to describe a reasonable amount of the variability must be based on a sample design using a relatively short sampling interval. Thus, because the basin is large, basinwide baseline maps, if they are to be at all useful, would require an extremely expensive sampling and analytical program.

The extent of the analytical requirement is indicated by examination of the percent of "mappable" or geographic variation existing at three sampling intervals. In terms of the sample design used in the basinwide study, three estimates of percentage mappable variation are:

$$
\begin{aligned}
& P_{35}=100 S^{2}{ }_{B} /\left(S^{2}{ }_{\log X}-S^{2}{ }_{E}\right), \\
& P_{4.5}=100\left(S^{2}{ }_{B}+S^{2}{ }_{T}\right) /\left(S^{2} \log X-S^{2}{ }_{E}\right), \text { and } \\
& P_{0.3}=100\left(S^{2}{ }_{B}+S^{2}{ }_{T}+S^{2}{ }_{S}\right) /\left(S^{2}{ }_{\log X}-S^{2}{ }_{E}\right),
\end{aligned}
$$

where $P_{35}, P_{4.5}$, and $P_{0.3}$ represent the percentage of geographic variation estimated to occur at scales larger than $35,4.5$, and $0.3 \mathrm{~km}$, respectively. For example, a 


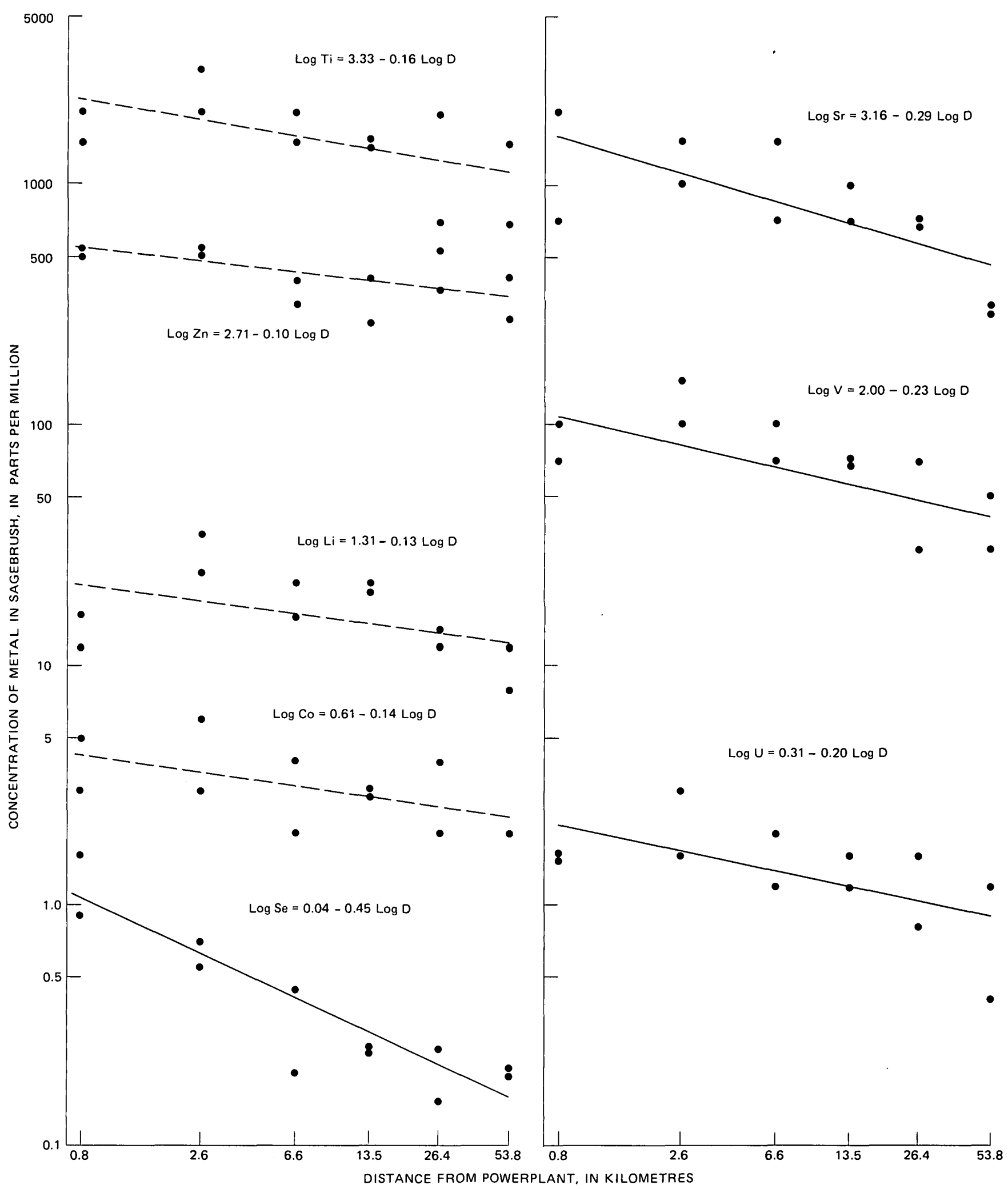

Figure 2.-Metal trends in sagebrush away from powerplant. Slopes of solid regression lines are statistically signiflcant at the 0.05 or lower probability level of dashed regression lines at the 0.05 - to 0.10 -probability levels; both define trends in concentration. Concentrations of selenium measured in dry weight; all other concentrations measured in ash weight. 
geochemical map of copper in subsurface soil based on samples taken on a $35-\mathrm{km}$ grid in the basin would describe about 10 percent of the total natural variation. A similar map based on a $4.5-\mathrm{km}$ grid would describe about 15 percent of the natural variation, and one on a $0.3-\mathrm{km}$ grid would result in only an 18-percent description.

Computations of $P_{35}, P_{4.5}$ and $P_{0.3}$ for all entries in table 1 indicate that for the most part, geochemical maps based on a sampling interval of $35 \mathrm{~km}$ (generating perhaps 50 localities for the entire basin) would rarely describe more than 10-20 percent of natural geographic variation for the materials studied. Reducing the interval to $4.5 \mathrm{~km}$ (generating about 2,600 sampling localities) would increase this proportion only slightly for many of the listed metals. The important exceptions here would be barium, strontium, and vanadium in surface soil, chromium in subsurface soil, and chromium, cobalt, lead, nickel, uranium, and vanadium in sagebrush ash, for which about half or more of the geographic variation occurs at scales equal to greater than this interval. Decreasing the sample interval to $0.3 \mathrm{~km}$ would generate over 200,000 localities in the basin. These considerations indicate the difficulties attendant on preparing geochemical maps of soil and sagebrush in the Powder River Basin.

The general lack of broadscale variation in these materials suggests a different approach to establishment of basinwide baselines. For most of the entries in table 1, samples taken at opposite ends of the basin are expected to vary little more than samples taken $35 \mathrm{~km}$ apart, and for many metals, such samples will differ little more than samples taken only $4.5 \mathrm{~km}$ apart. This suggests that intensive sampling in a relatively few limited parts of the basin could provide data on expected concentrations and expected ranges which should be applicable to all parts of the basin. For such metals, a useful baseline could consist of a few statistical parameters rather than a map whose configuration exhibits little broadscale variation. Moreover, the baseline against which unusual samples should be measured need not be a single value but, rather, could be a range of concentration. To the extent that little baseline data on trace-metal distributions currently exist for the Powder River Basin, the expected 95-percent ranges in table 1 may be taken as provisional baselines.

\section{STATISTICAL ANALYSIS AND SAMPLE DESIGN}

Because of a common tendency for trace metals in natural materials to exhibit positively skewed frequency distributions, it has become common practice to analyze and summarize trace-metal data on a logarith- mic basis. 'The estimate of the most probable concentration used in this study is the geometric mean, $G M$, which is the antilog of the mean of the logarithms of concentration. The measure of scatter about the mode used here is the geometric deviation, $G D$, which is the antilog of the standard deviation of the logarithms of concentration.

The utility of these measures is greatest if the underlying frequency distributions are, in fact, lognormal. Then, the $G M$ is the best estimate of the mode, and the estimated range of the central two-thirds of the observed distribution has a lower limit equal to $G M / G D$ and an upper limit equal to $G M \cdot G D$. The estimated range of the central 95 percent of the observed distribution has a lower limit equal to $G M /(G D)^{2}$ and an upper limit equal to $G M \cdot(G D)^{2}$. The expected 95-percent range in table 1 is based on an adjustment in the geometric deviation to counter the effects of laboratory variation, as follows:

$$
G D_{n}=\operatorname{Antilog} \sqrt{(\log G D)^{2}-S^{2}{ }_{E}}
$$

where $G D_{n}$ is the adjusted deviation to be used in computing the range.

Although the geometric mean is, in general, an adequate estimate of the most common concentration, it is, nevertheless, a biased estimate of metal abundance. In table 1, the estimate of abundance is Sichel's $t$ statistic (Miesch, 1967).

An ever-recurring problem in statistical summaries of trace-metal data arises when the metal concentration in one or more of the samples lies below the limit of analytical determination, resulting in a censored distribution. Procedures developed by Cohen (1959) are used here to compute unbiased estimates of the $G M$, $G D$, and Sichel's $t$ where concentration data are incomplete. Miesch (1967) discusses in detail the theory underlying these computation procedures. In order to estimate scale-related components of logarithmic variance in the basinwide study and the component of logarithmic variance related to distance in the powerplant study, a few samples, for which concentrations were reported as "less than" some lower limiting value, were assigned small concentration values approximately equal'to 0.7 of the limit of detection. This was done to provide a completely numeric data set for evaluation in the belief that assignment of any small value would not substantially alter the results.

The model of geochemical variation used in the basinwide study is written as:

$$
\log X_{i j k l m}=M+B_{i}+T_{i j}+S_{i j k}+L_{i j k l}+E_{i j k l m}
$$

where the logarithm of a trace-metal concentration reported on a given sample, $\log X_{i j k l m}$, is assumed to 
deviate from the true logarithmic average for that material, $M$, by the cumulative effect of five independent sources of variation. $B_{i}$ represents the effect arising at the broadest scales (between supertownships) which may be viewed as the "basinwide" effect. $T_{i j}$ represents differences observed between townships, $S_{i j k}$ represents effects observed between sections, and $L_{i j k l}$ represents effects arising at the smallest geographic scales (between localities). A fifth effect, $E_{i j k l m}$, which is always present but which is nongeographic in nature, is that due to laboratory procedure or analytical error. This effect was evaluated independently by analyzing duplicate splits of 15 samples each of plant and nonplant (soil and rock) material. Each of the effects in equation 6 is assumed to be a random variable with a mean of zero and an unknown variance. Estimates of these variances, denoted as $S_{B}^{2}$, $S_{T}^{2}, S_{S}^{2}, S^{2}{ }_{L}$, and $S_{E}^{2}$, respectively, may be computed using procedures given in Krumbein and Slack (1956), and their sum represents the total observed logarithmic variance in the basinwide study, as follows:

$$
S^{2}{ }_{\log X}=S^{2}{ }_{B}+S^{2}{ }_{T}+S^{2}{ }_{S}+S^{2}{ }_{L}+S^{2}{ }_{E} \text {. }
$$

The model of geochemical variation used in the powerplant study is:

$$
\log X_{i}=a+\hat{b}(\log D)+R_{i}
$$

where the logarithm of trace-metal concentration report on a given sample, $\log X_{i}$, is assumed to be controlled in part by the distance in kilometres, $\log D$ of the collection point from the generating plant. In this model, the total observed logarithmic variance is subdivided into two parts, one reflecting variation related to distance, $S_{\text {Log D }}^{2}$, and one reflecting all other sources of variation including laboratory variation. This latter component, representing $R_{i}$ in equation 8, was not formally estimated.

The coefficients $a$ and $b$ are estimated (as $a$ and $\hat{b}$ in equation 1) by techniques of linear regression based on the least-squares criterion (Ostle, 1954, p. 119-122). The coefficient $a$ is the logarithmic concentration of metal expected at a distance of $1 \mathrm{~km}$ from the plant, and $b$ is the slope of the trend away from the plant.

'The variance of a trend is defined by Miesch, Connor, and Eicher (1964) on the basis of an integral equation which, when evaluated for a trend of the form in equation 8 , gives:

$$
S^{2} \widehat{\log X}=S^{2} \log D=\widehat{b^{2}}\left(d_{2}-d_{1}\right)^{2} / 12 .
$$

For the powerplant study $d_{1}$ is the logarithm of $0.8 \mathrm{~km}$, $d_{2}$ is the logarithm of $53.8 \mathrm{~km}$; and $S^{2}{ }_{\log D}=0.27837 \widehat{b^{2}}$. The percentage of trace-metal variation accounted for by the regression equation 9 is computed as 100 times the square of the simple correlation between $\log X_{i}$ and $\log D$.

\section{REFERENCES CITED}

Cohen, A. C., 1959, Simplified estimators for the normal distribution when samples are singly censored or truncated : Technometries, v. 1, no. 3, p. 217-237.

Krumbein, W. C., and Slack, H. A., 1956, Statistical analysis of low-level radioactivity of Pennsylvanian black fissile shale in Illinois: Geol. Soc. America Bull., v. 67, no. 6, p. 739-762.

Küchler, A. W., 1964, Potential natural vegetation of the con. terminous United States: Am. Geog. Soc. Spec. Pub. 36, map and 116 page text.

Miesch, A. T., 1967, Methods of computation for estimating geochemical abundance: U.S. Geol. Survey Prof. Paper 574-B, 15 p.

Miesch, A. T., Connor, J. J., and Eicher, R. N., 1964, Investigation of geochemical sampling problems by computer simulation: Colorado School Mines Quart., v. 59, no. 4, p. 131-148.

Ostle, Bernard, 1954, Statistics in research: Ames, Iowa State College Press, 487 p.

McGregor, A. A., 1972, The Powder River Basin, in Mallory, W. W., ed., Geologic atlas of the Rocky Mountain region: Denver, Rocky Mtn. Assoc. Geologists, 331 p.

Shacklette, H. T., Hamilton, J. C., Boerngen, J. G., and Bowles, J. M., 1971, Elemental composition of surficial materials in the conterminous United States: U.S. Geol. Sùrvey Prof. Paper 574-D, 71 p.

U.S. Geological Survey, 1970, The national atlas of the United States of America: Washington, D.C., 417 p. 


\title{
THE SOURCE OF HYDROTHERMAL SOLUTIONS AT PUERTO MAUNABO AND ITS BEARING ON THE BASE-METAL-POTASSIUM FELDSPAR ASSOCIATION IN PUERTO RICO
}

\author{
By M. H. PEASE, Jr., Boston, Mass.
}

\begin{abstract}
A quartz oligoclase porphyry exposed near Puerto Maunabo may provide evidence to further our understanding of the base-metal-potassium feldspar association known to occur in many of the porphyry-type copper deposits of Puerto Rico. The porphyry appears to be a magmatic differentiate on the border of the San Lorenzo batholith that may represent a source of mineralizing hydrothermal solutions. The porphyry intrudes an albitized quartz diorite border phase of the batholith that contains large roof pendants of metavolcanic rock. These roof pendants are mostly metamorphosed to greenschist metamorphic facies, but in the vicinity of Puerto Maunabo south of the porphyry, they reach amphibolite metamorphic facies; north of the porphyry, similar xenolithic lenses of metavolcanic rock appear to have been converted entirely to an oligoclase quartz felsite. The layered albitized quartz felsite has the same composition and texture as irregular veinlets in the albitized quartz diorite and as the groundmass in the porphyry. The $\mathrm{K}^{+}$ions and basic ions of $\mathrm{Fe}^{+2}, \mathrm{Cu}^{+2}, \mathrm{Mg}^{+2}$ apparently were mobilized during final magmatic crystallization and then escaped as hydrothermal solutions that followed open conduits within a zone of structural weakness which also permitted the emplacement of the porphyry. The volcanic rock of Cerro Piedra Hueca, in contact with the albitized quartz diorite, and generally along strike west of the porphyry, has been altered to a quartz sericite rock entirely devoid of mafic silicates. This is the southeasternmost exposure of hydrothermally altered volcanic rock in the regional zone of northwest-trending faults that contains the principal porphyry-type copper deposits of Puerto Rico. The texture, mineralogy, and geologic environment of the porphyry at Puerto Maunabo are similar to those of the ore-bearing porphyries but differ in one important aspect. Most ore-bearing porphyries contain hydrothermal potassium feldspar and reddish-brown biotite intimately associated with the base-metal sulfides. In the porphyry of Puerto Maunabo, potassium feldspar is conspicuously absent, and only a trace of biotite is present; the only sulfide present is pyrite. The physical and chemical environment required to precipitate $\mathrm{K}^{+}$ions, either as potassium feldspar or biotite, apparently is very similar to that required to precipitate base-metal sulfides. At Puerto Maunabo, these conditions evidently did not prevail, and potassium and the base metals may have been carried in solution to a more favorable environment.
\end{abstract}

The San Lorenzo batholith is exposed in southeastern Puerto Rico (fig. 1), and the somewhat smaller Utuado batholith is exposed about $75 \mathrm{~km}$ westward in westcentral Puerto Rico. Between these two intrusive bodies and bordered on the north and south by extensive fault zones is an area underlain chiefly by Cretaceous volcanic rocks that have been moderately folded, greatly shattered, penetrated by many small granitic stocks and dikes, and locally completely altered by the action of hydrothermal solutions.

The metallogenic map of Puerto Rico (Cox and Briggs, 1973) shows that sulfide mineralization is common in Puerto Rico and that the largest base-metal deposits have been found along the southern border of the Utuado batholith. Geologic relations that may shed some light on the source of hydrothermal solutions that transport base metals have been observed in the Punta Tuna quadrangle in the southernmost exposures of the San Lorenzo batholith.

A narrow band of quartz oligoclase porphyry is exposed in a small group of hills near the village of Puerto Maunabo (fig. 2) in the southeast corner of Puerto Rico. The porphyry appears to be a late magmatic differentiate of the San Lorenzo batholith and may represent a source of mineralizing hydrothermal solutions. It occurs within an albitized quartz diorite

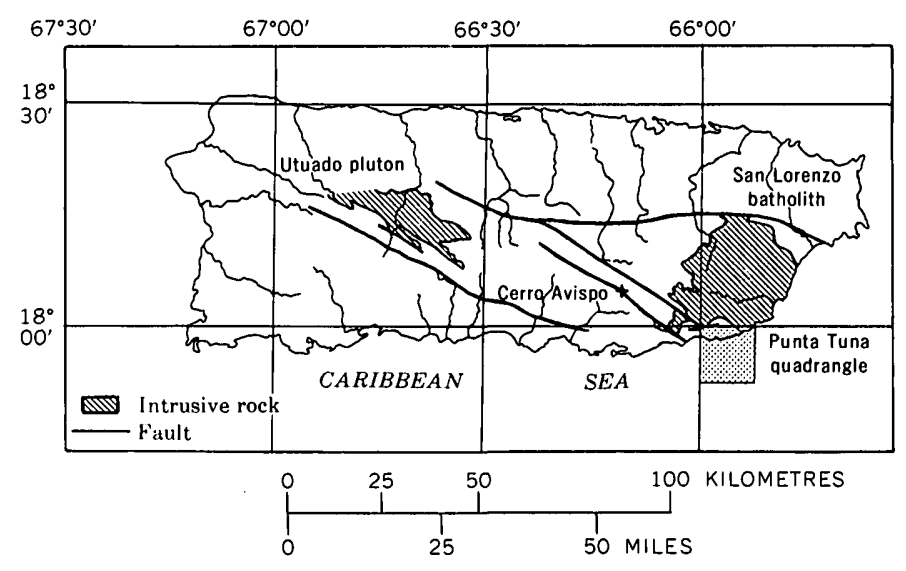

Figure 1.-Index map of Puerto Rico. 


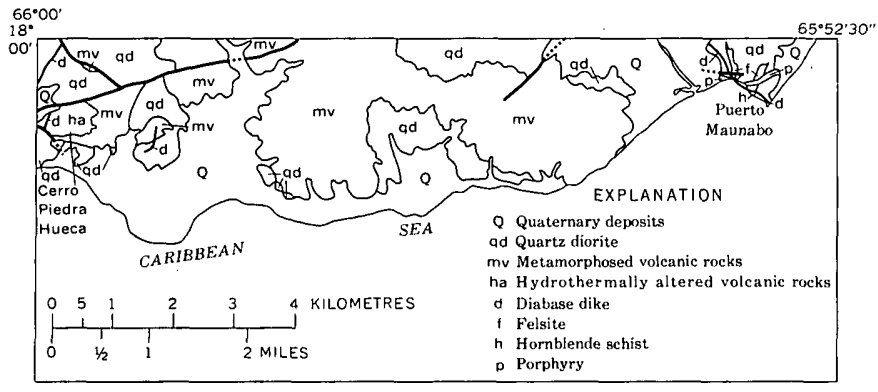

Figure 2.-Simplified geologic map of the Punta Tuna quadrangle, Puerto Rico.

body on the border of the batholith and has been hydrothermally altered. The albitized quartz diorite which shows evidence of deuteric alteration also is in contact with hydrothermally altered volcanic rock. The texture, mineralogy, and geologic environment of the porphyry are similar in many respects to those of intrusive porphyries associated with base-metal deposits in west-central Puerto Rico.

The age of the porphyry of Puerto Maunabo is not known, but if it is the same as the porphyries associated with base-metal deposits, as much as 20 m.y. may have elapsed, according to D. P. Cox (written commun., 1974), between emplacement of the San Lorenzo batholith and final emplacement of the porphyry.

\section{GEOLOGIC SETING}

The San Lorenzo batholith of Late Cretaceous age is a crudely circular plutonic complex about $25 \mathrm{~km}$ in diameter. The southern part of the batholith includes the Yabucoa and Punta Tuna quadrangles (C. L. Rogers, M. H. Pease, Jr., C. M. Cram, and M. S. Tischler, unpub. data, 1976). The Yabucoa quadrangle is underlain mostly by granitic-textured rock intermediate in composition between hornblende-biotite quartz diorite and biotite-hornblende quartz monzonite. The Punta Tuna quadrangle is underlain mostly by albitized quartz diorite having extensive roof pendants of metamorphosed volcanic rock. The northern boundary of the albitized quartz diorite appears to be transitional and is covered by alluvium and colluvium at the southern border of the Yabucoa quadrangle.

Most of the metavolcanic rocks are uniformly dark greenish gray and in the epidote greenschist facies of metamorphism. They commonly retain faint relic textures and structures that attest to their origin as interstratified lava, tuff, and breccia. At Cerro Piedra Hueca, near the western edge of the quadrangle, an area of volcanic rock has been hydrothermally altered to a very light gray rock composed chiefly of finely divided quartz and sericite.

The quartz oligoclase porphyry crops out in a relatively narrow arcuate band that passes through Puerto Maunabo (fig. 3.). It is not a true porphyry; evenly distributed clots, as much as $30 \mathrm{~mm}$ in diameter, of quartz and oligoclase phenocrysts give to this rock the apparent coarse texture of a porphyry. The southern contact of the porphyry is defined by an abrupt increase of mafic silicates in the albitized quartz diorite; the northern contact is gradational, but an indefinite contact was delineated in the field, where pyrite is no longer present and the porphyritic texture is no longer conspicuous.

A section of stratified tuff and lava exposed in sea cliffs at Puerto Maunabo has been metamorphosed to dark-greenish-gray hornblende schist. Relic primary phenocrysts are preserved in the metalavas and thinly layered stratification containing graded bedding is preserved in the metatuffs. This section is about $85 \mathrm{~m}$ wide; it trends northward and terminates abruptly at the southern border of the porphyry. Lenses of paleyellowish-brown layered felsite are exposed in two areas on the north side of the porphyry. One area is nearly on strike: with the hornblende schist; the other is about $300 \mathrm{~m}$. west. Layering within the eastern lenses conforms: generally to the attitude of relic bedding within the hornblende schist. In the second area of felsite, the-layering trends in a north-northwesterly direction, and associated with lenses of felsite in this tongue are blocks of float and a few possible outcrops of darkcolored hornblende schist possibly interlayered with the felsite. The outlines of these felsite lenses are indistinct because they interfinger with albitic quartz diorite of similar color and composition. The layered structure and areal distribution of these felsite lenses suggest that they too represent bands of metamorphosed volcanic rocks, probably stratified tuffs.

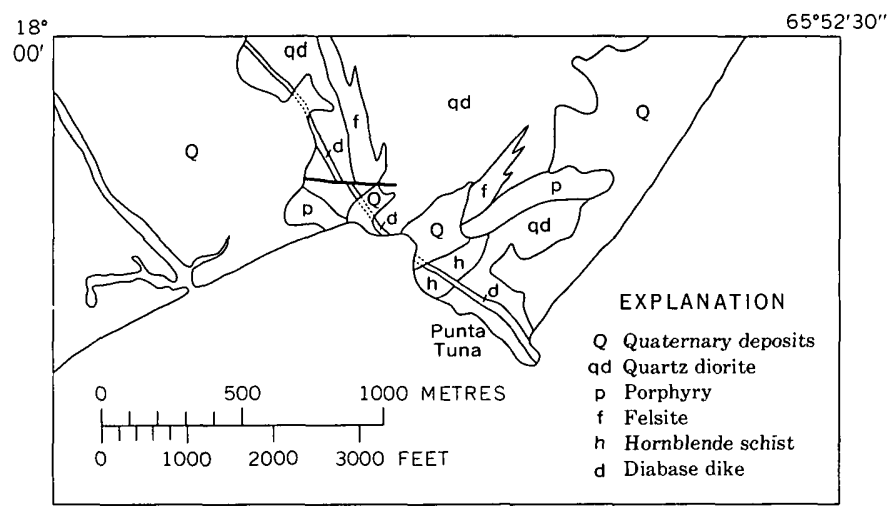

Figure 3.-Geologic map of the Puerto Maunabo area, Puerto Rico. 
A medium-gray, commonly porphyritic, diabase dike forms the crest of the sea cliff at Punta Tuna; it transects the hornblende schist lens and the band of quartz-oligoclase porphyry and extends northwestward, where it is buried by alluvial deposits. This dike is about $20 \mathrm{~m}$ wide at Punta Tuna and thins northwestward ; it is offset by faults of small displacement. Similar linear dikes also offset by minor faults intrude the southern border of the batholith at several localities.

\section{PETROGRAPHY}

Quartz oligoclase porphyry.-The quartz oligoclase porphyry is a light-gray siliceous rock containing almost no mafic silicates. Clusters of quartz and oligoclase phenocrysts are evenly distributed in a finegrained matrix of quartz and oligoclase containing wisps of reddish-brown biotite and rare clinozoisite. Fine to coarse cubic pyrite amounts to as much as 10 percent of the rock.

The two distinct grain sizes in the quartz-oligoclase porphyry are evidence of alteration and partial replacement. The coarse constituents have been partly resorbed by later interstitial material. Turbid oligoclase crystals are deeply embayed and contain secondary inclusions of quartz and clear oligoclase; many of the large quartz grains are corroded, but others appear to have been enlarged by accretion of secondary quartz to form the phenocrysts that characterize hand specimens.

Albitized quartz diorite.-The albitized quartz diorite is variable in texture and composition, but in general is a medium-grained holocrystalline rock composed chiefly of median oligoclase, An-20, and quartz, and having interstitial subhedral hornblende and biotite. Oligoclase is turbid brown and altered; it commonly shows the relic twinning of a more calcic plagioclase. It locally forms myrmekitic intergrowths with quartz. No potassium feldspar remains in the rock, if it was ever present. Coarse anhedral crystals of quartz having irregular extinction compose as much as 50 percent of some specimens; fine-grained secondary quartz also is found in microveins and interstitially with albite. Most hornblende is partly or entirely altered to granular aggregates of biotite, chlorite, epidote, magnetite, and sphene. Much of the biotite, however, appears to be original and is partly replaced by clinozoisite and chlorite minerals.

Plutonic rocks just north of the porphyry are intermediate in the transition from albitized quartz diorite to porphyry, although they have not been mapped as a separate unit. Fine-grained interstitial quartz-oligoclase aggregate, identical with the fine-grained facies of the porphyry, occurs in irregular clots and veinlets in amounts less than 15 percent. Myrmekitic intergrowths of quartz and sodic oligoclase occur in large unevenly distributed patches. Mafic constituents, which consist of olive-brown biotite in fine aggregate clots associated with minor amounts of penninite, epidote, and clinozoisite, amount to less than 5 percent of the rock. Primary hornblende is rare or absent, and finely divided magnetite is ubiquitous. This rock evidently grades northward into typical albitic quartz diorite, but the transition cannot be observed, as the exposures are surrounded by a broad alluvial valley. Albitic quartz diorite exposed south of the porphyry shows no such transition and has the typical texture and composition of that exposed farther to the west and north.

Hornblende schist.-The hornblende schist exposed south of the porphyry consists of an intergranular mosaic of sodic andesine and quartz, having stubby subiounded grains of hornblende occurring in clusters and as discrete crystals. Probable pseudomorphs of pyroxene phenocrysts are represented by clusters of hornblende showing poorly defined crystal outlines bordered by magnetite dust. Relic plagioclase phenocrysts have been so nearly resorbed that, although their optical continuity is still apparent, their crystal outlines are obscure. Bedding in the tuffs is marked by light and dark mineral segregation and by abrupt and, in part; gradational changes in grain size parallel to bedding planes.

Felsite.-The microscopic texture of the felsite north of the porphyry is much like the fine-grained facies of the porphyry. It is a granoblastic mosaic of quartz and sodic oligoclase containing many patches of myrmekite. Sheaflike clusters of biotite compose about 2 percent of the rock, and magnetite is present. The primary stratification clearly apparent in hand specimen is almost entirely obscured on a microscopic scale because of recrystallization to grain-size diameters greater than primary bedding thickness.

Hydrothermally altered volcanic rock.-The hydrothermally altered volcanic rock exposed at Cerro Piedra Hueca is composed almost entirely of quartz and sericite in a ratio of about $3: 1$. Clinozoisite occurs in granular patches, and pyrite is present. In weathered outcrops, the rock is perforated with irregular-shaped pores amounting to about 20 percent of the rock, and most pores are lined with a thin rim of dark-reddishbrown hematite, probably after sulfides.

Diabase dikes.-The diabase dikes have a typical diabasic texture, although masked by deuteric alteration. Phenocrysts composing as much as 40 percent of the rock consist of strongly zoned intermediate plagio- 
clase, An 40-60, which is sericitized and contains inclusions and veinlets of albite and hornblende. The hornblende is pseudomorphic after pyroxene and is partly altered to penninite, clinozoisite, and epidote. Relic pyroxene is rare. The groundmass consists of interlocking grains of quartz and sodic plagioclase having wisps and clots of hornblende, chlorite, clinozoisite, and, rarely, calcite.

\section{MAGMATIC DIFFERENTIATION AND FORMATION OF HYDROTHERMAL SOLUTIONS}

Exposures in the Punta Tuna quadrangle appear to demonstrate progressive stages in the formation of hydrothermal solutions from residual magmatic liquids emanating from late-crystallizing magma on the borders or near the top of the San Lorenzo batholith. The albitized quartz diorite appears to be the product of a residual melt derived from a parent dioritic to granodioritic magma by fractional crystallization in the presence of a water-rich vapor phase. By this process, $\mathrm{K}^{+}$ions were entirely removed, $\mathrm{Ca}^{+2}, \mathrm{Mg}^{+2}$, and $\mathrm{Fe}^{+2}$ ions were depleted, and the breakdown of primary silicates resulted in the formation of hydrous silicates accompanied by an increase in the relative amount of free quartz.

The oligoclase-quartz porphyry represents a concentration of later crystallizing volatile-rich magma further depleted in basic constituents. A mush of coarse crystals having interstitial fluid magma evidently was squeezed upward as an east-trending dike along a fault or fracture. In the process of cooling and final crystallization, many of the early-formed coarse crystals of the mush were resorbed by reaction with the residual magma. Along the northein border of the porphyry, this residual magma penetrated for a considerable distance from the contact fractures and interstices in essentially crystalline albitized quartz diorite. Xenolithic lenses of metavolcanic rock also were almost entirely converted to oligoclase quartz felsite. Conceivably, these metavolcanic rocks had originally been basaltic in composition.

Evidence that suggests a basic volcanic origin for the felsite may be summarized as follows:

1. The felsite exposed north of the porphyry is distinguished from the enclosing albitized quartz diorite by a conspicuous layering very similar to that in the hornblende schist south of the porphyry.

2. The composition and microscopic texture of the felsite, however, is identical with the fine-grained clots and veinlets in the surrounding altered albitized quartz diorite just north of the porphyry.
3. Lenses of the eastern area of the felsite are nearly on strike with the hornblende schist to the south, and the layering is essentially parallel to the layering in the schist.

4. No felsite was observed south of the porphyry, but a few slabs of green hornblende schist float, perhaps preserved remnants, are associated with the western felsite area north of the porphyry.

During final crystallization of the porphyry the remaining water-rich vapor phase escaped, probably as hydrothermal solutions via fractures in the overlying volcanic rock, carrying released basic ions of $\mathrm{Fe}^{+2}$, $\mathrm{Ca}^{+2}$, and $\mathrm{Mg}^{+2}$, and previously mobilized $\mathrm{K}^{+}$ions. Evidence in the porphyry of the former presence of volatiles carrying these ions is indicated by the occurrence of ubiquitous pyrite, myrmekite, rare muscovite, and traces of reddish-brown biotite and clinozoisite.

Lateral and vertical distribution of these hydrothermal solutions appears to have been confined to open conduits within the zone of structural weakness that permitted emplacement of the porphyry. The hydrothermally altered quartz-sericite rock exposed at Cerro Piedra Hueca is roughly in line with this zone of structural weakness. The solutions that altered the porphyry at Punta Maunabo also may have altered the volcanic rock at Cerro Piedra Hueca.

This altered volcanic rock is at the eastern terminus of a belt of disconnected outcrops of hydrothermally altered volcanic rock (shown on the metallogenic map by Cox and Briggs, 1973), that extends northwestward toward Cerro Avispa (fig. 1). Iron sulfides have been found at several localities within this belt, and a potential ore deposit of quartz veins containing traces of gold and silver as well as minor sulfides is exposed in the Cerro Avispa area. These exposures of hydrothermally altered rock almost certainly are alined along a zone of faulting, not shown on the metallogenic map, that parallels the principal trend of mineralization in Puerto Rico.

The hydrothermal alteration appears to be older than the diabase dike that cuts the porphyry because the dike shows no evidence of alteration that cannot be ascribed to deuteric alteration.

\section{ANALOGY TO ENVIRONMENT OF BASE-METAL DEPOSITION IN PUERTO RICO}

Some of the geologic characteristics of copper-mineralized areas in Puerto Rico were presented at the Third Caribbean Geological Conference (Pease, 1966). This paper concluded that most deposits of economic interest are of the porphyry copper type. Among the essential features of this type of deposit in Puerto 
Rico are irregularly shaped dikes of porphyritic quartz diorite within and alined roughly parallel to one or another of the major west-northwest- to northwest-trending shear zones of the island. Where not hydrothermally altered, this porphyritic intrusive rock consists of subhedral phenocrysts of albitized plagioclase, quartz, and olive-brown hornblende and biotite in a microcrystalline groundmass composed chiefly of albite, granular quartz, and chlorite. Plagioclase phenocrysts and mafic minerals both show evidence of deuteric alteration.

In mineralized areas, however, both the intrusive and the volcanic country rock are intensely fractured and hydrothermally altered. They are strongly silicified and sericitized and the primary silicates have been essentially destroyed. Quartz-sulfide veins and calcite veins fill the fractures. Some quartz veins, particularly within or closely associated with the intrusive rock, contain copper-bearing sulfides, and commonly these veins also contain adularia and magnetite. Sulfides are also disseminated throughout the highly fractured volcanic and intrusive rock, but copper sulfides appear to be concentrated along the borders of hydrothermally altered porphyritic quartz diorite. Finely divided reddish-brown biotite appears to be a hydrothermal mineral intimately associated with these copper sulfides.

The textures and composition of the quartz oligoclase porphyry at Puerto Maunabo have many of the characteristics and associations of hornblende-quartz diorite porphyry stocks associated with the porphyry copper-type mineral deposits of Puerto Rico (Cox, Lar'son and Tripp, 1973). They are highly siliceous porphyries that contain finely divided conspicuously reddish-brown hydrothermal biotite and no primary mafic silicates. The similarity is clearly apparent; the conspicuous differences are the absence of potassium feldspar and the absence of base metals at Puerto Maunabo.

The potassium feldspar, present in the San Lorenzo batholith, is not present in the albitized quartz diorite or in the quartz oligoclase porphyry. Yet the occurrence of myrmekite in the porphyry suggests that $\mathbf{K}^{+}$ ions were present in the magma and were segregated out during late-stage deuteric alteration that accompanied the release of water-rich volatiles to form hydrothermal solutions.
Most of the porphyry-copper-type ore deposits in Puerto Rico, on the other hand, contain, in veinlets, hydrothermal biotite and potassium feldspar in addition to the base metals (Cox, Larson and Tripp, 1973). Although $\mathrm{K}^{+}$ions are not necessarily required to precipitate base metals from solution, the physical and chemical environment that causes the precipitation of $\mathrm{K}^{+}$ions, either as biotite or potassium feldspar, appears to be very similar to that required for precipitation of base-metal sulfides.

\section{CONCLUSIONS}

The quartz oligoclase porphyry exposed at Puerto Maunabo appears to be a late-magmatic deuterically altered phase of the San Lorenzo batholith and the source of hydrothermal solutions that have altered volcanic rocks at Cerro Piedra Hueca. A northwest-trending zone of fractures that extends from Cerro Piedra Hueca at least as far as Cerro Avispa evidently acted as an open conduit for passage of these hydrothermal solutions.

Hydrothermally altered rock found along many other northwest- and west-northwest-trending shear zones probably was altered by similarly derived hydrothermal solutions. Where the porphyry intrusive rock is exposed in these zones, it too is hydrothermally altered and contains sulfides. If hydrothermal potassium feldspar and biotite are present in veinlets in the highly fractured porphyry and adjacent country rock, the sulficles commonly contain base metals, but base-metal sulfides do not tend to precipitate if, as at Puerto Maunabo, $\mathrm{K}^{+}$ions have been driven off prior to crystallization and hydrothermal alteration.

\section{REFERENCES CITED}

Cox, D. P., and Briggs, R. P., 1973, Metallogenic map of Puerto Rico: U.S. Geol. Survey Misc. Geol. Inv. Map I-721.

Cox, D. P., Larson, R. R., and Tripp, R. B., 1973, Hydrothermal alteration in Puerto Rican porphyry copper deposits : Econ. Geology, v. 68, no. 8, p. 1329-1334.

Pease, M. H., Jr., 1966, Some characteristics of copper mineralization in Puerto Rico, in Caribbean Geol. Conf., 3d, Kingston, Jamaica, 1962, Transactions: Jamaica Geol. Survey Pub. 95, p. 107-112. 



\title{
AGE AND TECTONIC SIGNIFICANCE OF VOLCANIC ROCKS ON ST. MATTHEW ISLAND, BERING SEA, ALASKA
}

\author{
By WILLIAM W. PATTON, Jr., MARVIN A. LANPHERE; \\ THOMAS P. MILLER, and RICHARD A. SCOTT, \\ Menlo Park, Calif.; Anchorage, Alaska, Denver, Colo.
}

\begin{abstract}
Reconnaissance investigations of the heretofore little known volcanic assemblage on St. Matthew Island provide significant information on the tectonic history of the Bering Sea shelf. St. Matthew Island is made up of approximately $500 \mathrm{~m}$ of subaerial calc-alkaline volcanic rocks ranging in composition from high-alumina basalt to rhyolite. Four $\mathbf{K}$-Ar analyses of samples from this volcanic sequence give Late Cretaceous ages of 65-77 m.y., and intercalated carbonaceous tuff layers yield Cretaceous pollen assemblages. Along the northeast coast of St. Matthew Island, the volcanic rocks are intruded by granodiorite that gives an early Tertiary K-Ar age of 61 m.y. Correlations with on-land geology in northeast Siberia and marine geophysical data from the western Bering Sea strongly suggest that St. Matthew Island represents a southeastward extension of the Okhotsk-Chukotsk belt, a Cretaceous and early Tertiary volcanic arc that borders the Pacific margin of Siberia for nearly $3,000 \mathrm{~km}$. The apparent continuation of this volcanic are along the margin of the Bering shelf at least as far east as St. Matthew Island supports suggestions by Burk and by Scholl and others that in late Mesozoic time the Pacific plate margin coincided with the present Bering shelf margin and did not shift to the Aleutian trench until the end of Cretaceous or the beginning of Tertiary time.
\end{abstract}

During the summer of 1971 the U.S. Geological Survey conducted a reconnaissance expedition to St. Matthew Island in the central Bering Sea aboard the Survey research vessel Don J. Miller II. The purpose of the expedition was to obtain basic geologic information on the age and lithologic character of the volcanic rocks on St. Matthew Island as part of a broad program of onshore and offshore investigations of the energy and mineral resources of the Bering Sea shelf. St. Matthew Island had not been mapped previously, and available geologic information was confined to brief notes from early exploratory surveys of the Bering Sea region published more than 50 yr ago (Dawson, 1894; Emerson, 1904).

St. Matthew Island together with two small neighboring islands, Hall and Pinnacle, is situated $400 \mathrm{~km}$ west of mainland Alaska on the broad continental shelf that connects Alaska and Siberia (fig. 1). Although these islands have a combined area of only $350 \mathrm{~km}^{2}$, they are important because they provide a rare subaerial exposure of the geology of the shelf and furnish new information on the tectonic history of the Bering Sea region.

This report briefly describes the geology of the island and suggests how the island fits into the tectonic framework of the Bering Sea region.

\section{DESCRIPTION OF ROCK UNITS}

St. Matthew and nearby Hall and Pinnacle Islands are made up almost entirely of an assemblage of flatlying to gently folded subaerial calc-alkaline volcanic rocks of Late Cretaceous and earliest Tertiary age

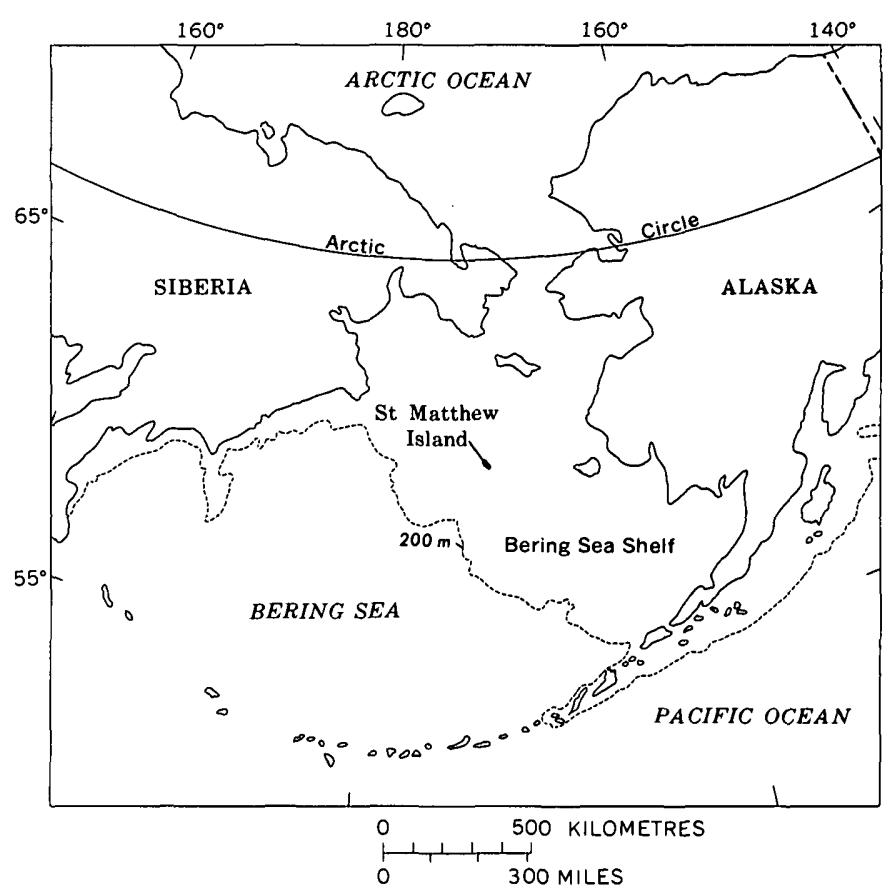

Figure 1.-Index map showing St. Matthew Island and Bering Sea shelf. Dashed line, outer margin of shelf at $200-\mathrm{m}$ contour. 
(fig. 2) (Patton and others, 1975). The exposed thickness of the volcanic sequence is at least $500 \mathrm{~m}$. Along the north coast of St. Matthew Island the volcanic rocks are intruded and thermally altered by small stocks of granodiorite of early Tertiary age. A small fault-bounded block of contorted volcanic graywacke and argillite of probable Cretaceous age occurs near the center of the island.

\section{Volcanic assemblage}

The lower part of the volcanic assemblage consists chiefly of andesite, dacite, and rhyolite tuff and breccia with minor andesitic and dacitic flows, dikes, and plugs. This predominantly pyroclastic succession underlies virtually all of of St. Matthew Island and also is exposed in a small area along the east side of Hall Island (fig. 2). Pollen, identifiable as Cretaceous in age, was collected from these rocks at two localities along the southwest coast of St. Matthew Island. No samples of the tuffs and breccias suitable for isotope dating were found on St. Matthew Island because of pervasive alteration by granodiorite intrusions. An unaltered sample of rhyolite breccia from Hall Island, however, gave mineral pair K-Ar dates of $74.1 \pm 2 \mathrm{~m} . \mathrm{y}$. and $74.4 \pm 2$ m.y. (Late Cretaceous) for biotite and hornblende, respectively. Analytical data for the K-Ar ages have been published previously (Patton and others, 1975).

The pyroclastic rocks are capped by flows of highalumina basalt and andesite that are at least $250 \mathrm{~m}$ thick at the north end of St. Matthew Island and on Hall Island. On Hall Island these flows are interlayered with andesitic tuffs and conglomerate. Potassiumargon ages of $76.8 \pm 2$ m.y. and $64.8 \pm 2$ m.y. (Cretaceous and Tertiary?) were obtained from two whole-rock samples of the flows at the north end of St. Matthew Island (Patton and others, 1975).

The youngest volcanic rocks are rhyolite and dacite welded tuffs and fine-grained hypabyssal rocks that appear to be, at least in part, cogenetic with granodiorite. These felsic volcanic rocks have not been dated isotopically but are assigned a Tertiary (probable earliest Tertiary) age on the basis of their apparent consanguinity with the granodiorite.

\section{Granodiorite}

Fine-grained leucocratic hornblende granodiorite crops out in seacliffs at several localities along the north-facing coast of St. Matthew Island (fig. 2). The total exposed area of the granodiorite is small, but the volume of these intrusive rocks may be considerably greater in the subsurface. This is suggested by the rela- tively large area of thermal alteration of the pyroclastic host rock extending well beyond the small area of exposure of the granodiorite. A greater subsurface volume is also suggested by a broad $10 \mathrm{mGal}$ positive gravity anomaly over the coastline which, according to Barnes and Estlund (1975), can be accounted for by the density contrast between a large granodiorite body at shallow depth and the less dense pyroclastic host rocks.

A potassium-argon age of $60.7 \pm 2$ m.y. (earliest Tertiary) was obtained from hornblende from a sample of the granodiorite collected on the central part of the island.

\section{Volcanic graywacke and argillite}

A puzzling section of highly deformed and thermally altered marine volcanic graywacke and argillite occurs in a small fault-bounded block in the central part of St. Matthew Island (fig. 2). These sedimentary rocks show small-soale crossbedding and convolute laminations suggesting that they are the distal facies of a turbidite. No other exposures of these rocks were found, and their age and stratigraphic relations are uncertain. The structural complexity of these rocks indicates that they probably are older than the Upper Cretaceous volcanic rocks of the island. However, the proximity of St. Matthew Island to the probable Cretaceous margin of the Bering shelf and correlations with on-land geology in northeast Siberia make it appear likely that they are Cretaceous.

\section{CHEMICAL ANALYSES AND NORMS}

The volcanic and plutonic assemblage on St. Matthew Island shows a typical calc-alkaline trend on an AFM plot of 34 representative samples (fig. 3 ). The alkalilime index for the samples is 58 and well within the calc-alkali field of Peacock (1931). The analyzed samples (Patton and others, 1975) include high-alumina basalt flows; andesite, dacite, and rhyolite tuffs, flows, and hypabyssal rocks; and granodiorite. All the samples are quartz and hypersthene normative, and some of the more silicic andesite contains sufficient excess of $\mathrm{Al}_{2} \mathrm{O}_{3}$ so that corundum appears in the norm with the consequent exclusion of diopside.

\section{LATE CRETACEOUS AND EARLIEST TERTIARY VOLCANISM AND TERRIGENOUS DEPOSITION IN THE BERING SEA}

The broad distribution of volcanism and terrigenous deposition in the Bering Sea region during Late Cretaceous and earliest Tertiary time ( $\approx 80$ to 55 m.y. ago) 


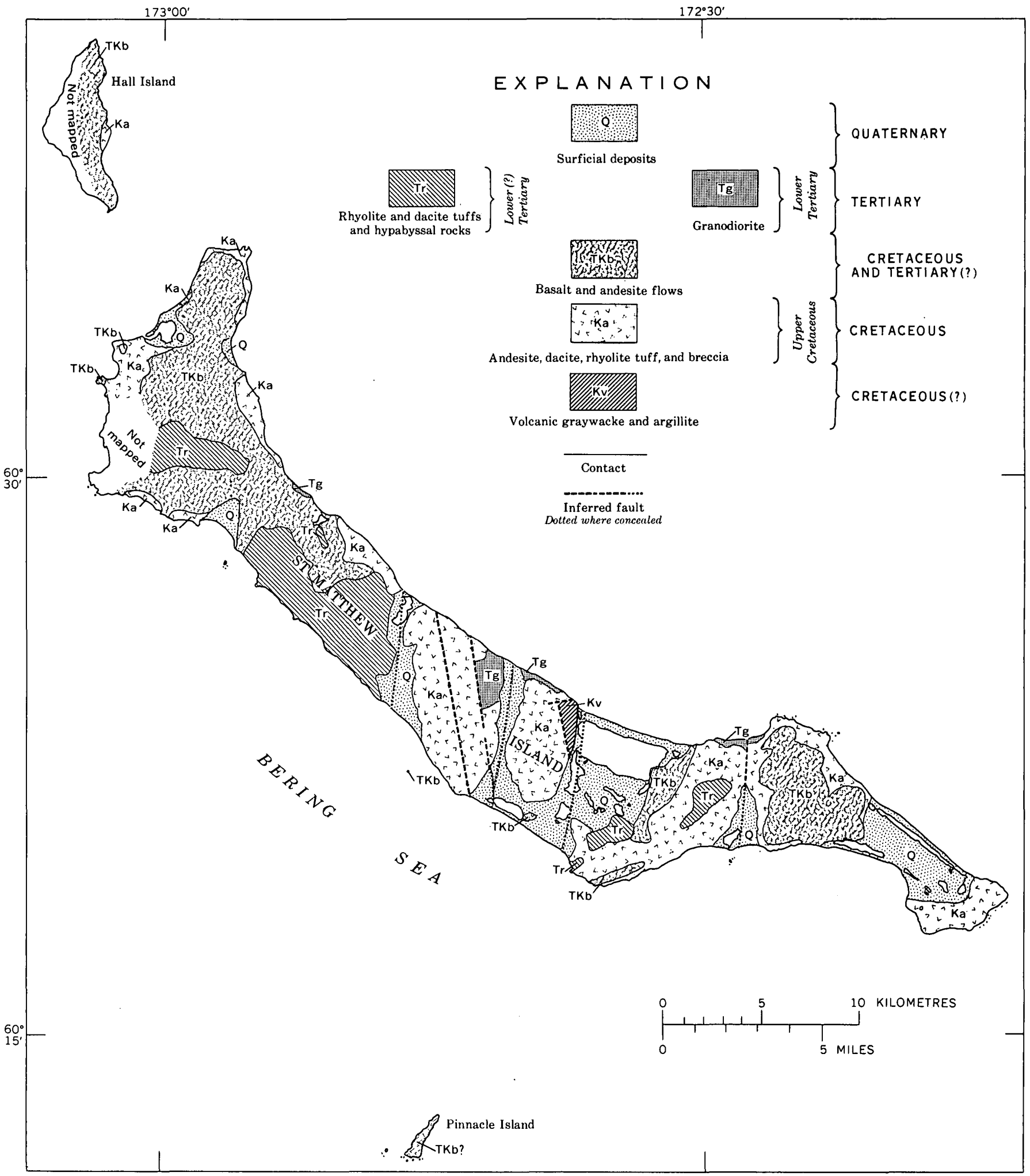

Figure 2.-Reconnaissance geologic map of St. Matthew Island. Geology from Patton, Miller, Berg, Gryc, Hoare, and Ovenshine (1975). 


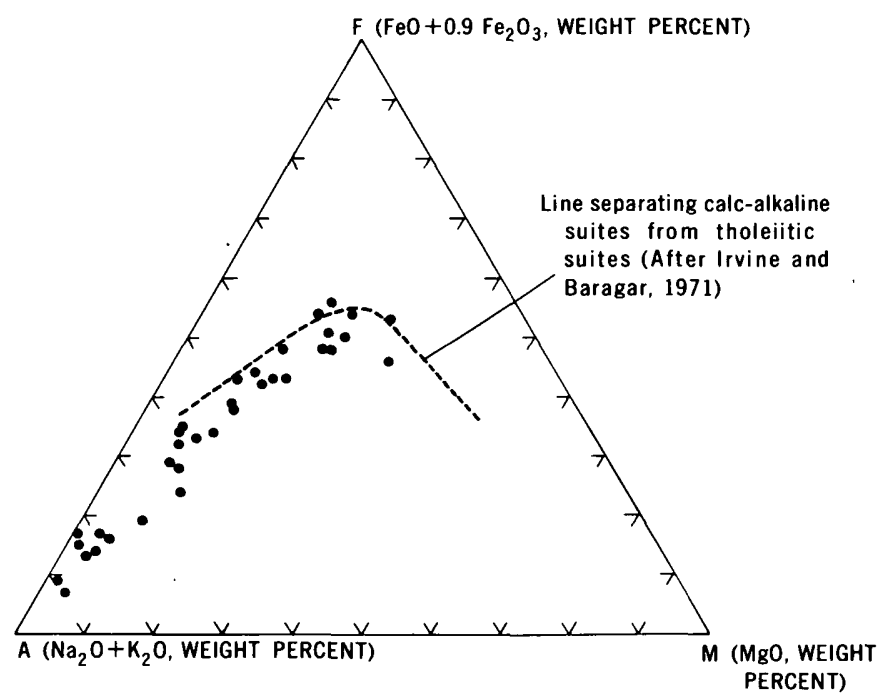

Figure 3.-AFM plot of 34 representative samples of volcanic and plutonic rocks on St. Matthew Island.

is shown in figure 4. During this time thick terrigenous sediments were being deposited along the continental margins of northeast Siberia and Alaska. At the same time volcanism occurred behind the continental margin along a relatively narrow belt in northeast Siberia and over a somewhat broader belt in western Alaska. The northern limit of large-scale volcanic and plutonic activity was the pre-Late Cretaceous miogeosynclinal Verkhoyansk-Chukotsk belt in Siberia and the Seward Peninsula-Brooks Range belt in Alaska. Between Alas$\mathrm{ka}$ and Siberia, the belt of miogeosynclinal rocks appears to bow southward through St. Lawrence Island (Patton and Tailleur, 1972).

\section{Volcanism}

In northeast Siberia volcanic and associated plutonic activity was confined largely to the Okhotsk-Chukotsk belt, a relatively narrow but continuous tectonic feature that parallels the Pacific margin in Siberia for nearly 3,000 km (Belyi, V. F., 1973; 'Tilman and others, 1969). In the vicinity of the Gulf of Anadyr, the Okhotsk belt turns abruptly to the southeast and extends along the south side of the Chukotsk Peninsula.

Recent offshore geophysical investigations and onshore geologic mapping on St. Matthew and St. Lawrence Islands suggest that the Okhotsk-Chukotsk belt continues southeasterly across the Bering shelf at least as far as St. Matthew Island (fig. 4). In the Gulf of Anadyr and on the western Bering shelf, Soviet geologists believe that they can trace the volcanic rocks of the Okhotsk-Chukotsk belt along a broad Cenozoic high from the Chukotsk Peninsula nearly to St. Matthew Island (Verba and others, 1971). On St. Law- rence Island subaerial calc-alkaline volcanic rocks similar to those on St. Matthew Island have been mapped on the western and central part of the island (Patton and Csejtey, 1971). Three K-Ar ages have been reported for the volcanic rocks on St. Lawrence Island : 62.8 and 60.5 m.y. on sanidine and hornblende, respectively, from a trachyte (Patton and Csejtey, 1971) and 62.2 m.y. on a dacite (Dalrymple and Lanphere, 1971).

The extent and distribution of volcanic rocks on the Bering shelf east of St. Matthew Island are not known. However, in western Alaska a major belt of subaerial calc-alkaline volcanic rocks can be traced for about 800 $\mathrm{km}$ northeastward from the lower Kuskokwim River valley to the Arctic Circle. Six $\mathbf{K}$-Ar ages ranging from 58 to 69 m.y. (Patton and Miller, 1973; Hoare and Condon, 1966; Hoare, unpub. data; and Patton, Lanphere, and Brosgé, unpub. data) have been obtained from these volcanic rocks. Two smaller areas of similar volcanic rocks also have been mapped in the upper Kuskokwim-Yukon region (Cass, 1959; Eakin, 1918 ), but no isotopic ages have been measured on these rocks.

In addition to the known areas of volcanism shown in figure 4 the broad region of western Alaska south and east of the Seward Peninsula-Brooks Range belt also contains many large granitic plutons, some of which may represent roots of former volcanic terranes. Only a few of these plutonic bodies have been dated isotopically, but these ages are sufficient to show that magmatism was widespread in Late Cretaceous and earliest Tertiary time. For example, in the northern Yukon-Koyukuk region along the Hogatza trend a major plutonic event has been dated at about 80 m.y. (Miller and others, 1966). An age of 79 m.y. has been measured on a large granitic pluton at Cape Romanzof in the Yukon delta (Hoare and Condon, 1968), and a similar pluton in the central Kuskokwim region has yielded an age of 65 m.y. (Hoare, unpub. data, 1975). In southern Alaska, Reed and Lanphere (1973) have documented a major intrusive phase in the AlaskaAleutian Range batholith between 58 and 83 m.y. on the basis of $70 \mathrm{~K}$-Ar mineral ages.

\section{Terrigenous deposition}

In Alaska, a belt of highly folded deep-water flysch deposits containing a sparse Maestrichtian fauna has been traced from the Chugach Mountains through Kodiak and the Shumagin Islands (Jones and Clark, 1973). At the southwest end in the Shumagin Islands, Moore (1972) found evidence that this belt did not continue southwestward along the Aleutian Arc but crossed the trend of the Alaska Pen- 


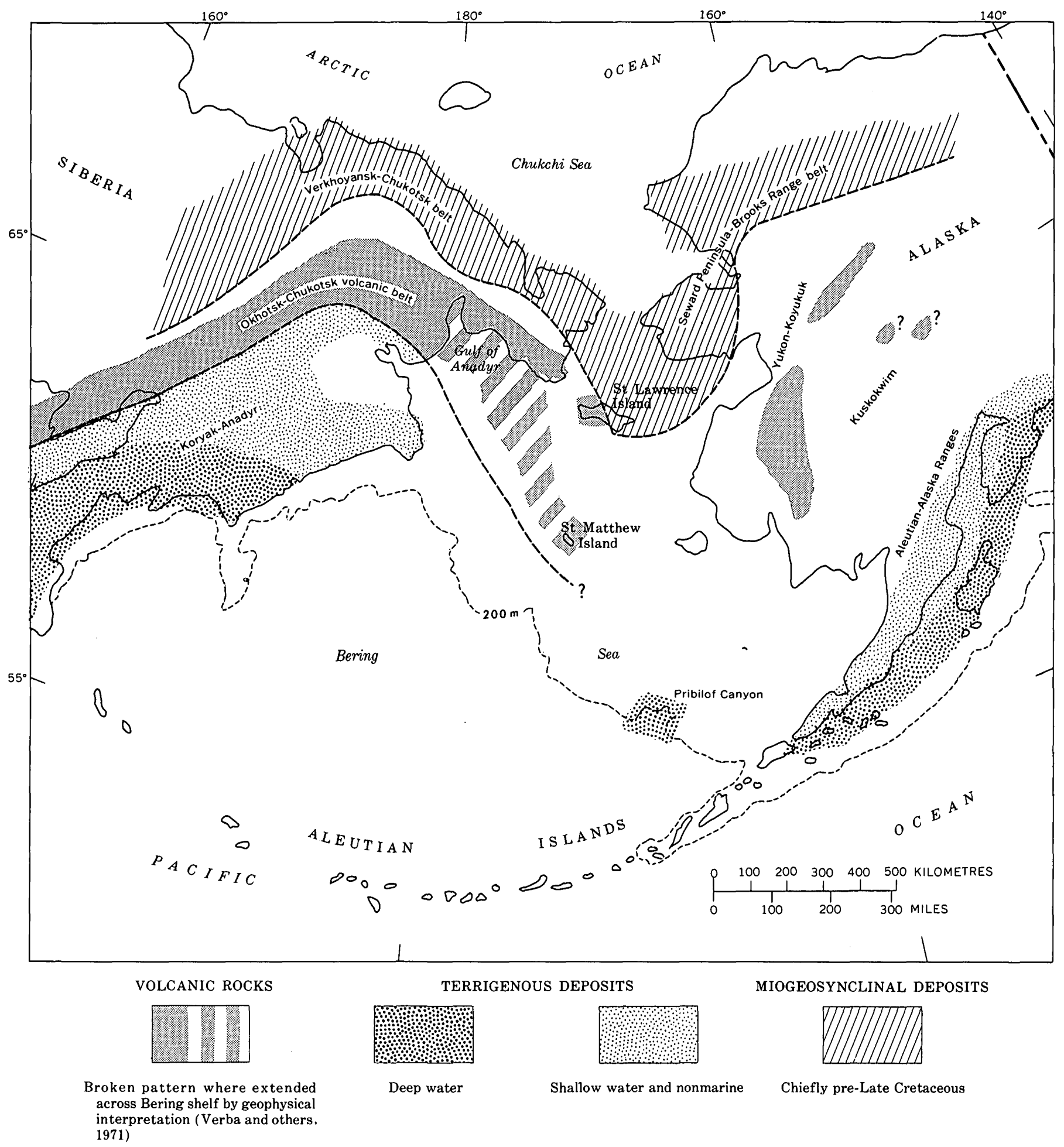

FIgURE 4.-Distribution of volcanism and terrigenous deposition in the Bering Sea region during Late Cretaceous and earliest Tertiary time ( $\approx 80$ to 55 m.y. ago). Outer margin of Bering Sea shelf at 200 -m contour shown by dashed line.

insula and extended northwestward along the margin of Bering Sea shelf. These deep-water deposits are bordered on the north by a band of fossiliferous shallowwater sedimentary deposits that stretches from the Wrangell Mountains to the lower Alaska Peninsula.
In the Koryak-Anadyr region of Siberia (fig. 4), Soviet geologists (Avdeiko, 1971; Gladenkov, 1964) also recognize an outer belt of deep-water flysch deposits with mafic volcanic rocks and an inner belt of shallow-water and nonmarine sedimentary deposits. 
Along the Bering shelf margin, acoustical profiling and dredging by Scholl, Buffington, and Marlow (1975) and Hopkins and others (1969) have shown that highly deformed flysch deposits underlie the shelf edge beneath a thick cover of poorly consolidated Neogene sediments. Fossils of Late Cretaceous (probably Campanian) age were found in samples of the flysch dredged from the walls of Pribilof Canyon. This was a particularly important discovery because it appears to bear out earlier suggestions of Burk (1965) that the late Mesozoic continental margin deposits of the Alaska
Peninsula and Koryak-Anadyr region were connected by way of the Bering shelf margin. It also is significant because it establishes the contemporaneity of calcalkaline volcanism on St. Matthew Island and the deposition of flysch sediments at the continental margin.

\section{PLATE TECTONIC INTERPRETATION}

Figure 5 shows the plate model for the Bering Sea region proposed by Scholl, Buffington, and Marlow (1975). Their model suggests that the late Mesozoic boundary between the North American-Eurasian conti-

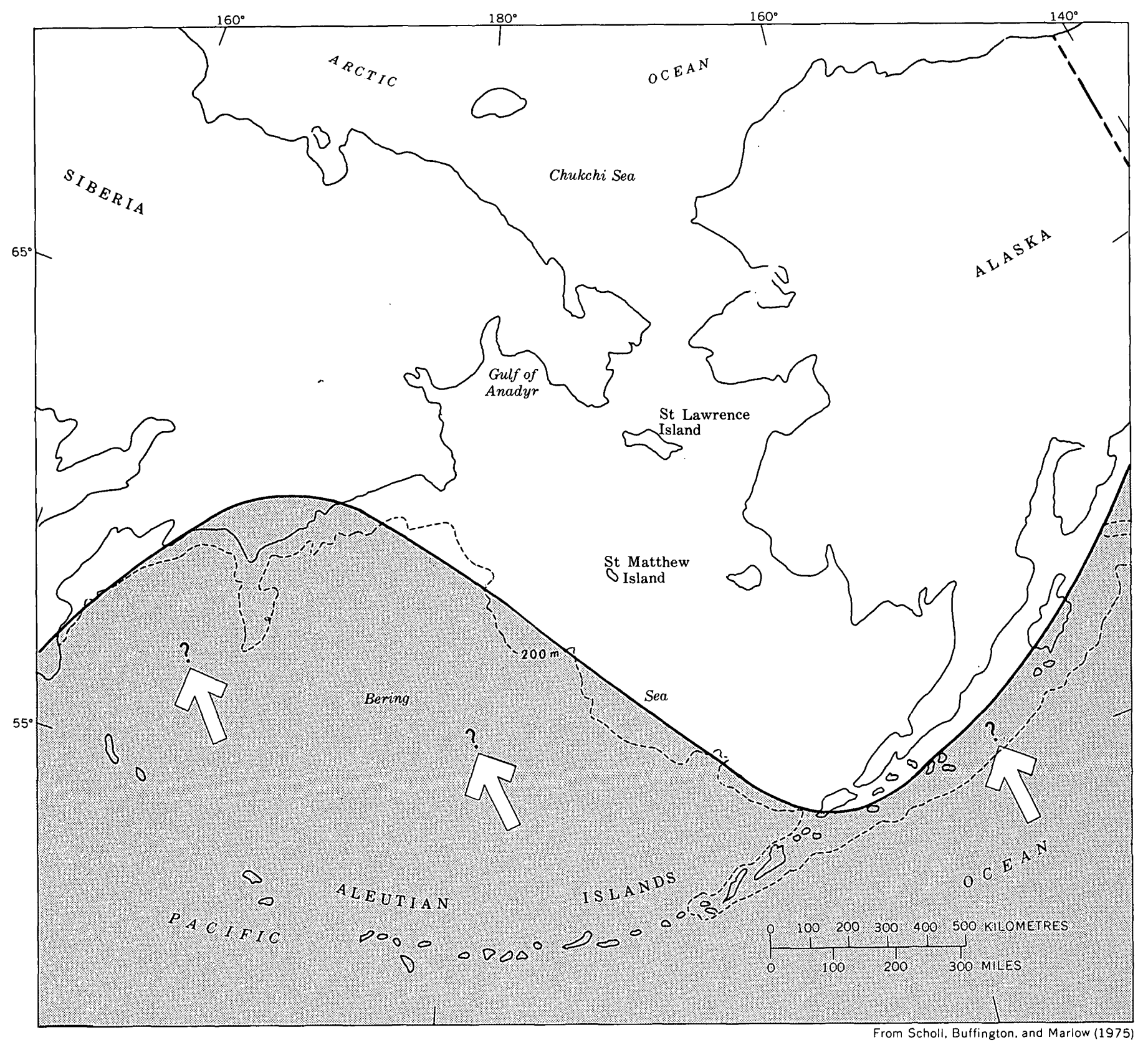

Figure 5.-Boundary between Kula oceanic plate (shaded) and North American-Eurasian plate in the Bering Sea region in late Mesozoic time. Arrows indicate relative plate motion. 
nental plate and the Kula oceanic plate extended from Siberia to Alaska along the present Bering shelf margin. At the end of the Mesozoic or in the early Tertiary the boundary either jumped or migrated to its present position at the Aleutian Trench, isolating the deep Bering Sea basin behind the Aleutian Arc.

This model is supported by the discovery of extensive calc-alkaline volcanism of Late Cretaceous and earliest Tertiary age on St. Matthew Island within a few hundred kilometres of the shelf edge and by the correlation of this volcanism with flysch deposition at the shelf margin.

The relative motion of the Kula plate in this proposed model appears to have been at a small convergence angle with the Bering shelf margin, leading to the suggestion that the margin was a transform fault. Our evidence for an extensive belt of calc-alkaline volcanism parallel to the margin, however, seems to argue for subduction, even though the convergence angle may have been small.

\section{REFERENCES CITED}

Avdeiko, G. P., 1971, Evolution of geosynclines on Kamchatka : Pacific Geology, v. 3, p. 1-14.

Barnes, D. F., and Estlund, M. B., 1975, Gravity map of St. Matthew and Hall Islands, in Patton, W. W., Jr., Miller, T. P., Berg, H. C., Gryc, George, Hoare, J. M., and Ovenshine, A. T., 1975, Reconnaissance geologic map of St. Matthew Island, Bering Sea, Alaska: U.S. Geol. Survey Misc. Field Studies Map MF-642.

Belyi, V. F., 1973, Okhotsk-Chukotsk fold belt and the problem of volcanic arcs in northeast Asia: Am. Assoc: Petroleum Geologists Mem. 19, p. 252-258.

Burk, C. A., 1965, Geology of the Alaska Peninsula-island arc and continental margin: Geol. Soc. America Mem. 99 [in 3 parts].

Cass, J. T., 1959, Reconnaissance geologic map of the Ruby quadrangle, Alaska: U.S. Geol. Survey Misc. Geol. Inv. Map I-289.

Dalrymple, G. B., and Lanphere, M. A., $1971,{ }^{40} \mathrm{Ar} /{ }^{30} \mathrm{Ar}$ technique of $\mathrm{K}$-Ar dating: A comparison with the conventional technique : Earth and Planetary Sci. Letters, v. 12, p. 300-308.

Dawson, G. M., 1894, Geological notes on some coasts and islands of the Bering Sea and vicinity : Geol. Soc. America Bull., v. 5, p. 117-146.

Eakin, H. M., 1918, The Cosna-Nowitna region, Alaska: U.S. Geol. Survey Bull. 667, 54 p.

Emerson, B. K., 1904, General geology-Notes on the stratigraphy and igneous rocks, in volume 4 of Alaska (Harriman Alaska Expedition, 1899) : New York, Doubleday, Page, \& Company, 11-56.

Gladenkov, Iu. B., 1964, O tektonike vostochnoi chasti Koryakskogo Nagor'ya [Tectonics in the eastern part of the Koryak Uplands]: Trudy, Geologicheskii Institut, Akad. Nauk. SSSR, v. 113, p. 7-23.

Hoare, J. M., and Condon, W. H., 1966, Geologic map of the Kwiguk and Black quadrangles, western Alaska: U.S. Geol. Survey Misc. Geol. Inv. Map I-469.
1968, Geologic map of the Hooper Bay quadrangle, Alaska : U.S. Geol. Survey Misc. Geol. Inv. Map I-523.

Hopkins, D. M., Scholl, D. W., Addicott, W. D., Pierce, R. L. Smith, P. B., Wolfe, J., Gershanovich, D., Kotenev, B., Lohman, K. E., Lipps, J. H., and Obradovich, J., 1969, Cretaceous, Tertiary, and early Pleistocene rocks from the continental margin in the Bering Sea: Geol. Soc. America Bull., v. 80, p. 1471-1480.

Irvine T. N., and Baragar, W. R. A., 1971, A guide to the chemical classification of common volcanic rocks : Canadian Jour. Earth Sci., 8, p. 523-548.

Jones, D. L., and Clark, S: H. B., 1973, Upper Cretaceous (Maestrichtian) fossils from the Kenai-Chugach Mountains, Kodiak and Shumagin Islands, southern Alaska: U.S. Geol. Survey Jour. Research, v. 1, no. 2, p. 125-136.

Miller, T. P., Patton, W. W., Jr., and Lanphere, M. A., 1966, Preliminary report on a plutonic belt in west-central Alaska in Geological Survey research 1966: U.S. Geol. Survey Prof. Paper 550-D, p. D158-D162.

Moore, J. C., 1972, Uplifted trench sediments-southwest Alaska-Bering shelf edge: Science, v. 175 , no. 4026 , p. 1103-1105.

Patton, W. W., Jr., and Csejtey, Béla, Jr., 1971, Preliminary geologic investigations of western St. Lawrence Island, Alaska : U.S. Geol. Survey Prof. Paper 684-C, p. C1-C15.

Patton, W. W., Jr., and Miller, T. P., 1973, Bedrock geologic map of Bettles and southern part of Wiseman quadrangles, Alaska: U.S. Geol. Survey Misc. Field Studies Map MF492.

Patton, W. W., Jr., Miller, T. P., Berg, H. C., Gryc, George, Hoare, J. M., and Ovenshine, A. T., 1975, Reconnaissance geologic map of St. Matthew Island, Bering Sea, Alaska : U.S. Geol. Survey Misc. Field Studies Map MF-642.

Patton, W. W.. Jr., and Tailleur, I. L., 1972, Evidence in the Bering Strait region for differential movement between North America and Eurasia [abs.]: Geol. Soc. America Abs. with Programs, v. 4, no. 7, p. 623.

Peacock, M. A., 1931, Classification of igneous rock series : Jour. Geology, v. 39, no. 1, p. 54-67.

Reed, B. L., and Lanphere, M. A., 1973, Alaska-Aleutian Range batholith: Geochronology, chemistry, and relation to circum-Pacific plutonism: Geol. Soc. America Bull., v. 84, p. $2583-2610$.

Scholl, D. W., Buffington, E. C., and Marlow, M. S., 1975, Plate tectonics and the structural evolution of the AleutianBering Sea region, in Forbes, R. B., ed., The geophysics and geology of the Bering Sea region: Geol. Soc. America Spec. Paper 151, p. 1-32.

Tilman, S. M., Belyi, V. F., Nikolaevskii, A. A., and Shilo, N. A., 1969, Tektonika Severo-vostoka SSSR [Tectonics of northeast of U.S.S.R.] : Trudy Severo-Vostochnogo Kompleksnogo Nauchno-Issledovatelskogo Instituta, Sibirskoe Otdelenie Akademii Nauk SSSR, Vyiusk 33, 78 p., Magadan, SSSR.

Verba, M. L., Gaponenko, G. I., Ivanov, S. S., Orlov, A. N., Timofeev, V. I., and Cherenkov, Iu. F., 1971, Glubinnoe stroesue $i$ perspektivy neftigazonosnosti severo-zapadnoi chasti beringova moria-V. sb [Deep structure of northwestern part of the Bering Sea and the prospects of finding oil and gas]: Geofizicheskie metody razvedki $\mathbf{v}$ Arktike $L$, Niiga, vyp 6, p. 70-74. 



\title{
AGE AND ORIGIN OF THE DARROUGH FELSITE, SOUTHERN TOIYABE RANGE, NEVADA
}

\author{
By R. C. SPEED ${ }^{1}$ and E. H. McKEE \\ Evanston, III., Menlo Park, Calif.
}

\begin{abstract}
The name Darrough Felsite was originally assigned to a body of fine-grained quartzofeldspathic igneous rock probably greater than $3 \mathrm{~km}$ thick that is exposed continuously over $100 \mathrm{~km}^{2}$ in the southern Toiyabe Range of central Nevada. The Darrough was supposed to consist mostly of intrusive rocks of probable Permian age. Reexamination of parts of the Darrough Felsite indicates that it is Tertiary and has no genetic affiliation to pre-Tertiary sedimentary and volcanic rocks of the Toiyabe Range. The Darrough constitutes an enormously thick succession of crystal-lithic tuff, tuff breccia, crystal tuff, and volcanogenic sedimentary breccia and sandstone. The tuffaceous rocks are strongly compacted where ash particles are the dominant constituent but are much less compacted where lithic fragments and crystals constitute a rigid framework. Much of the Darrough Felsite may have undergone extensive silicification, probably as a postcompaction event. Contact relations of the Darrough Felsite indicate that it is younger than pre-Tertiary rocks of the southern Toiyabe Range and the Ophir pluton, here dated at 53.9 m.y. (K-Ar, biotite). Three K-Ar ages of minerals from tuff of the Darrough are 26.1, 22.7, and $22.3 \mathrm{~m}$. .., suggesting a middle Tertiary age. A large dike intruding the Darrough, previously assigned a Jurassic age, gives a K-Ar-biotite age of 29.4 m.y. We tentatively interpret the Darrough Felsite to represent an accumulation of ash and breccia flows in a volcanotectonic depression.
\end{abstract}

The name Darrough Felsite was applied by Ferguson and Cathcart (1954) to a large mass of fine-grained siliceous igneous rock that crops out in the southern Toiyabe Range of central Nevada (fig. 1). They believed the mass to be mostly intrusive and suggested that a genetic association exists between it and the nearby partly volcanic Pablo Formation. Because the Pablo was questionably assigned to the Permian, the Darrough Felsite also was considered to be Permian (?). Taken literally, Ferguson and Cathcart's (1954) interpretation of the Darrough Felsite indicates a major episode of silicic volcanism in the southern Toiyabe Range in Permian(?) time. If their age assignment is correct, silicic volcanism must be in-

I Dept. Geological Sciences, Northwestern University. cluded in Permian(?) paleotectonic reconstructions of western and central Nevada.

Preliminary conclusions presented below on the age, origin, and geologic relations of the Darrough Felsite differ from those of Ferguson and Cathcart (1954) and indicate that the Darrough is a thick pile of siliceous tuff, breccia, and possibly lava of middle Tertiary age. We find no genetic relation between the Darrough and the Pablo Formation. There is no convincing evidence of Permian silicic volcanism in the area of the southern Toiyabe Range.

Three possible origins are considered for the Darrough Felsite. It may represent volcanic and epiclastic rocks that filled a volcanotectonic depression; it may be pyroclastic rock that accumulated around the vent of a volcano and became extremely thick owing to caldera collapse and infilling, possibly accompanied by domal intrusion and resurgence; or it may be the product of a large endogenous and exogenous flow-dome complex.

The Darrough Felsite is a physically challenging body of rock to study in the field owing to precipitous slopes and great relief. Complete areal investigation of the unit will require considerable time, and the present preliminary study is of the more accessible parts of the unit.

\section{GEOLOGIC SETTING}

The distribution of the main body of the Darrough Felsite, as modified from Ferguson and. Cathcart (1954), is shown in figure 1. These authors also delineated a sizable body of Darrough Felsite north of the mouth of Peavine Canyon, about $15 \mathrm{~km}$ to the south. We have not examined that body, but F. J. Kleinhampl, oral commun., 1971) believes that it is correlative with rocks mapped as Darrough Felsite of the main body as shown in figure 1 .

Rocks of pre-Tertiary age include early Paleozoic and Permian rocks (Ferguson and Cathcart, 1954), Pennsylvanian rocks (F. J. Kleinhampl, oral commun., 

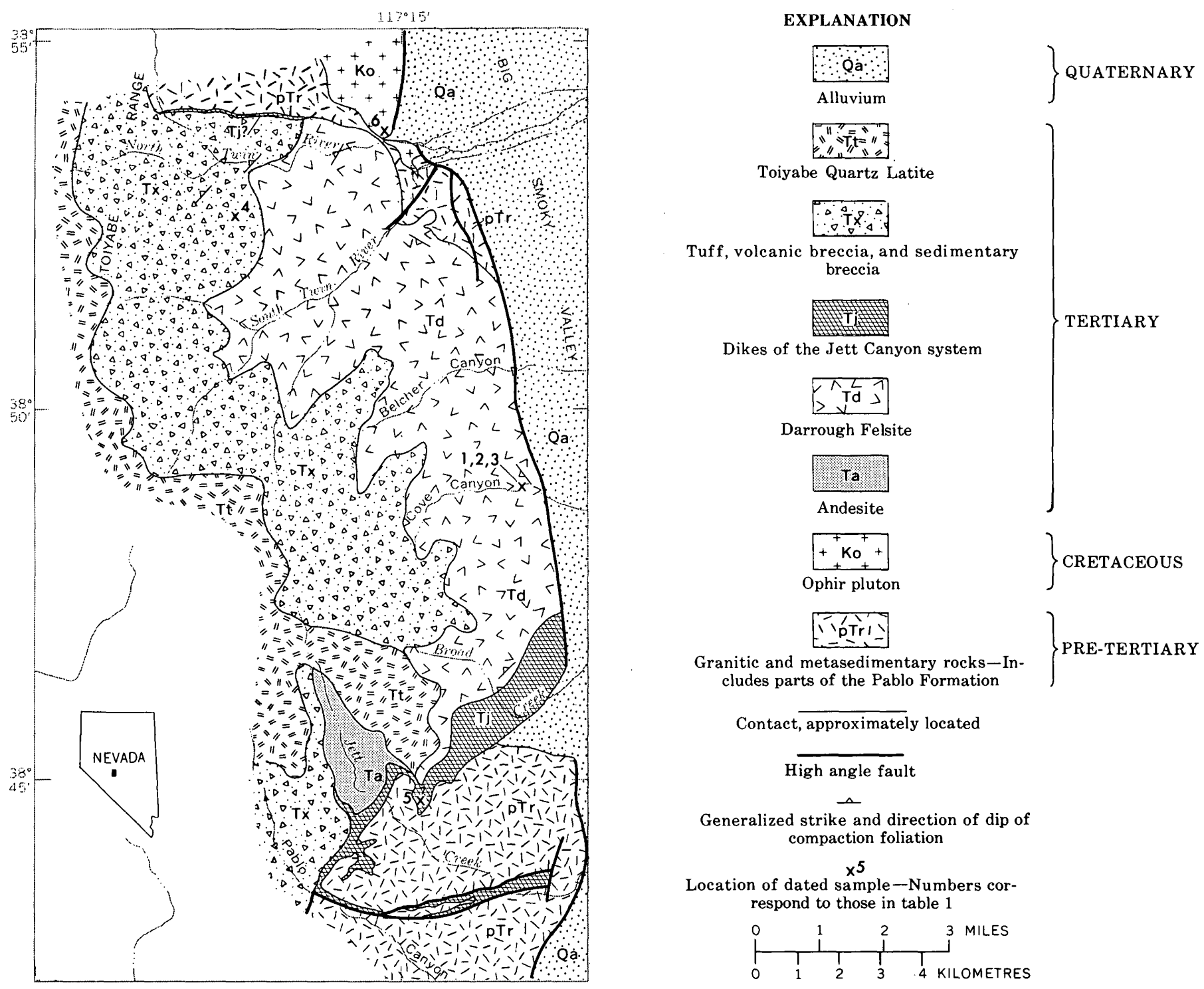

Figure 1.-Geologic map of part of the southern Toiyabe Range, Nev. Modified from Ferguson and Cathcart (1954).

1971), and the Pablo Formation. These are grouped in a single map unit (fig. 1). The Pablo Formation was thought by Ferguson and Cathcart (1954) to lie conformably on Permian conglomerate and to be Permian (?) in age, but it is allochthonous in the Toiyabe Range (Speed, 1973) and can be dated only as older than the 53.9-m.y. K-Ar age of the Ophir pluton (table 1) which intrudes it. The Pablo contains abundant mafic volcanic rock, chiefly basaltic pillow lava, and bedded tuff. $\mathrm{SiO}_{2}$ contents of two fresh-looking clinopyroxene-bearing Pablo basalts are 45.0 and 48.0 percent, and $\mathrm{K}_{2} \mathrm{O}$ contents are less than 0.25 percent. No siliceous volcanic rocks are recognized in the Pablo. All the pre-Tertiary rocks contain at least two sets of tectonic folds, none of which is recognized in the Darrough Felsite.
Tertiary extrusive rocks comprise three units in figure 1, in addition to the Darrough Felsite, with andesite constituting a probable pre-Darrough, basal Tertiary unit. Numerous small erosional remnants of andesite that overlie Mesozoic and Paleozoic rocks in Pablo and Jett Canyons are cut by granitic dikes of the Jett Canyon system, one of which in Jett Canyon is dated at 29.4 m.y. (table 1). Though the Darrough Felsite and the andesite are not in contact, intrusive relations of the dikes and the andesite and the dikes and the Darrough suggest that the andesite is older than the Darrough. We suggest that the andesite may be correlative with similar rocks dated at about $35 \mathrm{~m}$.y. that form the base of Tertiary sections to the north, northwest, and northeast of the area of figure 1 in the Clan Alpine, Shoshone, Toiyabe, and Simpson Park 
TABLE 1.-K-Ar analytical data from samples of the Darrough Felsite and associated rocks, southern Toiyabe Range [Constants : $\mathrm{K}^{40} \lambda_{\epsilon}=0.584 \times 10^{-10} / \mathrm{gr} ; \lambda \beta=4.70 \times 10^{-10} / \mathrm{gr} ;$ atomic at ndant $\mathrm{K}^{* 0}=1.19 \times 10 \rightarrow$. Argon analyzed by scandard isotope dilution techniques on a Neir-type 6-in-radius $60^{\circ}$-sector mass spectrometer. $\mathrm{K}_{2} \mathrm{O}$ analysis by flame photometer using a lithium interna standard. Sample locations in fig. 1]

\begin{tabular}{|c|c|c|c|c|c|}
\hline Sample & $\begin{array}{c}\text { Name and } \\
\text { relation to } \\
\text { Darrough } \\
\text { Felsite }\end{array}$ & $\begin{array}{l}\text { Mineral } \\
\text { and } \mathrm{K}_{2} \mathrm{O} \\
\text { in wt } \\
\text { percent }\end{array}$ & $\begin{array}{c}\text { Radio- } \\
\text { genlc } \\
\Delta \mathbf{r}^{40} \\
(\mathrm{~mol} / \\
\left.\mathbf{g} \times \mathbf{1 0}^{-10}\right)\end{array}$ & $\begin{array}{c}\text { Radio- } \\
\text { genlc } \\
\text { Ar } \\
\text { (per- } \\
\text { cent) }\end{array}$ & $\begin{array}{c}\text { Appar- } \\
\text { ent } \\
\text { age } \\
(\text { m.y. })\end{array}$ \\
\hline $1 \ldots D$ & rrough Felsite - & \multirow{5}{*}{$\begin{array}{l}\text { Sanidine, } \\
13.79, \\
\text { Sanidine, } \\
11.37, \\
\text { Hornblende, } \\
2.37,2.40 . \\
\text { Sanidine, } \\
12.19 \\
\text { Botite, } \\
6.8 \text {. }\end{array}$} & 4.577 & 47 & $22.3 \pm 0.8$ \\
\hline 2 & -_do -.. & & 3.838 & 56 & $22.7 \pm 0.8$ \\
\hline 3.-...- & -_do --_- & & .949 & 49 & $26.7 \pm 1.0$ \\
\hline $4 \ldots-\ldots T$ & $\begin{array}{l}\text { if of intermedi- } \\
\text { ate unit. }\end{array}$ & & 4.125 & 56 & $22.7 \pm 0.8$ \\
\hline & $\begin{array}{l}\text { ate unit. } \\
\text { lartz monzonite } \\
\text { dike intrusive } \\
\text { lnto Darrough } \\
\text { lal Iarrough }\end{array}$ & & 2.981 & 66 & $29.4 \pm 0.8$ \\
\hline 6 & $\begin{array}{l}\text { hir pluton (older } \\
\text { than Darrough } \\
\text { Felsite). }\end{array}$ & $\begin{array}{c}\text { Biotite, } \\
7.29 .\end{array}$ & 5.884 & 83 & $53.9 \pm 1.5$ \\
\hline
\end{tabular}

Ranges (Riehle and others, 1972; McKee and Stewart, 1971; McKee, 1968).

The youngest unit of Tertiary volcanic rocks is the Toiyabe Quartz Latite, a regionally extensive succession of distinctive ash-flow tuffs. The Toiyabe Quartz Latite contrasts markedly with the Tertiary rocks below it because it contains a hign proportion of only moderately compacted tuffs, in sharp contrast to the strongly compacted and locally silicified subjacent tuffs. A K-Ar age of 21.5 m.y. was obtained for the Toiyabe Quartz Latite about $10 \mathrm{~km}$ west of figure 1, (Kleinhampl and Ziony, 1967). The basal contact of this unit shown in figure 1, taken from Ferguson and Cathcart (1954), is apparently an unconformity.

A third Tertiary unit of tuff, volcanic breccia, and sedimentary breccia (fig. 1) corresponds to the Esmeralda Formation of Ferguson and Cathcart (1954) and was designated the middle volcanic unit by Kleinhampl and Ziony in 1967. Although it has some lithologic similarities to the Esmeralda, it is probably mostly older than that formation in its type area. The unit contains tuff and epiclastic volcanic rocks that lie below the Toiyabe Quartz Latite and above the Darrough Felsite over most of the area of figure 1 but below the Toiyabe Quartz Latite and above Tertiary andesite west of Jett Canyon where the Darrough is absent. Future work may prove that this unit includes several unrelated Tertiary units and, in particular, that much of it should be included in the Darrough Felsite.

In the North Twin River drainage (fig. 1), the basal rocks of this unit are about $100 \mathrm{~m}$ of massive epiclastic breccia, microbreccia, and pebbly feldspar-chert sandstone. The breccias contain clasts of pre-Tertiary rocks and Tertiary andesite, dense siliceous volcanic rocks, and quartz. Well-developed bedding in the sandstones is concordant with compaction foliation in subjacent
Darrough Felsite. These sedimentary rocks were assigned by Ferguson and Cathcart (1954) to the Permian Diablo Formation, but such correlation is unlikely because the type Diablo does not contain volcanic fragments and feldspar grains common in these sedimentary rocks. The sedimentary rocks lie above the Darrough as mapped in figure 1 , and they resemble epiclastic rocks locally within the Darrough.

The tuff, volcanic breccia, and sedimentary breccia are conformably overlain by at least $600 \mathrm{~m}$ of densely compacted ash-flow tuff also included in the unit. The tuff contains sanidine, plagioclase, and quartz phenocrysts and sparse aphanitic lithic fragments. Eutaxitic structures are prevalent, but compaction zonation is unrecognized. The tuff has a smaller proportion of crystals and is slightly less dense than typical Darrough Felsite. The greater density of the Darrough is thought to be due to thorough silicification, however, rather than greater compaction. A K-Ar date on sanidine from this tuff (No. 4, table 1) is $22.7 \pm 0.8 \mathrm{~m} . \mathrm{y}$., a nearly identical age to that of two sanidine separates from the Darrough Felsite. The age, degree of compaction, lithologies, and attitude of rocks in the tuff and breccia unit in the North and South Twin River drainages suggest a genetic affiliation of such rocks with the Darrough.

West of Jett and Pablo Canyons (fig. 1), the tuff and breccia unit contains more variably compacted rocks. Such rocks lie above Tertiary andesite, and their relations with the Darrough are unclear.

Figure 1 shows segments of a system of steep dikes that cut pre-Tertiary rocks, Tertiary andesite, and some parts of the Darrough Felsite. These dikes consist variably of rhyolite porphyry, porphyritic granitic rocks, breccia, and, in places, tuff. The siliceous dikes occur in an anastomosing network, here called the dike system of Jett Canyon. Lithic variations in this dike system are both vertical and subhorizontal, perpendicular to the walls, as well as along strike. In general, granitoid rocks occur where the dikes are thick (as much as 500 $\mathrm{m})$, and rhyolite porphyry in dikes that are narrower than $10 \mathrm{~m}$. Breccia dikes contain clasts of older rocks, including Tertiary andesite. Serpentinite occurs along thin dikes and faults between dikes.

\section{DARROUGH FELSITE AS A LITHIC UNIT \\ Previous interpretations}

Ferguson and Cathcart (1954) observed that the Darrough Felsite is largely fine-grained igneous rocks consisting of quartz, $\mathrm{K}$-feldspar, plagioclase, biotite, and devitrified glass. They further noted that welldefined flow handing is widespread and that the rocks are porcelaneous at places but granitoid at others. They felt that such textures perhaps best indicated that 
siliceous lava flows make up much of the Darrough Felsite. Their interpretation that the contacts of the Darrough were all intrusive with respect to older rocks, however, apparently forced a conclusion that the unit is largely an intrusion. Furthermore, Ferguson and Cathcart (1954) found felsite-pebble conglomerate interbedded with so-called flow rocks within the Darrough Felsite. Apparently because of the seeming conflict that the Darrough contains intrusive, extrusive, and sedimentary rocks, Ferguson and Cathcart (1954) assigned the layered rocks, at least in part, to inliers or pendants of the Pablo Formation within the intrusive mass of the Darrough.

A pre-Tertiary age of the Darrough Felsite was assumed by Ferguson and Cathcart (1954) because the Darrough is intruded by granitic rocks assigned by them to the Jurassic(?). They reasoned that an apparent relationship of the Darrough Felsite and the Pablo Formation made probable a Permian age for the Darrough. The correlation of Darrough Felsite and the Pablo Formation was influenced further by the assumption that siliceous flows, lithologically like Darrough Felsite, occur in the Pablo Formation elsewhere.

\section{New observations}

Reconnaissance-investigations indicate that the Darrough Felsite is a thick sequence of .subtly layered rocks consisting of variably compacted crystal-lithic siliceous tuff, tuff breccia, lava, volcanic and sedimentary breccia, and sandstone. The exposed thickness exceeds $2,000 \mathrm{~m}$, and the total thickness is likely to be far greater. Tuff and tuff breccia appear to dominate the sequence. Such rocks are characteristically rich in crystals (average 40 percent phenocrysts), and they commonly contain an abundance of small lithic clasts as well as crystals. Some vertical intervals exceeding $50 \mathrm{~m}$ are made up of very coarse unsorted epiclastic breccia whose clasts are of various sedimentary and metasedimentary rocks, granitic rocks, and other siliceous igneous rocks. Associated with these breccias are local, generally thin intervals of bedded gravel- and sand-sized lithic particles and quartz and feldspar crystals.

Intrusive rocks, such as those mapped by Ferguson and Cathcart (1954) at South Twin River, do exist in the Darrough Felsite. Our reconnaissance indicates, however, that the proportion of intrusive rocks in the Darrough is not as large as originally supposed.

All the layered rocks of the Darrough Felsite, including tuffs, breccias, flows, and sedimentary types, are extremely hard and nonporous. Such properties appear to be uniform throughout the Darrough regardless of degree of compaction of the tuff or degree of sorting in the sediment. Indeed, measurements of the density of tuffs in the Darrough indicate uniformly negligible porosity. The entire body appears to be silicified to some extent, and there is evidence of hydrothermal alteration and weak metamorphism at many places.

The lithologic zoning, bedding in sedimentary rocks, and compaction foliation in tuff are coplanar within local areas. Departures from parallelism exist where compaction foliation of the tuffs is bent in ramp structures and small flowage folds, especially near the base of the unit. General attitudes of planar structures are indicated at several places in figure 1 ; maximum dips are about $45^{\circ}$, but in most places dips are nearly horizontal.

The basal contact of the Darrough Felsite appears to be a regular surface and where it can be walked out near the mouth of North Twin River, it is planar over distances of $100 \mathrm{~m}$. At this locality the contact is an angular unconformity with folded pre-Tertiary rocks. Farther west, the northern boundary of the Darrough is a high-angle fault intruded by a dike lithologically correlated with the dike system of Jett Canyon. At Broad Canyon, a wide segment of the Tertiary Jett Canyon dike system intrudes the contact of the Darrough Felsite and older rocks. Layering in the Darrough at Broad Canyon is concordant to the trend of the dike and is discordant to bedding and fold elements in older rocks to the southeast.

It seems clear that the Darrough Felsite was not deformed with rocks assigned to the Pablo or older pre-Tertiary formations, whose penetrative deformation was completed before emplacement of the Darrough. Furthermore, there appears to be no particular spatial association of the Darrough Felsite and any older rock unit. The Darrough is not a genetic affiliate of the Pablo Formation, as suggested by Ferguson and Cathcart (1954), and the Pablo does not contain siliceous lavas. Foliated rhyolitic rocks that intrude the Pablo as well as other pre-Darrough units in Jett, Pablo, and upper Peavine Canyons are here assumed to be segments of the Tertiary dike system of Jett Canyon.

\section{TUFFACEOUS ROCKS OF THE DARROUGH FELSITE}

Tuffaceous rocks of the Darrough Felsite include three chief intergradational types, here called crystaltuff breccia, crystal-lithic tuff, and distinctly laminated crystal tuff. All contain between 20 and 60 percent crystals and average about 40 percent. The crystal assemblage is rather uniform in the specimens examined. Quartz, at places highly resorbed, is generally more abundant than $\mathrm{K}$-feldspar or plagioclase, which are in 
generally equal proportions. $\mathrm{K}$-feldspar has $2 \mathrm{~V} \approx 25^{\circ}$ and about 12 percent $\mathrm{K}_{2} \mathrm{O}$ (average of two analyses), indicating it is sanidine; plagioclase is mildly zoned and has compositions estimated at $\mathrm{An}_{10}$ to $\mathrm{An}_{20}$. The albite is probably in large part modified to its present composition by hydrothermal alteration. Sparse, coarse biotite flakes are widespread but rare and hornblende phenocrysts occur at a few places. In most specimens, the feldspar phenocrysts appear fresh, whereas the mafic minerals are variably altered. The crystal mode implies that the tuffs are rhyolite to quartz latite or rhyodacite. The matrix of the tuff which was once shards is now uniformly crystallized or devitrified and is a dense microcystalline intergrowth of quartz, $\mathbf{K}$ feldspar, and plagioclase. X-ray diffraction analysis of the matrix suggests that the quartz content exceeds that of feldspar by a factor of 3 or more. Very fine grained secondary brown biotite occurs in crystal tuffs at a few places along certain foliae, enhancing the already conspicuous foliation. Thin veinlets of epidote and chlorite that cut the foliation are scattered throughout the Darrough Felsite. The tuff also contains a widely varying quantity of lithic fragments whose diameters are generally less than $10 \mathrm{~cm}$ and mostly a centimetre or less. The clast types are aphanitic felsic igneous rocks, granitic rocks, chert, slate, quartzite, marble, gray limestone, laminated calcareous siltstone-mudstone, and calc-silicate and pelitic hornfels. The fine-grained igneous clasts are much like the crystal tuff of the Darrough Felsite except that the phenocryst content is lower and the foliation less well developed in the clasts. The clasts of sedimentary and metasedimentary rocks can all be related to rocks in various pre-Tertiary units in the area of figure 1 .

The crystal-tuff breccias contain such a high proportion of lithic clasts that the crystals and clasts in effect constitute a rigid particle framework. The framework evolved in some samples by moderate compaction and welding, and in others, it existed at the time of emplacement by tight grain packing. Relics of devitrified undeformed shards occur abundantly in the framework interstices. Some pumice blocks and lapilli in tuff breccia are squashed, but where they exist between rigid particles, pumice lapilli are relatively undeformed. Foliation in the tuff breccia is defined by the elongation of occasional collapsed pumice clasts. Welding of some degree is apparent in some of the crystal-tuff breccias.

The term "crystal-lithic tuff" is used for rocks in which crystals and lithic fragments are largely suspended in ash, shards, and pumice, all of which are now completely welded and devitrified. Lithic clasts are less plentiful in this rock type than in the tuff breccia. Relict shard textures in most of the crystallithic tuffs show that the tuffs are highly compacted, but they are locally less deformed where protected within clots of rigid particles. The pumice clasts are moderately to strongly compacted. The foliation in the crystal-lithic tuff is subtly to conspicuously eutaxitic. The foliations usually diverge symmetrically about rigid particles, indicating axial compaction. Structures indicating particle rotation are infrequent.

The laminated crystal tuff (fig. 2) contains few, if any, lithic clasts, and it represents the minimum ratio of rigid particles to matrix of the tuffaceous rocks of the Darrough Felsite. The apparent inverse relation of degree of compaction and proportion of rigid particles in the tuffaceous rocks suggests that the laminated crystal tuffs represent the most easily compacted members of a series of tuffaceous rocks that were all subjected to similar compaction loads. This rock type is characterized by nearly continuous lamination that is conspicuous compared to the foliations in the tuff breccias or crystal-lithic tuffs. The lamination is defined by grain size variations in the devitrified quartzofeldspathic microlite matrix and by rare local concentrations of secondary biotite. Rarely, some laminae are lenticular and contain internal coplanar streaks. Such features suggest that the laminae may be collapsed pumice lapilli, at least in part, and provide textural evidence of a pyroclastic origin. Such rocks are thought to be totally compacted and welded tuff, and their laminations may have formed by viscous flow after compaction. Recumbent folds, monoclinic divergence of the foliation about some crystals, and occasional ramp structures indicate that flowage occurred at places in the laminated crystal tuffs (Walker and Swanson, 1968).

A striking feature of the tuffs of the Darrough Felsite is their uniform toughness and apparent lack of porosity. Microscopic observations indicate that porosity is lacking regardless of the primary type of tuffaceous rock or the degree of deformation of relict shards

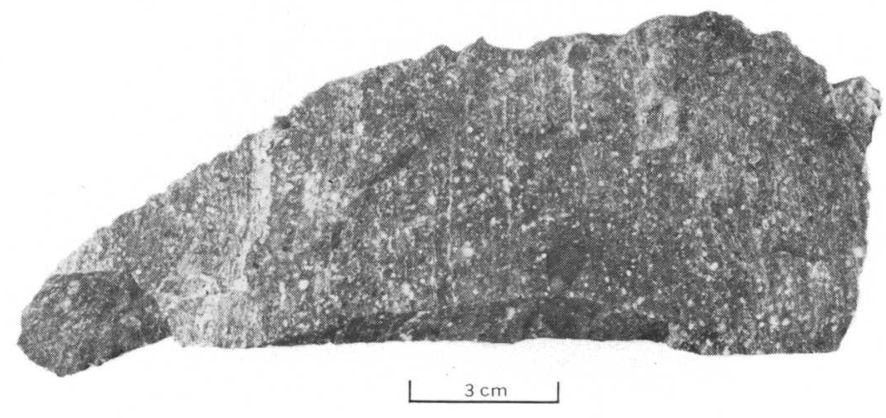

FIGURE 2.-Laminated crystal tuff from area of localities 1, 2, and 3 in figure 1. 
and pumice. Bulk density measurements of eight tuffs of the Darrough are between 2.56 and $2.70 \mathrm{~g} / \mathrm{cm}^{3}$, and the average is $2.64 \mathrm{~g} / \mathrm{cm}^{3}$. The densities indicate that these quartzofeldspathic rocks can contain no pore space, and density measurements during water immersion for $24 \mathrm{~h}$ are constant. Textures imply, however, that compaction of the Darrough Felsite cannot alone have produced the apparent lack of porosity, and we suggest that pervasive silicification in the form of deposition of quartz or quartzofeldspathic minerals from through-going fluids was a major contributing factor. Microcrystalline quartz dominates the matrix of the tuffaceous rocks, and the proportion of matrix quartz is greater than one would predict from the phenocryst assemblage of a rhyolite to rhyodacitic melt. The association of equal amounts of sanidine and albite, which equilibrate only at relatively low temperatures, also suggests modification by hydrothermal solutions or low-grade metamorphism. This interpretation suggests that precipitation in pores was contemporaneous with devitrification and replacement of shards and pumice because such originally glassy fragments are not obviously mineralogically different from the rest of the matrix. Reconnaissance of the Darrough Felsite has not revealed any clear sequence of cooling units or a typical compaction zonation. Such phenomena may be absent, or they may simply be difficult to recognize in the field because of the general uniformity of lithology or pervasive chemical changes in the volcanic pile.

\section{BRECCIA AND SEDIMENTARY ROCKS}

Intercalated with the tuffs in the Darrough Felsite are layers of massive and locally bedded fragmental rocks. Some massive breccias consist of unsorted accumulations of sedimentary and metasedimentary rock fragments as much as a metre in diameter set in a matrix of fine- to medium-grained feldspar-quartzlithic sandstone. Other breccias differ by containing fragments chiefly of aphanitic igneous rock types, probably derived from the Darrough Felsite itself. The breccias in general appear to constitute various mixtures of crystals, lithic clasts, and probably ash from the Darrough with lithic debris from the nonvolcanic terrane that forms the basement in the region. Volumetrically small bodies of rocks associated with the breccias consist of moderately sorted sand-and-peagravel-sized particles in beds and laminations with a thickness of a metre or so.

\section{AGE OF THE DARROUGH FELSITE}

An age for the Darrough Felsite is established from several observations, the first of which is that the de- formation of the Darough is slight compared to that of pre-Tertiary rocks in the area. The base of the Darrough at North Twin River is nearly planar and truncates folded pre-Tertiary formations and contacts. Darrough Felsite was emplaced after the last penetrative deformation of the Pablo Formation, which was probably in Jurassic time or perhaps even later. At the least, the deformational contrast between the Darrough and the Pablo indicates the two units are not coeval.

The Darrough Felsite is also younger thän the Ophir pluton, whose age is a minimum of about 54 m.y. In the vicinity of North Twin River and South Twin River, the Paleozoic rocks are strongly metamorphosed by the Ophir pluton, but unmetamorphosed Darrough Felsite contacts the hornfels around the pluton although it crops out within a few tens of metres of this granitic body. The absence of significant recrystallization of the cryptocrystalline quartzofeldspathic matrix of the Darrough Felsite at North Twin River contrasts markedly with the strong metamorphism of the Paleozoic rocks. Also, the basal part of the Darrough Felsite here contains abundant fragments of granitic rocks, possibly from the Ophir pluton, and clasts of hornfels whose degree of recrystallization contrasts sharply with that of the Darrough matrix.

$\mathrm{K}$-Ar ages on mineral separates from the Darrough Felsite and from associated rocks (table 1) suggest that the Darrough is most likely middle Tertiary in age. It should be noted, however, that all the ages from the Darrough, as well as most of the dates on rocks that might shed light on the age of the formation, are ambiguous in the light of geologic relations and when compared with other dated rocks in central Nevada.

The Ophir pluton, which appears older than the Darrough Felsite on the basis of metamorphic relations, yields an apparent age (but most likely not the crystallization age) of about 54 m.y. (No. 6, table 1) and serves as a lower limit for the age of the Darrough. Ash-flow tuff of the tuff and breccia unit that lies on top of the Darrough has an age of 22.7 m.y. (No. 4, table 1) which is considered a minimum age for the Darrough.

Age determinations on the Darrough Felsite itself include two analyses on different sanidine separates from the same specimen that are $22.3 \pm 0.8$ m.y. and $22.7 \pm 0.8$ m.y. (Nos. 1 and 2, table 1) and homblende from a second sample (No. 3, table 1) that yields an age of $26.7 \pm 1.0$ m.y. This spread may represent real differences in age between different parts of the felsite body, or the younger sanidine age may reflect some postemplacement heating or alteration event. 
An age of $29.4 \pm 0.8$ m.y. on biotite (No. 5, table 1 ) from quartz monzonite porphyry of the Jett Canyon dike system that cuts the Darrough Felsite suggests that the Darrough may be older than the 22-27-m.y. age of the minerals from the body itself. The 29.4-m.y. age, however, is here considered less reliable than the ages obtained directly on the Darrough, and, considering the contact relations of units, is probably anomalously old.

Considering all the dates, the geologic relations, and the nature of the Darrough and nearby rocks, a middle Tertiary age seems warranted for the Darrough Felsite.

\section{DIKES ASSOCIATED WITH THE DARROUGH FELSITE}

On the north side of the Darrough Felsite in the area of figure 1 , dikes of siliceous igneous rocks like those of the Jett Canyon system cut pre-Tertiary rocks, and in particular they intrude faults in the vicinity of the Darrough contact. North of the Twin River drainage, siliceous dikes are sparse, suggesting as in Jett Canyon that dikes are concentrated near the margin of the Darrough Felsite.

Reconnaissance indicates that the substrate to the Darrough Felsite is strongly faulted and intruded by dikes that are of similar composition to the Darrough. In addition many dikes contain lithic fragments similar to those in the pyroclastic parts of the overlying felsite. Because stratigraphic relations and radiometric ages indioate that the dike system, at least in Jett Canyon, is penecontemporaneous with the Darrough Felsite, we suggest that the dike system was the plumbing through which magmas of the Darrough Felsite were transferred from depth.

\section{ORIGIN OF THE DARROUGH FELSITE}

The Darrough Felsite is a thick, areally restricted accumulation of crystal-rich pyroclastic rocks and epiclastic beds that were deposited as a succession of ash and breccia flows. The thick tuff accumulation is interpreted to lie above and perhaps adjacent to its feeder system and is intruded by such feeders. The thickness of tuff suggests deposition in a topographic depression, and the abundance of faults in the Darrough substrate associated with the inferred feeder dike system suggests that structural subsidence was related to eruption of the tuffs.

The high degree of compaction of the laminated crystal tuffs suggests that the material accumulated rapidly so that little heat was lost between ash flows and the ontire pile reached high temperatures throughout. Flow banding common in some places indicates that compaction and heating were great enough to cause local late flowage.

We suggest that the Darrough Felsite is a strongly compacted tuff pile that accumulated in a middle Tertiary volcanotectonic depression or caldera. The widespread, pervasive silicification and the alteration of this volcanic sequence contrast markedly with the features observed in other similar bodies of extrusive rock from similar volcanic centers of Tertiary age in central Nevada. The reason for these phenomena is unknown.

\section{REFERENCES CITED}

Ferguson, H. G., and Cathcart, S. H., 1954, Geology of the Round Mountain quadrangle, Nevada: U.S. Geol. Survey Geol. Quad. Map GQ-40, scale 1:125,000.

Kleinhampl, F. J., and Ziony, J. I., 1967, Preliminary geologic map of northern Nye County, Nevada: U.S. Geol. Survey open-fle map, scale 1:200,000.

McKee, E. H., 1968, Geologic map of the Ackerman Canyon quadrangle, Lander and Eureka Counties, Nerada: U.S. Geol. Survey Geol. Quad. Map GQ-761, scale 1:62,500.

McKee, E. H., and Stewart, J. H., 1971, Stratigraphy and potossium-argon ages of some Tertiary tuffs from Lander and Churchill Counties, central Nevada: U.S. Geol. Survey Bull. 1311-B, p. B1-B25.

Riehle, J. R., McKee, E. H., and Speed, R. C., 1972, Tertiary volcanic center, west-central Nevada: Geol. Soc. America Bull., v. 83, p. 1383-1396.

Speed, R. C., 1973, Excelsior and Pablo Formations, western Nevada; problems and progress in analysis [abs.]: Geol. Soc. America, Abs. with Programs, v. 5, no. 1, p. 109-110.

Walker, G. W., and Swanson, D. A., 1968, Laminar flowage in a Pliocene soda rhyolite ash-flow tuff, Lake and Harney Counties, Oregon, in Geological Survey research, 1968: U.S. Geol. Survey Prof. Paper 600-B, p. B37-B48. 



\title{
PETROLOGY OF THE PALOMA VALLEY RING COMPLEX, SOUTHERN CALIFORNIA BATHOLITH
}

\author{
By D. M. MORTON and A. K. BAIRD, \\ Menlo Park and Claremont, Calif.
}

\begin{abstract}
The Paloma Valley ring complex is one of the numerous plutons that make up the Cretaceous southern California batholith. The complex is composite, consisting of (1) an older, single ring dike and two subsidiary short-arced inner dikes, and (2) a younger set of thin short-arced dikes largely inside the older ring dike. The older ring dike, composed of granodiorite-quartz monzonite, has nearly vertical walls and is elliptical in plan; its long axis $(14 \mathrm{~km})$ is oriented west-northwest. It was emplaced in and contains numerous fragments of gabbro. The more than 200 shortarced granitic pegmatite dikes, mainly ranging from 0.2 to $1 \mathrm{~m}$ in thickness, define a domal ring dike set with moderately to steeply dipping outer dikes and nearly horizontal inner dikes. The younger dikes cut both the older ring dike and the gabbro. Spatially associated with the younger dikes are bodies of fine-grained granophyre that contain stringers of granitic pegmatite. The granophyre has an $\mathrm{Mg}$ content similar to that of the younger ring-dike rock, but contains less $\mathrm{K}$ and more $\mathrm{Fe}$. The older ring dike is interpreted to have been magmatically emplaced in an elliptical zone of ring fracturing in gabbro; the magma made room by stoping the denser gabbro with little assimilation. Upon a release of pres. sure, a set of domal fractures formed, along which volatilerich magma was emplaced, forming the younger ring dikes. Granophyre resulted from pressure-quenching through a loss of volatiles. Residual volatiles, or volatiles that were introduced later, recrystallized parts of the granophyre and caused the formation of pegmatite stringers.
\end{abstract}

Ring dikes, generally considered unequivocal evidence of magmatism, appear to be rare in the composite southern California batholith, if the number of published descriptions is any indication. Only two ring structures, one near Ramona, Calif. (Merriam, 1941), and another about $35 \mathrm{~km}$ south of the United StatesMexico border (Duffield, 1968), have been reported. Mapping in the northern part of the batholith has revealed a third ring complex heretofore undescribed. This complex, named the Paloma Valley ring complex (Morton and Baird, 1971), is $40 \mathrm{~km}$ south of Riverside on the southwest margin of the Perris block, a part of the Peninsular Ranges province of southern California. The Perris block is a rectangular area of low relief between the northwest-striking San Jacinto and Elsi-

\footnotetext{
1 Dept. of Geology, Pomona College, Claremont, Callf.
}

nore fault zones (fig. 1). For an account of the geomorphic history of the general area, see Woodford and others (1971).

Although rocks of the ring complex have not been dated, other plutons in the batholith are of early Late Cretaceous age. Absolute ages cluster around 100 m.y. (Banks and Silver, 1962; Evernden and Kistler, 1970; Larsen and others, 1958; Morton, 1969; and Silver, 1971). Two potassium-argon dates from the granodiorite adjacent to the ring complex are $91.2( \pm 2.6)$ $\times 10^{6}$ and $89.5( \pm 1.8) \times 10^{6} \mathrm{yr}$. The ring complex is located within the area described in Larsen's memoir on the batholith (1948), and the northern part of the complex is within the Lake Elsinore 15-minute quadrangle mapped by Engel (1959).

The Paloma Valley ring complex consists of two parts (1) a ring dike with two subsidiary short-arced

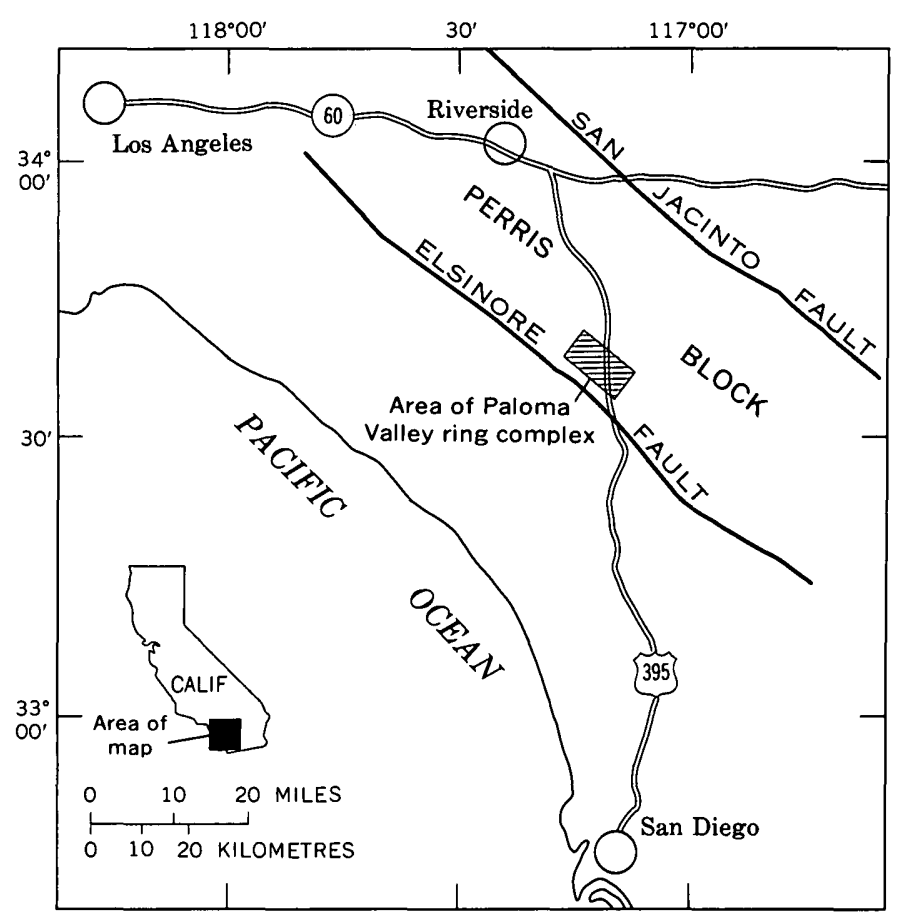

Figure 1.-Map of coastal southern California showing location of the Paloma Valley ring complex. 
inner dikes, and (2) a younger set of thin, short-arced dikes, largely inside the older ring dike (fig 2). A number of bodies of fine-grained granophyre occur with the younger set of dikes (fig. 3). In plan the complex is elliptical, with a long axis of $14 \mathrm{~km}$, oriented west-northwest, approximately parallel to the regional structural grain of the Peninsular Ranges. Gabbro and lesser amounts of granodiorite, schist, and mixed granodiorite-quartz diorite make up the ringdike country rock. Much of the western edge of the complex is covered by alluvium in the trough along the Elsinore fault.

\section{COUNTRY ROCKS}

The principal country rock is hornblende gabbrothe San Marcos Gabbro of Miller (1937) and Larsen (1948). It is typically massive, medium to coarse grained, and composed of subhedral plagioclase $\left(\approx A n_{50}\right)$ and green-brown hornblende, with accessory epidote, sphene, chlorite, opaque minerals, and, in

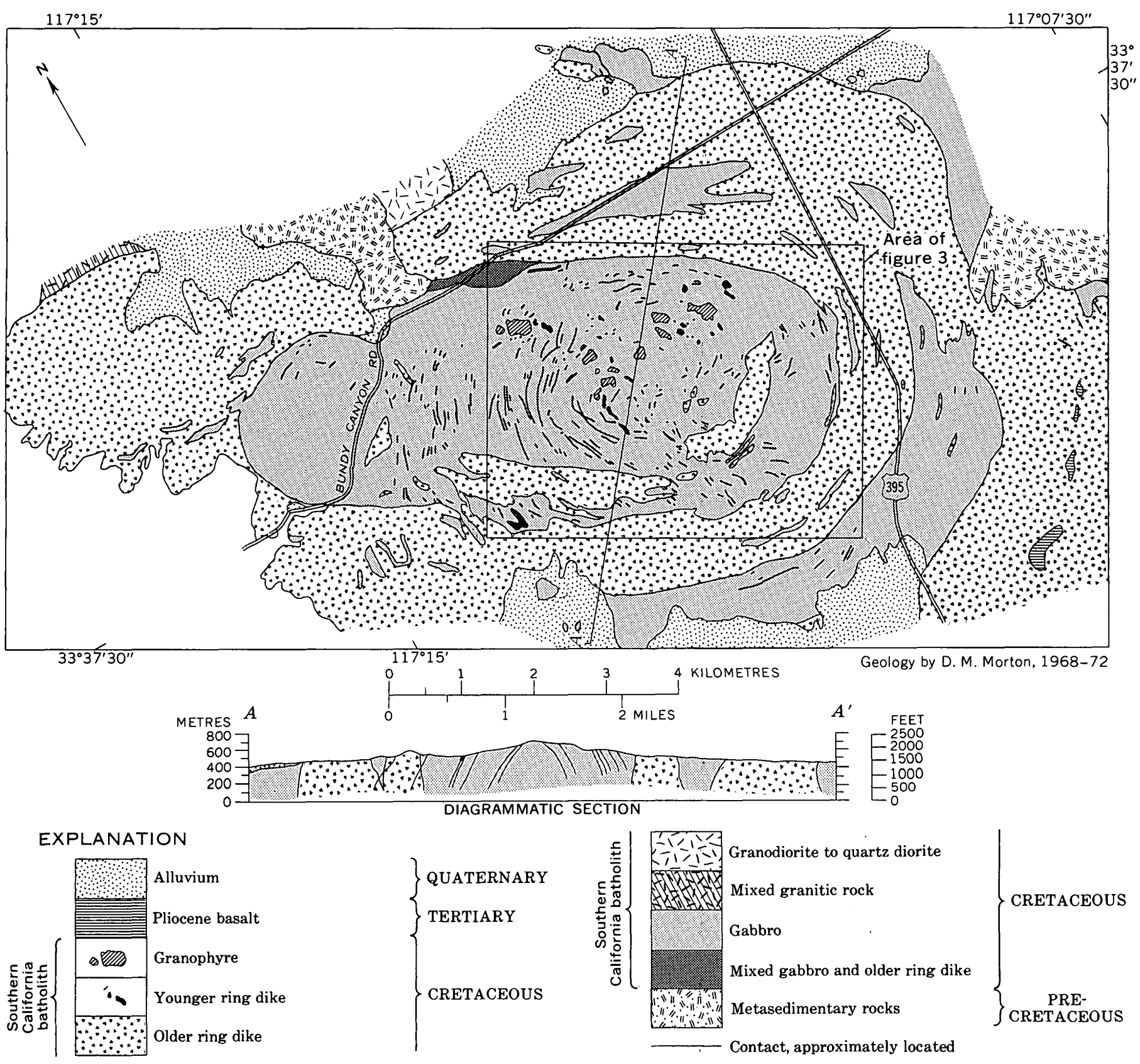

Figure 2.-Generalized geologic map and section of the Paloma Valley ring complex, southern California. 


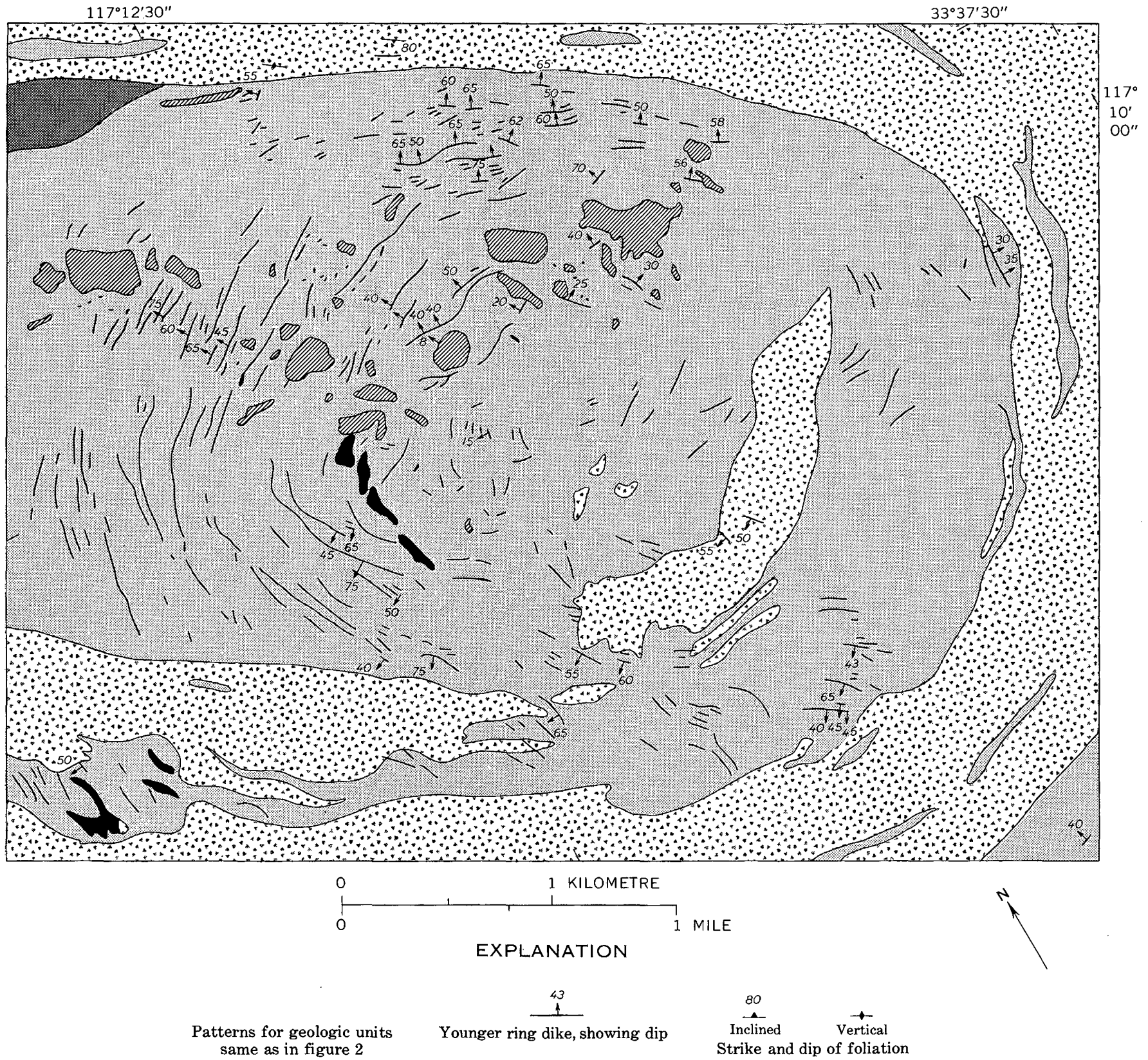

Figure 3.-Geologic map of the central part of the Paloma Valley ring complex.

places, quartz. It weathers readily to smooth slopes. Chemical analyses of three samples are given in table 1 ; specific gravity ranges from 2.92 to 2.97 , with a mean value $(\dot{\bar{x}})$ of 2.95 .

In many ring complexes (for example, Harker, 1904; King, 1955) a close genetic relation appears to exist between gabbro and granite. For the Paloma Valley ring complex, existing exposures preclude establishment or denial of a close genetic relation except that both dikes and gabbro are part of the southern California batholith.
TABLE 1.-Chemical composition of gabbro country rock [Analyses by X-ray fluorescence spectrography. Total iron calculated as $\left.\mathrm{Fe}_{2} \mathrm{O}_{3}\right]$

\begin{tabular}{|c|c|c|c|c|c|c|c|c|c|}
\hline Sample & $\mathrm{SiO}_{2}$ & $\mathrm{Al}_{2} \mathrm{O}_{3}$ & $\mathrm{Fe}_{2} \mathrm{O}_{3}$ & $\mathrm{MgO}$ & $\mathrm{CaO}$ & $\mathrm{Na}_{2} \mathrm{O}$ & $\mathbf{K}_{2} \mathrm{O}$ & $\mathrm{TiO}_{2}$ & Total \\
\hline$x-1$ & 53.14 & 16.10 & 9.49 & 5.89 & 10.7 & 2.88 & 0.59 & 0.93 & 99.79 \\
\hline 2 & 46.79 & 19.41 & 11.41 & 6.85 & 11.23 & 2.49 & .22 & 1.03 & 99.43 \\
\hline $3 \ldots$ & 51.40 & 14.10 & 12.30 & 5.88 & 9.60 & 3.47 & .58 & 1.25 & 98.58 \\
\hline
\end{tabular}

Some of the northern part of the ring complex is in contact with massive plutonic rock that ranges in composition from hornblende-biotite granodiorite to quartz diorite, the Domenigoni Valley Granodiorite of Larsen (1948). It is mainly a massive, medium- 
grained rock generally devoid of any primary structures.

Mixed granitic rock of quartz dioritic and granodioritic composition occurs along the northwest margin of the complex.

The otherwise unbroken outer dike of the complex is interrupted on the northern side by a septum of schist and quartzite; similar metamorphic rocks occur on the east end of the complex. These rocks are of low metamorphic grade and are part of the French Valley Formation of Schwarcz (1969) or the Bedford Canyon Formation (Larsen, 1948).

\section{OLDER RING DIKE}

The rock of the older ring dike ranges from granite to granodiorite, is generally light colored, medium grained, and hypautomorphic-granular. Most of the rock is biotite (or hornblende-biotite) quartz monzonite and granodiorite, part of the Woodson Mountain Granodiorite of Larsen (1948). Plagioclase $\left(\mathrm{An}_{20-35}\right)$ occurs as subhedral tabular crystals. Quartz and K-feldspar, largely microcline, occur as anhedral masses. Subhedral to irregular sheaves of biotite and ragged hornblende crystals make up less than 10 percent of the rock, with biotite much more widespread than hornblende. In general, the rock is more mafic in the southeastern part of the complex, where it grades into quartz diorite. Chemical analyses of seven samples from the older ring dike are given in table 2 ; specific gravity of the rock ranges from 2.66 to $2.72(\bar{x}=2.69)$.

TABLE 2.-Chcmical composition of older ring dike rock [Analyses by $\mathrm{X}$-ray fluorescence spectrography. Total iron calculated as $\mathrm{Fe}_{2} \mathrm{O}_{3}$ ]

\begin{tabular}{|c|c|c|c|c|c|c|c|c|c|}
\hline Sample & $\mathrm{SiO}_{2}$ & $\mathrm{Al}_{2} \mathrm{O}_{3}$ & $\mathrm{Fe}_{3} \mathrm{O}_{3}$ & Mgo & $\mathrm{CaO}$ & $\mathrm{Na}_{2} \mathrm{O}$ & $\mathrm{K}_{2} \mathrm{O}$ & $\mathrm{THO}_{2}$ & \\
\hline 7 & 80 & & 1.05 & 0.06 & 03 & 2.92 & 3.2 & 0.10 & \\
\hline & & & 4 & 0 & & & & .32 & \\
\hline & 71 & & 4. & 1.20 & & 2. & 1. & .53 & \\
\hline & 74 & & 2. & .61 & & & & .27 & \\
\hline & 74 & 14 & 2.2 & .41 & & 4. & 2. & .23 & 100 \\
\hline & 68 & 15 & 4.39 & 1.23 & & & & .48 & \\
\hline & 75.80 & 12.90 & 1.49 & .33 & 1.23 & 4.20 & 3.59 & .17 & \\
\hline
\end{tabular}

Most of the rock is massive. Sparse mineral foliation indicates that the dike is essentially vertical.

Numerous gabbro inclusions occur in the ring dike and range in size from less than $1 \mathrm{~cm}$ to $3,000 \mathrm{~m}$. They are of various shapes, although most of the larger fragments appear to be tabular. A number of large fragments $(150-300 \mathrm{~m})$ in the southern part of the complex are platelike and oriented subhorizontally. Platy gabbro fragments in the northern and eastern parts of the complex tend to be oriented subvertically. Smaller fragments are in various stages of digestion, whereas most of the larger fragments retain their original mineralogy and texture and are sharply bounded.

Stringers and irregular masses of skarnlike garnetpyroxene rock occur in a few places in the southcentral part of the complex. These masses range from less than $1 \mathrm{~cm}$ to $10 \mathrm{~cm}$ in width and occur within quartz monzonite.

\section{YOUNGER RING-DIKE SET}

Several hundred thin, arcuate granitic dikes occur over an area of $24 \mathrm{~km}^{2}$ and cut the gabbro and older ring dike (fig. 3). These dikes, largely inside the older ring dike, range in thickness from a few centimetres to several metres; most are 0.3 to $1 \mathrm{~m}$ thick. They range in length from 10 to $900 \mathrm{~m}$. The distribution and orientation of these dikes define a domal roofed ring structure that has a geometric center about $1 \mathrm{~km}$ southeast of the geometric center of the older ring dike. The dips of the dikes flatten from $50^{\circ}-70^{\circ}$ at the outer part of the structure to subhorizontal near the center.

Most dikes are texturally and compositionally zoned. Outer zones consist of granitoid-textured, coarsegrained granite composed of quartz, perthite, and sodic plagioclase, with or without biotite, and minor magnetite. Inner or core zones consist of pegmatitic-textured perthite, sodic plagioclase, quartz, biotite, and (or) muscovite, with accessory magnetite, schorl, garnet, and epidote. Vugs lined with crystals of quartz and muscovite, and rare masses of pyrite as much as $10 \mathrm{~cm}$ in diameter, occur in bulbous pegmatite dikes with massive quartz cores. Graphic intergrowths of quartz and perthite are common in rock transitional between granitoid and pegmatitic-textured types. Dikes that lack pegmatitic cores consist entirely of coarse- to extremely coarse-grained granitoid-textured rock, with or without graphic intergrowths.

Most dike rock has a specific gravity of about 2.66 . Representative chemical analyses are given in table 3 .

TABLE 3.-Chemical composition of younger dike rocks [Analyses by $\mathrm{X}$-ray fluorescence spectrography. Total iron calculated as $\mathrm{Fe}_{2} \mathrm{O}_{3}$ ]

\begin{tabular}{|c|c|c|c|c|c|c|c|c|c|}
\hline Sam & $\mathrm{SiO}_{2}$ & $\mathrm{Al}_{2} \mathrm{O}_{3}$ & $\mathrm{Fe}_{2} \mathrm{O}_{3}$ & $\mathrm{AgO}$ & $\mathrm{CaO}$ & $\mathrm{Na}_{2} \mathrm{O}$ & $\mathrm{K}_{2} \mathrm{O}$ & $\mathrm{THO}_{2}$ & o \\
\hline & & & & & & & & & \\
\hline 2 & & & & & & & & & \\
\hline & 77. & & . & & .60 & & & & 98.27 \\
\hline & 78. & & .6 & $<.0$ & .67 & & & .03 & 99.17 \\
\hline 5 & 78.15 & 11.58 & 1.10 & $<.05$ & .63 & 3.18 & 4.12 & .08 & 98.89 \\
\hline
\end{tabular}

\section{GRANOPHYRE}

More than 50 bodies of granophyre, ranging in length from $<10 \mathrm{~m}$ to $>600 \mathrm{~m}$, cut the gabbro, principally within the north-central part of the complex. The granophyre is resistant to erosion and crops out chiefly on topographic highs. The overall geometry of 
most of these bodies cannot be determined. Lower contacts of granophyre bodies with the gabbro were seen in only a few bodies near the center of the younger ring structure. The contacts are nearly horizontal and are parallel to adjacent granitic dikes of the younger ring dike.

The granophyre is very fine grained and slightly porphyritic, with phenocrysts of altered plagioclase in groundmass of granophyric intergrowths of quartz within microcline and sodic plagioclase. Pyrite is a ubiquitous accessory, and its weathering turns the outcrops a characteristic red-brown. Representative chemical analyses are given in table 4 .

TABLE 4.-Chemical composition of granophyre [Analyses by X-ray fluorescence spectrography. Total iron calculated

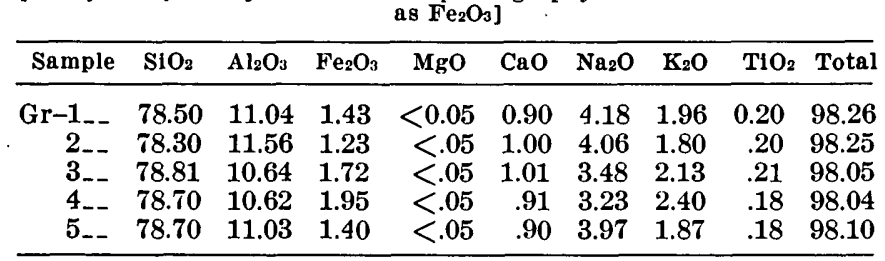

Numerous, thin $(1-3 \mathrm{~cm})$, discontinuous stringers of granitic pegmatite cut the granophyre. These stringers are confined to the granophyre and appear to lack systematic orientation. They are zoned both textually and compositionally. Most have margins consisting of aplite, composed of sodic plagioclase and quartz with or without minor K-feldspar. The aplite passes gradationally outward into granophyre. The centers of the stringers are pegmatoid and are themselves compositionally zoned. Three types of zoning are present in the pegmatoid part of the dikes, two symmetric and one asymmetric: (1) symmetric zoning having a central $K$-feldspar and quartz core surrounded by a layer of sodic plagioclase and quartz where tabular plagioclase crystals are subnormal to the walls of the pegmatite and increase in width toward the core, (2) symmetric zoning having a quartz core surrounded by K-feldspar and quartz, and (3) asymmetric zoning having two layers parallel to the length of the dike-one layer is composed of plagioclase and quartz and the other of K-feldspar and quartz; the thickest bodies have massive quartz cores, some of which contain minor muscovite, biotite, magnetite and rarely schorl and garnet.

Only a few oriented samples of the pegmatite stringers could be obtained. From these it appears that the asymmetrically zoned pegmatite stringers are oriented subhorizontally with the $\mathrm{K}$-feldspar-rich zone constituting the hanging wall.

\section{INTERPRETATION}

Only two ring structures within the southern California batholith have been previously described. Mer- riam (1941) described a quartz dioritic body with a concentric structure "suggestive of ring dike" (p. 365) near Ramona, $45 \mathrm{~km}$ south of the Paloma Valley ring complex. More recently Duffield (1968) wrote a detailed description and analysis of a curious ring structure in the El Pinal area, Baja California, $35 \mathrm{~km}$ south of the international border. Both of these structures differ markedly from the Paloma Valley ring complex.

Lack of relief and paucity of internal structures prevent accurate determination of the subsurface geometry of the older ring dike. The few observed "flow" structures suggest that the walls of the older ring dike are nearly vertical or dip steeply inward. Ring fracturing, accompanying an upwelling of magma and stoping of the gabbro country rock, seems to best explain the development of the older ring dike.

However, during the emplacement of the older ring dike, two competing processes should have been operating-assimilation and stoping. Although the relatively siliceous metamorphic country rock would be assimilated at a faster rate than the gabbro, it appears that the gabbro could be stoped even faster than the country rock could be assimilated.

The massive gabbro may have behaved as an isotropic medium that reacted uniformly to the stresses producing the ring fracturing. The disruption of the ring structure where the gabbro and metamorphic rocks are interfingered is considered a result of the differences in mechanical behavior between the gabbro and metamorphic rock. Either the metamorphic rocks did not fracture, as did the gabbro, or they were not dense enough to be mechanically incorporated by gravity settling into the ring-dike magma, as was the gabbro.

Comparison of the chemistry of the gabbro with the range of chemistry of the older ring-dike rock places limits of the quantity of gabbro that could have been assimilated. The $\mathrm{MgO}$ content of the older ring-dike rock ranges from 0.06 percent to 1.23 percent. The $\mathrm{MgO}$ content of three samples ranges from 5.88 to 6.85 percent $(\bar{x}=6.20$ percent $)$. In the limiting case (initial $\mathrm{MgO}$ content of the older ring-dike magma $= \pm 0$ percent), the $\mathrm{MgO}$ content would require assimilation of between 1 and 20 percent gabbro by weight. The mean $\mathrm{MgO}$ content of seven samples of the older dike rock is 0.55 percent. If this value is representative, and it is essentially all inherited through the incorporation of gabbro, then an average of only 9 percent by weight of gabbro was incorporated to give rise to the quartz monzonite-granodiorite. Thus. most of the gabbro must have been removed by physical means. The occurrence of gabbro within the dike rock and the density contrast $(>0.26)$ between the two rock types indicate physical removal by stoping. No 
evidence was found that would suggest forceful emplacement.

The configuration of the younger ring-dike set is that of a classical domal ring-dike complex, but the set includes more dikes than have been reported to occur in other such complexes. We suggest that after emplacement of the older ring dike, diminishing pressure resulted in "collapse" of the gabbro and older dike rock at the level exposed today, resulting in numerous domal fracture sets. Upward pressure could have been reduced, for example, by cauldron subsidence as ring fracturing reached the surface. Volatile-rich, residual magma from the largely crystallized older ring-dike rock was emplaced in the fractures to form the younger pegmatitic ring dike.

The granophyre, located within the north-central part of the complex, is spatially related to the younger dike rock and at least one body is horizontally floored. as are the subhorizontal dikes. Chemically, the granophyre is similar to the younger dike rock in having a low magnesium content but dissimilar in having considerably lower potassium and higher iron.

We suggest that part of the magma that formed the younger ring dike was emplaced in extremely low pressure domains within the domal fracture set, where it rapidly lost its volatile content; pressure-quenching of the volatile-poor remaining magma resulted in the formation of the granophyre. If this explanation is correct, then the origin of the granophyre is similar to the proposed origin of aplite dikes through pressurequenching of pegmatitic fluids resulting from loss of volatiles (Jahns and Tuttle, 1963).

Jahns and Tuttle (1963) found experimental evidence indicating that potassium is preferentially extracted over sodium by a vapor and "can travel rapidly through the vapor in response to a temperature gradient" (p. 90). This mechanism could explain the difference in potassium content between the granophyre and younger dike rock. The granophyre could be viewed as an extreme case of a pressure-quenched plutonic rock, more rapidly quenched, or less recrystallized. than those aplites formed through pressure-quenching.

The chemical difference between the granophyre and younger dike-rock is easily seen by comparing plots of normative albite, orthoclase, and quartz on a ternary diagram (fig. 4).

Pegmatite stringers cutting the granophyre are thought to result from local recrystallization of the granophyre, either through action of sparse residual volatiles or later introduced voltiles, perhaps from granophyre forming nearby. The sodic plagioclaserich and $\mathrm{K}$-feldspar-deficient pegmatite margins resulted from potassium, with volatiles, preferentially moving from the margins inward to form the pegma-

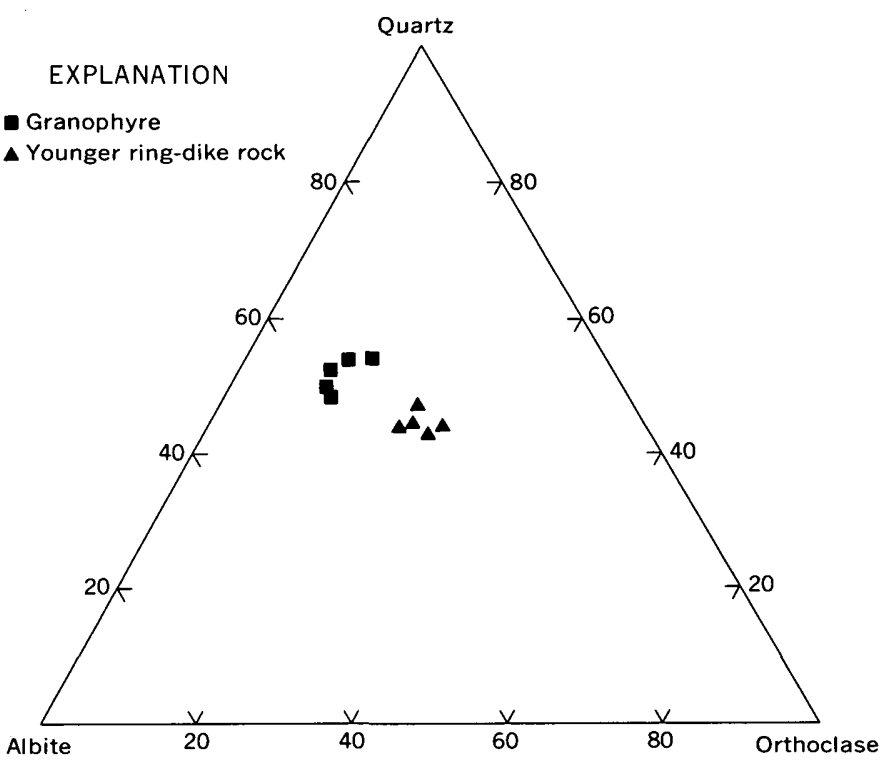

Figure 4.-Ternary plot of normative albite, orthoclase, and quartz for younger ring-dike rock and granophyre.

titic cores. Asymmetrically zoned pegmatite cores were produced in essentially horizontal stringers through the concentration of potassium- and volatile-rich magma against the hanging wall. Thus, they are similar to other asymmetrically zoned pegmatites.

\section{REFERENCES CITED}

Banks, P. O., and Silver, L. 'T., 1962, Petrological and geochronological observations on the Rubidoux Mountain lencogranites, Riverside County, California: Geol. Soc. America Spec. Paper 68, p. 5-6.

Duffield, W. A., 1968, The petrology and structure of the El Pinal tonalite, Baja California, Mexico: Geol. Soc. America Bull., v. 79, p. 1351-1371.

Fngel, René, 1959, Geology of the Lake Elsinore quadrangle: California Div. Mines and Geology Bull. 146, $154 \mathrm{p}$.

Evernden, J. F., and Kistler, R. W., 1970, Chronology of emplacement of Mesozoic batholithic complexes in California and western Nevada: U.S. Geol. Survey Prof. Paper 623, $42 \mathrm{p}$.

Harker, Alfred, 1904, The Tertiary igneous rocks of Skye: Geol. Survey Scotland Mem., 481 p.

Hurlbut, C. S., 1935, Dark inclusions in a tonalite of southern California: Am. Mineralogist, v. 20, p. 609-630.

Jahns, R. H., and Tuttle, O. F., 1963, Layered pegmatiteaplite intrusives: Mineralog. Soc. America Spec. Paper 1, p. 78-92.

King, B. C., 1955, The Ard Bheinn area of the central ring complex of Arran: Geol. Soc. London Quart. Jour., v. 110, p. 323-355.

Larsen, E. S., Jr., 1948, Batholith and associated rocks of the Corona, Elsinore, and San Luis Rey quadrangles, southern California: Geol. Soc. America Mem. 29, 182 p.

Larsen, E. S., Jr., Gottfried, David, Jaffe, H. W., and Waring, C. I., 1958, Lead-alpha ages of the Mesozoic batholiths of western North America: U.S. Geol. Survey Bull. 1070-B, $62 \mathrm{p}$. 
Merriam, R. H., 1941, A southern California ring dike: Am. Jour. Sci., v. 239, p. 365-371.

Miller, F. S., 1937, The petrology of the San Marcos gabbro, southern California: Geol. Soc. America Bull., v. 48, p. 1397-1425.

Morton, D. M., 1969, The Lakeview Mountains pluton, south ern California batholith-Part 1, Petrology and structure: Geol. Soc. America Bull., v. 80, p. 1539-1552.

Morton, D. M., and Baird, A. K., 1971, The Paloma Valley ring complex, southern California batholith: Geol. Soc. America Abs. with Programs, v. 3, no. 2, p. 167.
Schwarez, H. P., 1969, Pre-Cretaceous sedimentation and metamorphism in the Winchester area, northern Peninsular Ranges, California: Geol. Soc. America Spec. Paper 100, $63 \mathrm{p}$.

Silver, L. T., 1971, Problems of crystalline rocks of the Transverse Ranges: Geol. Soc. America Abs. with Programs, v. 3 , no. 2, p. 193-195.

Woodford, A. O., and Shelton, J. S., Doehring, D. O., and Morton, R. K., 1971, Pliocene-Pleistocene history of the Perris block, southern California: Geol. Soc. America Bull., v. 82 , p. $3421-3448$. 



\title{
HALOGEN CONTENTS OF IGNEOUS MINERALS AS INDICATORS OF MAGMATIC EVOLUTION OF ROCKS ASSOCIATED WITH THE RAY PORPHYRY COPPER DEPOSIT, ARIZONA
}

\author{
By NORMAN G. BANKS, Menlo Park, Calif.
}

\begin{abstract}
The contents of $\mathrm{Cl}, \mathrm{F}$, and $\mathrm{H}_{2} \mathrm{O}+$ (calculated) in some hydrous igneous minerals in intrusive rocks of Laramide age $(70-60$ m.y.) near Ray, Ariz., appear to be related to the age and the chemistry of the whole-rock samples. Apatite and biotite in younger, more silicic rocks contain more $F$ but less $\mathrm{Cl}$ and $\mathrm{H}_{2} \mathrm{O}+$ than apatite and biotite in older, more maflc rock; the same relations hold for $\mathrm{F}$ and $\mathrm{H}_{2} \mathrm{O}+$ in sphene. Correlations of the abundance of $\mathrm{Cl}, \mathrm{F}$, and $\mathrm{H}_{2} \mathrm{O}+$ in hornblende with rock chemistry and age are not as strong as for apatite, biotite, and sphene; igneous(?) epidote does not contain $\mathrm{Cl}$ and $\mathrm{F}$ in amounts detectable by electron microprobe analysis. The contents of $\mathrm{Cl}, \mathrm{F}$, and $\mathrm{H}_{2} \mathrm{O}+$ in wholerock samples decrease with increasing differentiation index and decreasing age. Data for a single pluton of variable composition mirror the results for a suite of different plutons and dikes. The data are satisfactorily although not exclusively explained by postulating that the melts each contained progressively less $\mathrm{Cl}, \mathrm{F}$, and $\mathrm{H}_{2} \mathrm{O}$ and that the hydrons minerals consumed most of the $\mathrm{Cl}, \mathrm{F}$, and $\mathrm{H}_{2} \mathrm{O}$ in the magmas. The data may also be explained by postulating that (1) the stocks evolved Cl-bearing water during their ascent and crystallization, or that (2) $\mathrm{Cl}$ and $\mathrm{H}_{2} \mathrm{O}$ were concentrated during differentiation of the stocks but the minerals failed to record their buildup. Both alternative explanations find problems with and require special conditions to satisfy field, chemical, and experimental data. If many of the special conditions are not met, a nearby batholithic parent to the stocks is not a favorable source of the mineralized fluids at Ray. Propylitic alteration of biotite results in $\mathrm{Cl}$-poor chlorites and may have provided some $\mathrm{Cl}$ to hydrothermal fluids; biotite may have also supplied some $F$ to propylitizing fluids through alteration.
\end{abstract}

This study provides data on the concentrations of $\mathrm{Cl}$, $\mathrm{F}$, and $\mathrm{H}_{2} \mathrm{O}$ in the intrusive bodies and their hydrous minerals related in time and space with the porphyry copper deposit at Ray, Ariz. These and accompanying whole-rock petrochemical data allow interpretation of the magmatic behavior of $\mathrm{Cl}, \mathrm{F}$, and $\mathrm{H}_{2} \mathrm{O}$ prior to deposition of ore. Microprobe and wet-chemistry analyses for $\mathrm{Cl}, \mathrm{F}$, and $\mathrm{H}_{2} \mathrm{O}+$ of mineral grains and wholerock samples of least altered Laramide intrusive rocks, of mineral grains in least altered Precambrian igneous rocks (Ruin Granite, 1.4 b.y.; diabase, 1.2 b.y.), and of hydrothermal biotite from the deposit are reported. The igneous minerals studied are apatite, biotite, hornblende, sphene, and epidote; secondary minerals include chlorite, epidote, sphene, phengite, and hydrogarnet (?).

The samples used in the microprobe studies were collected at sites indicated in figure 1 and include 7 of at least 12 rock types intruded in the vicinity of the Ray deposit during a 10-m.y. period (70-60 m.y. ago; Banks and others, 1972; Banks and Stuckless, 1973). Ages, differentiation indices, textures, the $\mathrm{Fe}-\mathrm{Mg}$ silicates present, and percentage of alteration of selected minerals in the Laramide igneous rocks are listed in table 1. Whole-rock chemical and petrologic data have been obtained on one or more samples of each of the 12 rock types. At least 11 of these rock types are cut by sulfide veinlets; part of this veining occurs outside of presently commercial ground.

The deposit, located about $120 \mathrm{~km}$ north of Tucson and $120 \mathrm{~km}$ east of Phoenix, Ariz. formed about 60 m.y. ago (Banks and Stuckless, 1973). The main hosts of the hypogene sulfides (pyrite, chalcopyrite, and molybdenite) are schist, Ruin Granite (a quartz monzonite), quartzite, and diabase, all of Precambrian age. The center of mineralization occurs near the westcentral edge of the Sonora quadrangle (fig. 1).

Acknowledgments.-The manuscript was improved by many fruitful discussions with $\mathrm{N}$. J Page and the helpful reviews by W. J. Moore, N. J Page, H. D. Holland, D. R. Wones, and H. R. Cornwall. The manuscript also benefited from reviews of some of the sections by R. O. Fournier and C. L. Christ. Part of the modal data used for material balance estimates in this report was contributed by $H$. R. Cornwall. R. Dockter aided in data compilation and drafting. Oliver Ingamels (now with Climax Molybdenum Co., Golden, Colo.) provided the scapolite standard (No. 63-1805) for the $\mathrm{Cl}$ analyses. 


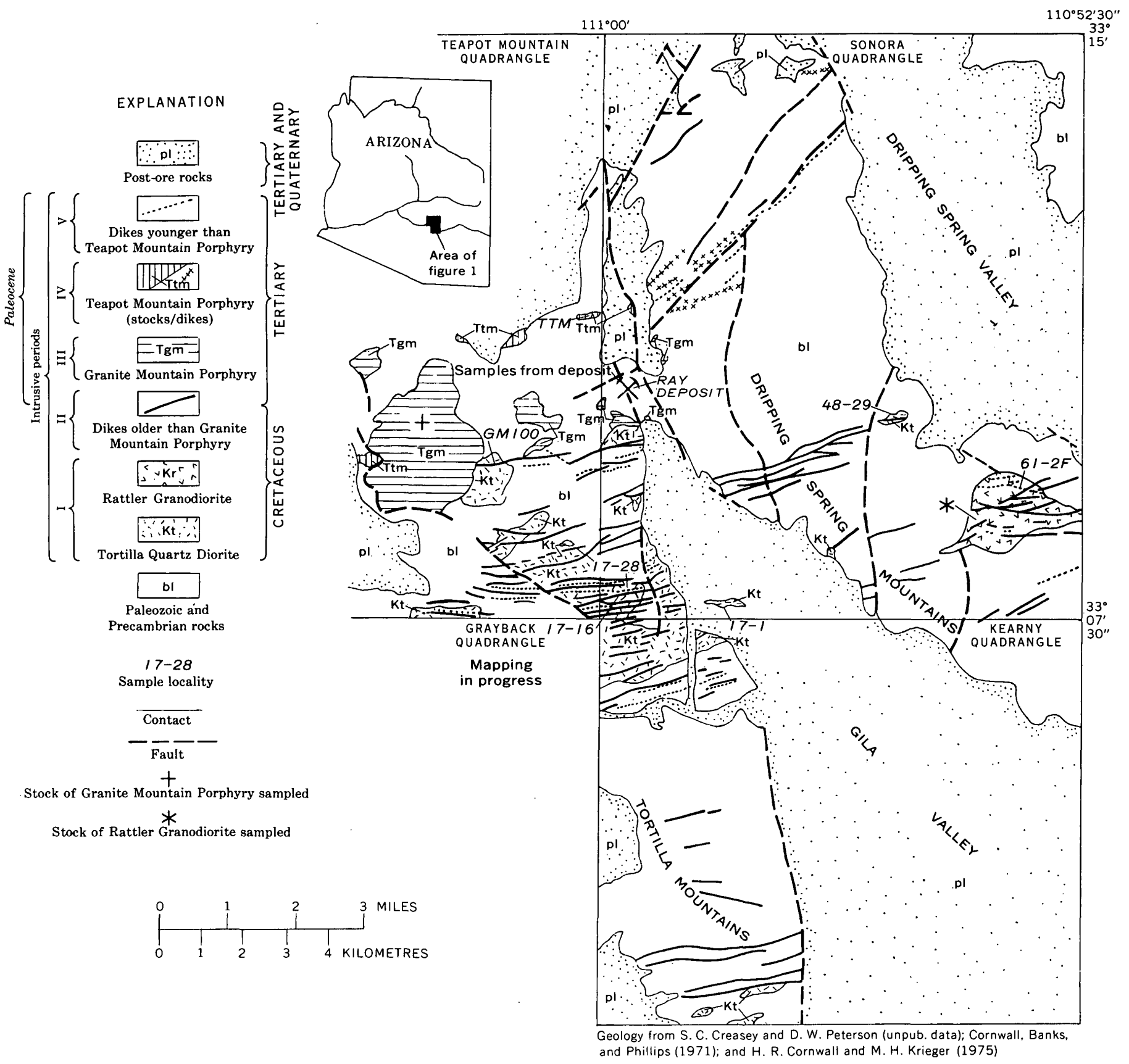

Figure 1.-General geology and sample locations.

\section{BACKGROUND GEOLOGY AND PETROLOGY OF LARAMIDE IGNEOUS ROCKS}

Laramide igneous bodies near Ray were intruded in roughly five periods (fig. 1) that may or may not represent a nearly continuous sequence. One or more major plutons, representing five rock types, were emplaced during each of the first four intrusive periods. The samples for microprobe study came from four of these five major rock types. The excepted rock type represents a granodiorite stock of intrusive period II (63 m.y. old) in the Grayback quadrangle (not shown in fig. 1). Rhyodacitic to quartz latitic dikes were emplaced in intrusive periods II, IV, and V. Samples of the dikes for microprobe study came from two rock types of period II (samples 17-16 and GM100, table 1) and one type of period V (sample 61-2F, table 1).

Bulk compositions of the major Laramide plutons are progressively more felsic (increasing differentiation index) with decreasing age of the intrusive type; these ages were determined on the basis of geologic 
TABLE 1.-Sample data, Laramide rock8

\begin{tabular}{|c|c|c|c|c|c|c|c|}
\hline \multirow{2}{*}{$\underset{\text { sample }}{\text { Rock }}$} & \multirow{2}{*}{$\begin{array}{l}\text { Rock } \\
\text { differen- } \\
\text { tiation } \\
\text { index }{ }^{2}\end{array}$} & \multirow[b]{2}{*}{ Texture } & \multicolumn{3}{|c|}{ Mafic silicates present } & \multirow{2}{*}{$\begin{array}{l}\text { Percentage } \\
\text { of mafic } \\
\text { minerals } \\
\text { altered }{ }^{3}\end{array}$} & \multirow{2}{*}{$\begin{array}{c}\text { Percentage } \\
\text { of plagio- } \\
\text { clase } \\
\text { altered }\end{array}$} \\
\hline & & & $\begin{array}{c}\text { Pyrox- } \\
\text { ene }\end{array}$ & $\begin{array}{l}\text { Horn- } \\
\text { blende }\end{array}$ & $\begin{array}{l}\text { Bio- } \\
\text { tite }\end{array}$ & & \\
\hline \multicolumn{8}{|c|}{ Tortilla Quartz Diorite $\left(71-70\right.$ m.y.) ${ }^{s}$} \\
\hline $\begin{array}{l}17-28 \\
17-1 \\
48-29\end{array}$ & $\begin{array}{l}51.4 \\
51.9 \\
53.2\end{array}$ & $\begin{array}{l}\text { Intersertal } \\
-1 \\
-\end{array}$ & $\begin{array}{l}x \\
x \\
x\end{array}$ & $\begin{array}{r}\times \\
\left({ }^{8}\right) \\
\times\end{array}$ & $\begin{array}{l}x \\
x \\
--\end{array}$ & $\begin{array}{c}\text { Trace } \\
19.5 \\
10.0\end{array}$ & $\begin{array}{r}16.0 \\
5.0 \\
45.0\end{array}$ \\
\hline \multicolumn{8}{|c|}{ Rattler Granodiorite (70 m.y.) } \\
\hline $\begin{array}{l}46-99 B \\
60-113 D \dagger \\
60-108 \\
60-114 \dagger^{*} \\
61-25 \dagger \\
60-91 \\
60-111 \\
60-124^{*} \\
60-98 \\
46-11 G \\
60-131 \\
60-130 \\
60-132^{*} \\
60-96 A \\
46-11 A \\
\text { T16-630‡ }\end{array}$ & $\begin{array}{l}48.4 \\
64.7 \\
72.3 \\
72.2 \\
72.4 \\
72.5 \\
72.7 \\
72.8 \\
75.2 \\
75.4 \\
76.4 \\
76.9 \\
77.7 \\
87.3 \\
93.3 \\
71.5\end{array}$ & $\begin{array}{l}\text { Hypidiomorphic-seriate } \\
\text { Porphyritic } \\
\text { Hypidiomorphic-seriate } \\
\text { Porphyritic } \\
\text { Seriate porphyritic } \\
\text { Chilled } \\
\text { Hypidiomorphic-seriate } \\
\text { - do do - } \\
\text { Seriate porphyritic } \\
\text { Hypidiomorphic-seriate } \\
\text { Aplitic - do - } \\
\text { Seriate porphyritic }\end{array}$ & 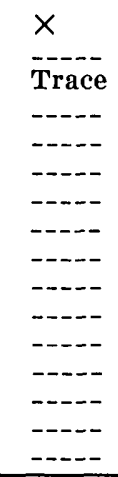 & $\begin{array}{l}x \\
x \\
x \\
x \\
x \\
x \\
-\bar{x} \\
x \\
x \\
-- \\
-- \\
-- \\
-- \\
-\bar{x}\end{array}$ & $\begin{array}{l}x \\
x \\
\bar{x} \\
\bar{x} \\
x \\
x \\
x \\
x \\
x \\
x \\
x \\
x \\
x \\
x \\
x \\
x\end{array}$ & $\begin{array}{c}1.3 \\
11.3 \\
\text { Trace } \\
2.4 \\
8.2 \\
11.0 \\
2.0 \\
13.3 \\
1.7 \\
9.6 \\
8.3 \\
9.0 \\
17.7 \\
72.5 \\
72.2 \\
---- \\
\end{array}$ & $\begin{array}{r}6.6 \\
3.8 \\
1.0 \\
3.0 \\
3.5 \\
11.2 \\
0.6 \\
10.0 \\
3.6 \\
10.5 \\
7.1 \\
6.3 \\
7.1 \\
26.7 \\
35.9 \\
--- \\
\end{array}$ \\
\hline \multicolumn{8}{|c|}{ Granite Mountain Porphyry (61-60 m.y.) } \\
\hline $\begin{array}{l}\text { RB5 } \\
\text { GM14 } \\
\text { GM12 } \\
\text { GM18 } \\
\text { GM6G } \\
\text { GM1A } \\
\text { GM2A } \\
\text { GM4V }\end{array}$ & $\begin{array}{r}79.7 \\
80.5 \\
81.8 \\
81.9 \\
83.5 \\
94.7 \\
94.7 \\
--- \\
\end{array}$ & $\begin{array}{l}\text { Granitoid } \\
\text { Seriate porphyritic } \\
\text { Porphyritic } \\
\text { Granitoid } \\
\text { Seriate porphyritic } \\
\text { Aplitic } \\
\text { Porphyritic }\end{array}$ & 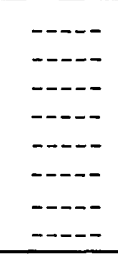 & $\begin{array}{c}-- \\
-- \\
\text { Trace } \\
-- \\
-- \\
-- \\
--\end{array}$ & $\begin{array}{l}x \\
x \\
x \\
x \\
x \\
x \\
x \\
x\end{array}$ & $\begin{array}{r}46.0 \\
12.5 \\
13.6 \\
5.7 \\
9.2 \\
100.0 \\
85.7 \\
16.7 \\
\end{array}$ & $\begin{array}{r}39.5 \\
12.1 \\
11.3 \\
9.0 \\
2.3 \\
41.0 \\
21.0 \\
2.5 \\
\end{array}$ \\
\hline \multicolumn{8}{|c|}{ Teapot Mountain Porphyry (61-60 m.y.) } \\
\hline Ttm $\dagger$ & 83.6 & Porphyritic -- & ----- & $x$ & $x$ & 100.0 & 68.0 \\
\hline \multicolumn{8}{|c|}{ Rhyodacite dikes $^{8}$} \\
\hline $\begin{array}{l}17-16 \dagger \\
\text { GM100† } \\
61-2 F \dagger\end{array}$ & $\begin{array}{r}74.0 \\
80.0 \\
81.0\end{array}$ & 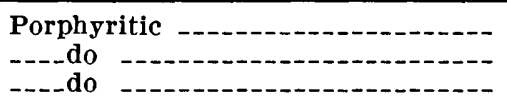 & $\begin{array}{l}---- \\
---- \\
-\cdots--\end{array}$ & $\begin{array}{l}x \\
x \\
x\end{array}$ & $\begin{array}{l}x \\
x \\
x\end{array}$ & $\begin{array}{l}43.2 \\
42.0 \\
86.3\end{array}$ & $\begin{array}{r}58.8 \\
52.3 \\
7.8\end{array}$ \\
\hline
\end{tabular}

† Samples with phenocrystic magnetite and hydrous phases.

* No mineral analyses.

$\ddagger$ No modal analysis.

${ }_{1}^{A}$ numeral 2 or 3 preceding the sample numbers in the following tables indicates that the prohe mount is a duplicate or triplicate sample. ${ }^{2}$ Modified from Thornton and Tuttle (1960): uses quartz plus albite plus K-feldspar from molecular catanorm rather than the CIPW norm. 3 Percentage of the Mg-Fe minerals in the rock converted to secondary minerals.

4 Percentage of the plagioclase in the rock converted to secondary minerals.

5 Ages from Banks and Stuckless (1973); Banks and others (1972).

Tibrous amphibole reaction rims on pyroxene.

Aplite assumed to have approximately same differentiation index as sample GM2A.

8 Ages as follows: Sample $17-16(<69,>63 \mathrm{~m} . \mathrm{y}$. $)$; sample GM 100 (63 m.y.) ; sample $61-2 \mathrm{~F}$ (questionable, either $70 \mathrm{~m} . \mathrm{y}$. or $<60 \mathrm{~m} . \mathrm{y}$.).
8 Rock analysis from the same dike type but not the same dike used for the mineral analyses.

relations and potassium-argon and fission-track ages (table 1). Compositions of the dike rocks are not all intermediate between those of rock types that they crosscut and that crosscut them. However, standard petrochemical plots of whole-rock normative minerals, major elements, and trace elements indicate that the magmas of both the dikes and the stocks of Laramide age near Ray developed along smooth chemical trends (Banks and others, 1972). The results are compatible with, although not proof of, either consanguinity or a common-source partial melting origin of the igneous suite. Various facies of the Rattler Granodiorite al- most duplicate in one intrusive mass the chemical, textural and mineralogical variations that occur in the entire suite studied (table 1). This allows comparison of the behaviors of $\mathrm{Cl}, \mathrm{F}$, and $\mathrm{H}_{2} \mathrm{O}$ in one magma with their behaviors in a series of magmas intruded in the 10-m.y. period. Stratigraphic reconstructions indioate that during Laramide time the presently exposed rocks were at depths ranging from not more than $1.5 \mathrm{~km}$ to at least $3 \mathrm{~km}$. Concordance of apatite fission-track ages with other mineral ages places a maximum depth for the exposed rocks and deposit at $5 \mathrm{~km}$ during and since Laramide time (Banks and Stuckless, 1973). Depths of 
emplacement of the individual plutons studied may have differed by $1.5 \mathrm{~km}$ or more.

Several petrochemical observations suggest, although admittedly do not prove, that the stocks and dikes did not saturate early in their crystallization history or evolve much water. The Mg content of the biotite decreases slightly with increasing differentiation index of the sample and, more strikingly, with decreasing sample age (fig. 2). This reducing trend may represent undersaturation of the melt in regard to water (Wones and Eugster, 1965). Additionally, (1) the percentage of aplites in the stocks is low; (2) there is a paucity of pegmatitic aplites; (3) metamorphic aureoles around the intrusive bodies, both stocks and dikes, are very restricted and in some places are virtually absent even in carbonate terrane; (4) miarolitic features or cavities have not been identified in field exposures or thin sections of the Laramide stocks; and (5) J. T. Nash (written commun., 1971, 1972) and M. J. Logsdon (oral commun., 1973) find that the fluid inclusions in quartz in the rocks are sparse, two phase, relatively dilute, and homogenize at temperatures below $450^{\circ} \mathrm{C}$.

Another petrologic observation that might indicate the degree of saturation of the magmas at their emplacement is the amount of melt crystallized prior to the first formation of the hydrous minerals. For example, at their depths of emplacement, the melts should have contained about 2.5-3.0 wt percent $\mathrm{H}_{2} \mathrm{O}$ before
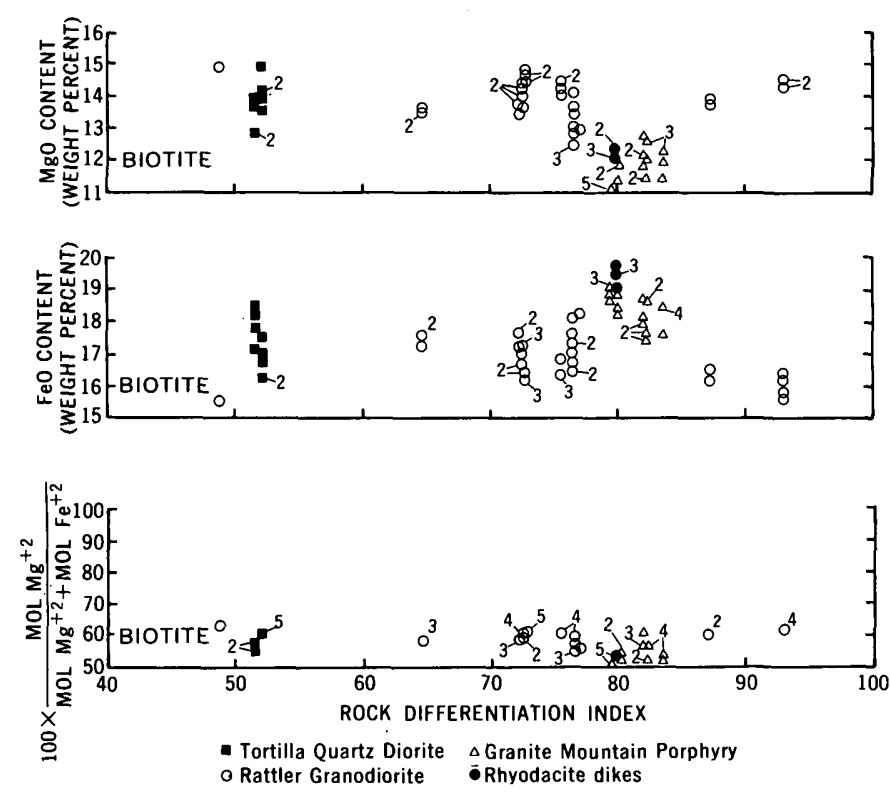

Figure 2.-Variation of $\mathrm{MgO}, \mathrm{FeO}$, and

$100 \times \mathrm{mol} \mathrm{Mg}^{+2}$

$\mathrm{mol} \mathrm{\textrm {Mg } ^ { + 2 } + \mathrm { mol } \mathrm { Fe }} \mathrm{e}^{+2}$

in biotite with rock differentiation index. All Fe in biotite is assumed to be in the reduced state for plotting. biotite formed (D. R. Wones, oral commun., 1973; Wones and Dodge, 1966). Thus, if biotite first formed in a stock when it was 50 percent crystallized, the magma presumably had less than $1.5 \mathrm{wt}$ percent initial $\mathrm{H}_{2} \mathrm{O}$. However, as described below, not only is it difficult to determine with surety when the hydrous minerals first began forming in the magmas, but also the petrologic relations can be interpreted to indicate that a given mineral began forming at different times in the same magma.

In the porphyritic variants of the Rattler Granodiorite and in the rhyodacite dikes and Teapot Mountain Porphyry (flagged by daggers in table 1), anhedral (fig. $3 A$ ) to euhedral (fig. $3 B$ ) phenocrysts of hornblende, biotite, and anhydrous minerals are set in either an aplitic or felty groundmass composed mainly of quartz, K-feldspar, and, in some samples, also plagioclase, opaque minerals, hornblende, or biotite. Accessory apatite occurs as subhedral to euhedral grains and as inclusions, mostly in biotite. Sphene rims magnetite phenocrysts, is intergrown with biotite and hornblende, or locally is found as separate, subhedral to anhedral medium-sized grains. Provided that growth rate of the hydrous minerals did not greatly exceed the growth rate of the anhydrous minerals, these relations suggest that the hydrous:minerals began forming in the magma before the groundmass, which makes up 30-50 percent of the rocks in this group of samples. However, in the other samples of the Rattler Granodiorite (not flagged by daggers in table 1) and in all samples of the Tortilla Quartz Diorite and Granite Mountain Porphyry (including porphyritic varieties), the hydrous minerals are interstitial to plagioclase (forming roughly 50 percent of the rocks) and are spatially associated with interstitial aplitic to oikocrystic $\mathrm{K}$-feldspar and quartz (fig. 3D-H; fig. $4 A$ ). In the more felsic samples of this group, some of the larger K-feldspar and quartz grains (perhaps another 20-30 percent of the rocks) formed with the plagioclase and therefore also predate the hydrous minerals. Hornblende, biotite, and sphene display euhedral faces against each other and interstitial quartz or K-feldspar (fig. $4 A, F$ ), but they only rarely are euhedral against plagioclase. These relations indicate that at least the outer parts of the hydrous mineral grains are coeval with the interstitial quartz and $\mathbf{K}$ feldspar and postdate main-stage growth of plagioclase and some quartz and $\mathrm{K}$-feldspar but do not rule out the possibility that the cores of the grains began forming during plagioclase growth. Rare small inclusions of apatite, biotite, and hornblende in the early plagioclase might suggest the second possibility but might also be interpreted to be replacement features associated with fractures and crystal dislocations lo- 
cated outside of the thin sections. Alternatively, rather than indicating favorable conditions for hydrous minerals throughout the magma, the small inclusions might have resulted from local concentrations of the required components that were rejected by the growing anhydrous plagioclase.

Although these petrographic relations suggest that the hydrous minerals may have formed earlier in some magmas or parts of magmas than in others, textural relations indicate that these minerals continued to form late during crystallization in both sample groups. Some hornblende and biotite in the first sample group include aplitic groundmass material in their edges (fig. $3 A, B)$ and some in their centers, indicating, as does the presence of hydrous minerals in the groundmass (fig. $3 C$ ), that at least part of the growth of the hydrous minerals accompanied crystallization of the groundmass. In the samples of the second group, the hydrous minerals show crosscutting, interstitial, and coeval relations with the interstitial anhydrous minerals (fig. $4 B, C$ ) and replace the early-formed plagioclase (fig. $4 D$ ) and, in the more mafic samples, also pyroxene (fig. $4 E$ ). These relations and the presence of biotite, apatite, and sphene in the late-stage aplitic differentiates of all the stocks indicate that hydrous phases continued to form until only a small amount of liquid remained. All the hydrous minerals become less abundant with increasing differentiation index of the sample (fig. 5), and the modal amount of a given hydrous mineral is not detectably different when samples of like whole-rock composition from the two sample groups are compared.

Paragenetic relations between the different hydrous phases appear to vary somewhat with rock chemistry. In the more mafic samples, at least part of the hornblende appears intergrown with biotite, whereas in the more felsic Granite Mountain Porphyry, the hornblende occurs only as very rare needles (for example, sample GM18, tables 1,5) in quartz that may predate biotite. Sphene in the mafic samples is interstitial to hornblende and biotite but in more felsic rocks appears coeval with these minerals (fig. $4 F$ ). For the most part, however, the frequency of mutual inclusion, intergrowth, replacement, and proximity coupled with similar physical relations with precursor and coeval anhydrous phases indicate that the formation of biotite, hornblende, apatite, and sphene was largely coeval (figs. $3 D, H ; 4 D-F$ ). Rare grains of interstitial epidote thought to be igneous or to be replaced interstitial glass are the exception and appear always to postdate the other hydrous phases, except perhaps sphene in the mafic samples. The epidote is sometimes chemically distinguishable from epidote formed at the expense of biotite and plagioclase in the same thin section, and igneous minerals in contact with it appear unaltered (fig. $4 G, H$ ). Compared to the other hydrous minerals, apatite is commonly euhedral (fig. $4 D, E ; 3 H$ ) and seems not to include apparently coeval hydrous, anhydrous silicate (it does include zircon and opaque minerals) or even plagioclase in occurrences where it appears to replace that mineral.

Crystal growth relations of the interstitial hydrous minerals, quartz, and K-feldspar appear to be complex. A given hydrous mineral grain may have a euhedral face in contact with an interstitial grain of a given anhydrous mineral, whereas the other face or other grain of the hydrous mineral in the same or different thin section of the same pluton may replace the $K$-feldspar and quartz or be intergrown with them (fig. $4 A$ ). The same relations occur between different hydrous minerals and also between interstitial quartz and $K$-feldspar. Also, replacement and overgrowth features occur between like-mineral grains. These relations indicate that the conditions governing mineral stabilities fluctuated repeatedly over short distances during formation of the interstitial material. They may also suggest equilibrium crystallization where continual reconstitution of the crucial components for growth of a given phase (among them $\mathrm{Cl}, \mathrm{F}$ and $\mathrm{H}_{2} \mathrm{O}$ ) was caused by rejection of the components by other nearby phases.

\section{ANALYTICAL RESULTS}

\section{Methods}

The mineral analyses were done with an ARL (Applied Research Lab.) model EMX-SM electron microprobe using an ADP crystal for $\mathrm{Cl}$ and an RAP crystal for $\mathrm{F}$, an excitation voltage of $15 \mathrm{kV}$, sample currents of $2.5 \times 10^{-8}$ or $3 \times 10^{-8} \mathrm{~A}$ on brass, integration times (terminated on a fixed beam current) of about $40 \mathrm{~s}$, and scapolite (2.57 wt percent $\mathrm{Cl}$ ) and fluorapatite (3.83 wt percent $F$ ) as standards. The electron beam was fully focused. Buildup of carbon contamination and noticeable loss of volatile components were avoided by moving the beam with magnetic deflectors to sweep areas about 4-10 $\mu \mathrm{m}^{2}$. At the termination of each counting interval, the sample was moved under the beam about $1 \mu \mathrm{m}$. If the grain shape and size did not allow this type of analysis, the sample was moved manually under a fully focused or defocused $(2-3 \mu \mathrm{m})$ beam about every $10 \mathrm{~s}$. The X-ray intensity data (counts), obtained by averaging 4-10 (usually 8) observations per analysis, were corrected by computer. Except for apatite, observation points were distributed over an area of about $10 \times 10 \mu \mathrm{m}$. Data collection for apatite was similar to the above except that the data points 

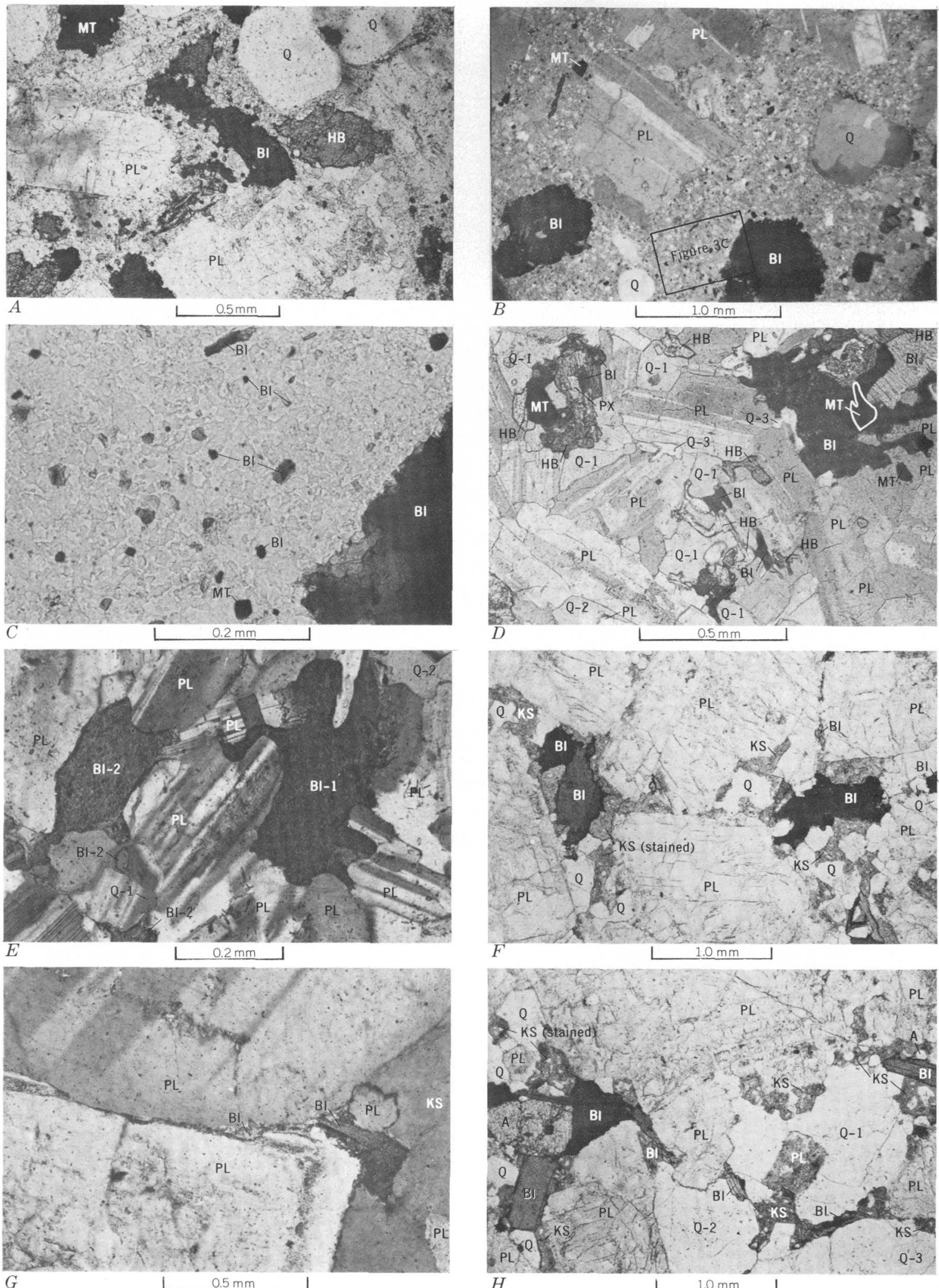

were distributed in two ways: (1) Equal numbers at centers and edges of the grain, or (2) as steps across a grain. Computer corrections included drift, back-

ground, and matrix corrections (mass absorption, secondary fluorescence, and atomic number effects: Beeson, 1967; Beaman and Isasi, 1970). Major-element 
data used in the computer corrections were gathered during 6-15 counting intervals (of about $20 \mathrm{~s}$ each) using (where appropriate) biotite, apatite, rhodonite, hornblende, rutile, hematite, orthoclase and plagioclase as standards.

Precision of the microprobe analyses is considered to be about \pm 10 percent of the amount present for $F$ and slightly better for $\mathrm{Cl}$. Detection levels were established at three times the square root of the background counts (Birks, 1963). The average $\mathrm{Cl}$ and $\mathrm{F}$ contents of biotite in one sample determined by microprobe analysis agree within 17 percent of the amount determined by wet-chemical analysis (sample 261-25, table 4). This is good agreement considering the inhomogeneity of this sample with respect to $\mathrm{Cl}$ and $\mathrm{F}$ and considering the correction factors involved in using scapolite and apatite for $\mathrm{Cl}$ and $\mathrm{F}$ analysis of biotite. The values of $\mathrm{H}_{2} \mathrm{O}+$ reported in tables 2-6 are calculated by difference by assuming ideality for each mineral phase and using the computer program of Jackson and others (1967) to obtain the required normalizing factors. The $\mathrm{H}_{2} \mathrm{O}+$ data are less precise than the $\mathrm{Cl}$ and $\mathrm{F}$ data because the precision of the normalizing factor is influenced by sample homogeneity of six to nine elements rather than one. This and the variation in the majorelement contents between mineral grains resulted in different calculated $\mathrm{H}_{2} \mathrm{O}+$ contents for some of the mineral grains in tables 3-6, although the grains have similar $\mathrm{Cl}$ and $\mathrm{F}$ contents. The $\mathrm{H}_{2} \mathrm{O}+$ content, by analysis, of one biotite (grain CHEM, sample 261-25,

Figure 3.-Textural relations of minerals in Laramide rocks at Ray, Ariz. (A, apatite; BI, biotite; KS, K-feldspar; HB, hornblende; MT, magnetite; PL, plagioclase; $Q$, quartz. Numbers indicate different outcrops of individual, optically continuous grains.) A, Sample 60-114, porphyritic facies of Rattler Granodiorite. Phenocrysts of euhedral to subhedral plagioclase, subhedral to anhedral quartz and magnetite, and anhedral biotite and hornblende in groundmass of plagioclase, K-feldspar, quartz, and biotite. $B$, Sample 6125, porphyritic facies of Rattler Granodiorite. Phenocrysts of subhedral to euhedral plagioclase, biotite, hornblende (not shown), and magnetite and rounded quartz in groundmass of plagioclase, K-feldspar, biotite, and magnetite. $C$, Inset of figure $3 B$ showing biotite in groundmass. $D$, Sample 17-28, Tortilla Quartz Diorite. Subhedral plagioclase with interstitial hornblende, biotite, and quartz. $E$, Sample 17-28, Tortilla Quartz Diorite. Detail of interstitial biotite and quartz. $F$, Sample 60-131, seriate porphyritic facies of Rattler Granodiorite. Quartz, K-feldspar (stained) and blotite interstitial to euhedral to subhedral plagioclase. $G$, Sample RB-5, Granite Mountain Porphyry. Euhedral plagioclase with biotite and interstitial oikocrystic K-feldspar (stained). $H$, Sample 60-131, seriate porphyritic facies of Rattler Granodiorite. Euhedral apatite and anhedral biotite, quartz, and K-feldspar (stained) interstitial to euhedral to subhedral plagioclase. table 4) is lower than that obtained by calculation and thus also is less than that required for ideality. It is not known whether this is real or resulted from excessively high temperatures used in drying the separate.

Supplementary analyses of whole-rock $\mathrm{Cl}, \mathrm{F}$, and $\mathrm{H}_{2} \mathrm{O}+$ were done by wet-chemical methods. The $\mathrm{Cl}$ and $\mathrm{F}$ analyses were done on dry-rock powders and their water-leached splits. The water leaching removes $\mathrm{Cl}$ contributed by salts precipitated on fractures by ground water. The modal data were determined by combined observations of thin sections and stained rock slabs so that the effects of porphyritic texture and large grain size were minimized.

\section{Comparative $\mathrm{Cl}, \mathrm{F}$, and $\mathrm{H}_{2} \mathrm{O}+$ contents of the minerals}

The $\mathrm{Cl}, \mathrm{F}$, and $\mathrm{H}_{2} \mathrm{O}+$ contents of the minerals are summarized in table 2 and presented separately in tables 3-9. Cl and $\mathrm{F}$ generally show a preference for apatite over coexisting biotite, hornblende, sphene, and epidote (see also Stormer and Carmichael, 1971), whereas $\mathrm{H}_{2} \mathrm{O}+$ shows a preference for the silicates over apatite. $\mathrm{F}$ is dominant over $\mathrm{Cl}$ in all the igneous minerals (see also Stormer and Carmichael, 1971, and Taborszky, 1962).

Biotite contains more $\mathrm{H}_{2} \mathrm{O}+$ and $\mathrm{F}$, and usually more $\mathrm{Cl}$ by weight than coexisting hornblende, sphene, and interstitial epidote. Correns (1956) and Gillberg (1964) found similar relations between the halogen contents of cnexisting biotite and hornblende, and the data of Dodge and others $(1968,1969)$ for rocks of the Sierra Nevada batholith and Dodge and Ross (1971) for granitic rocks in the Coast and Transverse Ranges, Calif., show that coexisting biotite contains more $\mathrm{H}_{2} \mathrm{O}+$ and $\mathrm{F}$ by weight and slightly less or the same amount of $\mathrm{Cl}$ than coexisting hornblende. Hornblende, like biotite, generally contains more $\mathrm{Cl}, \mathrm{F}$, and $\mathrm{H}_{2} \mathrm{O}+$ by weight than coexisting sphene, whereas sphene contains less $\mathrm{H}_{2} \mathrm{O}+$ and more $\mathrm{F}$ than interstitial epidote. In terms of atomic percent, biotite in a given sample contains $\mathrm{Cl}^{-}, \mathrm{F}^{-}$, and $\mathrm{OH}^{-}$in about the same relative proportions as hormblende and sphene (ranging from 0 to 2 percent for $\mathrm{Cl}^{-}$, from 2 to 14 percent for $\mathrm{F}^{-}$, and from 86 to 96 percent for $\mathrm{OH}^{-}$) but contains less $\mathrm{Cl}^{-}$and $\mathrm{F}^{-}$than apatite (ranging from 0 to 20 percent $\mathrm{Cl}^{-}, 32$ to 98 percent $\mathrm{F}^{-}$, and 2 to 48 percent $\mathrm{OH}^{-}$apatite).

Hydrothermal biotite contains significantly different amounts of $\mathrm{Cl}$ and $\mathrm{F}$ compared with igneous biotite in equivalent rocks from outside the Ray deposit (table 2; in table 4 compare T123 with samples of Granite Mountain Porphyry). In addition to differences in $\mathrm{Cl}$ and $\mathrm{F}$ contents, hydrothermal biotite from Granite 

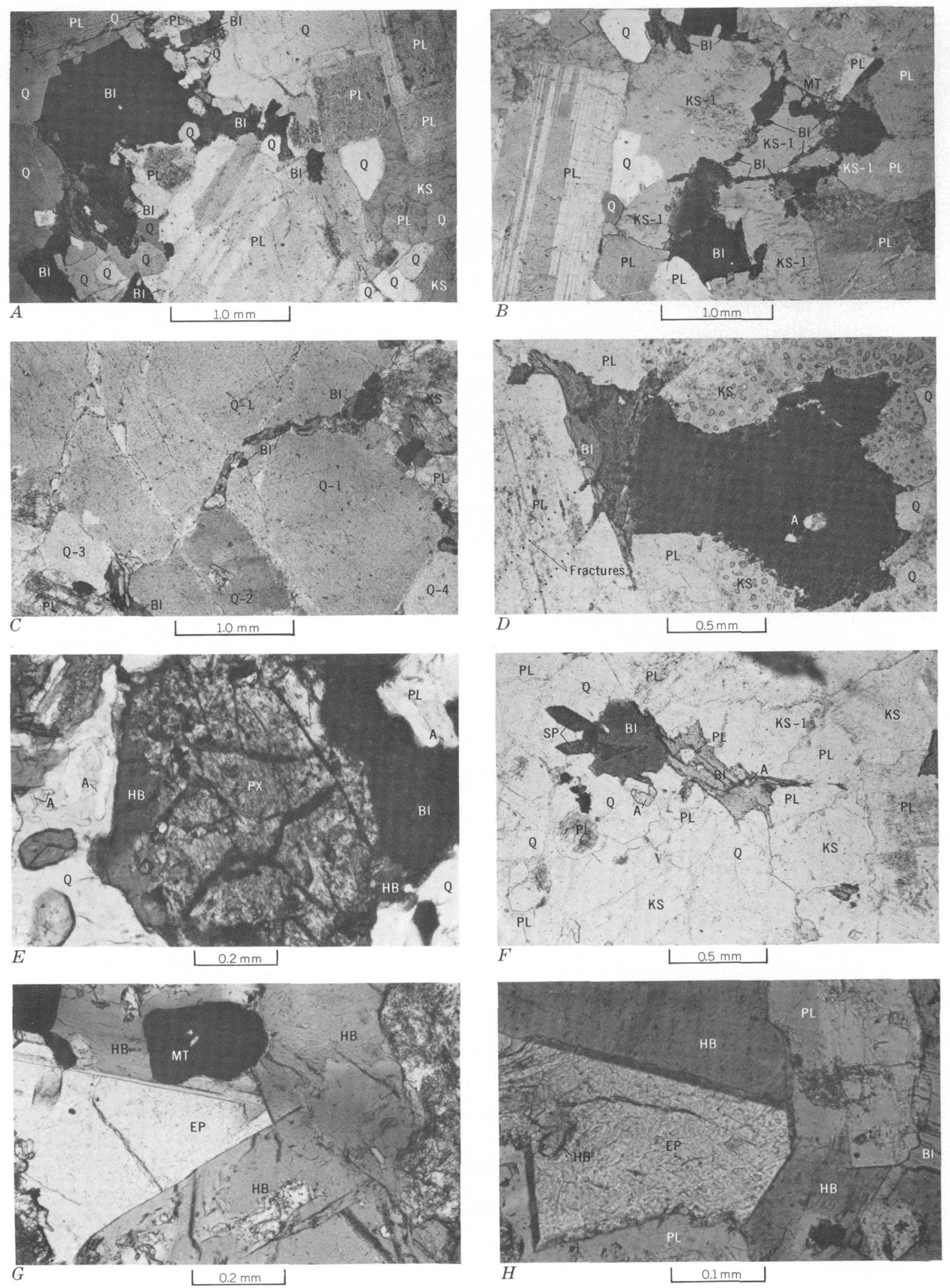

Mountain Porphyry differs from igneous biotite by containing more $\mathrm{Mg}$ (66 versus 55 mole fraction

phlogopite). Roegge and others (1974) found approximately the same amount of $\mathrm{Cl}(0.07-0.09$ wt percent) 
as that of sample T123 in another sample of hydrothermal biotite from the Granite Mountain Porphyry at Ray.

The $\mathrm{F}$ content of the chlorite in the Laramide rocks correlates with greater than 99-percent confidence with the F content of its biotite precursor. Similarly, both biotite and its derivative chlorite in the Ruin Granite contain more $\mathrm{F}$ than the biotite and chlorite in the Laramide rocks (table 2). Positive correlations also were found between the contents of the major and other minor elements in the chlorites and their precursor biotites from the Laramide rocks (Banks, 1974). There is no correlation between the contents of $F$ in the epidote, sphene, and hydrogarnet(?) analyzed and the content of $\mathrm{F}$ in the host biotite.

Analyses of four phengites are given in table 8, although the results are not summarized in table 2. Two are alteration products of plagioclase, and two are alteration products of chlorite. Additionally, an intense-

4 Froure 4.-Textural relations of minerals in Laramide rocks at Ray, Ariz. (A, apatite; BI, biotite ; EP, epidote; HB, hornblende; KS, K-feldspar; MT, magnetite; PL, plagioclase; $P X$, pyroxene; SP, sphene; $Q$, quartz. Numbers indicate outcrops of individual, optically continuous grains.) $A$, Sample 60-130, hypidiomorphic-seriate facies of Rattler Granodiorite. Euhedral plagioclase, interstitial anhedral K-feldsspar, and anhedral to euhedral quartz, and biotite. Note euhedral face of biotite against quartz at left side of photograph. $B$, Sample $60-130$, same sample as $3 A$. Biotite cutting and interstitial to interstitial K-feldspar. $C$, Sample 60-132, hypidiomorphic-seriate facies of Rattler Granodiorite. Biotite cutting oikocrystic quartz. $D$, Sample RB5, Granite Mountain Porphyry. Biotite and K-feldspar (stained) interstitial to and replacing plagioclase. Apatite in biotite. $E$, Sample 17-28, Tortilla Quartz Diorite. Biotite and hornblende rimming pyroxene. Apatite in interstitial quartz. $F$, Sample, RB5, Granite Mountain Porphyry. Sphene, apatite, and biotite with interstitial quartz and K-feldspar. $G, H$, Sample 48-29, Tortilla Quartz Diorite. Epidote interstitial to unaltered hornblende and plagioclase. ly altered area of plagioclase (2GM14, grain 4SPA) containing unidentified fine-grained clay minerals, too
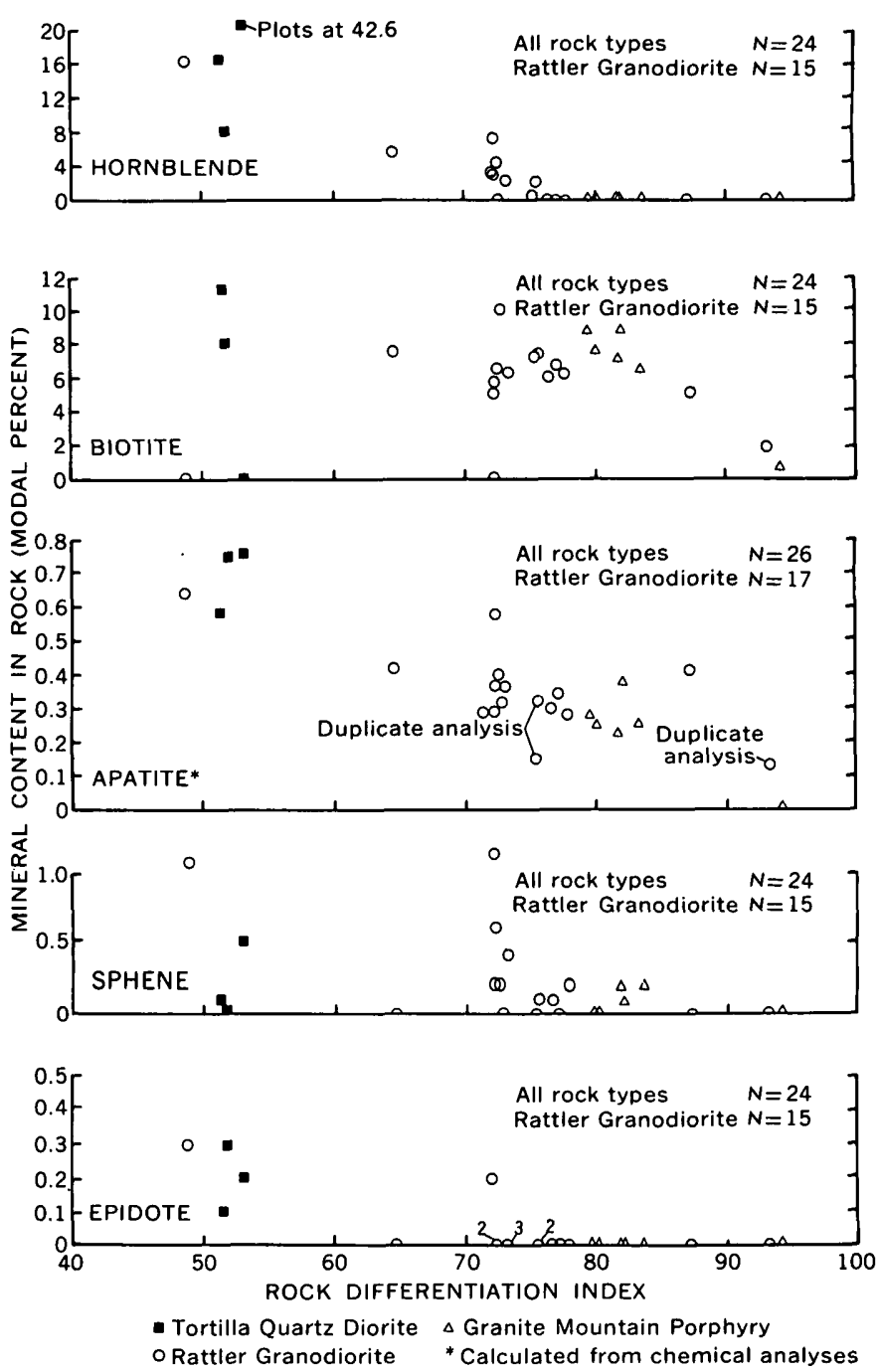

Figure 5.-Variation of mineral modal abundance with rock differentiation index.

TABLE 2.-Ranges of $\mathrm{Cl}, \mathrm{F}$, and $\mathrm{H}_{2} \mathrm{O}+$ contents in the hydrous minerals

\begin{tabular}{|c|c|c|c|c|c|c|c|c|c|c|}
\hline & \multicolumn{5}{|c|}{ Igneous minerals } & \multicolumn{5}{|c|}{ Alteration minerals } \\
\hline & Apatite & Biotite & Hornblende & Sphene & Epidote & Chlorite & Sphene & Epidote & $\begin{array}{l}\text { Hydro- } \\
\text { garnet? }\end{array}$ & $\begin{array}{c}\text { Hydro- } \\
\text { thermal } \\
\text { biotite }\end{array}$ \\
\hline \multicolumn{11}{|l|}{ Laramide rocks : } \\
\hline Cl & $0.02-1.4$ & $0.02-0.26$ & $0.02-0.17$ & $<0.02-0.02$ & $<0.02$ & $<0.02-0.04$ & & $<0.02$ & $<0.02$ & 0.06 \\
\hline $\mathbf{F}$ & $1.2-3.6$ & $.10-0.86$ & $.11-0.58$ & $.08-.30$ & $<.04$ & $<.04-.30$ & $0.18-2.5$ & $<.04-0.11$ & $.60-1.8$ & 1.7 \\
\hline${ }^{*} \mathrm{H}_{2} \mathrm{O}+$ & $.06-1.09$ & $3.52-3.94$ & $1.76-2.00$ & $\dagger .99-1.12$ & $1.86-1.88$ & $.04-.30$ & ----- & $----1-2-$ & -- - & 3.22 \\
\hline \multicolumn{11}{|l|}{ Ruin Granite: } \\
\hline $\mathrm{Cl}$ & .11 & $.10-0.13$ & ------ & -------- & --------- & $<.02$ & $---\cdots$ & - - & - - - - - & $----\infty$ \\
\hline $\mathbf{F}-----$ & 3.3 & $1.7-1.8$ & ------ & -------- & -------- & $.37-.44$ & ----- & 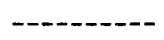 & ----- & $----\cdots$ \\
\hline$\stackrel{*}{*} \mathrm{H}_{2} \mathrm{O}+-$ & ----- & ----- & ------ & $-------\infty$ & ---------- & -------- & ------ & ---------- & ------- & $-\cdots-\cdots$ \\
\hline \multicolumn{11}{|c|}{ Precambrian diabase : } \\
\hline F & 2.1 & $<.04$ & $---1--$ & - & --_---- & 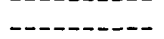 & $---n-$ & $---1----$ & 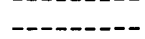 & 1.4 \\
\hline$* \mathrm{H}_{2} \mathrm{O}+\ldots$ & ------ & ------- & ----- & -------- & ---------- & -------- & ----- & --------- & ------- & $.3 .42-3.43$ \\
\hline
\end{tabular}

* Calculated by difference assuming ideal [Cl, F, OH]

† Calculated assuming all $\mathrm{O}_{1}$ oxygen sites occupied by $\mathrm{Cl}, \mathrm{F}$, and $\mathrm{OH}$ 
TABLE 3.- $\mathrm{Cl}, \mathrm{F}$, and $\mathrm{H}_{2} \mathrm{O}+$ contents in igneous apatite from Laramide intrusive rocks near the Ray porphyry copper deposit, Arizona

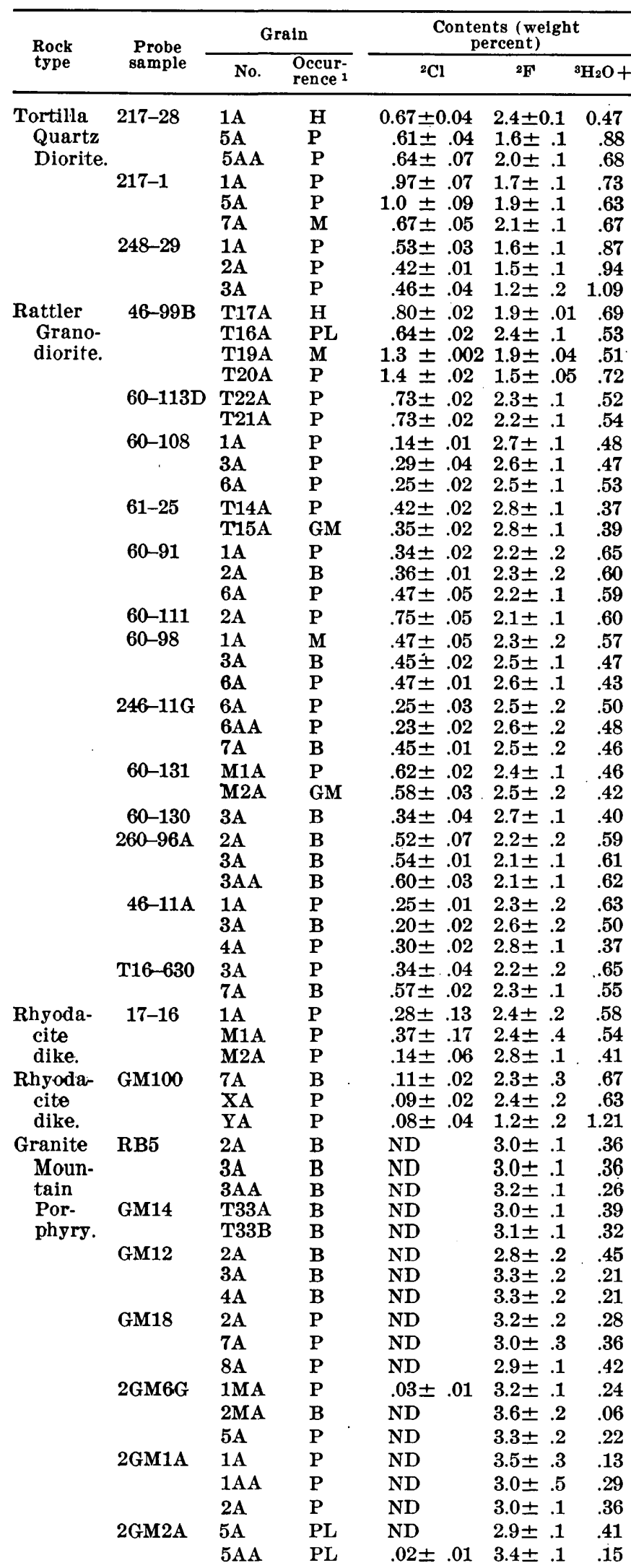

TABLE 3.- $\mathrm{Cl}, \mathrm{F}$, and $\mathrm{H}_{2} \mathrm{O}+$ contents in igneous apatite from Laramide intrusive rocks near the Ray porphyry copper deposit, Arizona-Continued

\begin{tabular}{|c|c|c|c|c|c|c|}
\hline \multirow{2}{*}{$\begin{array}{l}\text { Rock } \\
\text { type }\end{array}$} & \multirow{2}{*}{$\begin{array}{l}\text { Probe } \\
\text { sample }\end{array}$} & \multicolumn{2}{|c|}{ Grain } & \multicolumn{3}{|c|}{$\begin{array}{l}\text { Contents (weight } \\
\text { percent) }\end{array}$} \\
\hline & & No. & $\begin{array}{l}\text { Occur- } \\
\text { rence }{ }^{1}\end{array}$ & ${ }^{2} \mathrm{Cl}$ & $2 \mathbf{F}$ & ${ }^{3} \mathrm{H}_{2} \mathrm{O}+$ \\
\hline Teapot & 2TTM & $1 \mathrm{~A}$ & B & $.13 \pm .02$ & $2.6 \pm .2$ & .51 \\
\hline Moun- & & $2 A$ & GM & $.09 \pm .02$ & $3.3 \pm .1$ & .20 \\
\hline tain & & $\mathbf{5 A}$ & B & $.12 \pm .01$ & $2.6 \pm .2$ & .53 \\
\hline $\begin{array}{l}\text { Por- } \\
\text { phyry. }\end{array}$ & & $\mathbf{5 A A}$ & $\mathbf{G M}$ & $.11 \pm .01$ & $2.8 \pm .1$ & .42 \\
\hline $\begin{array}{l}\text { Rhyoda- } \\
\text { cite } \\
\text { dike. }\end{array}$ & $61-2 F$ & $\begin{array}{l}\text { T18A } \\
\text { T10A }\end{array}$ & $\begin{array}{l}\mathbf{G M} \\
\mathbf{P}\end{array}$ & $\begin{array}{l}.77 \pm .03 \\
.16 \pm .02\end{array}$ & $\begin{array}{l}1.4 \pm .1 \\
1.7 \pm .1\end{array}$ & $\begin{array}{l}.91 \\
.92\end{array}$ \\
\hline
\end{tabular}

${ }^{1}$ Grain occurrence: $P$, phenocryst or large grain; $H$, inclusion in hornblende; $\mathbf{B}$, inclusion in biotite; $\mathbf{M}$, inclusion in magnetite; $\mathbf{P l}$

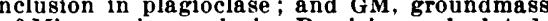
from standard counting error $\mathrm{Tr}$ mean $6 \mathrm{f}$ to 10 data points. ND, not detected at $0.02 \mathrm{wt}$ 3 Calculated assuming ideal $[\mathrm{Cl}, \mathrm{F}, \mathrm{OH}]$.

TABLE 4-Cl, F, and $\mathrm{H}_{2} \mathrm{O}+$ contents in Laramide igneous and hydrothermal biotite in and near the Ray porphyry copper deposit, Arizona.

\begin{tabular}{|c|c|c|c|c|c|}
\hline \multirow{2}{*}{$\begin{array}{c}\text { Rock } \\
\text { type }\end{array}$} & \multirow{2}{*}{$\begin{array}{c}\text { Probe } \\
\text { sample }\end{array}$} & \multirow{2}{*}{$\begin{array}{c}\text { Grain } \\
\text { No. }\end{array}$} & \multicolumn{3}{|c|}{$\begin{array}{c}\text { Contents }{ }^{1} \text { (weight } \\
\text { percent) }\end{array}$} \\
\hline & & & ${ }^{2} \mathrm{Cl}$ & $2 \mathrm{~F}$ & $\mathrm{I}_{2} \mathrm{O}+$ \\
\hline \multirow{9}{*}{$\begin{array}{l}\text { Tortilla } \\
\text { Quartz } \\
\text { Diorite. }\end{array}$} & \multirow[t]{4}{*}{ 217-28 } & $2 \mathrm{BIC}$ & $0.13 \pm 0.01$ & $0.27 \pm 0.01$ & 3.87 \\
\hline & & 2BIE & $.14 \pm .01$ & $.26 \pm .01$ & 3.8 \\
\hline & & $5 \mathrm{BIC}$ & $.15 \pm .01$ & $.26 \pm .03$ & 3.80 \\
\hline & & 5BIE & $.13 \pm .02$ & $.25 \pm .05$ & 3.81 \\
\hline & \multirow[t]{5}{*}{ 217-1 } & 1BIC & $.15 \pm .02$ & $.14 \pm .03$ & 3.8 \\
\hline & & 1BIE & $.15 \pm .02$ & $.16 \pm .02$ & 3.8 \\
\hline & & 5BI & $.17 \pm .01$ & $.19 \pm .04$ & 3.8 \\
\hline & & 4BIC & $.12 \pm .02$ & $.23 \pm .02$ & 3.8 \\
\hline & & 4BIE & $.14 \pm .01$ & $.20 \pm .03$ & 3.9 \\
\hline \multirow{30}{*}{$\begin{array}{l}\text { Rattler } \\
\text { Granodiorite. }\end{array}$} & 246-99B & *3BIC & $.18 \pm .003$ & $.27 \pm .04$ & 3.8 \\
\hline & & *3BIE & $.19 \pm .003$ & $.30 \pm .06$ & 3.7 \\
\hline & \multirow[t]{3}{*}{ 260-113D } & 3BIC & $.23 \pm .01$ & $.34 \pm .05$ & 3.7 \\
\hline & & 3BIE & $.26 \pm .03$ & $.41 \pm .04$ & 3.7 \\
\hline & & $* 4 \mathrm{BI}$ & $.23 \pm .01$ & $.37 \pm .02$ & 3.7 \\
\hline & \multirow[t]{4}{*}{$261-25$} & 1BIC & $.15 \pm .004$ & $.46 \pm .03$ & 3.7 \\
\hline & & 1BIE & $.14 \pm .003$ & $.47 \pm .09$ & 3.7 \\
\hline & & 3BIC & $.14 \pm .003$ & $.54 \pm .05$ & 3.6 \\
\hline & & CHEM & 4.12 & ${ }^{5} .42$ & 3.3 \\
\hline & \multirow[t]{6}{*}{$60-91$} & 2BIC & $.13 \pm .01$ & $.34 \pm .03$ & 3.8 \\
\hline & & 2BIE & $.12 \pm .01$ & $.29 \pm .02$ & 3.8 \\
\hline & & $4 \mathrm{BIC}$ & $.12 \pm .01$ & $.32 \pm .03$ & 3.8 \\
\hline & & 4BIE & $.10 \pm .01$ & $.31 \pm .05$ & 3.8 \\
\hline & & $5 \mathrm{BIC}$ & $.13 \pm .01$ & $.31 \pm .04$ & 3.8 \\
\hline & & 5BIE & $.12 \pm .01$ & $.36 \pm .05$ & 3.8 \\
\hline & \multirow[t]{5}{*}{$60-111$} & $2 \mathrm{BI} 1 \mathrm{C}$ & $.18 \pm .01$ & $.39 \pm .03$ & 3.8 \\
\hline & & 2BI1E & $.19 \pm .01$ & $.41 \pm .04$ & 3.8 \\
\hline & & 2BI2C & $.20 \pm .02$ & $.40 \pm .03$ & 3.7 \\
\hline & & 2BI2E & $.19 \pm .01$ & $.36 \pm .03$ & 3.8 \\
\hline & & 1BIC & $.17 \pm .01$ & $.37 \pm .05$ & 3.8 \\
\hline & \multirow[t]{4}{*}{$246-11 G$} & 3BIC & $.12 \pm .01$ & $.49 \pm .03$ & 3.7 \\
\hline & & 3BIE & $.14 \pm .01$ & $.46 \pm .04$ & 3.7 \\
\hline & & 4BIC & $.13 \pm .01$ & $.48 \pm .05$ & 3.7 \\
\hline & & 4BIE & $.11 \pm .01$ & $.50 \pm .06$ & 3.7 \\
\hline & \multirow[t]{6}{*}{$60-131$} & $1 B I C$ & $.13 \pm .01$ & $.38 \pm .03$ & 3.78 \\
\hline & & 1BIE & $.13 \pm .01$ & $.35 \pm .03$ & 3.8 \\
\hline & & 2BIC & $.12 \pm .01$ & $.40 \pm .03$ & 3.8 \\
\hline & & 2BIE & $.11 \pm .01$ & $.38 \pm .04$ & 3.8 \\
\hline & & 3BI & $.14 \pm .01$ & $.43 \pm .02$ & 3.7 \\
\hline & & $4 \mathrm{BIC}$ & $.13 \pm .01$ & $.45 \pm .03$ & 3.8 \\
\hline
\end{tabular}


TABLE 4.- $\mathrm{Cl}, \mathrm{F}$, and $\mathrm{H}_{2} \mathrm{O}+$ contents in Laramide igneous and hydrothermal biotite in and near the Ray porphyry cnpper deposit, Arizona-Continued

\begin{tabular}{|c|c|c|c|c|c|}
\hline \multirow{2}{*}{$\underset{\text { type }}{\text { Rock }}$} & \multirow{2}{*}{$\begin{array}{c}\text { Probe } \\
\text { sample }\end{array}$} & \multirow{2}{*}{$\begin{array}{l}\text { Grain } \\
\text { No. }\end{array}$} & \multicolumn{3}{|c|}{$\begin{array}{l}\text { Contents }{ }^{1} \text { (weight } \\
\text { percent) }\end{array}$} \\
\hline & & & ${ }^{2} \mathrm{Cl}$ & ${ }^{2} \mathrm{~F}$ & $\mathrm{H}_{2} \mathrm{OH}$ \\
\hline \multirow{13}{*}{$\begin{array}{l}\text { Rattler Grano } \\
\text { diorite-Con }\end{array}$} & & 4BIE & $.14 \pm .01$ & $.42 \pm .05$ & 3.80 \\
\hline & $60-130$ & $\begin{array}{l}5 \mathrm{BI} \\
2 \mathrm{BI}\end{array}$ & $\begin{array}{l}.18 \pm .01 \\
16+.01\end{array}$ & $\begin{array}{r}.43 \pm .03 \\
40 \pm .03\end{array}$ & $\begin{array}{l}3.78 \\
3.79\end{array}$ \\
\hline & $260-96 A$ & 3BIC & $.15 \pm .01$ & $.45 \pm .04$ & 3.80 \\
\hline & & 3BIE & $.16 \pm .01$ & $.46 \pm .03$ & 3.78 \\
\hline & $246-11 A$ & $1 \mathrm{BIC}$ & $.14 \pm .01$ & $.60 \pm .03$ & 3.68 \\
\hline & & 1BIE & $.14 \pm .01$ & $.61 \pm .05$ & 3.66 \\
\hline & & $5 \mathrm{BIC}$ & $.16 \pm .01$ & $.62 \pm .04$ & 3.63 \\
\hline & & 5BIE & $.15 \pm .01$ & $.62 \pm .05$ & 3.63 \\
\hline & $\mathrm{T} 16-630$ & 1BI & $.10 \pm .01$ & $.31 \pm .03$ & $\left({ }^{6}\right)$ \\
\hline & & 3BI & $.11 \pm .001$ & $.28 \pm .03$ & $\left({ }^{6}\right)$ \\
\hline & & 4BI & $.11 \pm .01$ & $.34 \pm .04$ & $\left({ }^{6}\right)$ \\
\hline & & $5 \mathrm{BI}$ & $.10 \pm .01$ & $.29 \pm .03$ & $\left({ }^{8}\right)$ \\
\hline & & 9BI & $.12 \pm .01$ & $.36 \pm .05$ & $\left({ }^{\circ}\right)$ \\
\hline \multirow{5}{*}{$\begin{array}{l}\text { Rhyodacite } \\
\text { dike. }\end{array}$} & 2GM100 & $1 \mathrm{BIC}$ & $.15 \pm .004$ & $.16 \pm .03$ & 3.81 \\
\hline & & 1BIE & $.09 \pm .01$ & $.25 \pm .01$ & 3.79 \\
\hline & & 3BIC & $.07 \pm .003$ & $.20 \pm .04$ & 3.85 \\
\hline & & 3BIM & $.09 \pm .02$ & $.23 \pm .04$ & 3.83 \\
\hline & & 3BIE & $.06 \pm .01$ & $.25 \pm .07$ & 3.83 \\
\hline \multirow{25}{*}{$\begin{array}{l}\text { Granite } \\
\text { Mountain } \\
\text { Porphyry. }\end{array}$} & RB5 & 6BIC & $.04 \pm .02$ & $.56 \pm .03$ & 3.67 \\
\hline & & 6BI1E & $.05 \pm .01$ & $.50 \pm .02$ & 3.69 \\
\hline & & 6BI2E & $.04 \pm .002$ & $.52 \pm .03$ & 3.68 \\
\hline & & $7 \mathrm{BIC}$ & $.04 \pm .01$ & $.58 \pm .06$ & 3.65 \\
\hline & & 7BIE & $.03 \pm .01$ & $.59 \pm .03$ & 3.67 \\
\hline & 2GM14 & 2BI & $.02 \pm .01$ & $.67 \pm .07$ & 3.61 \\
\hline & & 2BIA & $.02 \pm .01$ & $.61 \pm .04$ & 3.67 \\
\hline & & 6BI & $.02 \pm .01$ & $.63 \pm .04$ & 3.59 \\
\hline & GM12 & 4BI & $.05 \pm .01$ & $.61 \pm .07$ & 3.64 \\
\hline & & $2 \mathrm{BI}$ & $.03 \pm .01$ & $.69 \pm .05$ & 3.61 \\
\hline & & 3BI & $.05 \pm .01$ & $.61 \pm .05$ & 3.63 \\
\hline & & 3BIA & $.02 \pm .01$ & $.63 \pm .03$ & 3.65 \\
\hline & GM18 & MBIC & $.04 \pm .01$ & $.75 \pm .05$ & 3.59 \\
\hline & & MBIE & $.04 \pm .003$ & $.72 \pm .05$ & 3.61 \\
\hline & & M1BIC & $.03 \pm .01$ & $.82 \pm .05$ & 3.57 \\
\hline & & M1BIE & $.02 \pm .004$ & $.81 \pm .04$ & 3.62 \\
\hline & & M2BIC & $.03 \pm .01$ & $.62 \pm .06$ & 3.66 \\
\hline & & M2BIE & $.04 \pm .01$ & $.54 \pm .12$ & 3.70 \\
\hline & GM6G & 3BIA & $.02 \pm .006$ & $.66 \pm .06$ & 3.58 \\
\hline & & 4BIA & $.03 \pm .006$ & $.69 \pm .04$ & 3.60 \\
\hline & 2GM6G & 4BI & $.03 \pm .01$ & $.76 \pm .13$ & 3.52 \\
\hline & 2GM4V & 1BIA & $.02 \pm .004$ & $.77 \pm .06$ & 3.59 \\
\hline & & 3BIA & $.03 \pm .006$ & $.86 \pm .04$ & 3.58 \\
\hline & & 3BIB & $.04 \pm .01$ & $.82 \pm .05$ & 3.55 \\
\hline & GM2A & $1 \mathrm{BI}$ & $.02 \pm .01$ & $.72 \pm .18$ & 3.60 \\
\hline \multirow{2}{*}{$\begin{array}{c}\text { Mineralized } \\
\text { diabase. }\end{array}$} & P70-22 & 1BI & $.05 \pm .02$ & $1.4 \pm .1$ & 3.43 \\
\hline & & 1BIA & $.09 \pm .03$ & $1.4 \pm .2$ & 3.42 \\
\hline \multirow{4}{*}{$\begin{array}{c}\text { Mineralized } \\
\text { Granite } \\
\text { Mountain } \\
\text { Porphyry. }\end{array}$} & T123 & BI1 & $.06 \pm .005$ & $1.7 \pm .1$ & 3.22 \\
\hline & & BI2 & $.06 \pm .003$ & $1.7 \pm .1$ & 3.22 \\
\hline & & & & & \\
\hline & & & & & \\
\hline
\end{tabular}

* Inclusion in hornblende.

1 Precision calculated from standard counting error from the mean of 5 to 10 data points collected within a $10 \times 10 \mu \mathrm{m}$ area.

2 Microprobe analysis.

3 Calculated assuming ideal $[\mathrm{Cl}, \mathrm{F}, \mathrm{OH}]$

$4 \mathrm{Cl}$ by chemical analysis; J. Budinsky, analyst.

$\mathrm{F}$ and $\mathrm{H}_{2} \mathrm{O}+$ by chemical analysis ; $\mathrm{M}$. Cremer, analyst.

- Incomplete analysis; $\mathrm{H}_{2} \mathrm{O}$ + was not calculated.
TABLE 5-Cl, F, and $\mathrm{H}^{2} \mathrm{O}+$ contents in hornblende from Lara mide intrusive rocks near the Ray porphyry copper deposit, Arizona

\begin{tabular}{|c|c|c|c|c|c|}
\hline $\begin{array}{c}\begin{array}{c}\text { Rock } \\
\text { type }\end{array} \\
\end{array}$ & $\begin{array}{l}\text { Probe } \\
\text { sample }\end{array}$ & $\underset{\text { Go. }}{\text { Grain }}$ & \multicolumn{3}{|c|}{ Contents $^{1}$ (weight percent) } \\
\hline \multirow{8}{*}{$\begin{array}{l}\text { Tortilla } \\
\text { Quartz } \\
\text { Diorite. }\end{array}$} & $217-28$ & $2 \mathrm{H}$ & $0.08 \pm 0.007$ & $0.16 \pm 0.03$ & 1.92 \\
\hline & & $\mathbf{3 H}$ & $.07 \pm .007$ & $.16 \pm .02$ & 1.94 \\
\hline & & $4 \mathrm{H}$ & $.09 \pm .012$ & $.13 \pm .04$ & 1.94 \\
\hline & & $4 \mathrm{HA}$ & $.07 \pm .007$ & $.11 \pm .06$ & 1.95 \\
\hline & $248-29$ & $1 \mathrm{H}$ & $.02 \pm .004$ & $.12 \pm .03$ & 1.96 \\
\hline & & $2 \mathrm{HC}$ & $.03 \pm .009$ & $.14 \pm .03$ & 1.99 \\
\hline & & $2 \mathrm{HE}$ & $.02 \pm .005$ & $.14 \pm .02$ & 2.00 \\
\hline & & $\mathbf{3 H}$ & $.03 \pm .004$ & $.15 \pm .03$ & 1.97 \\
\hline \multirow{36}{*}{$\begin{array}{l}\text { Rattler } \\
\text { Granodiorite }\end{array}$} & 246-99B & $1 \mathrm{HC}$ & $.10 \pm .007$ & $.19 \pm .05$ & 1.93 \\
\hline & & $1 \mathrm{HE}$ & $.07 \pm .005$ & $.17 \pm .02$ & 1.93 \\
\hline & & $2 \mathrm{H}$ & $.08 \pm .006$ & $.16 \pm .03$ & 1.94 \\
\hline & & $3 \mathrm{HC}$ & $.08 \pm .006$ & $.22 \pm .02$ & 1.91 \\
\hline & & $3 \mathrm{HM}$ & $.08 \pm .006$ & $.22 \pm .02$ & 1.91 \\
\hline & & $3 \mathrm{HE}$ & $.09 \pm .012$ & $.14 \pm .02$ & 1.98 \\
\hline & $60-113 D$ & MHC & $.09 \pm .010$ & $.24 \pm .02$ & 1.89 \\
\hline & & MHE & $.13 \pm .008$ & $.24 \pm .02$ & 1.90 \\
\hline & & M1HC & $.17 \pm .013$ & $.21 \pm .01$ & 1.87 \\
\hline & & M1HE & $.14 \pm .007$ & $.22 \pm .03$ & 1.88 \\
\hline & & M2HC & $.17 \pm .006$ & $.23 \pm .02$ & 1.85 \\
\hline & & $\mathrm{M} 2 \mathrm{HE}$ & $.12 \pm .010$ & $.23 \pm .03$ & 1.88 \\
\hline & $60-108$ & $1 \mathrm{H}$ & $.09 \pm .009$ & $.48 \pm .06$ & 1.76 \\
\hline & & $4 \mathrm{HC}$ & $.05 \pm .007$ & $.58 \pm .03$ & 1.77 \\
\hline & & $4 \mathrm{HE}$ & $.09 \pm .005$ & $.48 \pm .02$ & 1.79 \\
\hline & & $6 \mathrm{HC}$ & $.06 \pm .004$ & $.45 \pm .05$ & 1.83 \\
\hline & & $6 \mathrm{HE}$ & $.09 \pm .005$ & $.54 \pm .04$ & 1.79 \\
\hline & T16-630 & $4 \mathrm{H}$ & $.05 \pm .008$ & $.14 \pm .05$ & $\left({ }^{4}\right)$ \\
\hline & & $6 \mathrm{H}$ & $.03 \pm .007$ & $.14 \pm .03$ & $\left({ }^{4}\right)$ \\
\hline & & $8 \mathrm{H}$ & $.04 \pm .007$ & $.21 \pm .03$ & (4) \\
\hline & $261-25$ & MH & $.08 \pm .010$ & $.30 \pm .03$ & 1.84 \\
\hline & & $4 \mathbf{H}$ & $.04 \pm .013$ & $.27 \pm .02$ & 1.93 \\
\hline & & $5 \mathrm{HC}$ & $.07 \pm .002$ & $.26 \pm .01$ & 1.80 \\
\hline & & $5 \mathrm{HE}$ & $.06 \pm .002$ & $.31 \pm .01$ & 1.83 \\
\hline & $60-91$ & MH & $.10 \pm .013$ & $.21 \pm .02$ & 1.85 \\
\hline & & 4MHC & $.05 \pm .004$ & $.22 \pm .04$ & 1.93 \\
\hline & & $4 \mathrm{MHE}$ & $.05 \pm .002$ & $.18 \pm .01$ & 1.91 \\
\hline & & $1 \mathrm{MH}$ & $.03 \pm .06$ & $.22 \pm .02$ & 1.95 \\
\hline & $60-98$ & MHC & $.04 \pm .008$ & $.24 \pm .03$ & 1.86 \\
\hline & & MHE & $.04 \pm .021$ & $.24 \pm .02$ & 1.90 \\
\hline & & $1 \mathrm{MH}$ & $.05 \pm .010$ & $.27 \pm .04$ & 1.86 \\
\hline & $246-11 G$ & $3 \mathrm{H}$ & $.04 \pm .016$ & $.30 \pm .04$ & 1.89 \\
\hline & & $5 \mathrm{HC}$ & $.06 \pm .017$ & $.28 \pm .03$ & 1.91 \\
\hline & & $5 \mathrm{HE}$ & $.06 \pm .038$ & $.26 \pm .04$ & 1.93 \\
\hline & & $7 \mathrm{HC}$ & $.04 \pm .010$ & $.29 \pm .02$ & 1.91 \\
\hline & & $7 \mathrm{HE}$ & $.04 \pm .001$ & $.26 \pm .02$ & 1.93 \\
\hline \multirow{5}{*}{$\begin{array}{l}\text { Rhyodacite } \\
\text { dike. }\end{array}$} & $17-16$ & MHC & $.14 \pm .012$ & $.17 \pm .03$ & 1.87 \\
\hline & & MHE & $.15 \pm .009$ & $.17 \pm .02$ & 1.87 \\
\hline & & M1H & $.15 \pm .015$ & $.15 \pm .04$ & 1.89 \\
\hline & & $2 \mathrm{HC}$ & $.13 \pm .010$ & $.17 \pm .05$ & 1.88 \\
\hline & & $2 \mathrm{HE}$ & $.15 \pm .011$ & $.17 \pm .03$ & 1.89 \\
\hline \multirow{3}{*}{$\begin{array}{l}\text { Rhyodacite } \\
\text { dike. }\end{array}$} & GM100 & MH & $.03 \pm .005$ & $.12 \pm .03$ & 1.98 \\
\hline & & $\mathbf{M} 1 \mathbf{H}$ & $.08 \pm .024$ & $.14 \pm .02$ & 1.90 \\
\hline & & $\mathbf{M} 2 \mathrm{H}$ & $.04 \pm .010$ & $.13 \pm .03$ & 1.97 \\
\hline Granite & GM18 & T1HC & $.06 \pm .007$ & $.38 \pm .03$ & 1.79 \\
\hline Mountain & & T1HE & $.08 \pm .005$ & $.39 \pm .04$ & 1.77 \\
\hline
\end{tabular}

1 Precision for $\mathrm{Cl}$ and $\mathrm{F}$ calculated from standard counting erro from the mean of 5 to 10 data points collected within a $10 \times 10 \mu \mathrm{m}$ area.

Microprobe analysis.

3 Calculated assuming ideal [ $\mathrm{Cl}, \mathrm{F}$, OH].
+ Incomplete analysis; $\mathrm{H}_{2} \mathrm{O}+$ was not calculated. 
TABLE 6.- $\mathrm{Cl}, \mathrm{F}$, and $\mathrm{H}_{2} \mathrm{O}+$ contents in igneous (?) epidote and igneous sphene from Laramide intrusive rocks near the Ray porphyry copper deposit, Arizona

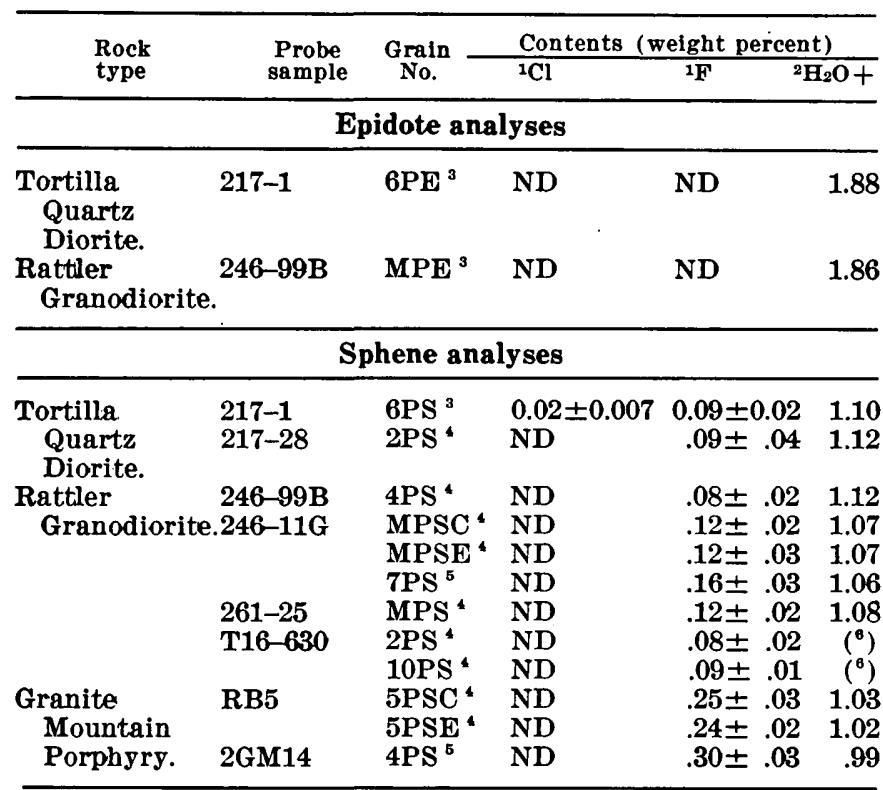

1 Microprobe analysis. Precision calculated from standard counting error from the mean of 5 to 10 data points within a $10 \times 10 \mu \mathrm{m}$ area.

ND, not detected at 0.02 wercent $F$

Phenocryst or large grain.

Incomplete analysis; $\mathrm{H}_{2} \mathrm{O}+$ not calculated.

TABLE 7.- $\mathrm{Cl}$ and $\mathrm{F}$ contents in chlorite derived from biotite in Laramide igneous rocks in and near the Ray porphyry copper deposit, Arizona

\begin{tabular}{|c|c|c|c|c|}
\hline \multirow{2}{*}{$\begin{array}{l}\text { Rock } \\
\text { type }\end{array}$} & \multirow{2}{*}{$\begin{array}{c}\text { Probe } \\
\text { sample }\end{array}$} & \multirow{2}{*}{$\begin{array}{c}\text { Grain } \\
\text { No. }\end{array}$} & \multicolumn{2}{|c|}{ Contents $^{1}$ (weight percent) } \\
\hline & & & ${ }^{2} \mathrm{Cl}$ & ${ }^{2} \mathrm{~F}$ \\
\hline $\begin{array}{l}\text { Tortilla } \\
\text { Quartz } \\
\text { Diorite. }\end{array}$ & $217-28$ & $5 \mathrm{CL}$ & ND & ND \\
\hline Rattler & 246-99B & 1CLA & ND & ND \\
\hline \multirow[t]{21}{*}{ Granodiorite } & & 1CLB & $0.03 \pm 0.012$ & $0.10 \pm 0.02$ \\
\hline & & 2CLA & ND & ND \\
\hline & & 2CLB & ND & ND \\
\hline & 260-113D & 3CLA & $.04 \pm .001$ & $.05 \pm .001$ \\
\hline & & 3CLB & $.03 \pm .004$ & $.08 \pm .02$ \\
\hline & & 4CLA & $.03 \pm .003$ & $.13 \pm .03$ \\
\hline & & 4CLB & ND & $.08 \pm .03$ \\
\hline & 261-25 & 2CLA & ND & $.07 \pm .02$ \\
\hline & & 2CLB & ND & $.16 \pm .07$ \\
\hline & 246-11G & 2CLA & ND & $.09 \pm .03$ \\
\hline & & 2CLB & ND & $.11 \pm .01$ \\
\hline & & $4 \mathrm{CL}$ & ND & $.11 \pm .001$ \\
\hline & $260-96 A$ & 3CL & ND & $.12 \pm .001$ \\
\hline & $246-11 A$ & 1CLA & $.03 \pm .007$ & $.30 \pm .04$ \\
\hline & & 1CLB & $.03 \pm .008$ & $.24 \pm .03$ \\
\hline & & 5CLA & $.02 \pm .008$ & $.15 \pm .03$ \\
\hline & & 5CLB & $.02 \pm .006$ & $.27 \pm .02$ \\
\hline & T16-630 & $1 \mathrm{CL}$ & ND & $.12 \pm .03$ \\
\hline & & $5 \mathrm{CL}$ & ND & $.09 \pm .01$ \\
\hline & & 8CL & ND & $.13 \pm .05$ \\
\hline & & 10CL & ND & $.10 \pm .04$ \\
\hline \multirow{6}{*}{$\begin{array}{l}\text { Granite } \\
\text { Mountain } \\
\text { Porphyry. }\end{array}$} & 2GM14 & $2 \mathrm{CL}$ & ND & $.12 \pm .03$ \\
\hline & & 6CL & ND & $.13 \pm .03$ \\
\hline & & 6CLA & ND & $.10 \pm .03$ \\
\hline & GM12 & 3CL & ND & $.14 \pm .02$ \\
\hline & & 3CLA & ND & $.13 \pm .02$ \\
\hline & & 4CL & ND & $.14 \pm .04$ \\
\hline
\end{tabular}

TABLE 7.-Cl and $\mathrm{F}$ contents in chlorite derived from biotite in Laramide igneous rocks in and near the Ray porphyry copper deposit, Arizona-Continued

\begin{tabular}{|c|c|c|c|c|}
\hline \multirow{2}{*}{$\begin{array}{l}\text { Rock } \\
\text { type }\end{array}$} & \multirow{2}{*}{$\begin{array}{c}\text { Probe } \\
\text { sample }\end{array}$} & \multirow{2}{*}{$\begin{array}{c}\text { Grain } \\
\text { No. }\end{array}$} & \multicolumn{2}{|c|}{ Contents ${ }^{1}$ (weight percent) } \\
\hline & & & ${ }^{2} \mathrm{Cl}$ & ${ }^{2} \mathbf{F}$ \\
\hline \multirow{14}{*}{$\begin{array}{l}\text { Granite } \\
\text { Mountain } \\
\text { Porphyry- } \\
\text { Continued }\end{array}$} & GM6G & 3CLA & ND & $.09 \pm .03$ \\
\hline & & 4CLA & ND & $.16 \pm .03$ \\
\hline & 2GM6G & 4CL & ND & $.06 \pm .04$ \\
\hline & & 6CL & ND & $.07 \pm .06$ \\
\hline & & 6CLA & ND & $.10 \pm .06$ \\
\hline & 2GM4V & 1CL & ND & $.16 \pm .03$ \\
\hline & . & 1CLA & ND & $.19 \pm .04$ \\
\hline & & 3CL & ND & $.23 \pm .04$ \\
\hline & 2GM2A & 3CL & ND & $.18 \pm .09$ \\
\hline & & 4CL & ND & $.16 \pm .05$ \\
\hline & & 5CL & ND & $.16 \pm .11$ \\
\hline & 2GM1A & $2 \mathrm{CL}$ & $.03 \pm .009$ & $.23 \pm .08$ \\
\hline & & 2CLA & $.03 \pm .013$ & $.27 \pm \ldots .13$ \\
\hline & & 2CLB & $.03 \pm .008$ & $.26 \pm .13$ \\
\hline $\begin{array}{l}\text { Mineralized } \\
\text { diabase. }\end{array}$ & P70-22 & $1 \mathrm{CL}$ & $.05 \pm .016$ & $.27 \pm .13$ \\
\hline
\end{tabular}

TABLE 8.- $\mathrm{Cl}$ and $\mathrm{F}$ contents in minerals formed from biotite, plagioclase, pyroxene, and chlorite in Laramide intrusive rocks near the Ray porphyry copper deposit, Arizona

\begin{tabular}{|c|c|c|c|c|}
\hline \multirow{2}{*}{$\begin{array}{l}\text { Rock } \\
\text { type }\end{array}$} & \multirow{2}{*}{$\begin{array}{c}\text { Probe } \\
\text { sample }\end{array}$} & \multirow{2}{*}{$\begin{array}{c}\text { Grain } \\
\text { No. }\end{array}$} & \multicolumn{2}{|c|}{ Contents $^{1}$ (weight percent) } \\
\hline & & & ${ }^{2} \mathrm{Cl}$ & ${ }^{2} \mathbf{F}$ \\
\hline \multicolumn{5}{|c|}{ Epidote after biotite } \\
\hline $\begin{array}{c}\text { Tortilla } \\
\text { Quartz } \\
\text { Diorite. }\end{array}$ & $217-1$ & 6SE & ND & ND \\
\hline Rattler & $260-113 D$ & 2SE & ND & $0.11 \pm 0.05$ \\
\hline Grano- & & 5SE & ND & $.07 \pm .02$ \\
\hline diorite. & $261-25$ & 1SE & ND & $.09 \pm .08$ \\
\hline & 246-11G & 2SE & ND & $.05 \pm .02$ \\
\hline Granite & RB5 & 4SE & ND & $.06 \pm .01$ \\
\hline $\begin{array}{l}\text { Mountain } \\
\text { Porphyry. }\end{array}$ & 2GM6G & 1SE & ND & $.04 \pm .03$ \\
\hline \multicolumn{5}{|c|}{ Sphene after biotite } \\
\hline $\begin{array}{c}\text { Tortilla } \\
\text { Quartz } \\
\text { Diorite. }\end{array}$ & $217-1$ & 3SS & ND & $0.51 \pm 0.05$ \\
\hline Rattler & $246-99 B$ & 1SS & ND & $1.4 \pm .2$ \\
\hline Grano- & $261-25$ & 1SS & ND & $.18 \pm .01$ \\
\hline \multirow[t]{7}{*}{ diorite. } & 246-11G & 2SS & ND & $2.2 \pm .1$ \\
\hline & & 3SS & ND & $1.3 \pm .2$ \\
\hline & & $6 S S$ & ND & $1.0 \pm .03$ \\
\hline & 246-11A & $4 S S$ & ND & $1.1 \pm .1$ \\
\hline & $\mathrm{T} 16-630$ & $1 \mathrm{SS}$ & ND & $.74 \pm .15$ \\
\hline & & $8 \mathrm{SS}$ & ND & $1.2 \pm .07$ \\
\hline & & 10SS & ND & $.66 \pm .05$ \\
\hline \multirow{9}{*}{$\begin{array}{l}\text { Granite } \\
\text { Mountain } \\
\text { Porphyry. }\end{array}$} & RB5 & 4SS & ND & $1.7 \pm .2$ \\
\hline & & 5SS & ND & $1.5 \pm .2$ \\
\hline & GM12R & $4 \mathrm{SS}$ & ND & $.20 \pm .02$ \\
\hline & & $3 S S$ & ND & $.50 \pm .03$ \\
\hline & 2GM14 & 6SSA & ND & $.66 \pm .09$ \\
\hline & & 6SSB & ND & $.49 \pm .10$ \\
\hline & GM6G & $2 \mathrm{D}$ & $0.09 \pm 0.02$ & $2.5 \pm .3$ \\
\hline & 2GM6G & 6SSA & ND & $.44 \pm .04$ \\
\hline & & 6SSB & ND & $.65 \pm .03$ \\
\hline
\end{tabular}


TABLE 8.- $\mathrm{Cl}$ and $F$ contents in minerals formed from biotite, plagioclase, pyroxene, and chlorite in Lanide intrusive rocks near the Ray porphyry copper deposit, ArizonaContinued

\begin{tabular}{|c|c|c|c|c|}
\hline \multirow{2}{*}{$\begin{array}{c}\text { Rock } \\
\text { type }\end{array}$} & \multirow{2}{*}{$\begin{array}{c}\text { Probe } \\
\text { sample }\end{array}$} & \multirow{2}{*}{$\underset{\text { No. }}{\text { Grain }}$} & \multicolumn{2}{|c|}{ Contents ${ }^{1}$ (weight percent) } \\
\hline & & & ${ }^{2} \mathrm{Cl}$ & $2 \mathbf{F}$ \\
\hline \multicolumn{5}{|c|}{ Phengite and clay analyses } \\
\hline $\begin{array}{c}\text { Tortilla } \\
\text { Quartz } \\
\text { Diorite. }\end{array}$ & $217-1$ & $\mathbf{M S P}^{3}$ & $0.03 \pm 0.03$ & ND \\
\hline Granite & 2GM14 & $4 \mathrm{SPA}^{\mathrm{s}}$ & ND & ND \\
\hline Mountain & GM12R & $4 \mathrm{SPA}^{3}$ & ND & $0.04 \pm 0.0$ \\
\hline Porphyry & GM2A & $4 \mathrm{P}^{*}$ & ND & $.55 \pm .02$ \\
\hline & & $5 P^{4}$ & ND & $.45 \pm .08$ \\
\hline \multicolumn{5}{|c|}{ Hydrogarnet(?) after biotite } \\
\hline Tortilla & $217-28$ & $4 M$ & ND & $0.69 \pm 0.10$ \\
\hline $\begin{array}{l}\text { Quartz } \\
\text { Diorite. }\end{array}$ & & & & \\
\hline Rattler & $260-113 D$ & $\mathbf{3 M}$ & ND & $1.8 \pm .1$ \\
\hline Grano- & $\mathrm{T} 16-630$ & $5 \mathbf{M}$ & ND & $1.4 \pm .1$ \\
\hline diorite. & & $\mathbf{9 M}$ & ND & $1.6 \pm .1$ \\
\hline
\end{tabular}

\begin{tabular}{lllll}
\hline \multicolumn{4}{c}{ Fibrous amphibole analysis } \\
\hline $\begin{array}{l}\text { Tortilla } \\
\text { Quartz } \\
\text { Diorite. }\end{array}$ & $217-1$ & MFHB $^{s}$ & $0.02 \pm 0.008$ & $0.11 \pm 0.03$ \\
\hline
\end{tabular}

1 Precision calculated from standard counting error from the mean of 5 to 10 data points within a $10 \times 10 \mu \mathrm{m}$ area.

Microprobe analysis. ND, not detected at 0.02 wt percent $\mathrm{Cl}, 0.04$ wt percent F.

Alteration product of plagioclase.

Alteration product of chlorite
Reaction rim on pyroxene.

TABLE 9.-Cl and $\mathrm{F}$ contents in igneous and alteration minerals from Precambrian intrusive rocks near the Ray porphyry copper deposit, Arizona

\begin{tabular}{cllcc}
\hline $\begin{array}{c}\text { Rock type } \\
\text { (Sample No.) }\end{array}$ & Mineral & Grain & \multicolumn{2}{c}{ Contents ${ }^{2}$ (weight percent) } \\
\cline { 4 - 5 } Nuin & Biotite & 2BI & $0.13 \pm 0.01$ & $1.7 \pm 0.07$ \\
Granite & & 3BI & $.12 \pm .01$ & $1.7 \pm .09$ \\
(PCR). & & 3B12 & $.11 \pm .004$ & $1.7 \pm .04$ \\
& & M1BI & $.10 \pm .01$ & $1.8 \pm .15$ \\
& Chlorite & 2CL & ND & $0.44 \pm .01$ \\
& & 3CL & ND & $.43 \pm .03$ \\
& & 4CL & ND & $.37 \pm .04$ \\
& Apatite & 3A & $.11 \pm .02$ & $3.3 \pm .14$ \\
& & 3A2 & $.11 \pm .01$ & $3.3 \pm .09$ \\
Diabase & Biotite & MBI & $.24 \pm .04$ & \\
(DBA-32). & Apatite & $\mathbf{7 A}$ & $.83 \pm .06$ & $2.1 \pm .28$ \\
\hline
\end{tabular}

1 Precision calculated from standard counting error from the mean of 5 to 8 data points in a $10 \times 10 \mu \mathrm{m}$ area.

${ }^{2}$ Microprobe analysis. ND, not detected at 0.02 wt percent $\mathrm{Cl}, 0.04$ wt percent $F$.

fine to resolve, and also one grain of fibrous amphibole formed from pyroxene are included in table 8 . $\mathrm{Cl} \mathrm{oc-}$ curs near or below detection level in the clay, phengites, and amphibole; only the intensely altered area in the plagioclase, the phengite derived from chlorite, and the amphibole contain detectable amounts of $\mathrm{F}$.

\section{Intrasample variations and zoning}

The igneous minerals in the Laramide rocks studied have not been homogenized with respect to the halogens (or other constituents; author, unpub. data) by exchange with magma, magmatic fluid, or postmagmatic fluid. Measurably different abundances of one or both halogens occur between like-mineral grains in the same sample (40 percent of the samples for apatite, 25 percent for biotite, and 35 percent for hornblende) and zoning of major and (or) minor elements is found in apatite, biotite, and hornblende as well as in plagioclase. Analytically distinguishable zoning of $\mathrm{Cl}$ or $\mathrm{F}$, or both, occurred in 11 of 34 apatite grains and in 9 of 16 hornblende grains studied for zoning, whereas zoning of the halogens in biotite was seldom detected (compare grain numbers ending in $\mathrm{C}$, centers, and $\mathrm{E}$, edges; table 4). Neither the zoning or abundance of $\mathrm{Cl}$ or $\mathrm{F}$ in the igneous minerals seems related to the amount of plagioclase or mafic minerals altered in a sample (table 1), proximity of altered grains to the one analyzed, or the potential susceptibility of a grain to exchange by virtue of its size or inclusion in other minerals. (See mineral occurrence data in table 3 , and in footnotes of tables 4 and 6.) However, although the minerals have not been homogenized with respect to the halogens, there are no firm trends in the variations (figs. 6 and 7). This suggests that if the observed abundances and variations retain an imprint of those obtained from the magma, then the conditions controlling uptake of $\mathrm{Cl}, \mathrm{F}$, and $\mathrm{H}_{2} \mathrm{O}$ by the minerals from the magma were complex. Not enough data were collected for epidote or sphene to make conclusions regarding zoning of $\mathrm{Cl}$ and $\mathrm{F}$.

\section{Intersample variations with rock chemistry, Laramide rocks}

The abundanees of $\mathrm{Cl}, \mathrm{F}$, and $\mathrm{H}_{2} \mathrm{O}+$ in the igneous minerals vary measurably between samples, and these variations appear to be related to greater or lesser degree to variations in whole-rock chemistry (as indicated by differentiation indices, D.I., of the samples). The abundance of $\mathrm{Cl}$ in apatite and biotite correlates negatively with rock D.I. (fig. 8), the abundance of $\mathrm{F}$ in apatite, biotite, sphene, and perhaps hornblende correlates positively with rock D.I. (fig. 9 ; tables 6 and 1 for sphene), and the abundance of calculated $\mathrm{H}_{2} \mathrm{O}+$ in apatite, biotite, sphene, and perhaps hornblende correlates negatively with rock D.I. (fig. 10 ; tables 6 and 1 for sphene). Correlations of the mineral contents of $\mathrm{Cl}, \mathrm{F}$, and $\mathrm{H}_{2} \mathrm{O}+$ with rock D.I. for the samples from the Rattler Granodiorite generally mirror but are not as strong as those for the entire sample suite. Table 10 

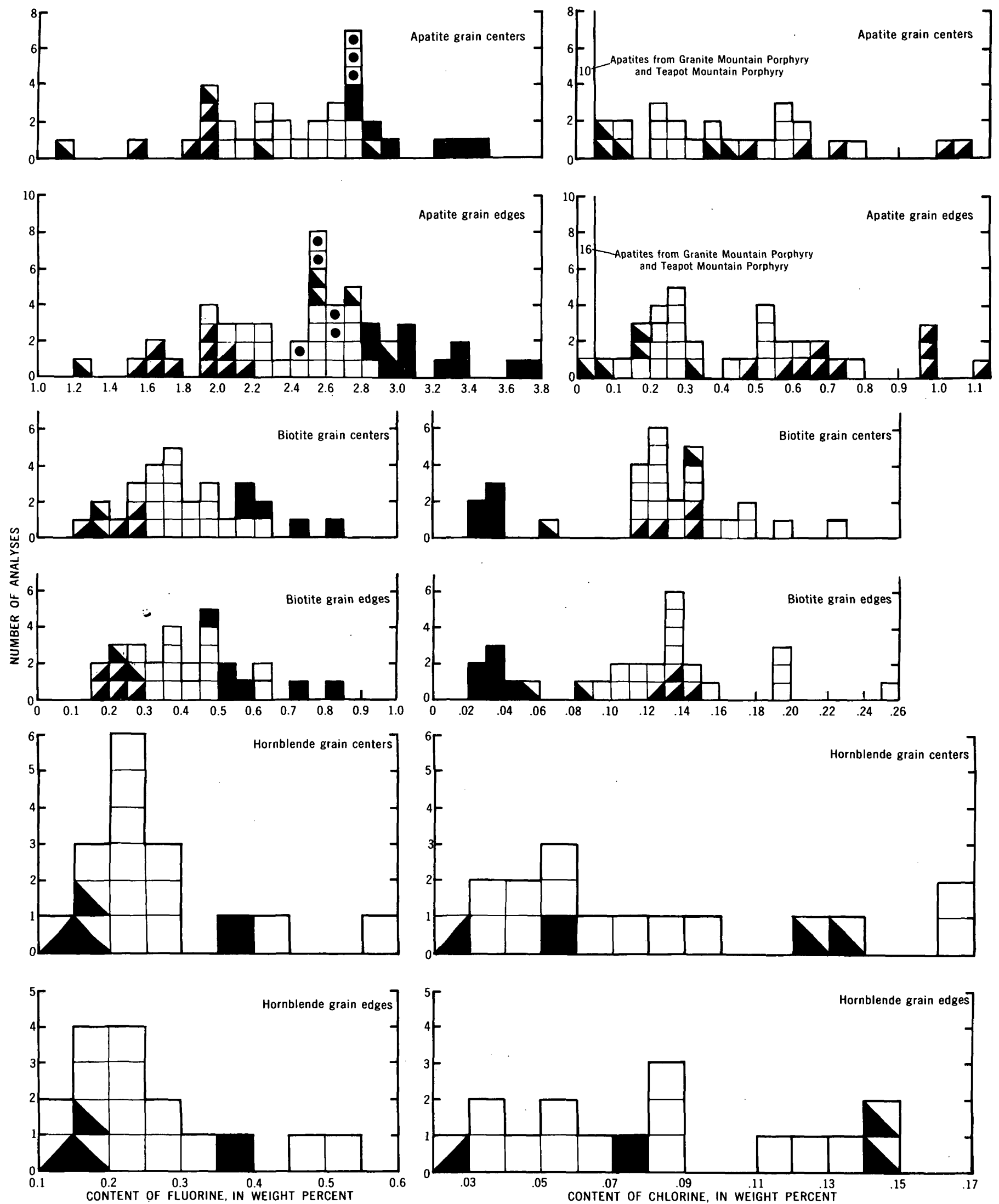

Tortilla Quartz Diorite $\square$ Rattler Granodiorite

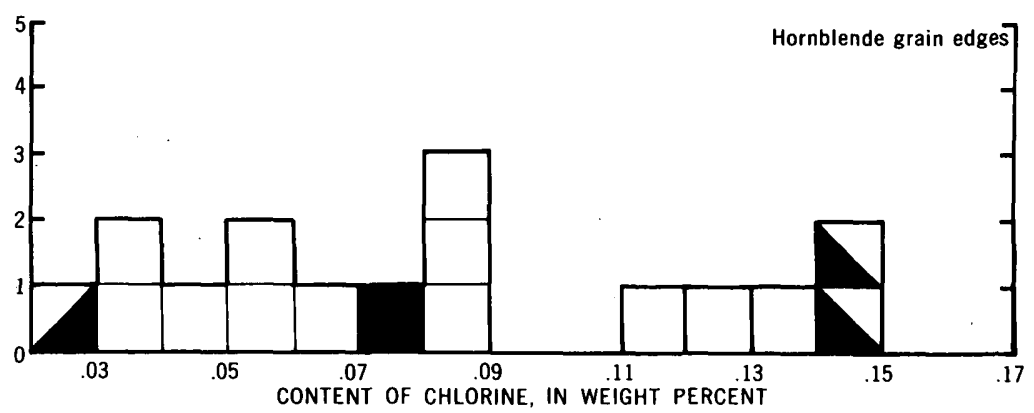

Rhyodacite dikes

Granite Mountain Porphyry

Teapot Mountain Porphyry

Figure 6.-Frequency distribution of $\mathrm{F}$ and $\mathrm{Cl}$ contents in centers and edges of apatite, biotite, and hornblende grains, Laramide rocks. 
ROW 1, TORTILLA QUARTZ DIORITE GRAINS ANALYZED
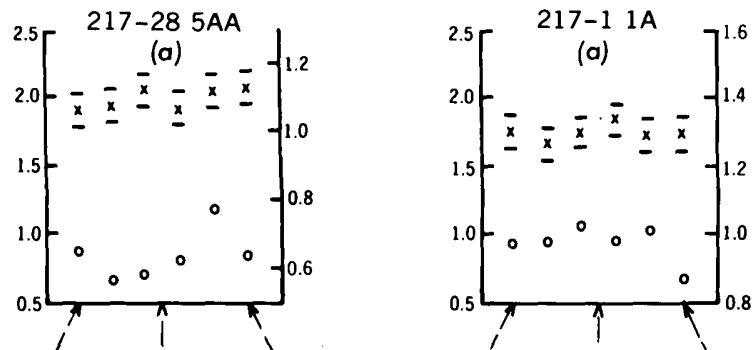

ROW 2, RATTLER GRANODIORITE GRAINS ANALYZED

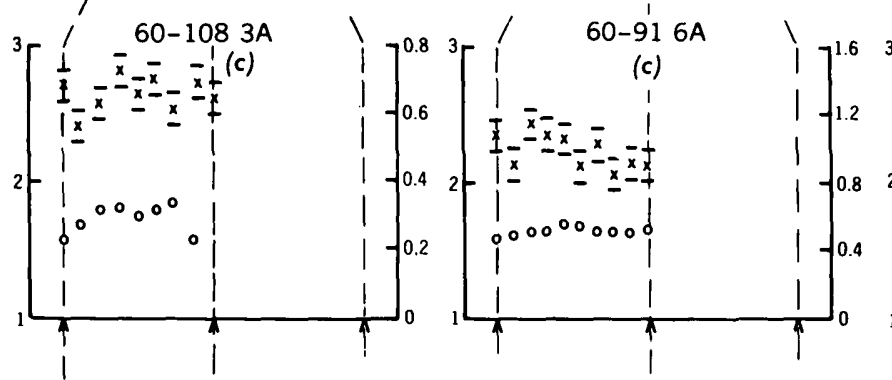

ROW 3, RATTLER GRANODIORITE GRAINS ANALYZED

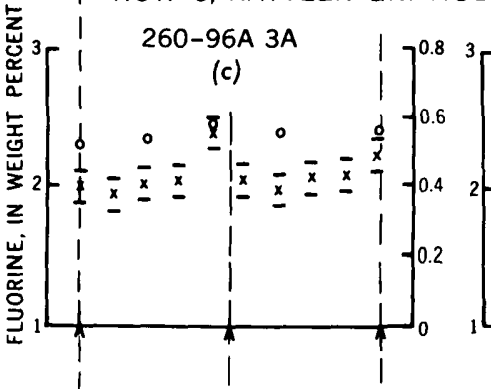

ROW 4, GRANITE MOUNTAIN PORPHYRY GRAINS ANALYZED
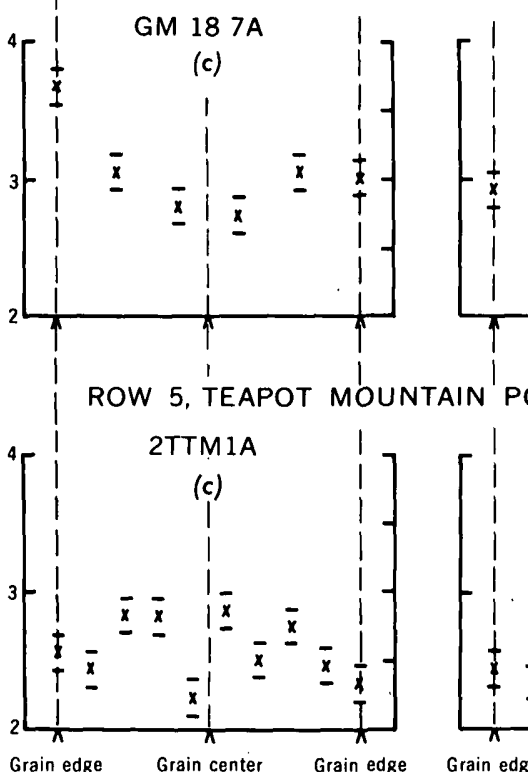

GM 188 A

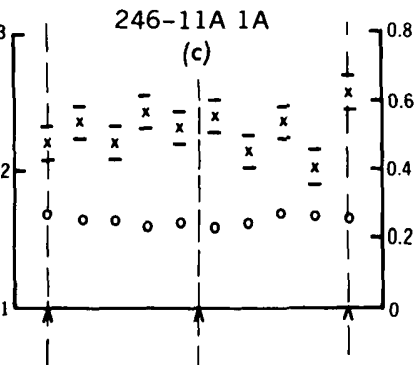

0.8
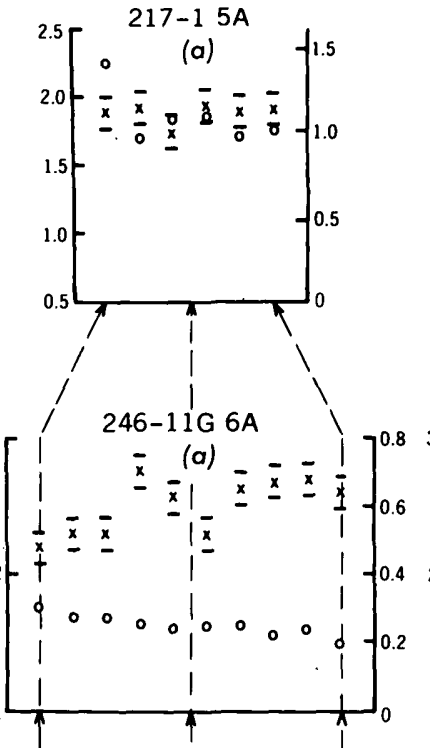

246-11A 3A 

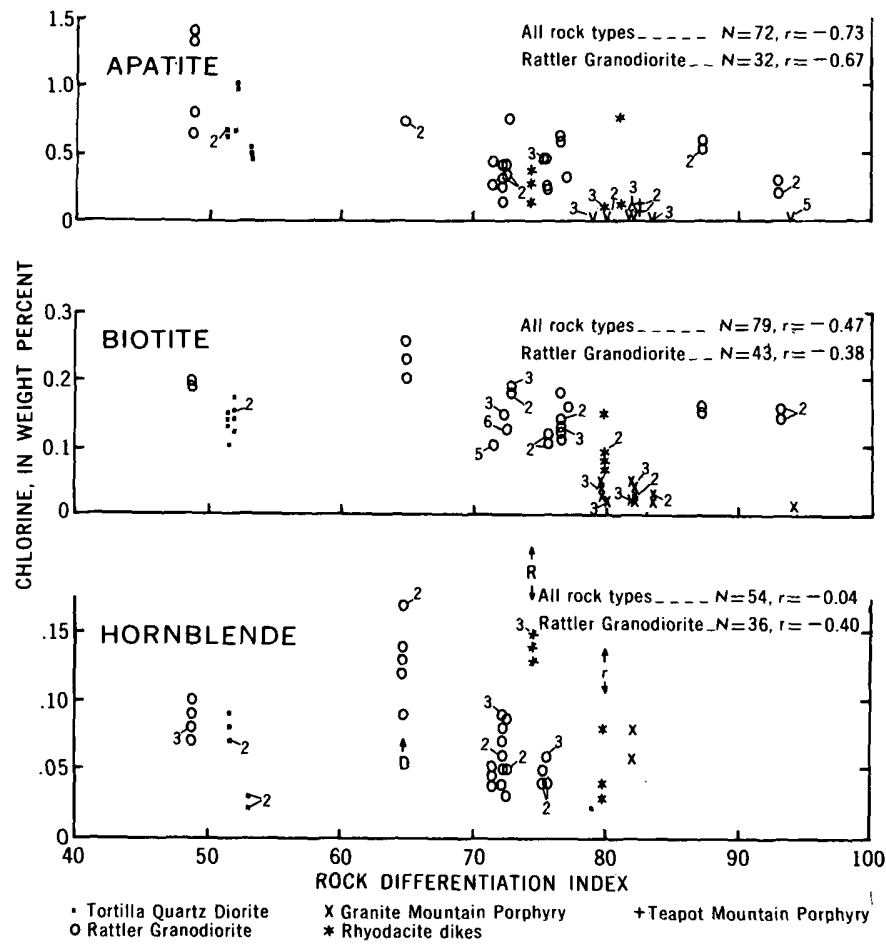

Fraure 8.-Variations of $\mathrm{Cl}$ content of mineral with rock differentiation index.
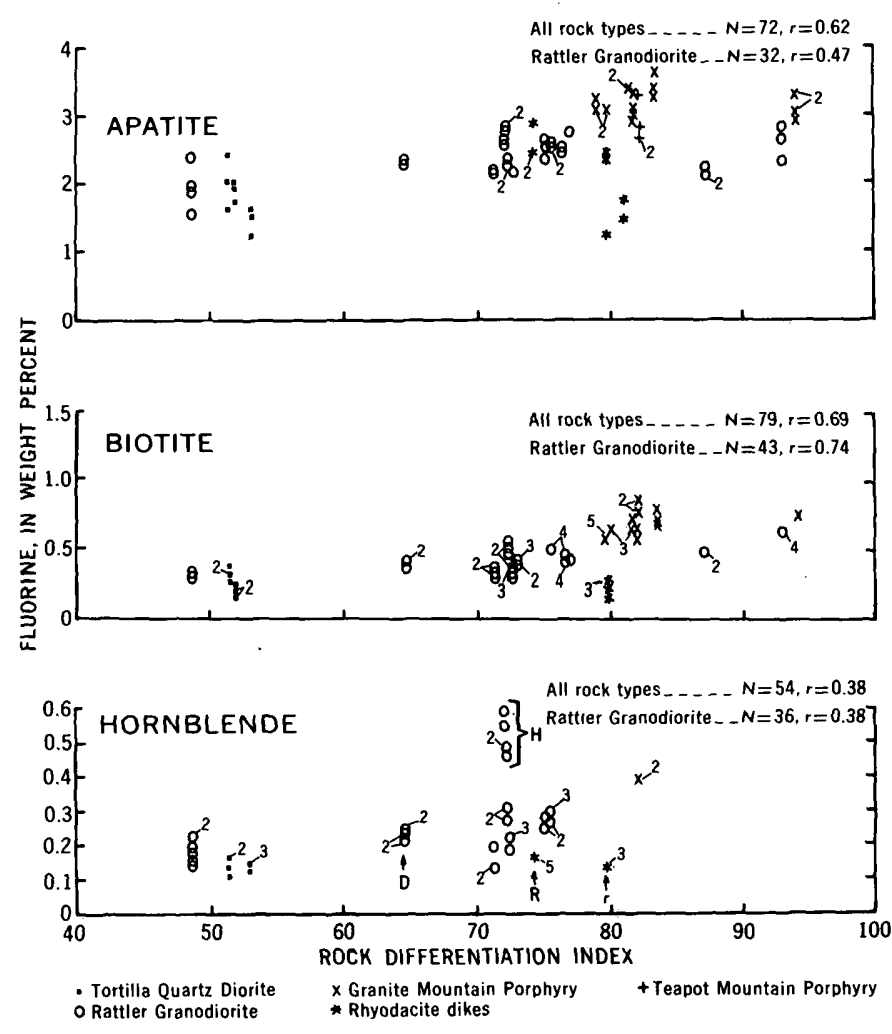

Frgure 9.-Variations of $F$ content of mineral with rock differentiation index.
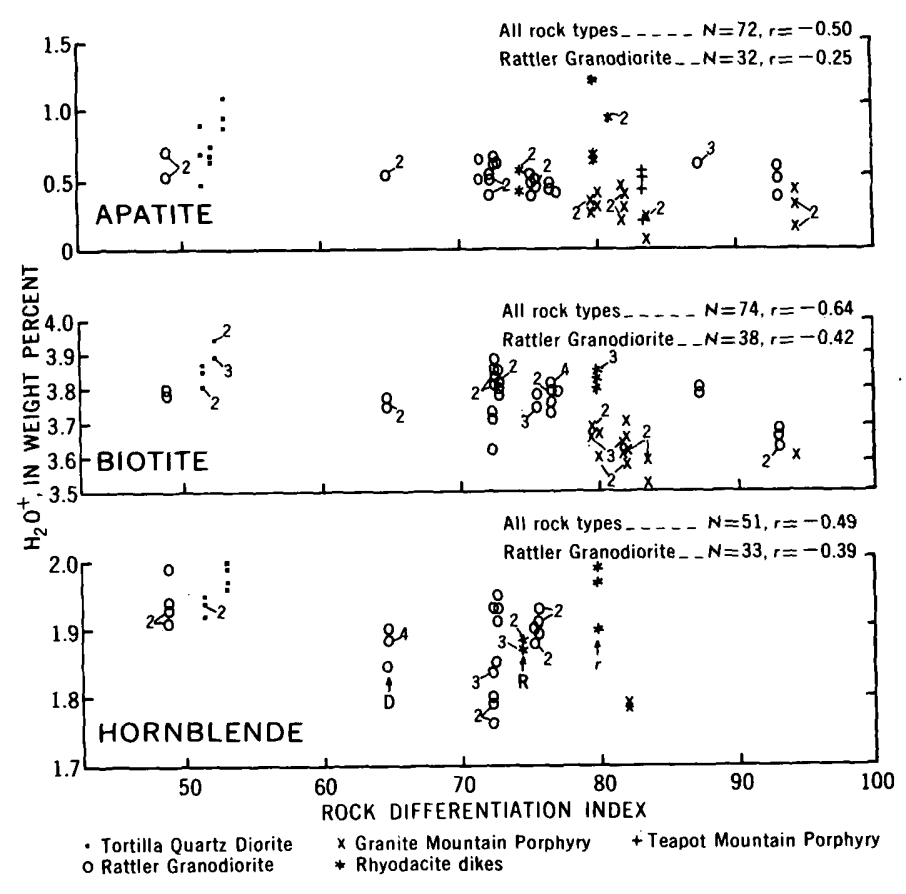

FIGURE 10.-Variations of calculated $\mathrm{H}_{2} \mathrm{O}+$ content of mineral with rock differentiation index.

ing $|0.65|$ and are thought to have geological significance. Fifty-five percent of the trends have correlation coefficients that exceed $|0.50|$, and all but one of those with coefficients less than $|0.65|$ have the same slope as the trends with high correlation coefficients.

The positive association of the abundance of $\mathrm{F}$ and a negative or lack of association of the abundance of $\mathrm{Cl}$ and $\mathrm{H}_{2} \mathrm{O}+$ in the minerals with increasing differentiation index of the host rock is not unique to the Ray igneous suite. Goldschmidt (1954) found that the F content of igneous minerals increases as the host rock becomes more felsic. The $\mathrm{Cl}$ and $\mathrm{H}_{2} \mathrm{O}+$ contents are higher and the $\mathrm{F}$ contents lower in apatites from mafic rocks than in apatite from more felsic rocks (A. Kind, cited by Correns, 1956; Taborszky, 1962). Nash (1972a, b) reported that the $\mathrm{F}$ content of apatite increased with differentiation of the Iron Hill complex and Shonkin Sag laccolith, and his data indicate that the $\mathrm{Cl}$ content of apatite either remained the same or decreased as the host rocks became more differentiated in both intrusive suites. Lee and Van Loenen (1970) found that the $\mathrm{F}$ content of biotite increases with decreasing $\mathrm{CaO}$ content of hybrid rocks of the southern Snake Range, Nev., and the data of Ivanov (1971), Dodge and Moore (1968), Dodge and others (1968, 1969), Dodge and Ross (1971) suggest the same for $F$ content of biotite from igneous rocks of central Chukatka, Russia, the Sierra Nevada batholith, and the 
TABLE 10.-Statistical data for $\mathrm{Cl}, \mathrm{F}$, and $\mathrm{H}_{8} \mathrm{O}+$ contents of minerals and rocks plotted against differentiation index

(flgures 8-12)

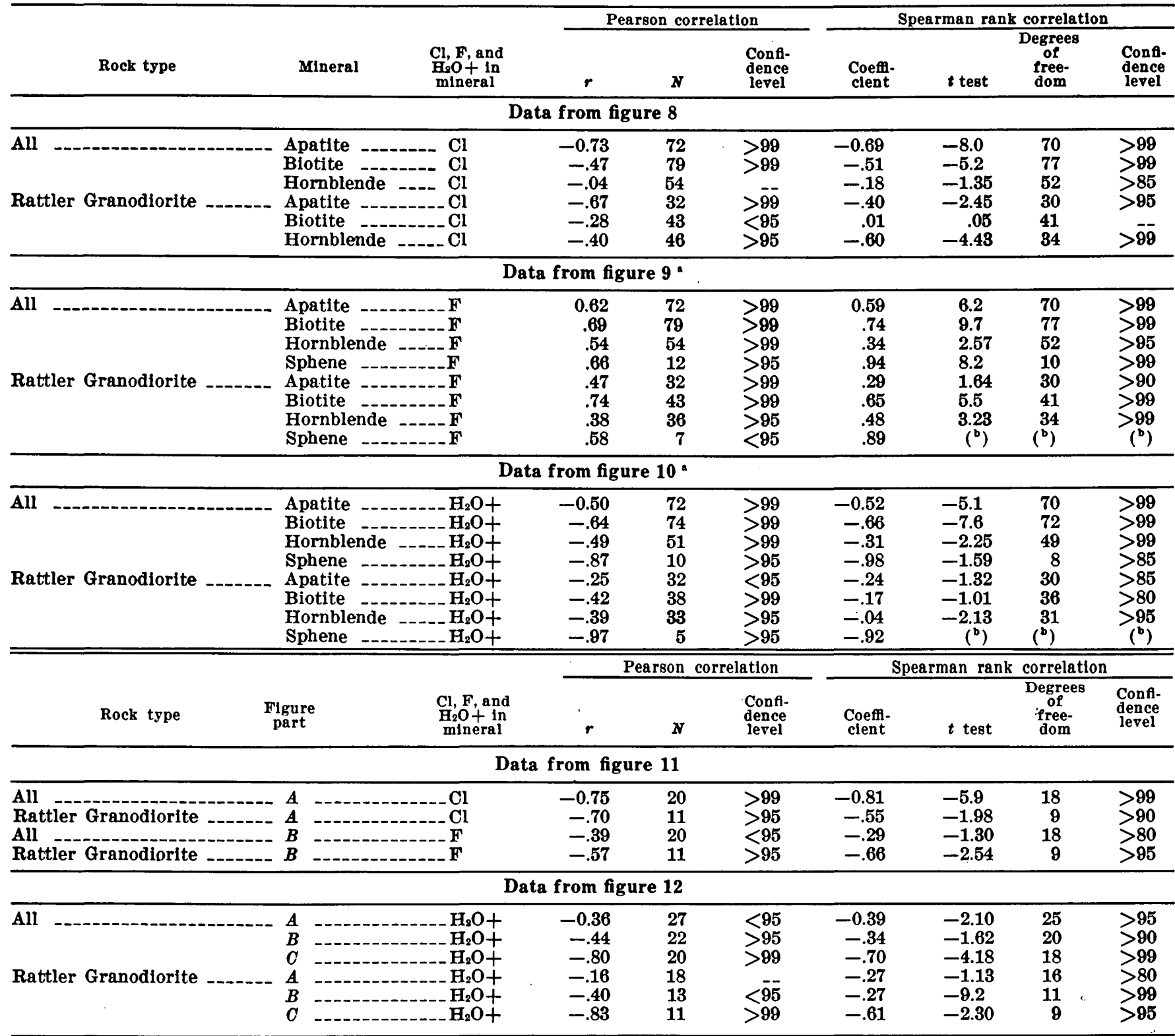

- Sphene not included in figures 9 and 10. b Small sample set.

California Transverse and Coast Ranges. In addition, the $\mathrm{Cl}$ and $\mathrm{H}_{2} \mathrm{O}+$ contents of biotite and hornblende in the Sierra Nevada batholith (data of Dodge and others, 1968, 1969), intrusive rocks of the Coast and Transverse Ranges (data of Dodge and Ross, 1971), and of Scandinavian granites (Gillberg, 1964) either correlate negatively or do not correlate with increasing host rock acidity.

Intersample variations with sample age, Laramide rocks

Minerals from the oldest Laramide stocks at Ray (Tortilla Quartz Diorite, Rattler Granodiorite) generally contain more $\mathrm{Cl}$ and $\mathrm{H}_{2} \mathrm{O}+$ and less $\mathrm{F}$ than minerals from the younger stocks (Granite Mountain Porphyry, Teapot Mountain Porphyry). This correlation between the age of a pluton and the $\mathrm{Cl}, \mathrm{F}$, and $\mathrm{H}_{2} \mathrm{O}+$ content of its minerals is expected because the contents of these components in the minerals appear related to rock chemistry and, in general, there is a negative correlation between rock differentiation index and the age of the rock type. There are five exceptions: (1) Apatite from the Teapot Mountain Porphyry contains about the same or a little more $\mathrm{Cl}$ and $\mathrm{H}_{2} \mathrm{O}+$ and perhaps less $\mathrm{F}$ than apatite in the older Granite Mountain Porphyry; (2) hornblende in sample 17-16 ( $R$ in figs. 8-10) contains more $\mathrm{Cl}$ than hornblende in 
the Tortilla Quartz Diorite which it cuts; (3) biotite in sample GM100 ( $r$ in figs. 8-10) contains less $\mathrm{F}$ and more $\mathrm{H}_{2} \mathrm{O}+$ than the older Rattler Granodiorite; (4) apatite in sample $61-2 \mathrm{~F}$ (asterisk symbols in figs. 8-10 plotted at greater than 80 differentiation index), which may be the youngest intrusive type studied, contains less $\mathrm{F}$ and more $\mathrm{Cl}$ and $\mathrm{H}_{2} \mathrm{O}+$ than apatite from the Granite Mountain Porphyry; and (5) hornblende and biotite in sample 60-113D ( $D$ in figs. 8-10), which was intruded as a late dike in the Rattler Granodiorite but prior to aplite development (Cornwall and others, 1971), contain more $\mathrm{Cl}$ than do the hornblende and biotite from the samples cut by the dike.

Four of the five exceptions involve minerals from dikes that probably were more susceptible than the stocks to gain and loss of $\mathrm{Cl}, \mathrm{F}$, and $\mathrm{H}_{2} \mathrm{O}+$ by diffusion and contamination. Moreover, for most of the exceptions, only one or two rather than all three components are present in a given mineral in amounts anomalous for the age of the sample, and in several of the exceptions, one of the other coexisting minerals does not show the anomaly.

\section{Intersample variations with rock texture and modal abundance, Laramide rocks}

Porphyritic texture is sometimes attributed to the buildup and release of volatiles from a cooling magma (pressure quenching, Jahns and Tuttle, 1963). Thus one should perhaps expect the hydrous minerals in porphyritically textured rocks to have different halogen and water contents compared to like minerals in nonporphyritic rocks. However, the halogen and water contents of the igneous minerals are not consistently related to the texture (even porphyritic texture) of the rock. (Compare rock textures in table 1 with data in tables 3-5 or figures 8-10).

Competition for the available water and halogens in the magminas also might be expected to affect the amount of water and halogens incorporated by the minerals, and this might be detected by comparing the compositions of like minerals from samples from the same rock type having like differentiation index but different modal composition. However, a consistent pattern does not emerge from such comparisons. For example, hornblende in sample 48-29 (Tortilla Quartz Diorite) contains three times less $\mathrm{Cl}$ and is three times as abundant as the hornblende in sample 17-28, but the $\mathrm{F}$ contents of the hornblende in the two samples are not appreciably different. Similarly, samples $61-25$ and $60-91$ of the Rattler Granodiorite have almost identical differentiation indices as those of samples 60-108 and 60-111 and contain half the amount of biotite (about 6 percent) as that in sample $60-111$, which contains no hornblende, and half the amount of hornblende (about 4 percent) as that of sample $60-108$, which contains no biotite. Thus because there are about two times fewer sites for halogens in sample $60-108$, one would expect to find more halogens in hornblende of sample $60-108$ than in hornblende of samples $61-25$ and $60-91$; hornblende of sample 60-108 contains comparably more $\mathrm{F}$ but not more Cl. Likewise one would perhaps expect a little less of the halogens in the biotite of sample 60111 compared to that in biotite of samples $61-25$ and 60-91. However, biotite in sample 60-111 contains a little more $\mathrm{Cl}$, and about the same amount of $\mathrm{F}$ as biotite in samples $61-25$ and $60-91$.

\section{$\mathrm{Cl}, \mathrm{F}$, and $\mathrm{H}_{2} \mathrm{O}$ variations with changes in mineral chemistry}

The uptake of the halogens and water by the hydrous minerals may be affected by the substitution of other elements in the minerals. This possibility, although considered secondary compared to the variations linked to changes in magma chemistry and age (figs. 8-10), was investigated by comparing variations of halogen abundances with variations in the abundances of other elements in (1) individual grains (zoning) and in (2) all like-mineral grains from the same stock or rock type and from all rock types. For the first comparison, the number and type of correlation (positive. negative, or none) were tabulated for all grains that were studied for zoning in each rock type. No trends emerged from these data for apatite, biotite, and hornblende (summarized in table 11). The data for sphene and epidote were not sufficient for this type of comparison. For the second comparison, correlation matrices were constructed to check for coupled substitution between $\mathrm{Cl}$ and $\mathrm{F}$ and other elements in the minerals. In these data, trends did emerge for certain elements in apatite, biotite, and hornblende (tables 12-14). However, the correlations do not determine whether $\mathrm{Cl}, \mathrm{F}$, and $\mathrm{H}_{2} \mathrm{O}+$ vary in abundance in response to substitution of the other elements in the minerals (with the possible exception of $\mathrm{Cl}$ with $\mathrm{Mg}$ and $\mathrm{Fe}$ in hornblende) or whether the abundance of the halogens and water as well as the other elements in the minerals all changed in response to changes in the magma(s). For example, the $\mathrm{MgO}$ content of biotite correlates positively with the $\mathrm{Cl}$ content of biotite, but because $\mathrm{Cl}$ and $\mathrm{MgO}$ of biotite both vary negatively in abundance with the differentiation index of the samples, it is unclear whether $\mathrm{Cl}$ varies in abundance mainly because of coupled substitution with $\mathrm{Mg}$ or mainly because of changes in the magma. In view of the zoning studies and the similar correlations between $\mathrm{Cl}$ abundance in other minerals and rock chemistry, the changes 
in magma are considered most likely. The same is probable for the other correlations between the abundance of an element in biotite, apatite, or hornblende and the abundance of $\mathrm{Cl}, \mathrm{F}$, or $\mathrm{H}_{2} \mathrm{O}+$ in the mineral because they either are not consistent from rock type to rock type, are not significant, or are matched by appropriate negative or positive correlations with rock differentiation index.

TABLE 11.-Comparative zoning of halogens and oxides in apatite, biotite, and hornblende

[Data are number of correlations tabulated for all grains studied]

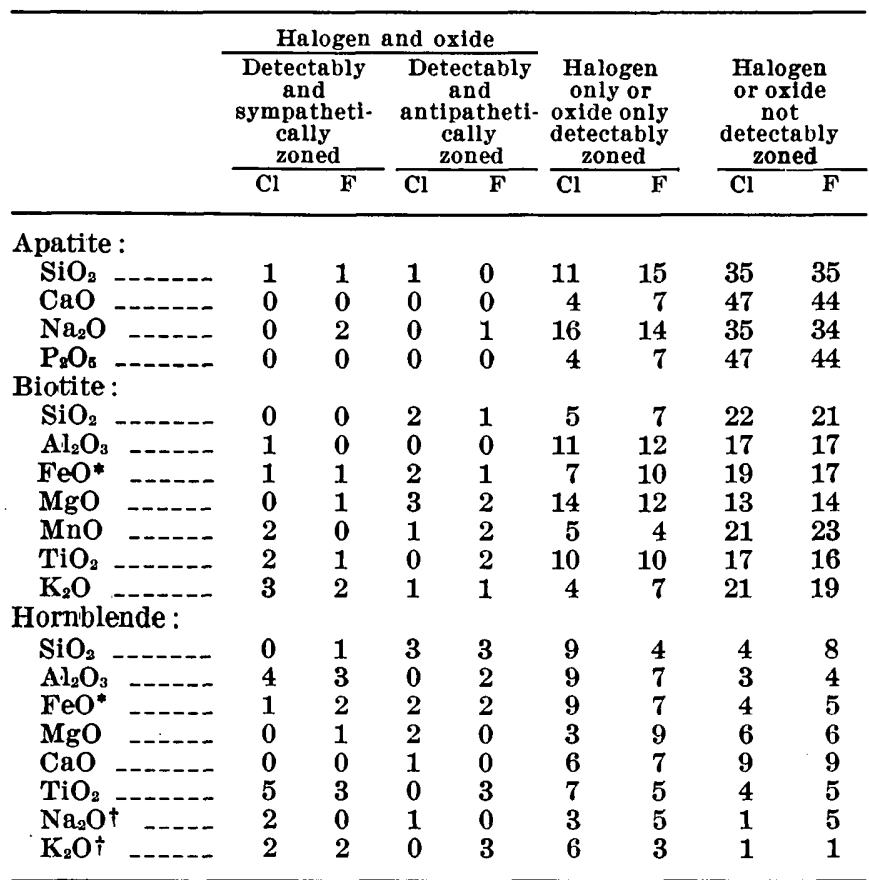

* All Fe calculated as FeO

$\dagger$ Fewer correlations for $\mathrm{Na}_{2} \mathrm{O}$ and $\mathrm{K}_{2} \mathrm{O}$.

TABLE 12.-Partial correlation matrices of apatite chemistry and rock differentiation index

[Italic figures represent correlation at less than 95-percent confidence level. $N$, number of observations in a population ]

\begin{tabular}{|c|c|c|c|c|c|}
\hline & $\mathrm{SiO}_{2}$ & $\mathrm{CaO}$ & $\mathrm{Na} \mathrm{O}_{3}$ & $\mathrm{P}_{2} \mathrm{O}_{5}$ & D.I. \\
\hline \multicolumn{6}{|c|}{ Tortilla Quartz Diorite $(N, 9)$} \\
\hline $\begin{array}{c}\mathrm{Cl}- \\
\mathrm{F} \\
\mathrm{D} \\
\mathrm{D} . \mathrm{I} .\end{array}$ & $\begin{array}{r}0.38 \\
.21 \\
-.13 \\
\end{array}$ & $\begin{array}{r}0.29 \\
.32 \\
.44 \\
\end{array}$ & $\begin{array}{r}0.28 \\
.15 \\
.97 \\
\end{array}$ & $\begin{array}{r}0.22 \\
.13 \\
.72 \\
\end{array}$ & $\begin{array}{r}0.33 \\
.26 \\
1.00 \\
\end{array}$ \\
\hline \multicolumn{6}{|c|}{ Rattler Granodiorite $(N, 30)$} \\
\hline $\begin{array}{c}\text { Cl } \\
\text { F } \\
\text { D.I. }\end{array}$ & $\begin{array}{r}-0.09 \\
.09 \\
.25 \\
\end{array}$ & $\begin{array}{r}-0.37 \\
.16 \\
.06 \\
\end{array}$ & $\begin{array}{r}-0.08 \\
.00 \\
.52 \\
\end{array}$ & $\begin{array}{r}0.37 \\
.31 \\
-.59 \\
\end{array}$ & $\begin{array}{r}-0.67 \\
.47 \\
1.00 \\
\end{array}$ \\
\hline \multicolumn{6}{|c|}{ Granite Mountain Porphyry $(N, 17)$} \\
\hline $\begin{array}{l}\text { Cl } \\
\text { F }-. . . \\
\text { D.I. }\end{array}$ & $\begin{array}{r}-0.12 \\
.03 \\
.26 \\
\end{array}$ & $\begin{array}{r}-0.20 \\
.50 \\
-.01\end{array}$ & $\begin{array}{r}0.01 \\
-.03 \\
.36\end{array}$ & $\begin{array}{l}-0.35 \\
-.24 \\
-.34\end{array}$ & $\begin{array}{r}0.29 \\
.04 \\
1.00\end{array}$ \\
\hline \multicolumn{6}{|c|}{ All rock types $(N, 70)$} \\
\hline 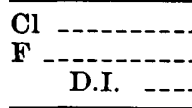 & $\begin{array}{r}0.08 \\
-.09 \\
.09\end{array}$ & $\begin{array}{r}-0.12 \\
-.12 \\
-.13\end{array}$ & $\begin{array}{r}0.12 \\
-.06 \\
.29\end{array}$ & $\begin{array}{r}0.20 \\
-.20 \\
-.10\end{array}$ & $\begin{array}{r}-0.73 \\
.62 \\
1.00\end{array}$ \\
\hline
\end{tabular}

TABLE 13.-Partial correlation matrices of biotite chemistry and rock differentiation index

[Italic figures represent correlation at less than 95-percent confldence level, $N$, number of observations in a population.

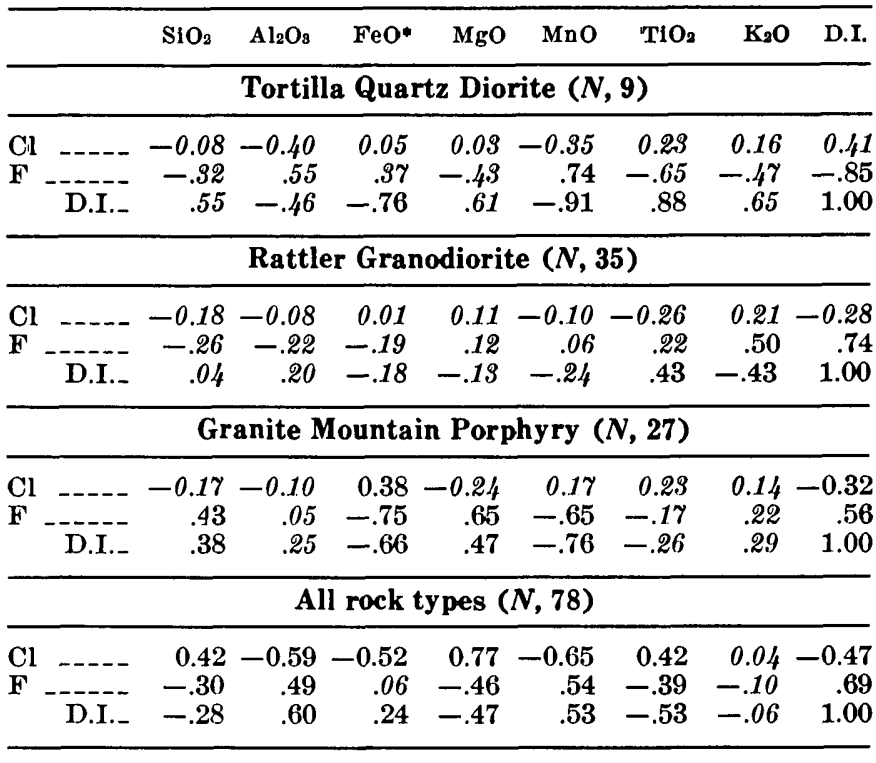

* All Fe calculated as FeO.

TABLE 14.-Partial correlation matrices of hornblende chemistry and rock differentiation index

[Italic figures represent correlation at less than 95-percent confldence level. $N$, number of observations in a population ]

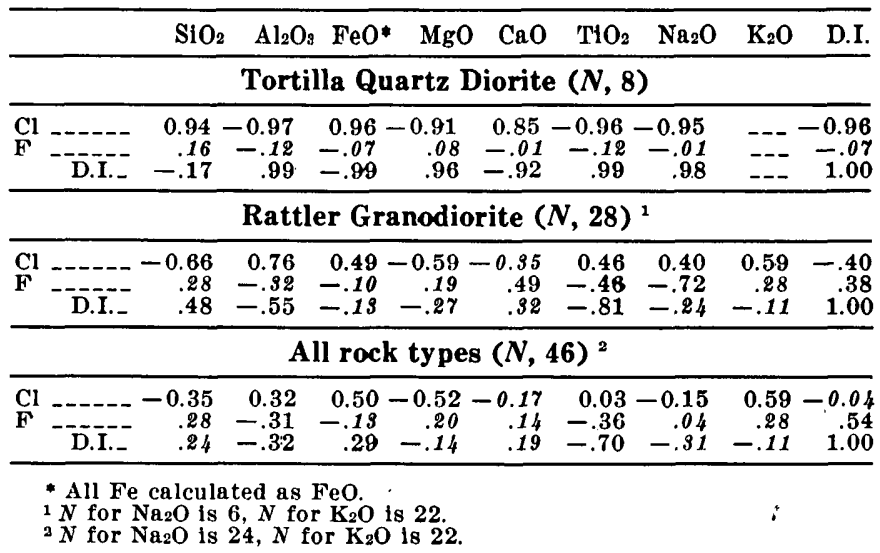

\section{$\mathrm{Cl}, \mathrm{F}$, and $\mathrm{H}_{2} \mathrm{O}+$ contents of the rocks}

The amounts of $\mathrm{Cl}$ and $\mathrm{H}_{2} \mathrm{O}+$ (figs. $11 \mathrm{~A}, 12 C$ ) contributed to the rocks by the hydrous igneous minerals decrease with decreasing age and increasing differentiation index of the rock, whereas the amount of $F$ contributed decreases only in the aplitic differentiates of the stocks (fig. 12B; table 10). These figures were constructed using the mineral analyses, measured rock specific gravities, assumed mineral specific gravities, and modal abundances of the minerals (including their pseudomorphic alteration products) and ignoring the secondary hydrous phases formed in the anhydrous silicates. The trends therefore do not necessarily reflect the actual amount of original $\mathrm{Cl}, \mathrm{F}$, or $\mathrm{H}_{2} \mathrm{O}+$ in 


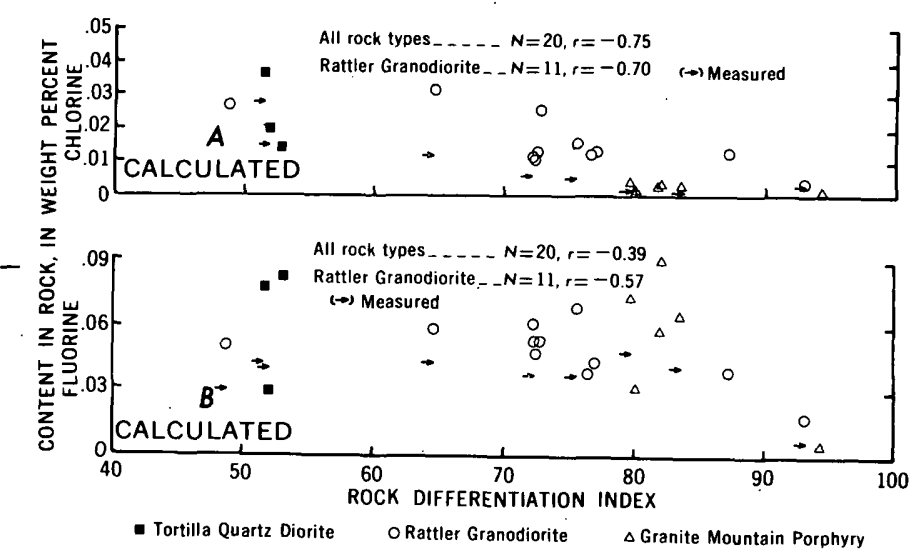

Frgure 11.-Variation of $\mathrm{Cl}$ and $\mathrm{F}$ contents of rock samples with differentiation index. Symbols represent calculated values; arrows represent measured amount in water-leached rock powders.
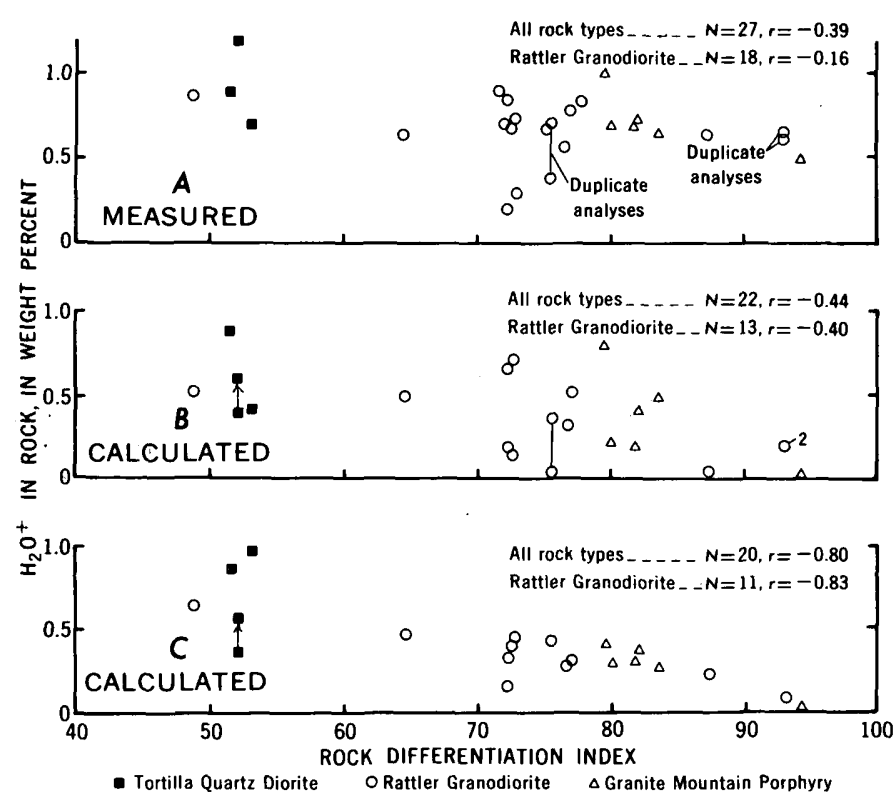

Figure 12.-Variation of $\mathrm{H}_{2} \mathrm{O}+$ contents of rock sample with rock differentiation index. $A$, Measured. $B$, Corrects $A$ by removing effects of alteration products. $C$, Calculated from rock and mineral densities, mineral analyses, and modal abundance of originally unaltered igneous minerals.

the magmas because of the possibilities (1) that some of the alteration products of the igneous minerals are deuteric and thus drew halogens and water from the melt or (2) that halogens or water were either gained by or lost from the magma or rock, although for $\mathrm{F}$ experimental work suggests that little $\mathrm{F}$ would leave the magmas via an aqueous phase (Burnham, 1967).

Also plotted, as horizontal arrows, in figures $11 A$ and $11 B$ (data in table 15 ) are whole-rock analyses of $\mathrm{Cl}$ and $\mathrm{F}$ in finely ground, water-leached splits (to remove salts deposited from ground water) of a few
TABLE 15.- $\mathrm{Cl}$ and $\mathrm{F}$ contents of some Laramide igneous rocks near Ray porphyry copper deposit

\begin{tabular}{|c|c|c|c|c|c|c|c|}
\hline \multirow{3}{*}{ Rock type } & \multirow{3}{*}{$\begin{array}{c}\text { Sample } \\
\text { No. }\end{array}$} & \multicolumn{6}{|c|}{ Contents (weight percent) } \\
\hline & & \multicolumn{3}{|c|}{$\mathbf{C l}$} & \multicolumn{3}{|c|}{ F } \\
\hline & & (a) & (b) & (c) & (a) & (b) & (c) \\
\hline \multirow{3}{*}{$\begin{array}{l}\text { Tortilla } \\
\text { Quartz } \\
\text { Diorite. } \\
\text { Rattler } \\
\text { Grandiorite. }\end{array}$} & $\begin{array}{l}17-28 \\
17-1\end{array}$ & $\begin{array}{r}0.058 \\
.048\end{array}$ & $\begin{array}{r}0.028 \\
.015\end{array}$ & $\begin{array}{r}0.037 \\
.020\end{array}$ & $\begin{array}{r}0.039 \\
.037\end{array}$ & $\begin{array}{r}0.042 \\
.040\end{array}$ & $\begin{array}{r}0.077 \\
.028\end{array}$ \\
\hline & 46-99B & $0 . \overline{0} \overline{5}$ & 0.015 & $\begin{array}{r}0.027 \\
.035\end{array}$ & $\begin{array}{r}0,026 \\
.039\end{array}$ & $\begin{array}{r}0.030 \\
.042\end{array}$ & $\begin{array}{r}0.050 \\
.060\end{array}$ \\
\hline & $\begin{array}{l}T 16-630 \\
61-25 \\
46-11 G \\
46-11 A\end{array}$ & $\begin{array}{l}.023 \\
.036 \\
.019 \\
050\end{array}$ & $\begin{array}{l}.012 \\
.006 \\
.005 \\
.003\end{array}$ & $\begin{array}{l}.0 \overline{13} \\
.016 \\
.004\end{array}$ & $\begin{array}{l}.049 \\
.037 \\
.032 \\
.006\end{array}$ & $\begin{array}{l}.052 \\
.036 \\
.036 \\
.007\end{array}$ & $\begin{array}{l}.064 \\
.068 \\
.018\end{array}$ \\
\hline Granite & RB5 & 0.033 & $<0.001$ & 0.004 & 0.049 & 0.052 & 0.070 \\
\hline $\begin{array}{l}\text { Mountain } \\
\text { Porphyry. }\end{array}$ & & .14 & $<.001$ & & .039 & .040 & .066 \\
\hline
\end{tabular}

a Chemical analysis by R. Moore and J. Budinsky.

b Whole-rock split ground to -325 mesh, leached with distilled water, dried at $90^{\circ} \mathrm{C}$, and reanalyzed. A slight increase in the amount of $F$ may reflect contamination by laboratory dust not completely compensated by blanks run simultaneously. Analysts, $R$. Moore and $J$. Budinsky.

c Amount of $\mathrm{Cl}$ and $\mathrm{F}$ in the rock contributed by original igneous minerals (calculated using modal data and electron-microprobe mineral analyses).

selected samples. These measured values confirm the trends (or lack of them) in figure 11 determined by calculation. However, the measured values are less than the calculated values for the halogen contents of the rock (except for $F$ of sample 17-1, table 15). This discrepancy is expected for $\mathrm{Cl}$ because the $\mathrm{OH}$-bearing alteration minerals of biotite contain less $\mathrm{Cl}$ than the biotite (fig. 13), and the loss of $\mathrm{Cl}$ cannot be wholly compensated by the $\mathrm{Cl}$ that might occur in alteration products of the feldspars (table 8 ). On the other hand, because the $\mathrm{F}$ content of some of the biotite alteration products is. considerably greater than the host biotite (fig. 13), the higher values of $\mathrm{F}^{\mathrm{c}}$ versus $\mathrm{F}^{\mathrm{b}}$ (see footnote explanations in table 15) were not expected. It is not known if the higher values $\left(\mathrm{F}^{\mathrm{c}}\right.$ in table 15) are
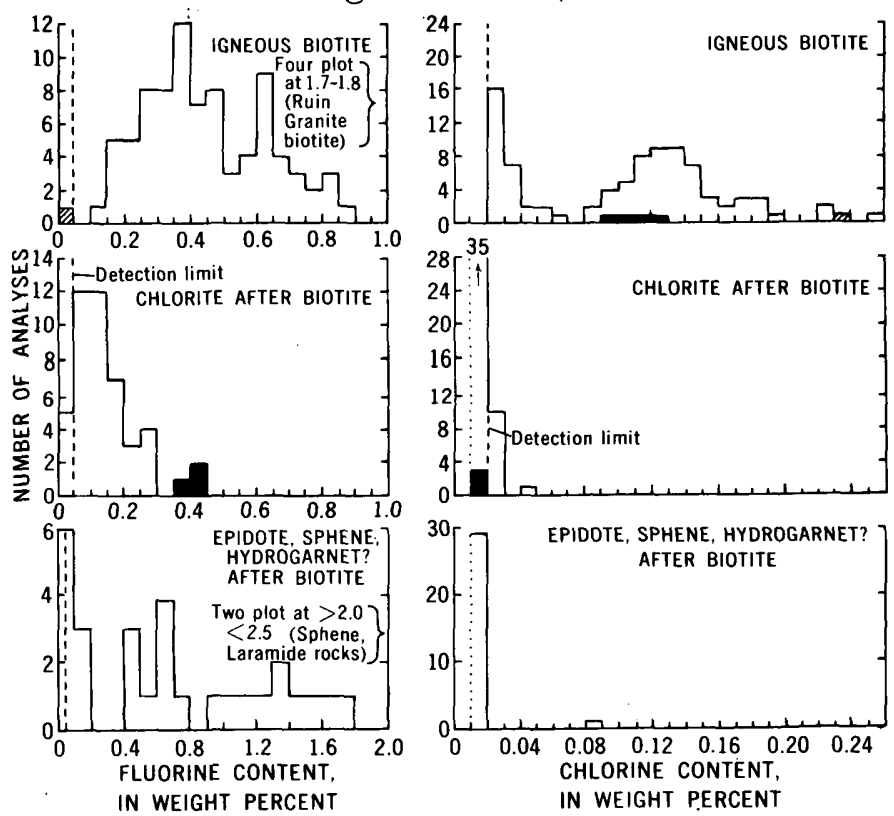

IN WEIGHT PERCENT

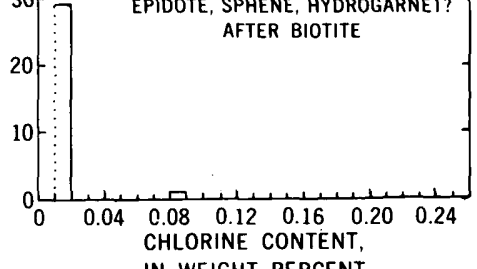
IN WEIGHT PERCENT

$\square$ Precambrian diabase $\square$ Precambrian Ruin Granite $\square$ Laramide intrusive rocks

Figure 13.-Frequency distribution of $\mathrm{F}$ and $\mathrm{Cl}$ of biotite and biotite alteration products. 
artifacts of different analytical procedures, or whether part of the biotite's $\mathrm{F}$ (like the $\mathrm{Cl}$ ) was removed from the rock during conversion of the biotite to alteration minerals.

Rock powders of all the samples were analyzed for $\mathrm{H}_{2} \mathrm{O}+$ (fig. 12A), and although these values also correlate negatively with rock differentiation index, the correlation is poorer than, for the calculated values of $\mathrm{H}_{2} \mathrm{O}+$ (fig. $12 C$, table 10 ). The poor correlation between figures $12 A$ and $12 C$ is somewhat improved by removing (by calculation) the effects of the hydrous alteration products in the samples (fig. $12 B$ ), and part of the remaining wide scatter in the points (fig. 12B) may be attributed to the more inhomogeneous distribution of the hydrous alteration products (containing as much as 12 percert $\mathrm{H}_{2} \mathrm{O}+$ by weight) compared to the hydrous igneous minerals (containing no more than 4 percent $\mathrm{H}_{2} \mathrm{O}+$ by weight). The arrow between the two filled squares (Tortilla Quartz Diorite, fig. 12B, $C$ ) represents the original $\mathrm{H}^{2} \mathrm{O}+$ content of sample 17-1, assuming that the fibrous amphibole (table 8 ) is (1) not igneous and replaces pyroxene (lower position) or (2) igneous or replacing hornblende (upper position). The statistics (table 10) were calculated assuming the former.

Simonen (1948), working with another consanguineous rock sequence, notes that more mafic rocks are richer in $\mathrm{Cl}$ than more silicic ones, and the data in Dodge and others (1968) show that rock $\mathrm{Cl}$ and $\mathrm{F}$ contents generally decrease with increasing differentiation index of the samples from the Sierra Nevada batholith. Thus, the findings at Ray are not unique. On the other hand, many conflicts are found in the literature. Correns (1956) found no correlation between the halogen contents and $\mathrm{SiO}_{2}$ contents of rocks when comparing samples from widely separated localities, where Goldschmidt (1954) and Simonen (1948) suggest that rock $\mathrm{F}$ contents increase with magmatic evolution of igneous series. Kuroda and Sandell (1953) and Correns (1956) found no correlation between rock composition and $\mathrm{Cl}$ content, whereas Behne (1953) suggests that felsic rocks contain more $\mathrm{Cl}$ than basic ones. It is suspected that some of these conflicts and exceptions to the findings at Ray may result in part from comparison of data compiled for rocks of differing origins, conditions of emplacement, and degrees of alteration. For example, the data in Simonen (1948) for petrochemically related rocks show, like the Ray rocks, little or no relation between rock chemistry and $\mathrm{F}$ content. Similarly, if plots like figure $11 \mathrm{~A}$ and $B$ had been made comparing the calculated $C l$ and $\mathrm{F}$ contents of the Ruin Granite at Ray (a Precambrian quartz monzonite) with those of the Granite
Mountain Porphyry (an Early Tertiary granodiorite), there would have resulted a strong positive correlation of the contents of $\mathrm{Cl}$ and $\mathrm{F}$ in the rock with increasing $\mathrm{SiO}_{2}$ content of the rocks. Clearly, because the Ruin Granite was emplaced as a batholith 1.4 b.y. prior to the Granite Mountain Porphyry (a stock), such plots would exceed their intended use. Thus the likelihood of constructing misleading geochemical trends for minor elements seems large if, in addition to a lack of time-space proximity of the rocks compared, the data are not corrected for the halogens and water introduced or lost during incipient alteration of the rock (fig. 13) or the halogens present in fluid inclusions and in salts deposited from ground water along microfractures (see table 15).

\section{APPLICATION TO PETROLOGIC MODELS}

The preceding data indicate that the abundances of the halogens and water in the igneous minerals studied have not been uniformly homogenized nor are they detectably controlled by changes in chemistry of the minerals, proximity or degree of local alteration, or potential susceptibility of a grain to exchange with the magma (s) or aqueous fluids. On the other hand, changes in abundance of $\mathrm{Cl}, \mathrm{F}$, and calculated $\mathrm{H}_{2} \mathrm{O}+$ in the igneous hydrous minerals appear to be related to changes in the age and chemistry of the parent magma(s). Similar trends are observed for minerals in other consanguineous igneous suites. These facts suggest that the hydrous igneous minerals studied at Ray probably retain an imprint of magmatic events and that the changes in the halogen and water contents of the minerals are more likely the result of changes in or initial differences between the magma(s) than the result of postmagmatic events. This interpretation is consistent with the resistance of fluorapatite to exchange with chloride-rich aqueous fluids (Ekström, 1973).

Given the interpretation that the changes in mole fractions of $\mathrm{Cl}, \mathrm{F}$, and $\mathrm{H}_{2} \mathrm{O}\left(X_{\mathrm{Cl}, \mathrm{F}, \mathrm{H}_{2} \mathrm{O}}\right)$ in the minerals probably reflect magmatic processes during development of the igneous suite at $\mathrm{Ray}$, it is of interest to petrology and current ideas about ore genesis if the data lead to the determination of how $X_{\mathrm{Cl}, \mathrm{F}, \mathrm{H}_{2} \mathrm{O}}$ varied in the melt(s) as the magmas became younger and more differentiated. Unfortunately, such a determination requires experimental data not yet availahle concerning the activity coefficients of $\mathrm{Cl}^{-}, \mathrm{F}^{-}$, and $\mathrm{OH}^{-}$, how the activity coefficient of each ion changes relative to the others with respect to temperature and pressure, and if and how the partition coefficients (between melt and mineral) of each ion change with temperature and pressure. Additionally, subjective deci- 
sions must be made as to whether the exposed plutons represent (1) sequential differentiates of one batholith while it was emplaced in the upper crust, (2) differentiates of several common source batholiths while they were emplaced in the upper crust, (3) as in 1 but occurring in the lower crust or upper mantle, (4) as in 2 but occurring in the lower crust or upper mantle, or (5) sequential or separate partial melts from a common source area.

It seems obvious that with so many possible variables, strong defense of any unique explanation for the data would be unwise. If explanations 2,4 , or 5 apply to Ray, then data need not be necessarily considered petrologic indicators of processes in differentiation of magma. However, the data for one magma (Rattler Granodiorite) are consistent with those for the entire igneous suite and, as cited earlier, with similar data for other igneous suites. Thus it seems at least reasonable to postulate that the trends observed in figures 8-10 could result from differentiation of a single magma and that evaluation of the magmatic behavior of $\mathrm{Cl}, \mathrm{F}$, and $\mathrm{H}_{2} \mathrm{O}$ is warranted. The following discussion concerns only explanation 1 above because of its significance to one current theory of ore genesis-that both ore and ore fluid components for porphyry copper deposits have their source in calcalkaline magma emplaced in the upper crust.

A long list of literature, reviewed in part by Lowell and Guilbert (1970), notes a time-space relation between intermediate calc-alkaline intrusive rocks and "disseminated" or porphyry copper ore deposits; this relation has generally been interpreted as causal. In the classical magmatic hypothesis of ore deposits, the calc-alkaline magmas are considered the vessels that transported the copper and sulfur to or near to the deposits, and there the magmas produced the mineralization through differentiation. However, in the Laramide plutons associated with Ray and also in those elsewhere in Arizona (Rehrig and Heidrick, 1972), mineralization is associated with a regional tectonic fracture system rather than with observed radial, concentric, and sheeting joints associated with cooling of the plutons. Thus, if the mineralizing fluids evolved according to the classical magmatic model, they must have come from deeper sources than the exposed plutons; that is, explanation 1 above, in which water is first concentrated through crystal differentiation in and later released from a nearby batholith. To facilitate transport of the ore and to explain the $\mathrm{NaCl}$ in fluid inclusions in porphyry deposits, the fluids released should preferably be rich in chloride (see for example, Helgeson, 1964; Garrels, 1941; Roedder, 1971).
This presumed late buildup of $\mathrm{Cl}$ and $\mathrm{H}_{2} \mathrm{O}$ was not recorded by the minerals in the exposed plutons associated with Ray (figs. 8-10, table 10). Thus, either the classical magmatic hypothesis does not apply to the Ray deposit, or it must be postulated that the minerals did not record the required processes in the batholith. Three models that might explain the data are presented below. The first two outline the processes and list the special conditions that apply if the rocks studied here are related to a nearby batholith that produced mineralizing fluids. The third model does not assume a classical magmatic origin for the Ray deposit.

\section{Changes imposed on the stocks}

If the classical magmatic hypothesis applies to Ray and if figures 8-10 depict directly how $X_{\mathrm{Cl}, \mathbf{F}, \mathbf{H}_{2} \mathrm{O}}$ varied in the melts of the exposed stocks, then the processes in the stocks did not follow those in the parent batholith. Because the stocks were emplaced at shallower depths than the batholith, it seems a reasonable postulate that they evolved water before the batholith did. Experimental studies (Koster van Groos and Wyllie, 1969; Wyllie and Tuttle, 1964) indicate that in a degassing melt, $\mathrm{Cl}$ would leave with $\mathrm{H}_{2} \mathrm{O}$ while most of the $\mathrm{F}$ would tend to remain in the melt (Burnham, 1967; Munoz and Eugster, 1969). Thus evolution of water from the ascending and crystallizing magmas of the exposed stocks would increase the activity of $\mathrm{F}$ in the melts of the stocks relative to the fugacity of water and the activity of chlorine while the batholith could continue to maintain and concentrate chlorine and water. However, several lines of evidence have already been discussed that are not consistent with the assumption that the exposed stocks saturated early in their crystallization history or evolved much water. To review, these are that: (1) biotite does not show a magnesium enrichment with decreasing age or with progressive differentiation of the stocks, (2) the percentage of aplites in the stocks is low, (3) pegmatitic aplites are sparse, (4) metamorphic aureoles around the intrusive rocks, both stocks and dikes, are restricted and in some places are virtually absent even in carbonate terrane, (5) miarolitic features or cavities have not been identified in field exposures or thin section samples of the Laramide stocks, and (6) the fluid inclusions in quartz in the rocks are sparse, two phase, and homogenize at temperatures considerably below the granite minimum. Also problematical to the postulate that evolution of Cl-bearing water explains the correlations of $X_{\mathrm{Cl}, \mathrm{F}, \mathbf{H}_{2} \mathrm{O}}$ in the minerals with rock chemistry and age are ex- 
perimental data (Munoz and Ludington, 1974; Munoz and Eugster, 1969). These data suggest that evolution of water at magmatic temperature from the stocks in amounts proportional to those required of the parent batholith to form the Ray deposit should have resulted, but did not (table 4), in (1) homogenization of $\mathrm{F}$ contents of biotite in individual samples and stocks and (2) higher F contents in the high-temperature igneous rather than in the lower temperature hydrothermal biotite. The fact that neither expectation is met requires that the igneous biotite had little contact with the water evolved at magmatic temperature and that the ore fluids had chemical parameters different from the water evolved from the stocks. In addition, the increase in $\mathrm{F}$ content of the biotites with increasing differentiation (fig. 9) is opposite to the trend expected because with vapor phase present, each of the following factors should have resulted in a decrease in the $\mathrm{F}$ content of biotite: (1) the $\mathrm{Mg}$ content of the biotite decreases with differentiation (see Ludington, 1973; Ekström, 1972; Munoz and Eugster, 1969; Munoz and Ludington, 1974; Wones and Eugster, 1965), (2) the F content of the rock decreased or remained the same during differentiation (fig. $11 B$; see also Munoz and Eugster, 1969), and (3) presumably the temperature of the differentiating magma $(\mathrm{s})$ and its evolving vapor phase(s) would be progressively lower (see Munoz and Eugster, 1969). Thus, an additional requirement on the evolving water $(\mathrm{s})$ is that they became progressively enriched in $F$ as the host rock became more felsic despite the observed decrease of $\mathrm{F}$ content of the rock (fig. $11 B$ ) and probable decrease in temperature of the magma. As an alternative to this, it could be postulated that the Tortilla Quartz Diorite and Rattler Granodiorite did not evolve much water whereas the Granite Mountain Porphyry evolved much more water that, for some reason, resulted in higher contents of and homogenization of $\mathrm{F}$ in individual biotite grains of the Granite Mountain Porphyry without homogenizing the grains with respect to the other elements or with respect to $\mathrm{F}$ contents of biotite in adjacent grains and in other samples from the stock. Finally, at their depths of emplacement, the stock should have saturated at between 2.5 to more than 3.5 wt percent $\mathrm{H}_{2} \mathrm{O}$ (Burnham, 1967); this is about the approximate amount required in the melts for biotite to form in the stocks (D. R. Wones, oral commun., 1974; Wones and Dodge, 1966). Thus, if it is postulated that the magmas evolved water while ascending or during the main stage of crystallization, disequilibrium crystallization also must be postulated.
Taken alone, any one of the foregoing requirements and observations does not preclude the possibility that the character of the magmas of the stocks changed through evolution of water and chlorine. However, with so many requirements on the presumed aqueous phase(s) and with the popular desire for simplicity and consistency in interpretation of data, alternative explanations of the trends with age and chemistry indicated in figures 8-10 seem warranted. Another model that maintains the assumptions of the classical magmatic model is given below.

\section{End-stage degassing of the stocks and batholith}

This model drops the requirement that the stocks evolved water during their ascent and main-stage crystallization but maintains the requirement of the classical magmatic model that chloride-rich water was produced at or near the end of differentation of the parent batholith (and also of its effluent stocks). However, like the preceding one, this model finds the same problems with the paucity or even negative physical evidence that water in the volumes proportional to those required for the deposit evolved from the stocks at magmatic temperatures. It also requires the same special conditions to explain the lack of magnesium enrichment in biotite from aplites of the stocks and why the biotite did not respond chemically to presence of the evolving magmatic water. In addition, the failure of $X_{\mathrm{Cl}, \mathrm{H}_{2} \mathrm{O}}$ in the minerals to record the buildup of $X_{\mathrm{Cl}, \mathrm{H}_{2} \mathrm{O}}$ in the parent batholith means that to explain figures $8-10$, changes in the activities of $\mathrm{Cl}^{-}$, $\mathrm{F}^{-}$, and $\mathrm{OH}^{-}$(or fugacity of $\mathrm{H}_{2} \mathrm{O}$ ) in the melt do not directly record changes in $X_{\mathrm{Cl}, \mathrm{F}, \mathrm{H}_{2} \mathrm{O}}$ in the melt. This model cannot be evaluated further without experimental data that indicates that activity of $\mathrm{F}$ can in fact increase relative to the activities of both water and chlorine in a differentiating melt while $X_{\mathrm{F}}$ in the melt (probably very close to figure $11 B$ ) remains roughly constant or decreases and while $X_{\mathrm{Cl}}$ and $X_{\mathrm{H}_{2} \mathrm{O}}$ in the melt increase.

\section{Magmatic evolution through crystal differentiation}

This model postulates that the magmas were undersaturated in water when emplaced at the present levels of exposure, that the precipitation of hydrous minerals controlled the activities of $\mathrm{Cl}, \mathrm{F}$, and $\mathrm{H}_{2} \mathrm{O}$ in the melt, and, as a consequence of these postulates and the petrologic evidence indicating that the hydrous minerals continued to form late in the crystallization history of the stocks, that the magmas evolved very little water. The paucity of evolved water is consistent with fluid-inclusion data, lack of miarolitic features in 
stocks, paucity of pegmatitic dikes, low percentage of aplites, lack of $\mathrm{Mg}$ enrichment in the igneous biotite, and restricted skarn development associated with the plutons. It is also consistent with the F chemistry of the biotite. This interpretation of the data does not preclude the possibility that water evolved from the magmas after the hydrous minerals ceased forming, perhaps after other components required for formation of the hydrous minerals were consumed or perhaps in response to local disequilibrium. In fact, the presence of interstitial epidote in the stock suggests that fugacity of $\mathrm{H}_{2} \mathrm{O}$ in the stocks did increase locally during the very final stages of crystallization. However, in this model the water evolved was probably small in amount and low in $\mathrm{Cl}$ content.

If the magmas were originally undersaturated and evolved only insignificant amounts of water relative to the total volumes of the stocks, then the trends observed between the age and chemistry of the rock and the abundances of $\mathrm{Cl}, \mathrm{F}$, and $\mathrm{H}_{2} \mathrm{O}+$ in the minerals (figs. 8-10) must be explained by crystal differentiation, whereby most of the $\mathrm{Cl}, \mathrm{F}$, and $\mathrm{H}_{2} \mathrm{O}$ originally present in each magma was extracted from the melts by the hydrous minerals. In this model then, changes in activities of $\mathrm{Cl}^{-}, \mathrm{F}^{-}$, and $\mathrm{OH}^{-}$(as indicated in figs. 8-10) were proportional to changes of $X_{\mathrm{Cl}^{-}, \mathrm{F}^{-}, \mathrm{OH}^{-}}$in the melt (as indicated in figs. $11 \mathrm{~A}$, $B ; 12 C)$. Thus, for the Rattler Granodiorite, the first hydroxyl-bearing minerals that separated from the magma tended to incorporate more chlorine relative to water and fluorine, and more water relative to fluorine than hydroxyl-bearing minerals that separated at a later time or from the more differentiated magma. If all the stocks came from the same nearby batholith (questionable that it would remain molten for 10 m.y. in the shallow crust) or deep batholith (where heat input might lengthen the life of the batholith), then the explanation applied to the Rattler Granodiorite applies to the entire igneous suite.

As with the preceding model, there is no direct experimental justification or refutation for this explanation of the data. However, $\mathrm{F}$ is much more soluble in silica-rich melts than both $\mathrm{H}_{2} \mathrm{O}$ and $\mathrm{Cl}$, and $\mathrm{H}_{2} \mathrm{O}$ is more soluble than $\mathrm{Cl}$ (Koster van Groos and Wyllie, 1968,1969 ; Burnham, 1967). Thus given the assumption that less soluble components would tend to leave the melt prior to more soluble components, this model, although not irrefutably supported, is at least consistent with the experimentally determined relative solubilities of $\mathrm{Cl}, \mathrm{F}$, and $\mathrm{H}_{2} \mathrm{O}$ in silicate melts.

Failure of the outer edges of the mineral grains consistently to record the postulated progressive depletion of $\mathrm{Cl}$ and $\mathrm{H}_{2} \mathrm{O}$ in the melts relative to $\mathrm{F}$ may be at- tributed to (1) inhomogeneities in the melt, (2) convective mixing of the grains, or (3) in-place variations of conditions controlling halogen uptake. The first of these alternatives is favored because it seems likely that with several coexisting hydrous phases simultaneously consuming volatiles from the melt in different amounts and at different rates, and with the nearby anhydrous minerals simultaneously rejecting and thus reconcentrating them at different rates, it seems reasonable to postulate that the diffusion rates of all components were not adequate to maintain, on a local scale, a homogeneous melt with respect to $\mathrm{Cl}, \mathrm{F}$, and $\mathrm{H}_{2} \mathrm{O}$. The larger intragrain and intrasample variation of $\mathrm{Cl}$ and $\mathrm{F}$ in apatite relative to the biotite, hornblende, and sphene might also be explained by inhomogeneities in the melts because the demands by apatite for $\mathrm{Cl}$ and $\mathrm{F}$ in the melt were greater and thus less likely to be fulfilled at a consistent ratio of $\mathrm{Cl}: \mathrm{F}: \mathrm{H}_{2} \mathrm{O}$ compared to those of the hydrous silicates. The two alternative explanations offered above do not seem as likely because one should expect the biotite, hornblende, and sphene to have recorded variations in halogen abundances similar to those observed in the apatite, if either convective mixing or in-place variation of $P_{\mathrm{H}_{2} \mathrm{O}}, T$, or $P_{\text {total }}$ were the major cause of the observed intrasample and intragrain variations. Further, it is difficult to visualize mechanisms that would change $P_{\mathrm{H}_{2} \mathrm{O}}, T$, and $P_{\text {total }}$ on a millimetre scale or ways in which adjacent grains might have moved over the distances required to cause the observed differences in halogen contents, both within and between grains, in the samples that were possibly 50-80 percent crystallized prior to formation of hydrous minerals.

This model requires that the melts arrived at their level of emplacement not only undersaturated but carrying not much more than 1-0.5 percent $\mathrm{H}_{2} \mathrm{O}$ by weight (mafic and felsic stocks, respectively), or in other words, the hydrous minerals could not begin to form in the magmas until about 50 percent of the mafic magmas and about 80 percent of the felsic magmas had crystallized. This is consistent with petrologic observations and interpretations for most of the samples but not with those for the rhyodacite dikes and the porphyritic facies of the Rattler Granodiorite where the presence of phenocrysts suggests the possible onset of hydrous mineral formation when less than $30-50$ percent of the magma (s) had crystallized. Thus, if the above model is to explain the data, either some of the magmas (and part of the Rattler Granodiorite magma) had two to three times more water initially. or water was locally concentrated in or introduced into some of the magmas. For example, the porphyritic facies of the Rattler Granodiorite may have gained water from the 
rest of the melt because of diffusion of water to cooler parts of the melt (Kennedy, 1955), thereby enriching one part of the melt in water at the expense of the other prior to formation of the groundmass minerals. However, under conditions of small concentration gradients, diffusion of water in melts may be slow (Burnham, 1967), and instead, a convecting or turbulent part of the magma exposed to wet wallrocks may have stripped water from the wallrocks in a manner similar to metallurgic zone refining (Shaw, 1972; Harris, 1957). A final special condition required for this model concerns sample $60-113 \mathrm{D}$ ( $\mathrm{D}$ of figs. $8-10$ ), a dike that intrudes both the porphyritic and nonporphyritic facies of the Rattler Granodiorite prior to development of aplites in the stock. Biotite and hornblende in this dike contain more $\mathrm{Cl}$ than biotite and hornblende in rocks cut by the dike. Possible explanations for this relation are (a) turbulent flow in the dike caused "stripping" of $\mathrm{Cl}$ and $\mathrm{H}_{2} \mathrm{O}$ of meteoric or magmatic. origin from the nearly crystallized parts of the stock, (b) the dike represents a late resurgence from an unconsolidated deeper and less differentiated part of the stock or (c) the dike represents an intrusion that was not part of the Rattler Granodiorite magma.

\section{Concluding remarks}

The last of the three models discussed in this section is thought to be consistent with more data and to require fewer unprovable special conditions than the first two models, but no one model can be considered the unique explanation of the data, particularly if all stocks and dikes did not originate from a nearby batholith. Although the first two models do not incorporate all the field, chemical, and existing experimental observations as favorably as the last, neither they nor a classical magmatic genesis for Ray can be ruled out with certainty. On the other hand, the data for the Ray rocks neither require nor support the classical magmatic origin of the Ray deposit, and they are similar to those for plutons that are not associated with porphyry copper deposits. Thus a source alternative to an upper crustal batholith might profitably be sought to explain the mineralization at Ray and perhaps other deposits.

\section{BIOTITE AS A PARTIAL OR SUPPLEMENTARY SOURCE OF CHLORINE AND FLUORINE IN THERMAL WATERS}

\section{Chlorine}

The distribution of $\mathrm{Cl}$ between igneous biotite and its propylitic type alteration products at Ray (fig. 13) suggests that natural thermal waters and ore fluids might find a partial or supplementary source of $\mathrm{Cl}$ in that released during alteration of biotite to chlorite, epidote, and sphene. For example, upon alteration of 20 percent of the biotite (comprising an average of more than 7 volume percent of the rock), each cubic kilometre of average Laramide igneous rock $(\rho \approx 2.8$ $\mathrm{g} / \mathrm{cm}^{3}$ ) at Ray, using the average $\mathrm{Cl}$ abundance of biotite $(1,100 \mathrm{ppm})$ analyzed here, would release as much as $4 \times 10^{10} \mathrm{~g} \mathrm{Cl}$ to the altering fluid if the average biotite alteration product contained $\mathrm{Cl}$ in amounts just below detection $(200 \mathrm{ppm})$. If the average alteration product contained $\mathrm{Cl}$ in amounts considerably below detection levels (contents of $20-30 \mathrm{ppm}$ ), $4.8 \times 10^{10}$ $\mathrm{g} \mathrm{Cl}$ would be released to the fluids.

This does not imply that the major source of $\mathrm{Cl}$ in natural hot waters is altered biotite because much might be trapped in fluid inclusions or in alteration products of the feldspars. For example, if the observed modal phengite and clay (both containing no more than $200 \mathrm{ppm} \mathrm{Cl}$ ) had developed in the coexisting plagioclase and $\mathrm{K}$-feldspar during the period of biotite destruction, only $1.3 \times 10^{10}$ to $1.8 \times 10^{10} \mathrm{~g} / \mathrm{km}^{3} \mathrm{Cl}$ would still be available for incorporation in fluid inclusions or for further transport in the fluid phase. This does not rule out the possibility that alteration of biotite might be a supplementary or partial source of $\mathrm{Cl}$ in hydrothermal fluids, particularly if the hydrous alteration products of plagioclase contain significantly less $\mathrm{Cl}$ than that detectable by methods used here (200 ppm) or if the plagioclase alteration occurred at a different time than the biotite alteration.

\section{Fluorine}

Chloritization of the igneous biotite in the Laramide rocks at Ray was accompanied by development of anhedral sphene, epidote, and perhaps even the $\mathrm{F}$-bearing hydrogarnet(?) (in decreasing order of abundance). The sphene and hydrogarnet(?) contain $\mathrm{F}$ in abundances usually greater than the host biotite (fig. 13, compare tables 4 and 8 ) suggesting that much of the $F$ in the biotite was immediately reprecipitated. However, if data in table 15 apply, only part of the F originally in the biotite remained in the rock (compare $\mathrm{F}^{\mathrm{b}}$ with $\mathrm{F}^{\mathrm{c}}$ in table 15). Thus, it seems possible that biotite could also provide some $\mathrm{F}$ to waters that cause propylitic alteration, particularly in instances where the calcium content of the waters is low, and epidote and sphene do not form in biotite during the alteration.

\section{REFERENCES CITED}

Banks, N. G., 1974, Distribution of copper in biotite and blotite alteration products in intrusive rocks near two Ar1zona porphyry copper deposits: U.S. Geol. Survey Jour. Research, v. 2, p. 195-212. 
Banks, N. G., Cornwall, H. R., Silberman, M. L., Creasey, S. C., and Marvin, R. F., 1972, Chronology of intrusion and ore deposition at Ray, Arizona-Part I, K-Ar ages: Econ. Geology, v. 67, p. 864-878.

Banks, N. G., and Stuckless, J. S., 1973, Chronology of intrusion and ore deposition at Ray, Arizona-Part II, flssion-track ages: Econ. Geology, v. 68, p. 657-664.

Beaman, D. R., and Isasi, J. R., 1970, A critical review of computer programs used in quantitative electron microprobe analysis: Anal. Chemistry, v. 42, p. 1540-1568.

Beeson, M. H., 1967, A computer program for processing electron microprobe data: U.S. Geol. Survey open-flle rept., $40 \mathrm{p}$.

Behne, W., 1953, Untersuchungen zur Geochemie des Chlor und Brom: Geochim. et Cosmochim. Acta, v. 3, p. 186-215.

Birks, L. S., 1963, Electronprobe microanalysis: New York, John Wiley and Sons, $253 \mathrm{p}$.

Burnham, C. W., 1967, Hydrothermal fluids at the magmatic stage, in Barnes, H. L., ed., Geochemistry of hydrothermal ore deposits: New York, Holt, Rinehart, and Winston, p. 34-76.

Cornwall, H. R., Banks, N. G., and Phillips, C. H., 1971, Geologic map of the Sonora quadrangle, Pinal and Gila Counties, Arizona: U.S. Geol. Survey Geol. Quad. Map GQ-1021, scale 1:24,000.

Cornwall, H. R., and Krieger, M. H., 1975, Geologic map of the Kearny quadrangle, Pinal County, Arizona: U.S. Geol. Survey Geol. Quad. Map GQ-1188, scale 1:24,000. (In press.)

Correns, C. W., 1956, The geochemistry of the halogens: Physics and Chemistry of the Earth, v. 1, p. 181-233.

Dodge, F. C. W., and- Moore, J. G., 1968, Occurrence and composition of biotites from the Cartridge Pass pluton of the Sierra Nevada batholith, California, in Geological Survey research 1968: U.S. Geol. Survey Prof. Paper 600-B, p. B6-B10.

Dodge, F. C. W., Papike, J. J., and Mays, R. E., 1968, Hornblendes from granitic rocks of the central Sierra Nevada batholith, California: Jour. Petrology, v. 9, p. 378-410.

Dodge, F. C. W., and Ross, D. C., 1971, Coexisting hornblendes and biotites from granitic rocks near the San Andreas fault, California: Jour. Geology, v. 79, p. 158-172.

Dodge, F. C. W., Smith, V. C., and Mays, R. E., 1969, Biotites from granitic rocks of the central Sierra Nevada batholith, California : Jour. Petrology, v. 10, p. 250-271.

Ekström, T. K., 1972, The distribution of fluorine among some coexisting minerals: Contr. Mineralogy and Petrology, v: 34, p. 192-200.

- 1973, Synthetic and natural chlorine-bearing apatite: Contr. Mineralogy and Petrology, v. 38, p. 329-338.

Garrels, R. M., 1941, The Mississippi Valley type lead-zinc deposits and the problem of mineral zoning: Econ. Geology, v. 36, p. 729-744.

Gillberg, M., 1964, Halogens and hydroxl contents of micas and amphiboles in Swedish granitic rocks: Geochim. et Cosmochim. Acta, v. 28, p. 495-516.

Goldschmidt, V. M., 1954, Geochemistry, edited by Alex Muir : London, Oxford Clarion Press, $730 \mathrm{p}$.

Harris, P. G., 1957, Zone refining and the origin of potassic basalts: Geochim. et Cosmochim: Acta, v. 12, p. 195-208.

Helgeson, H. C., 1964, Complexing and hydrothermal ore deposition : New York, MacMillan, $128 \mathrm{p}$.
Ivanov, V. S., 1971, Composition of biotite in granitoids, as influenced by temperature and chemical activity of potassium : Internat. Geology. Rev., v. 13, no. 5, p. 649-657.

Jackson, E. D., Stevens, R. E., and Bowen, R. W., 1967, A computer-based procedure for deriving mineral formulas from mineral analyses, in Geological Survey research 1967 : U.S. Geol. Survey Prof. Paper 575-C, p. C23-C31.

Jahns, R. H., and Tuttle, O. F., 1963, Origin of igneous aplites [abs.] : Geol. Soc. America Spec. Paper 73, p. 177-178.

Kennedy, G. C., 1955, Some of the aspects of the role of water in rock melts: Geol. Soc. America Spec. Paper 62, p. 489-503.

Koster van Groos, A. F., and Wyllie, P. J., 1968, Melting relationships in the system $\mathrm{NaAlSi}_{3} \mathrm{O}_{8}-\mathrm{NaF}-\mathrm{H}_{2} \mathrm{O}$ : Jour. Geology, v. 76, p. 50-70.

1969, Melting relationships in the system $\mathrm{NaAlSi}_{3} \mathrm{O}_{5}-$ $\mathrm{NaCl}-\mathrm{H}_{2} \mathrm{O}$ at one kilobar pressure, with petrological applications: Jour. Geology, v. 77, p. 581-605.

Kuroda, P. K., and Sandell, E. B., 1953, Chlorine in igneous rock, some aspects of the geochemistry of chlorine: Geol. Soc. America Bull., v. 64, p. 879-896.

Lee, D. E., and Van Loenen, R. E., 1970, Biotites from hybrid granitoid rocks of the southern Snake Range, Nevada, in Geological Survey research 1970: U.S. Geol. Survey Prof. Paper 700-D, p. D196-D206.

Lowell, J. D., and Guilbert, J. M., 1970, Lateral and vertical alteration-mineralization zoning in porphyry ore deposits: Econ. Geology, v. 65, p. 373-408.

Ludington, S. D., 1973, Refinement of the biotite-apatite geothermometer [abs.]: Geol. Soc. America, Rocky Mountain Sec., Abstracts with Programs, v. 5, no. 6, p. 493-494.

Munoz, J. L., and Eugster, H. P., 1969, Experimental control of fluorine reactions in hydrothermal systems: Am. Mineralogist, v. 54, p. 943-959.

Munoz, J. L., and Ludington, S. D., 1974, Fluoride-hydroxyl exchange in biotite: Am. Jour. Sci., v. 274, p. 396-413.

Nash, W. P., 1972a, Apatitecalcite equilibria in carbonatitechemistry of apatite from Iron Hill, Colorado: Geochim. et Cosmochim. Acta, v. 36, p. 1313-1319.

1972b, Apatite chemistry and phosphorus fugacity in a differentiated igneous intrusion: Am. Mineralogist, v. 57, p. $877-886$.

Rehrig, W. A., and Heidrick, T. L., 1972, Regional fracturing in Laramide stocks of Arizona and its relationship to porphyry copper mineralization: Econ. Geology, v. 67, p. 198-213.

Roedder, Edwin, 1971, Fluid inclusion studies on the porphyry-type ore deposits at Bingham, Utah, Butte, Montana, and Climax, Colorado: Econ. Geology, v. 66, p. 98118.

Roegge, J. S., Logsdon, M. J., Young, H. S., Barr, H. B., Borcsik, M., and Holland, H. D., 1974, Halogens in apatites from Providencia area, Mexico: Econ. Geology, v. 69, p. 229-240.

Shaw, D. M., 1972, Development of the early continental crust-Part 1, use of trace element distribution coefficient models for the Protoarchean crust: Canadian Jour. Earth Sci., v. 9, p. 1577-1595.

Simonen, Ahti, 1948, On the petrology of the Aulanko area in southwestern Finland: Finlande Comm. Géol. Bull. 143, p. 1-66. 
Stormer, J. C., and Carmichael, I. S. E., 1971, Fluorine-hydroxyl exchange in apatite and biotite-A potential igneous geothermometer: Contr. Mineralogy and Petro$\log y$, v. 31, p. 121-131.

Taborszky, F. K., 1962, Geochemie des apatits in Tiefgesteinen am Beispiel des Odenwaldes: Beitr. Mineralogie u. Petrographie, v. 8, p. 354-392.

Thornton, C. P., and Tuttle, O. F., 1960, Chemistry of igneous rocks-I, Differentiation index: Am. Jour. Sci., v. 258, p. 664-684.

Wones, D. R., and Dodge, F. C. W., 1966, On the stability of phlogopite [abs.]: Geol. Soc. America and assoclated societies, Ann. Mtg., San Francisco, Calif., 1966, Program, p. 243.

Wones, D. R., and Eugster, H. P., 1965, Stability of biotite; Experiment, theory and application: Am. Mineralogist, v. 50, p. 1228-1272.

Wyllie, P. J., and Tuttle, O. F., 1964, Experimental investigation of silicate systems containing two volatile components-Part III, the effects of $\mathrm{SO}_{3}, \mathrm{P}_{2} \mathrm{O}_{5}, \mathrm{HCl}$, and $\mathrm{LiO}_{2}$, in addition to $\mathrm{H}_{2} \mathrm{O}$, on the melting temperatures of albite and granite: Am. Jour. Sci., v. 262, p. 930-939. 

Jour. Research U.S. Geol. Survey

Vol. 4, No. 1, Jan.-Feb. 1976, p. 119-125

\title{
BOOTSTRAP WINDOW, ELKO AND EUREKA COUNTIES, NEVADA
}

\author{
By JAMES G. EVANS and THOMAS E. MULLENS, \\ Menlo Park, Calif., Denver, Colo.
}

\begin{abstract}
The Bootstrap window in the Roberts Mountains thrust of north-central Nevada contains a 1,500-ft (460-m)thick autochthonous section of carbonate assemblage rocks. These carbonate rocks include the upper part of the Roberts Mountains Formation and an unnamed limestone of Devonian age. They contain abundant material that must have been deposited in or near a reef. Allochthonous chert and shale of the siliceous assemblage, presumably Ordovician and Silurian in age, are present around the window and in a north-trending graben within the window.

The Paleozoic rocks contain altered dikes, most of which may originally have been granodioritic. The localized recrystallization in the Paleozoic rocks probably occurred during dike emplacement. Sometime after the intrusion; both the dikes and their host rocks. were epithermally altered. Some gold has been mined, and relatively high gold values ( $\geqq 1 \mathrm{ppm}$ ) occur in rocks of the siliceous assemblage in and near the northern part of the steep north-trending fault zone on the west side of the graben. Areas of secondary alteration and of high values of silver and mercury are more widespread than the area of high gold values. The highest concentrations of silver and mercury, however, are also found near the same gold-bearing fault zone.
\end{abstract}

A major geologic structure in north-central Nevada, the Roberts Mountain thrust, separates autochthonous carbonate rocks of the lower plate, generally called the eastern assemblage, and allochthonous siliceous rocks of the upper plate, generally called the western assemblage. The upper plate was emplaced during the Late Devonian and Early Mississippian Antler orogeny. Since that time, localized doming and upfaulting of the early and middle Paleozoic sedimentary rocks involved in the thrusting, accompanied by erosion, have formed windows in the Roberts Mountains thrust. In the southern Tuscarora Range three such windows, the Carlin, Lynn, and Bootstrap, are alined northwest-southeast (fig. 1).

The Bootstrap window, the northwesternmost window, covers about $1 \mathrm{mi}^{2}\left(2.6 \mathrm{~km}^{2}\right)$ and lies astride the Elko-Eureka County line. A well-graded dirt road between Interstate 80 near Dunphy Ranch and the Rossi mine, $3 \mathrm{mi}(4.8 \mathrm{~km})$ north of the Bootstrap window, passes along the west side of the window.
The Bootstrap window (fig. 2) is surrounded on three sides by chert and shale of the siliceous assemblage and lies on the east edge of the late Miocene and early Pliocene volcanic flows of the Sheep Creek Range (see Roberts and others, 1967; McKee and Silberman, 1970). Although the Bootstrap window is the northwesternmost window known, the autochthonous carbonate assemblage shows no signs of grading into the allochthonous siliceous assemblage. In fact, the carbonate rocks are mainly reeflike limestone and do not fit the commonly accepted (Roberts and others, 1967; Stewart and Poole, 1974) concept of westward gradation to rocks deposited in deeper water.

\section{DESCRIPTIONS OF THE ROCK UNITS}

\section{Carbonate Assemblage}

\section{General features}

About 1,500 ft $(460 \mathrm{~m})$ of carbonate rock exposed on the west side of Round Mountain (fig. 2) includes the upper $590 \mathrm{ft}(180 \mathrm{~m})$ of the Roberts Mountains Formation and about $900 \mathrm{ft}(275 \mathrm{~m})$ of unnamed Devonian limestone. The contact between the two rock units was not drawn on the geologic map because it cannot be readily traced south and north of the wellexposed section. On the west side of Round Mountain the contact is at the 5,500-ft contour and trends northsouth for about $2,000 \mathrm{ft}(610 \mathrm{~m})$.

\section{Roberts Mountains Formation}

The lowermost $590 \mathrm{ft}(180 \mathrm{~m})$ of the section on the west side of Round Mountain is mixed silty dolomitic laminated limestone and coarse-grained limestone in the ratio $4: 1$. Beds of black chert $1-2$ in. $(2.5-5 \mathrm{~cm})$ thick occur within the laminated limestone. The beds of laminated and thick-bedded coarse-grained limestone range in thickness from a few inches (several centimetres) to $60 \mathrm{ft}(18.3 \mathrm{~m})$. The thickest zones of coarse-grained limestone are about $30 \mathrm{ft}(9 \mathrm{~m})$ thick. 


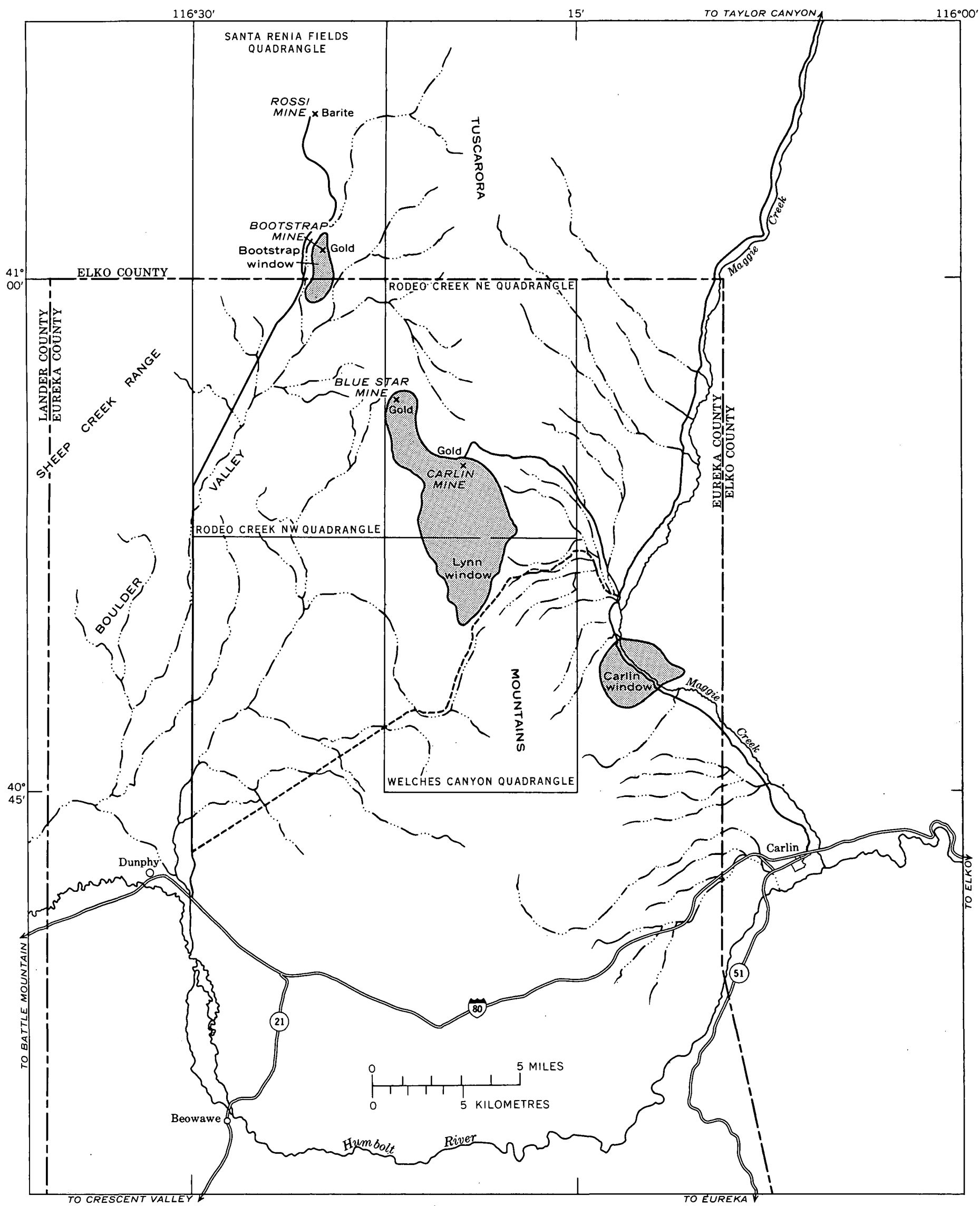

Froore 1.-Index map showing location of the Bootstrap window in north-central Nevada. 

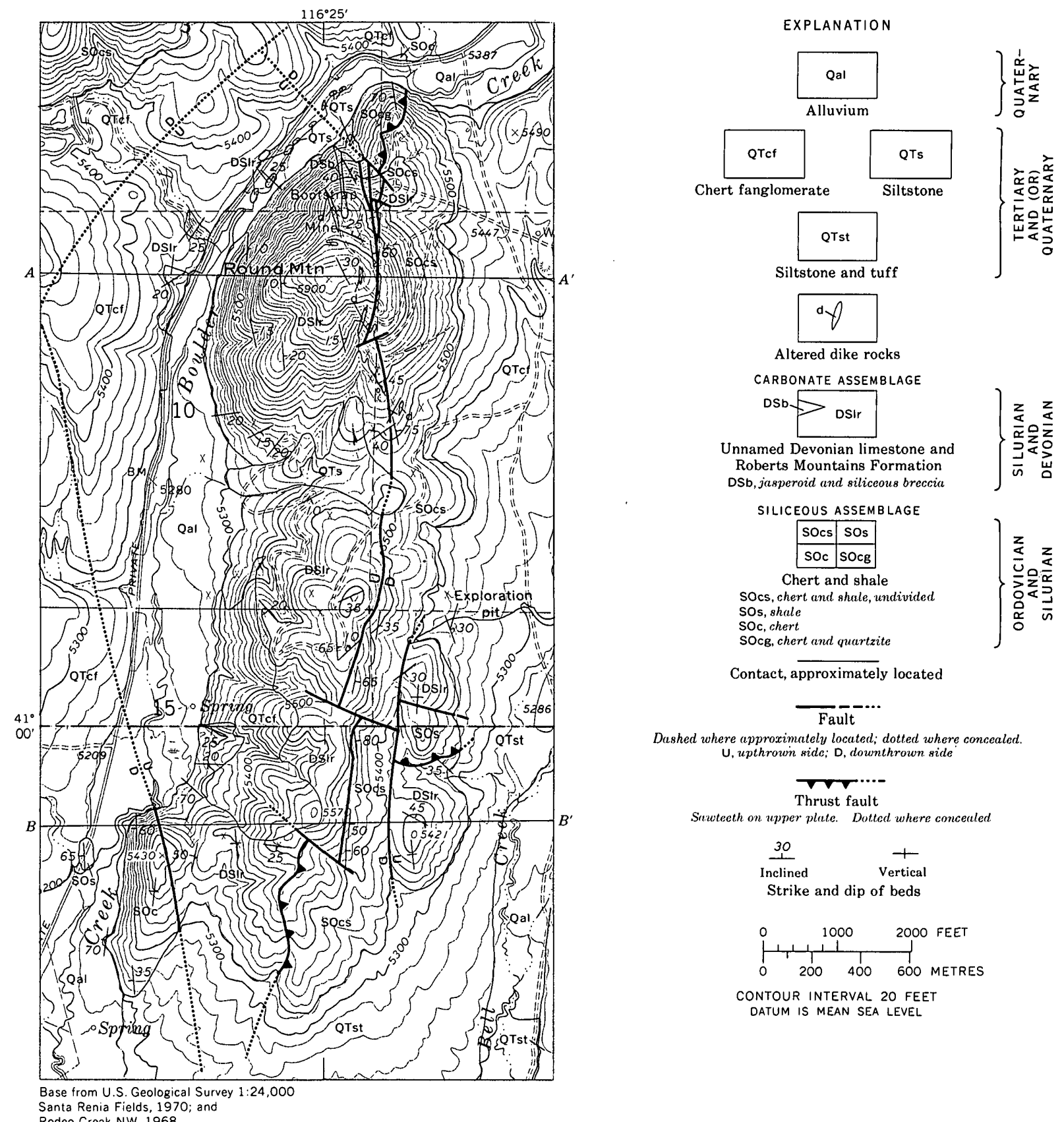

SILICEOUS ASSEMBLAGE

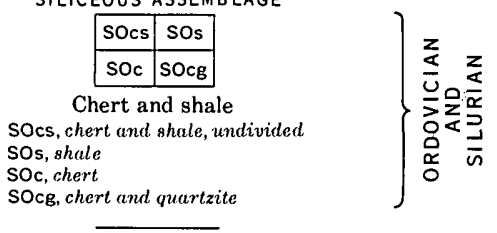

Contact, approximately located

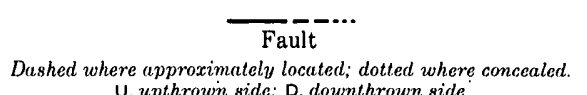

$\mathrm{U}$, upthrown side; $\mathrm{D}$, downthrown side

Thrust fault

Suwtecth on upper plate. Dotted where conceuled

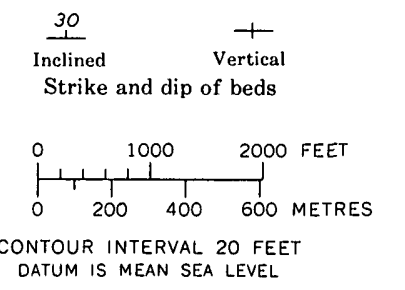

(15ET)

Frgure 2.-Geologic map and sections of Bootstrap window.

Many of the coarse-grained beds have scour surfaces, bioclastic debris (corals, stromatoporoids, brachiopods, and algae), angular fragments of coarse-grained pelletal limestone, and graded bedding. Such beds were probably deposited as debris flows from a reef.
The laminated limestone both in the Roberts Mountains Formation and in the overlying unnamed Devonian limestone has similar compositions. The laminated limestone samples studied show a wide variation in the proportions of major mineral constituents: cal- 
cite $10-60$ percent; dolomite $20-50$ percent; quartz (largely detrital) 15-35 percent; and clay (chiefly illite with minor kaolinite) $5-15$ percent. Potash feldspar (1-8 percent) is a minor constituent. Plagioclase, iron oxide, collophane, zircon, tourmaline, and chlorite occur in trace amounts.

Brachiopod collections, probably from the lower part of the limestone section, were identified by Boucot and Johnson as closely resembling collections within the Roberts Mountains Formation in the Roberts Mountains (Roberts and others, 1967, p. 119-120). Collections of graptolites and conodonts from the lower $600 \mathrm{ft}(184 \mathrm{~m})$ of the section range in age from Middle Silurian to Early Devonian (T. E. Mullens, unpub. data.). Monograptus uniformis Pribyl, which defines the lowest graptolite zone within the Devonian System, occurs $570 \mathrm{ft}(174 \mathrm{~m})$ above the base of the carbonate section. The contact of the Roberts Mountains Formation and the unnamed Devonian limestone is $20 \mathrm{ft}(6.1 \mathrm{~m})$ higher than this graptolite locality and at the base of the predominantly coarse-grained limestone part of the section.

\section{Unnamed Devonian limestone}

The upper $900 \mathrm{ft}(275 \mathrm{~m})$ of the carbonate section is mainly coarse-grained limestone; it includes less than 5 percent laminated limestone identical to the characteristic lithology of the underlying Roberts Mountains Formation. The thickest zone of the laminated limestone occurs in the lowermost $100 \mathrm{ft}(30.5$ $\mathrm{m}$ ) of the Devonian limestone and is $10 \mathrm{ft}(3 \mathrm{~m})$ thick. The thick-bedded coarse-grained limestone is as much as $40 \mathrm{ft}(12.2 \mathrm{~m})$ thick between thin $(<1 \mathrm{ft}$, or $0.3 \mathrm{~m})$ zones of laminated limestone. Some of the coarsegrained limestone contains pelmatozoan stems and fragments of algae, bryozoa, and corals.

Most of the coarse-grained limestone is pelletal to oolitic. Pellets of very fine grained dirty calcite, ranging in diameter from 0.1 to $1.5 \mathrm{~mm}$ (average $0.3 \mathrm{~mm}$ ), form more than 50 percent of the limestone and are locally deformed into irregular shapes by compaction.

The coarse-grained limestone is predominantly calcite, $60-90$ percent, and also contains quartz, 10-35 percent. Most of the quartz is authigenic and replaces calcite in pellets, occurs in fractures in clear calcite grains and in the pellets, and forms euhedral grains up to $0.1 \mathrm{~mm}$ across. A little of the quartz is angular to rounded detrital grains that locally are partly replaced by calcite. Dolomite and clay, chiefly illite, are minor constituents. Accessory minerals in some samples include potassium feldspar, iron oxides, collophane, zircon, and tourmaline.
The collection of conodonts from the highest beds in the section, on the east side of Round Mountain near the crest, contained Spathognathodus remscheidensis Ziegler, whose presence indicates an Early Devonian age (J. W. Huddle, written commun., 1971).

\section{Alteration and recrystallization}

The silty laminated limestone is locally considerably altered by hydrothermal action. The alteration includes leaching of carbonate, hematitic and argillic alteration, quartz veining, and silicification (fig. 3). The end product of altering the laminated limestone is a partly silicified, light-brown, yellow, and red siltstone that locally contains conspicuous zones of jasperoid and jasperoid breccia. The coarse-grained limestone was not altered as much as the silty laminated limestone. Recrystallized limestone occurs on the north end of the Bootstrap window. There the limestone, which is probably part of the unnamed Devonian limestone, was changed into an interlocking mosaic of very coarse calcite grains locally more than 0.4 in. $(1 \mathrm{~cm})$ long.

\section{Siliceous Assemblage}

The siliceous assemblage includes laminated to thinbedded generally black chert and shale and gray and white mottled quartzite. The shale, especially below the thrust at the north end of the window, has been altered to a multicolored unconsolidated gouge and breccia. The chert at the north end of the window is partly recrystallized to a black, gray, white, and lightbrown fine- to medium-grained quartzite with numerous white quartz veins. Generally, the quartz in the veins is very fine grained although in some of these veins the grains of quartz are as much as $1 \mathrm{~cm}$ long. Cavities as much as $5 \mathrm{~cm}$ across occur between quartz veins.

The chert and shale around the window are continuous with early and middle Paleozoic rocks of the siliceous assemblage in the northern Rodeo Creek NE quadrangle (Evans, 1974a). No fossils were found in the siliceous assemblage in the Bootstrap area, but Ordovician and Silurian graptolites were found in the shale in the Rodeo Creek NE quadrangle. The siliceous rocks around the Bootstrap window, therefore, are probably early and middle Paleozoic in age and may be partly correlative with the Vinini Formation.

\section{Overlap Assemblage}

Although rocks of the overlap assemblage (postAntler Paleozoic sedimentary rocks) are not exposed in the Bootstrap window, these rocks probably once 

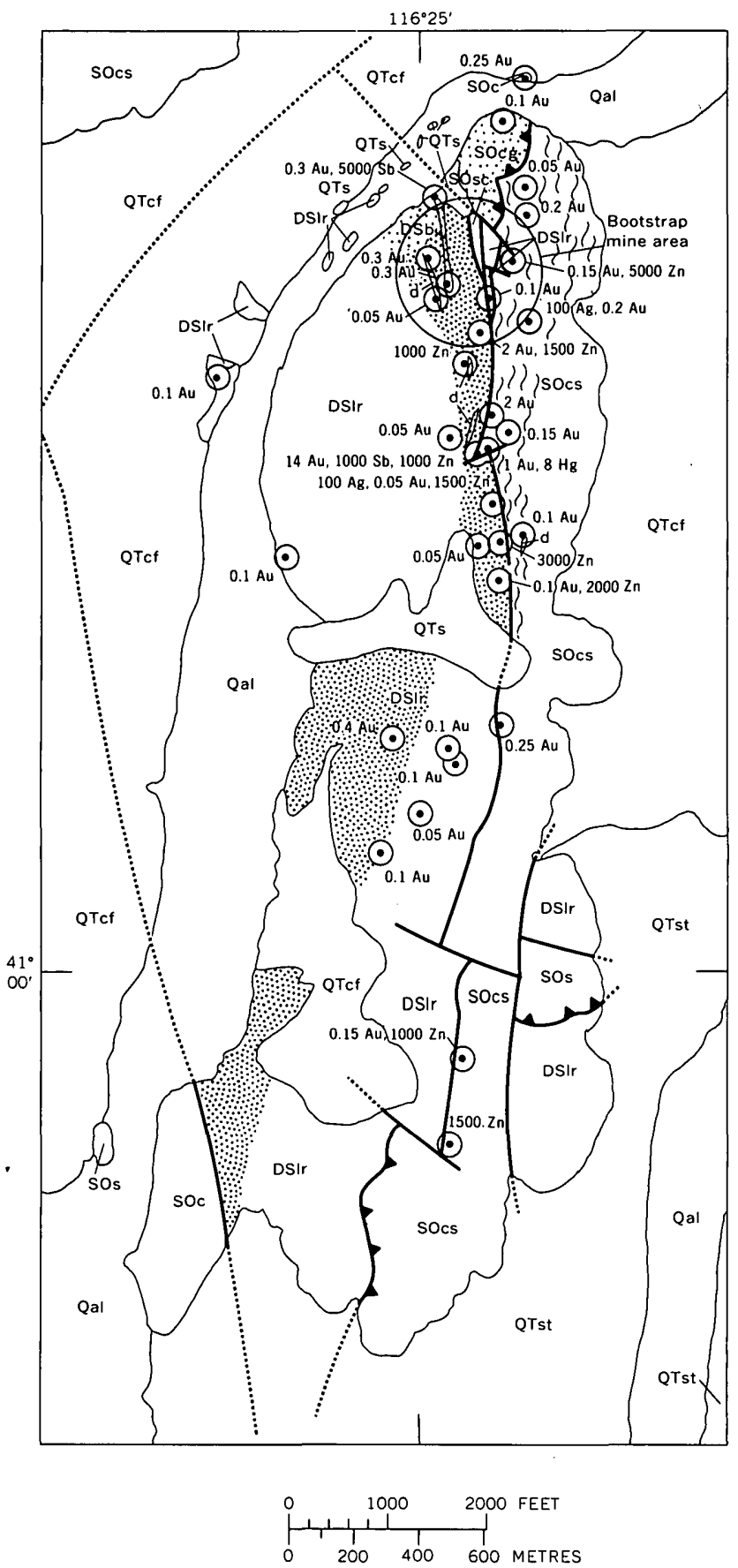

EXPLANATION

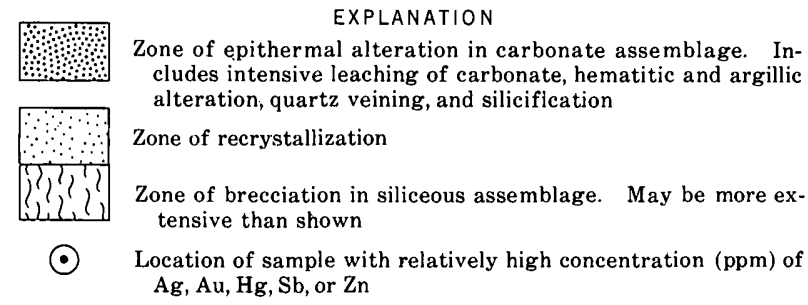

Figure 3.-Map showing zones of epithermal alteration, recrystallization, and brecciation, and distribution of elements in Bootstrap window. Large circle, Bootstrap mine area. See figure 2 for explanation of geology. occurred nearby. At the northern end of the window, an isolated rounded boulder of chert pebble conglomerate about $6 \mathrm{ft}(1.8 \mathrm{~m})$ in diameter occurs in a creek bed. The chert pebble conglomerate is similar to the post-Antler conglomerates in Elko County (R. R. Coats, written commun., 1974). The chert pebbles are white and gray and subrounded to well rounded and range in diameter from one-fourth inch $(6.2 \mathrm{~mm})$ to 6 in. $(15 \mathrm{~cm})$ with the smaller sizes predominating. The pebbles are in a matrix of coarse sand that is also composed of chert fragments and is cemented by chert.

\section{Altered Dikes}

Steeply dipping dikes that trend generally northsouth and range from $1 \mathrm{ft}(30 \mathrm{~cm})$ to $80 \mathrm{ft}(24.4 \mathrm{~m})$ wide (widest dike exposed only in a trench) intrude the Paleozoic rocks. These dikes may represent more than one compositional type, and they have undergone different kinds and degrees of alteration.

The most common dikes consist of brown, light-gray, and black rocks that contain euhedral phenocrysts that form as much as half of the rock and are as much as $3 \mathrm{~mm}$ long. These phenocrysts are intensely sericitized and, locally, saussuritized. The groundmass consists largely of anhedral plagioclase grains $0.1-0.3 \mathrm{~mm}$ in diameter. Quartz is present in amounts less than 10 percent. Mafic silicate minerals are not commonly preserved, although scattered biotite and sphene can be identified in a few of the dikes. These dikes contain abundant dark-brown and black spots that are aggregates of jarosite and hematite.

These dikes resemble granodiorite dikes in the northern part of the Lynn window, not far from the Gold Strike plug, $4 \mathrm{mi}(6.4 \mathrm{~km})$ southeast of the Bootstrap window (fig. 11). The dikes near the plug are similar in composition to the plug and were correlated with it (Evans, 1974a). The Gold Strike plug is of Early Cretaceous age (Hausen and Kerr, 1968), and the dikes in the Bootstrap area may be the same age.

Less common dikes are mottled creamy white to light-gray and as much as $3 \mathrm{ft}(1 \mathrm{~m})$ wide. These dikes are soft and generally exposed only in the exploration pits and roadcuts. The dikes contain black-, brown-, yellow-, and red-stained altered zones. The freshest samples have white feldspar phenocrysts as much as $2 \mathrm{~mm}$ long set in a light-gray extremely fine grained to aphanitic groundmass.

\section{Tertiary and (or) Quaternary Rocks}

\section{Siltstone and tuff}

A siltstone and tuff unit lies on the Paleozoic rocks south and southeast of the window and is continuous 
with the dissected valley fill in Little Boulder Basin. These rocks form few outcrops and weather to a buff clay and silty soil. The only outcrop near the Bootstrap window is in an exploration pit on the east side of the window and is shown by an attitude on the map (fig. 2). The rocks there are thin- to thick-bedded white and buff siltstone, friable tuffaceous siltstone, light-gray tuff, and thin pale-yellow beds of silicacemented siltstone.

\section{Chert fanglomerate}

Unconsolidated chert fanglomerate, possibly a few tens of metres in maximum thickness, underlies the hills to the west of Boulder Creek, the headwaters of Bell Creek, and covers part of the carbonate assemblage in the Bootstrap window. The chert fragments are angular, as much as several centimetres long, and are in a light-brown-gray matrix of silt and fine sand. Locally, boulders as much as $8 \mathrm{ft}(2.6 \mathrm{~m})$ long occur in the fanglomerate. The pervasive occurrence of chert clasts over much of the carbonate rocks suggests that at least the southern and lower part of the window was originally covered by the fanglomerate. The relation between the fanglomerate and the siltstone and tuff described above is not clear. Possibly the fanglomerate overlies the siltstone and tuff as well as the Paleozoic rocks and is the younger deposit.

\section{Siltstone}

Variegated siltstone containing minor beds of conglomerate is exposed in three localities.

In a gulley at the north end of the window, poorly lithified, light-brown, creamy-white, violet, and pink siltstone, containing sand-sized fragments of siltstone, is overlain by unconsolidated conglomerate composed of angular fragments of silty laminated limestone and chert. The conglomerate grades upwards into brown soil with angular chert and quartzite boulders as much as $2 \mathrm{ft}(0.65 \mathrm{~m})$ across.

Thin-bedded to laminated, poorly lithified to wellcemented, white, pink, green, intensely fractured siliceous siltstone forms small outcrops in the bed of Boulder Creek, below the stream gravels, near the north end of the window.

The largest deposit is on the west side of the window about $3,000 \mathrm{ft}(980 \mathrm{~m})$ south of the Bootstrap mine. This deposit contains three principal rock types: (1) angular chert pebble and cobble conglomerate having a red silt and clay matrix; (2) white and pink siltstone having sand-sized particles of altered Paleozoic siltstone and a few chert pebbles $1 \mathrm{in} .(2.5 \mathrm{~cm})$ long; and (3) an uppermost fanglomerate $2-3 \mathrm{ft}(0.65-1 \mathrm{~m})$ thick, consisting of angular cobbles of limestone, chert, quartzite, and siltstone (Paleozoic lithologies) as much as 1 in. $(2.5 \mathrm{~cm})$ across in a brown silt and clay matrix.

The age relations of the siltstone, although clearly post-Paleozoic and older than the Quaternary alluvium and possibly the chert fanglomerate, are not clear.

\section{Quaternary Alluvium}

Alluvium of Quaternary age in the area consists of the terrace deposits along Boulder and Bell Creeks and the stream gravels within the channels. The terraces are composed of subrounded and rounded unconsolidated boulder and cobble conglomerate composed of chert, quartzite, and chert breccia clasts in a brown sandy and silty matrix. The clasts range in size from 1 in. $(2.5 \mathrm{~cm})$ to $2 \mathrm{ft}(0.65 \mathrm{~m})$ across but are generally less than 6 in. $(15 \mathrm{~cm})$ long. In places along the top of the conglomerate, fine soil has accumulated in marshy depressions in the flood plain of Boulder Creek. The stream gravels are virtually the same composition as the terrace deposits but have a coarser grained matrix.

\section{STRUCTURAL GEOLOGY}

Most of the southern part of Bootstrap window consists of a north-trending graben of siliceous assemblage rocks lying between blocks of carbonate rocks (fig. 2, $\left.B-B^{\prime}\right)$. Probably the graben continues northward beneath Tertiary and Quaternary rocks, but only the west side of the graben is exposed. The main faults bounding the graben trend north and are generally steep. These faults are offset by minor steep faults trending principally west-northwest. Segments of thrust faults are present at the north and south ends of the window. The two southern ones are contacts between the siliceous and carbonate assemblage. One of them appears to be the southern extension of the steep fault on the west side of the graben. The thrust fault at the northern end is within rocks of the siliceous assemblage and places chert and quartzite on chert. Whether any of these thrust faults are segments of a larger regional thrust, like the Roberts Mountains thrust, is not known.

\section{ECONOMIC GEOLOGY}

Development at the Bootstrap mine area in this century was along a complex 600 -ft (184-m) -wide steeply dipping fault zone at the north end of the window (fig. 3). The gold ore came principally from an altered porphyry dike. Total production of gold through November 1959 was $\$ 330,532$. Antimony ore was also 
mined and hauled to Dunphy in 1914 but was not shipped (Lawrence, 1963, p. 58).

Recent interest in the Bootstrap mine area arose from the similarities between the altered and mineralized limestone there and the limestone at the Carlin gold mine. The Carlin Gold Mine Co. controls the mining claims in the Bootstrap window and has investigated the gold potential of the area; the conclusion of these studies has not been released. However, a lowgrade gold ore body is being mined by open pit methods at the north end of the window. The ore body at the Bootstrap mine and at the Blue Star mine, $8 \mathrm{mi}$ $(13 \mathrm{~km})$ southeast of the Bootstrap window, together are estimated at 1.1 million tons averaging less than 0.297 ounces of gold per ton (West, 1974, p. 572).

A summary of the major findings based on the results of spectrographic and atomic absorption ( $\mathrm{Au}$, $\mathrm{Hg}$ ) analyses for surface rock samples collected from the Bootstrap window (Evans, 1974b) is given below and shown in figure 3.

Samples of rock with at least 1 ppm gold (max 14 $\mathrm{ppm}$ ) were collected from the siliceous assemblage south of the old mine workings along the steep northtrending fault zone on the west side of the graben. Samples with gold values $\geqq 0.05 \mathrm{ppm}$ (maximum 0.4 ppm) were taken from several localities in the limestone. Concentrations of silver and mercury $>0.5 \mathrm{ppm}$ are common and widespread in the Bootstrap area, although the greatest values of these two elements ( $\mathrm{Ag}$ maximum $100 \mathrm{ppm}$; $\mathrm{Hg}$ maximum $8 \mathrm{ppm}$ ) were in samples from near the north-south fault on the west side of the graben. Concentrations of antimony and zinc $\geqq 1,000 \mathrm{ppm}$ (Sb maximum $5,000 \mathrm{ppm}$; Zn maximum $5,000 \mathrm{ppm}$ ) occur in samples in the vicinity of the same fault. Most of the high values of zinc are in samples from the siliceous assemblage.

\section{REFERENCES CITED}

Evans, J. G., 1974a, Geologic map of the Rodeo Creek NE quadrangle, Eureka County, Nevada: U.S. Geol. Survey Geol. Quad. Map GQ-1116.

1974b, Bootstrap Window, Elko and Eureka Counties, Nevada-Geological summary and analyses of rock samples: U.S. Geol. Survey open-flle rept. (74-369).

Hausen, D. M., and Kerr, P. F., 1968, Fine gold occurrence at Carlin, Nevada, in Ridge, J. D., ed., Ore deposits of the United States, 1933-1967, (Graton-Sales, v. 1) : New York, Am. Inst. Mining Metall. and Petroleum Engineers, Inc., p. $908-940$.

Lawrence, E. F., 1963, Antimony deposits of Nevada: Nevada Bur. Mines Bull. 61, 248 p.

McKee, E. H., and Silberman, M. L., 1970, Geochronology of Teritary igneous rocks in central Nevada: Geol. Soc. America Bull., v. 81, p. 2317-2328.

Roberts, R. J., Montgomery, K. M., and Lehner, R. E., 1967, Geology and mineral resources of Eureka County, Nevada: Nevada Bur. Mines Bull. 64, 152 p.

Stewart, J. H., and Poole, F. G., 1974, Lower Paleozoic and uppermost pre-Cambrian Cordilleran miogeocline, Great Basin, Western United States, in Dickinson, W. R., ed., Tectonics and sedimentation, a symposium: Soc. Econ. Paleontologist and Mineralogists Spec. Pub. 22. (In press.)

West, J. M., 1974, Gold: U.S. Bur. Mines Minerals Yearbook 1972 , v. 1 , p. $567-588$. 


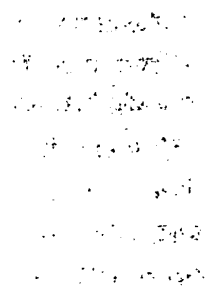




\section{RECENT PUBLICATIONS OF THE U.S. GEOLOGICAL SURVEY}

(The following books may be ordered from the Branch of Distribution, U.S. Geological Survey, 1200 South Eads Street Arlington, VA 22202 (an authorized agent of the Superintendent of Documents, Government Printing Office). Prepayment is required. Remittances should be sent by check or money order payable to U.S. Geological Survey. Give series designation and number, such as Bulletin 1368-A, and the full title. Prices of Government publications are subject to change. Increases in costs make it necessary for the Superintendent of Documents to increase the selling prices of many publications offered. $\Lambda$ s it is not feasible for the Superintendent of Documents to correct the prices manually in all the previous announcements and publications stocked, the prices charged on your order may differ from the prices printed in the announcements and publications)

\section{Professional Papers}

433-0. Distribution of radionuclides in the Columbia River streambed, Hanford Reservation to Longview, Wash., by W. L. Haushild, G. R. Dempster, Jr., and H. H. Stevens, Jr. 1975. p. O1-035. \$1.20.

437-H. Land subsidence in the San Joaquin Valley, Calif., as of 1972, by J. F. Poland, B. E. Lofgren, R. L. Ireland, and R. G. Pugh. 1975. p. H1-H78. $\$ 2.20$.

502-C. Solute balance at Abert and Summer Lakes, southcentral Oregon, by A. S. Van Denburgh. 1975; p. C1-C29; plate in pocket. $\$ 2.35$.

798-B. Geology and geochemistry of the Copper Canyon porphyry copper deposit and surrounding area, Lander County, Nev., by T. G. Theodore and D. W. Blake. 1975. p. B1-B86 ; plates in pocket. $\$ 3.50$.

813-B. Summary appraisals of the Nation's ground-water resources-Upper Mississippi Region, by R. M. Bloyd, Jr. 1975. p. B1-B22. 30द.

827. Gealogy of the Sierra Foothills Mélange and adjacent areas, Amador County, Calif., by W: A. Duffield and $\mathbf{R}$. V. Sharp. $1975.30 \mathrm{p}$.; plate in pocket. $\$ 2.35$.

835. Quaternary geology of Alaska, by T. L. Péwé. 1975. 145 p. ; plates in pocket. $\$ 3.40$.

836. Stratigraphic distribution and zonation of Jurassic (Callovian) ammonites in southern Alaska, by R. W. Imlay. 1975.28 p.; 6 plates showing fossils. $\$ 1.55$.

848-B. Carboniferous Foraminifera and algae of the Amsden Formation (Mississippian and Pennsylvanian) of Wyoming, by B. L. Mamet. 1975. p. B1-B18; 2 plates showing fossils. \$1.

848-C. Coelenterata of the Amsden Formation (Mississippian and Pennsylvanian) of Wyoming, by W. J. Sando. 1975. p. C1-C31; 10 plates showing fossils. $\$ 1.55$.

848-E. Pelecypoda and Rostroconchia of the Amsden Formation (Mississippian and Pennsylvanian) of Wyoming, by MacKenzie Gordon, Jr., and John Pojeta, Jr. 1975. p. E1E24; 4 plates showing fossils. \$1.35.

848-F. Gastropoda, Cephalopoda, and Trilobita of the Amsden Formation (Mississippian and Pennsylvanian) of Wyoming, by MacKenzie Gordon, Jr., and E. L. Yochelson. 1975. p. F1-F30; 2 plates showing fossils. $\$ 1.35$

848-G. Mississippian Ostracoda of the Amsden Formation (Mississippian and Pennsylvanian) of Wyoming, by I. G. Sohn. 1975. p. G1-G22; 3 plates showing fossils. $\$ 1.15$.

861. Chesapecten, a new genus of Pectinidae (Mollusca: Bivalvia) from the Miocene and Pliocene of eastern North America, by L. W. Ward and B. W. Blackwelder, 1975. 24 p.; 10 plates showing fossils. $\$ 1.45$.

864-A. A review and interpretation of the geologic setting of the Watchung Basalt flows, New Jersey, by G. T. Faust. 1975. p. A1-A42. \$1.55.

871. Lithology and origin of Middle Ordovician calcareous mudmound at Meiklejohn Peak, southern Nevada, by $R$. J. Ross, Jr., Valdar Jaanusson, and Irving Friedman. 1975. 48 p. $\$ 1.60$.
876. Cauldron subsidence of Oligocene age at Mount Lewls, northern Shoshone Range, Nev., by C. T. Wrucke and $M$. L. Silberman. 1975.20 p. $85 \phi$.

878. Evaluation of ground-water degradation resulting from waste disposal to alluvium near Barstow, Calif., by J. L. Hughes, 1975. 33 p. $\$ 1.20$

886. Post-Carboniferous stratigraphy, northeastern Alaska, by R. L. Detterman, H. N. Reiser, W. P. Brosgé, and J. T. Dutro, Jr. 1975.46 p. $\$ 1.40$.

888. Tectonic studies of the Berkshire massif, western Massachusetts. Connecticut, and Vermont. Chap. A-G. 1975. 103 p. $\$ 2.90$

918. Lithium in unconsolidated sediments and plants of the Basin and Range province, southern California and $\mathrm{Ne}$ vada, by H. L. Cannon, T. F. Harms, and J. C. Hamilton. 1975. 23 p. $\$ 1.10$.

925. Sedimentation and tectonics in the early Tertiary continental borderland of central California, by T. H. Nilsen and S. H. Clarke, Jr. 1975 . 64 p. $\$ 1.70$

930. A hydrologic assessment of the September 14, 1974, flood in Eldorado Canyon, Nev., by P. A. Glancy and Lynn Harmsen. 1975. 28 p. \$1.15.

\section{Bulletins}

1317-C. Some peat deposits in Washington and southeastern Aroostook Counties, Maine, by C. C. Cameron. 1975. p. C1C40. $70 \phi$.

1384. Aeromagnetic and limited gravity studies and generalized geology of the Bodie Hills region, Nevada and Callfornia, by F. J. Kleinhampl, W. E. Davis, M. L. Silberman, C. W. Chesterman, R. H. Chapman, and C. H. Gray, Jr. 1975 . $38 \mathrm{p}$.; plate in pocket. $\$ 1.25$.

1391-B. Mineral resources of the Absaroka Primitive Area and vicinity, Park and Sweet Grass Counties, Mont., by Helmuth Wedow, Jr., D. L. Gaskill, D. P. Banister, and E. C. Pattee; with a section on Interpretation of geophysical data, by D. L. Peterson. 1975. p. B1-B115; plates in pocket. \$3.45.

1391-C. Mineral resources of the Clear Creek-Upper Big Deer Creek study area, contiguous to the Idaho Primitive Area, Lemhi County, Idaho, by F. W. Cater, D. M. Pinckney, and R. B. Stotelmeyer. 1975. p. C1-C41. 80

1409. A summary of oil and gas production and reserve histories of the Appalachian basin, 1859-1972, by B. M. Miller. 1975.36 p. $70 \phi$.

\section{Water-Supply Papers}

1608-0. Reclamation by tubewell drainage in Rechna Doāb and adjacent areas, Punjab region, Pakistan, by G. T. Malmberg. 1975. p. O1-072; plates in separate case. $\$ 1.15$. 2036. Digital-simulation and projection of water-level declines in basalt aquifers of the Odessa-Lind area, east-central Washington, by J. E. Luzier and J. A. Skrivan. 1975. 48 p. $75 \phi$ 
U.S. GOVERNMENT

PRINTING OFFICE

PUBLIC DOCUMENTS DEPARTMENT

WASHINGTON, D.C. 20402

OFFICIAL BUSINESS

PENALTY FOR PRIVATE USE $\$ 300$
POSTAGE AND FEES PAID U.S. GOVERNMENT PRINTING OFFICE 375

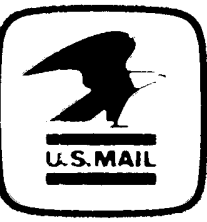

Special

fourth-class rate books 